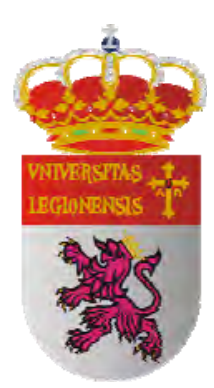

UNIVERSIDAD DE LEÓN

Facultad de Ciencias Biológicas y Ambientales

\title{
IMAGING SPECTROSCOPY TO EVALUATE THE CONTAMINATION FROM SULPHIDE MINE WASTE IN THE IBERIAN PYRITE BELT USING HYPERSPECTRAL SENSORS (HUELVA, SPAIN)
}

\section{ESPECTROSCOPÍA DE IMÁGENES PARA LA EVALUACIÓN DE CONTAMINACIÓN RELACIONADA CON MINAS DE SULFUROS EN LA FAJ A PIRÍTICA IBÉRICA MEDIANTE SENSORES HIPERESPECTRALES (PROVINCIA DE HUELVA)}

\author{
TESIS DOCTORAL \\ J orge Buzzi Marcos \\ Directores: Dra. Asunción Riaza García \\ Dr. Eduardo García-Meléndez
}

León, 1 octubre 2012

Programa de Doctorado “Geología Ambiental y Aplicada. Recursos y Riesgos Geológicos" 



\section{AGRADECIMIENTOS}

Han sido muchas las personas que han estado a mi lado a lo largo de estos años. Quiero dar las gracias a todos los que me han ayudado incondicionalmente.

Mis directores de Tesis, Asunción Riaza y Eduardo García-Meléndez, en el IGME y la Universidad de León respectivamente, me han guiado pacientemente a lo largo de todo este proceso. Gracias a ellos me adentré en el conocimiento de la Faja Pirítica, la problemática de la contaminación por las aguas ácidas y las posibilidades que ofrece la espectroscopía de imágenes para el estudio de este medio. Su conocimiento y continuas aportaciones y sugerencias han sido imprescindibles para que este trabajo tenga la calidad que se merece.

Esta Tesis ha sido financiada mediante una ayuda FPI del Subprograma de Formación de Personal Investigador (BES-2008-003648) y por el proyecto CGL2007-60004/CLI del Plan Nacional de Investigación. El Subprograma FPI también me ha financiado dos estancias breves en centros europeos de investigación (SEST1000I001495XVO), en la Agencia Aeroespacial Alemana (DLR, Deutches Zentrum für Luft- und Raumfahrt) de Múnich (EST2009010937) y en el Laboratorio de Planetología y Geodinámica de Nantes (LPGN, Laboratoire de Plánetologie et Géodynamique de Nantes), en Francia (EEBB-I-2010-01495).

Las estancias breves realizadas han supuesto una experiencia sumamente enriquecedora, tanto profesional como personal. En Múnich, Andreas Müller y su equipo del DLR me recibieron con los brazos abiertos; con Rolf Richter y Martin Bachmann me adentré en los entresijos de las correcciones atmosféricas y topográficas de las imágenes hiperespectrales. Con ellos y el resto de compañeros (Sebastian, Anita, Jordi, Nicole...) descubrí lo mejor de Baviera. Gracias a vosotros el invierno bávaro no fue tan frío.

Gracias a Véronique Carrère y al resto de la gente del Laboratoire de Plánetologie et Géodynamique de Nantes, que me acogieron muy amablemente en esta bella ciudad francesa, conocí las posibilidades que la modelización Gaussiana podía aportar a mi zona de estudio. La compañía de Aurore, Farzaneh, Erwin, Gaëlle, Katya, Olivia y muchos más fue muy importante. 
Durante el tiempo que he pasado en Madrid y en Tres Cantos, los compañeros de las diferentes oficinas del IGME han hecho que me sintiera como en casa. Muchos de ellos están enfrascados en sus Tesis o las han finalizado recientemente, saben muy bien el esfuerzo que supone. Javi, María, Nacho, Maider, Juan, Enrique, Aida, Santos... es imposible mencionaros a todos. Muchas gracias, chicos.

Parte de los análisis químicos y de DRX fueron realizados en los laboratorios del IGME. Es de agradecer su dedicación y profesionalidad. Asimismo, mi gratitud al personal que ha gestionado los farragosos trámites de viajes a congresos y salidas de campo. Los técnicos de informática también me sacaron de más de un apuro.

Ha existido una buena relación con la facultad de Geología de la Universidad de Huelva. Ha habido un intercambio de información muy fructífero que ha permitido avanzar en el conocimiento del río Odiel. En sus laboratorios también se realizaron análisis químicos y de DRX, que proporcionaron una muy valiosa información. La Junta de Andalucía tramitó amablemente los permisos necesarios para acceder a las explotaciones mineras. La gente de los pueblos de la rivera del Odiel facilitó mucho el trabajo cuando fue necesario. Tampoco puedo olvidarme de los investigadores con quienes he compartido trabajo de campo, como Jamshid, Lily y Andreas.

No puedo dejarme en el tintero a mis amigos: Pedro, Chusa, Isa, Mão, Conchy, Susana, Harry... vuestra amistad, aderezada con escaladas, cervezas y ganas de cambiar el mundo me ha dado fuerzas para superar todas las dificultades que se me han ido presentando.

Sin duda alguna mi familia, mis padres y mi hermana, se merecen todo mi agradecimiento por su apoyo incondicional y consejos que siempre me han dado. Os lo debo todo. 


\section{TABLE OF CONTENTS}

\section{IMAGING SPECTROSCOPY TO MONITOR THE CONTAMINATION FROM SULPHIDE MINE WASTE IN THE IBERIAN PYRITE BELT USING HYPERSPECTRAL SENSORS (HUELVA, SPAIN)}

Jorge Buzzi Marcos

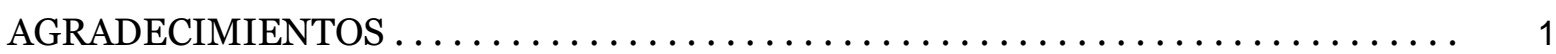

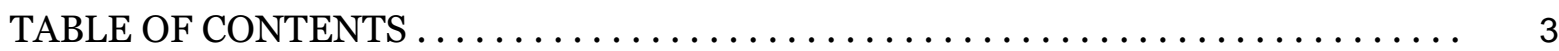

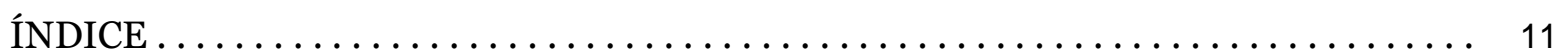

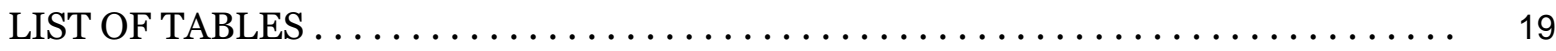

LIST OF FIGURES $\ldots \ldots \ldots \ldots \ldots \ldots \ldots \ldots \ldots \ldots \ldots \ldots \ldots \ldots \ldots \ldots \ldots \ldots \ldots \ldots \ldots, 20$

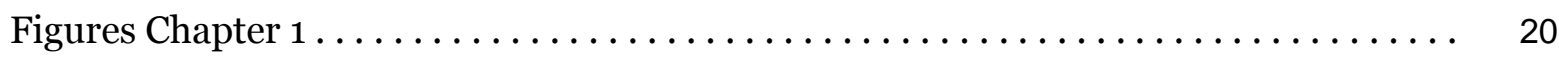

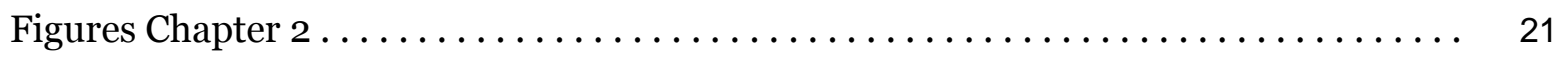

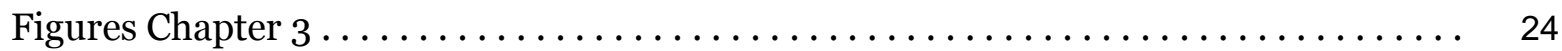

Figures Chapter $4 \ldots \ldots \ldots \ldots \ldots \ldots \ldots \ldots \ldots \ldots \ldots \ldots \ldots \ldots \ldots \ldots \ldots \ldots \ldots \ldots \ldots \ldots, 28$

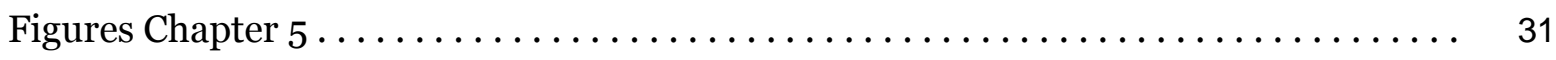

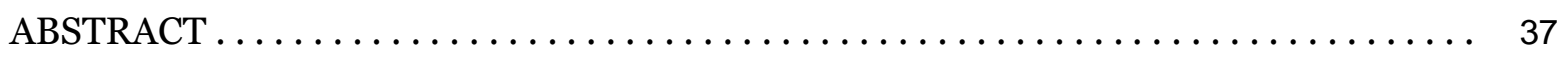

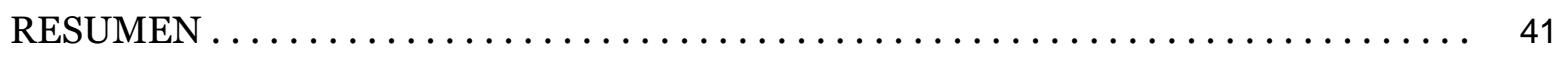

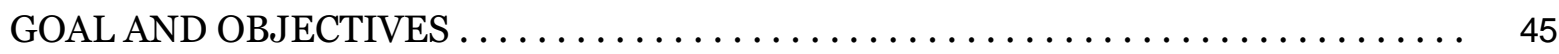

CHAPTER 1. MINE TAILINGS AND ACID MINE DRAINAGE UNDER AN IMAGING SPECTROSCOPY VIEW: STATE OF THE ART $\ldots \ldots \ldots \ldots \ldots \ldots \ldots \ldots \ldots \ldots, 47$

1.1. Introduction $\ldots \ldots \ldots \ldots \ldots \ldots \ldots \ldots \ldots \ldots \ldots \ldots \ldots \ldots \ldots \ldots \ldots \ldots \ldots \ldots, 47$

1.2. The hyperspectral monitoring tool $\ldots \ldots \ldots \ldots \ldots \ldots \ldots \ldots \ldots \ldots \ldots \ldots, 48$

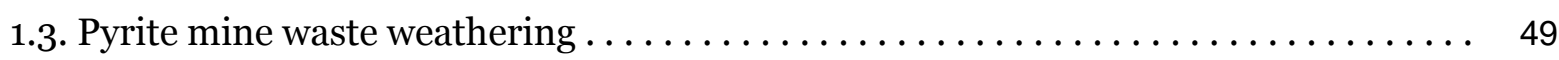




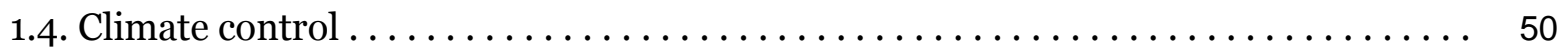

1.5. Regional geology and climate $\ldots \ldots \ldots \ldots \ldots \ldots \ldots \ldots \ldots \ldots \ldots \ldots \ldots \ldots \ldots \ldots \ldots \ldots \ldots$

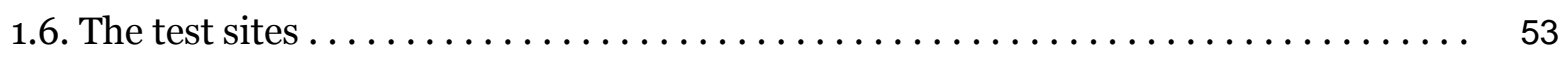

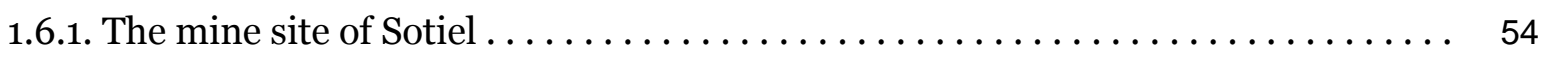

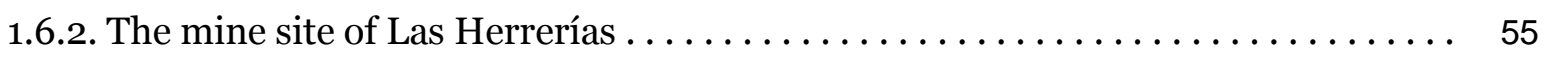

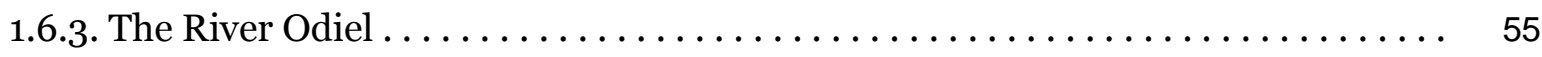

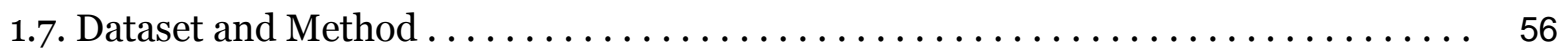

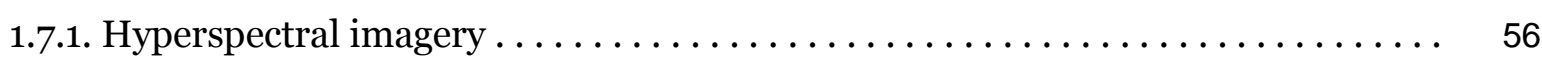

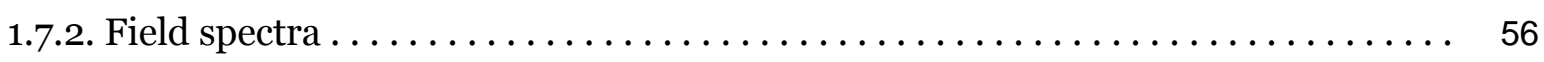

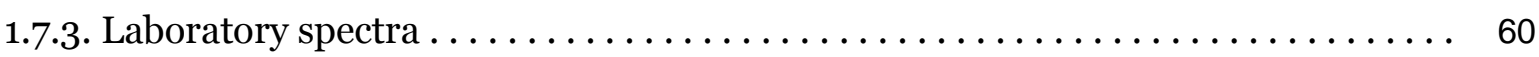

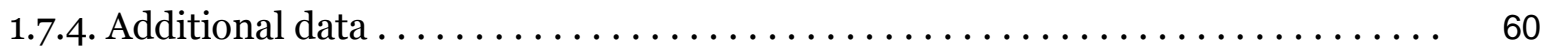

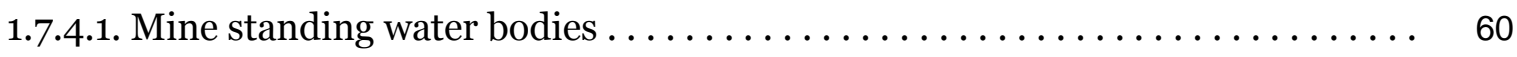

1.7.4.2. River flowing water $\ldots \ldots \ldots \ldots \ldots \ldots \ldots \ldots \ldots \ldots \ldots \ldots \ldots \ldots \ldots \ldots \ldots \ldots \ldots \ldots$

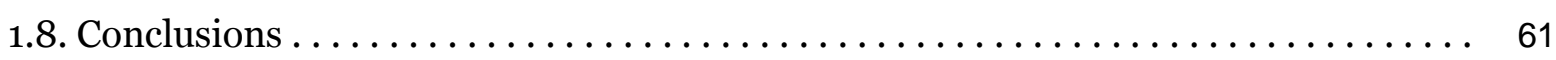

CHAPTER 2. MAPPING THROUGH IMAGE PROCESSING $\ldots \ldots \ldots \ldots \ldots \ldots \ldots .63$

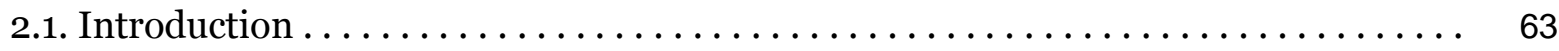

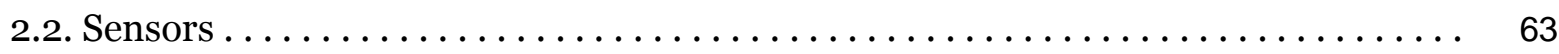

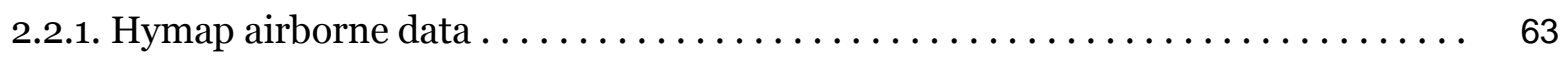

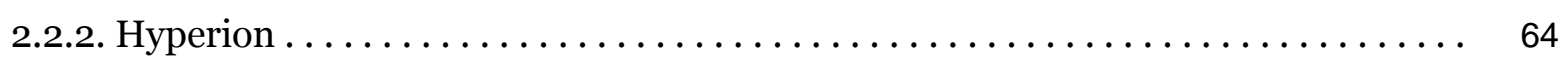

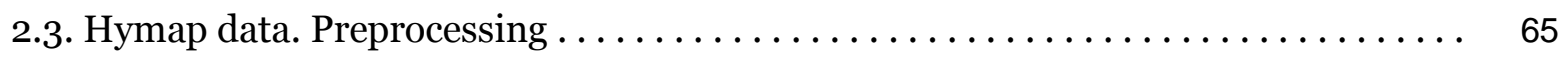

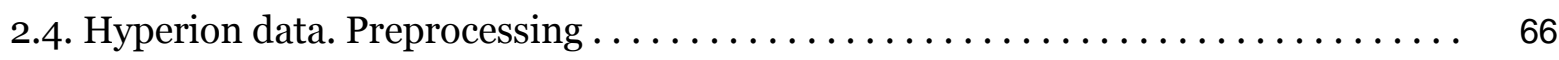

2.5. Hyperspectral image processing sequence $\ldots \ldots \ldots \ldots \ldots \ldots \ldots \ldots \ldots \ldots$

2.6. Using reference spectral libraries $\ldots \ldots \ldots \ldots \ldots \ldots \ldots \ldots \ldots \ldots \ldots \ldots \ldots$

2.7. Image processing to map the contamination on mine waste $\ldots \ldots \ldots \ldots \ldots \ldots$

2.8. Image processing to map the contamination on the river $\ldots \ldots \ldots \ldots \ldots \ldots \ldots \quad 74$

2.9. Automated Modified Gaussian Model: a new exploration method .......... 76

2.9.1. Evaluation of parameters from Spectroscopic Derivative Analysis on Hymap spectra from contaminated river sediments $\ldots \ldots \ldots \ldots \ldots \ldots \ldots \ldots \ldots \ldots \ldots$ 
2.10. Conclusions

CHAPTER 3. MAPPING PYRITE WEATHERING PRODUCTS OVER A RECOVERING MINE SITE WITH HYPERSPECTRAL AIRBORNE HYMAP DATA (SOTIEL, HUELVA, SW SPAIN) . . . . . . . . . . . . . . . . . . . . . . .

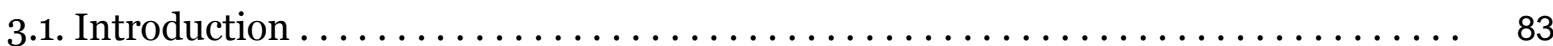

3.2. The influence of climate $\ldots \ldots \ldots \ldots \ldots \ldots \ldots \ldots \ldots \ldots \ldots \ldots \ldots \ldots \ldots \ldots$

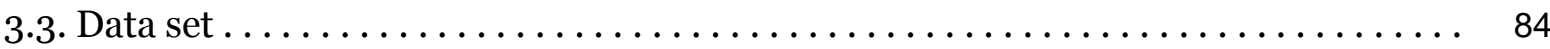

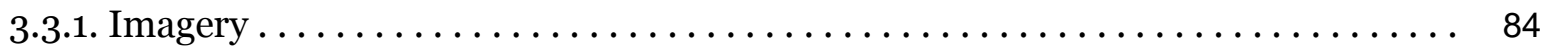

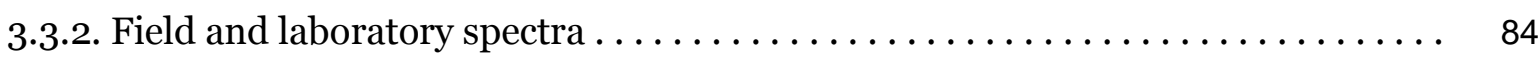

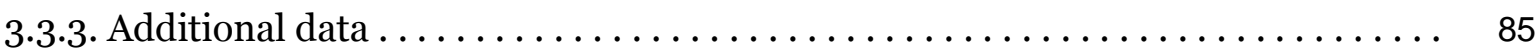

3.4. The mine site facilities in Sotiel $\ldots \ldots \ldots \ldots \ldots \ldots \ldots \ldots \ldots \ldots \ldots \ldots \ldots \ldots \ldots \ldots \ldots \ldots \ldots$

3.5. Change detection 2005-2008-2009 in the Sotiel mine site $\ldots \ldots \ldots \ldots \ldots \ldots . \quad 87$

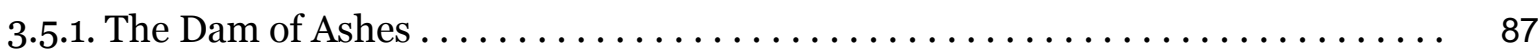

3.5.2. The mine dumps by the river $\ldots \ldots \ldots \ldots \ldots \ldots \ldots \ldots \ldots \ldots \ldots \ldots \ldots \ldots \ldots \ldots \ldots \ldots$

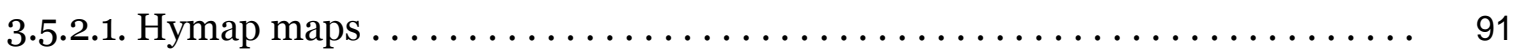

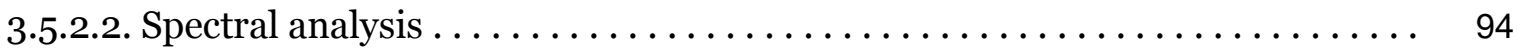

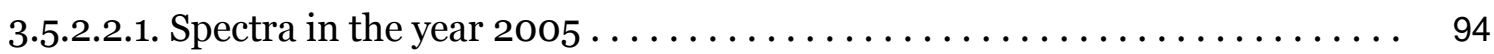

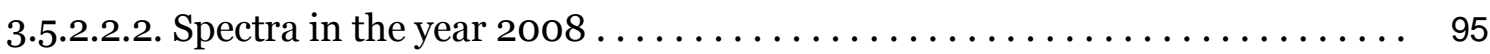

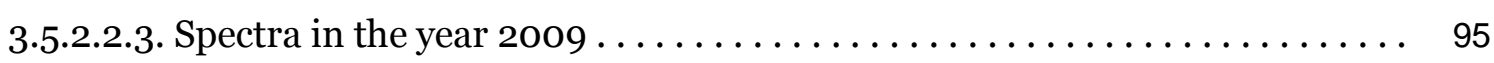

3.5.3. The mill tailings dam $\ldots \ldots \ldots \ldots \ldots \ldots \ldots \ldots \ldots \ldots \ldots \ldots \ldots \ldots \ldots \ldots \ldots$

3.5.3.1. Hymap maps $\ldots \ldots \ldots \ldots \ldots \ldots \ldots \ldots \ldots \ldots \ldots \ldots \ldots \ldots \ldots \ldots \ldots \ldots \ldots$

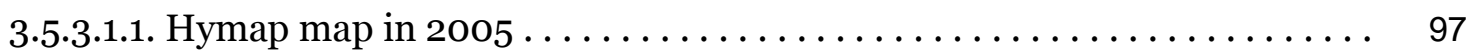

3.5.3.1.2. Hymap map in $2008 \ldots \ldots \ldots \ldots \ldots \ldots \ldots \ldots \ldots \ldots \ldots \ldots \ldots$

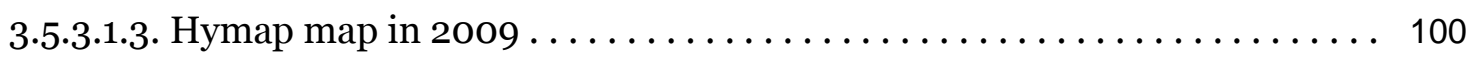

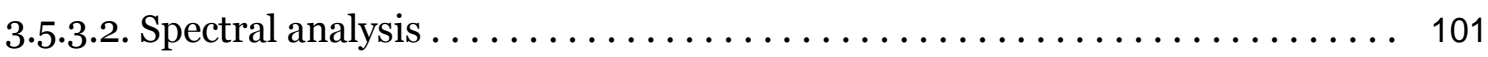

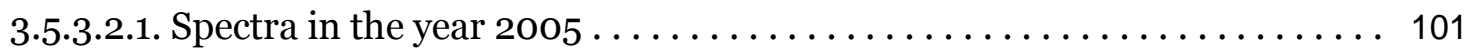

3.5.3.2.2. Spectra in the year $2008 \ldots \ldots \ldots \ldots \ldots \ldots \ldots \ldots \ldots \ldots \ldots \ldots \ldots \ldots \ldots$

3.5.3.2.3. Spectra in the year $2009 \ldots \ldots \ldots \ldots \ldots \ldots \ldots \ldots \ldots \ldots \ldots \ldots \ldots$ 
3.5.4. The ore processing plant and neighbourhood $\ldots \ldots \ldots \ldots \ldots \ldots \ldots \ldots$

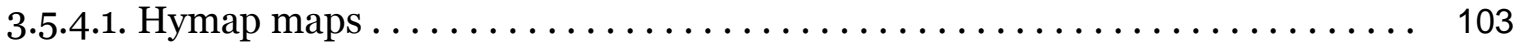

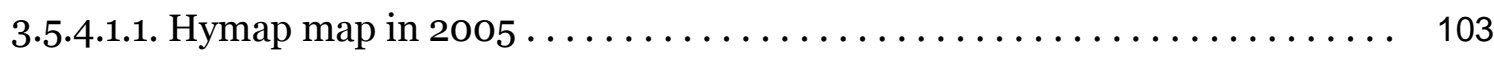

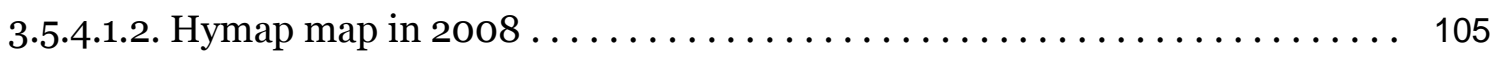

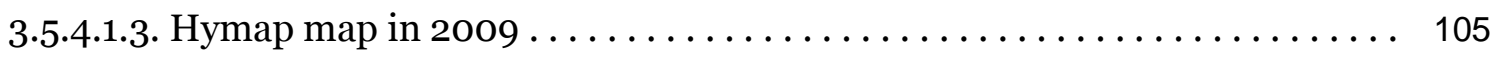

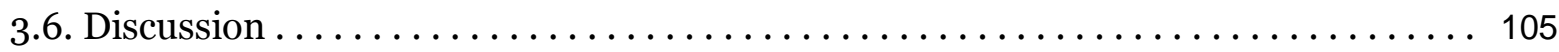

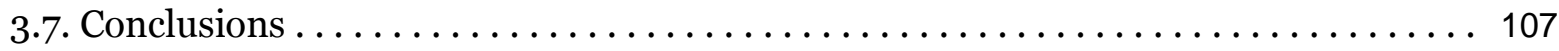

CHAPTER 4. MAPING IRON SULPHIDE MINE SITE ON WASTE AND WATER USING AIRBORNE HYMAP AND SPACEBORNE HYPERION HYPERSPECTRAL

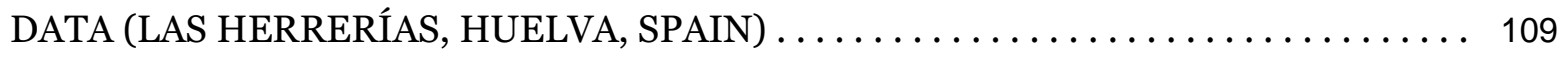

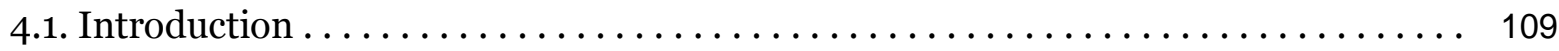

4.2. Spectral features of pyrite mine waste, acid mine drainages and mine waste ponds 111

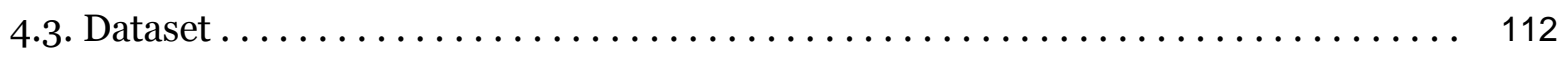

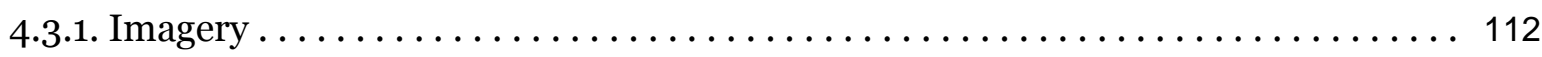

4.3.2. Geological ground and laboratory survey $\ldots \ldots \ldots \ldots \ldots \ldots \ldots \ldots \ldots \ldots \ldots$

4. 4. Mapping through image processing $\ldots \ldots \ldots \ldots \ldots \ldots \ldots \ldots \ldots \ldots \ldots \ldots \ldots \ldots \ldots \ldots \ldots \ldots$

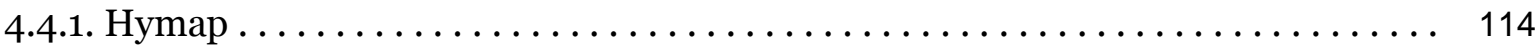

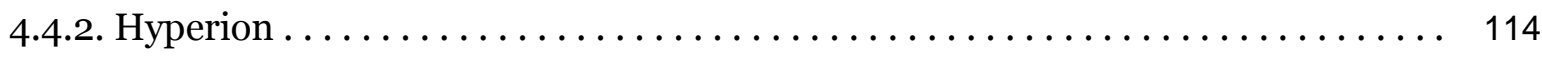

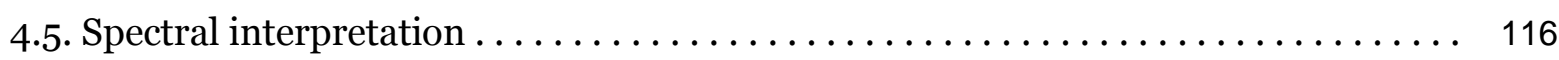

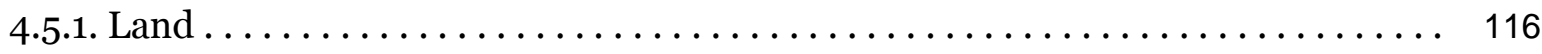

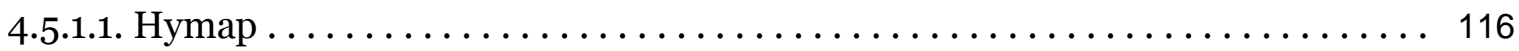

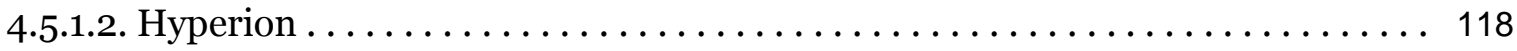

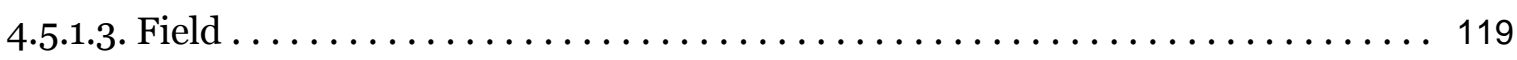

4.5.1.3.1. Flat surfaces . . . . . . . . . 121

4.5.1.3.2. Slopes ................................. 121

4.5.1.3.3. Dry mill tailing ponds $\ldots \ldots \ldots \ldots \ldots \ldots \ldots \ldots \ldots \ldots \ldots \ldots \ldots \ldots \ldots \ldots$

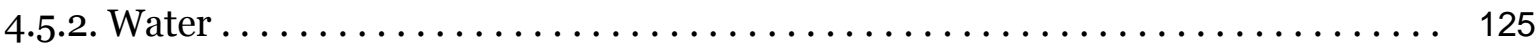

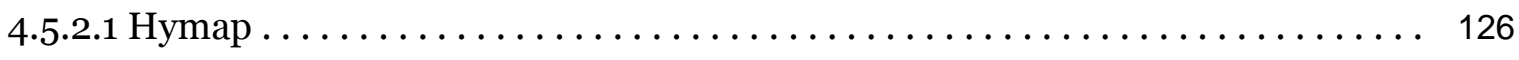




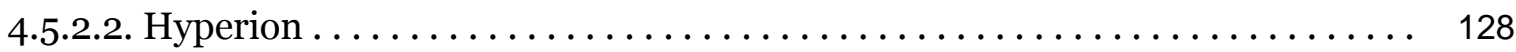

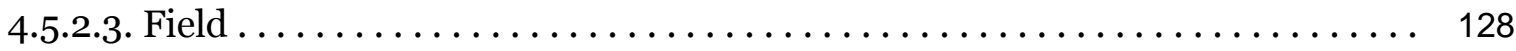

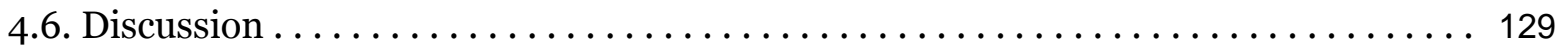

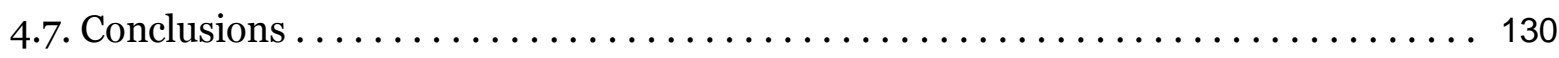

CHAPTER 5. MAPPING A CONTAMINATED RIVER COURSE WITH HYMAP DATA

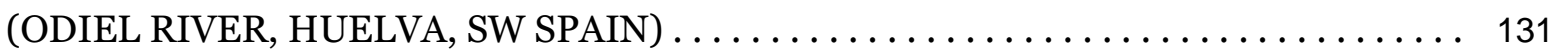

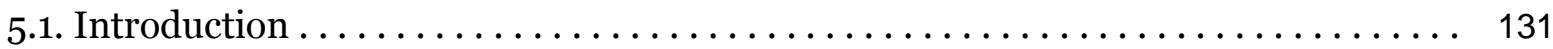

5.1.1. Geochemistry of the contamination $\ldots \ldots \ldots \ldots \ldots \ldots \ldots \ldots \ldots \ldots \ldots \ldots \ldots \ldots \ldots \ldots \ldots$

5.1.2. Acid mine drainage on the river Odiel . . . . . . . . . . . . . . . . 134

5.1.3. Geomorphological and hydrodynamical setting ................. 135

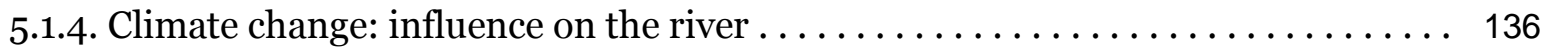

5.1.5. Imaging spectroscopy on the river $\ldots \ldots \ldots \ldots \ldots \ldots \ldots \ldots \ldots \ldots \ldots \ldots \ldots \ldots \ldots$

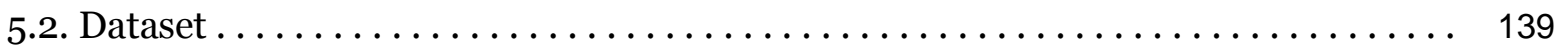

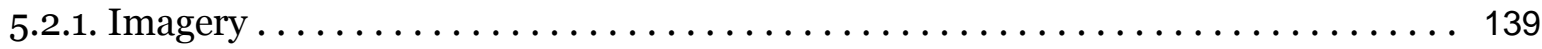

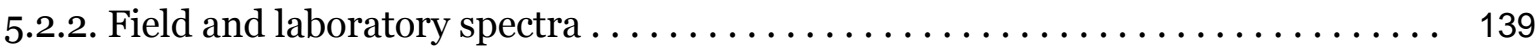

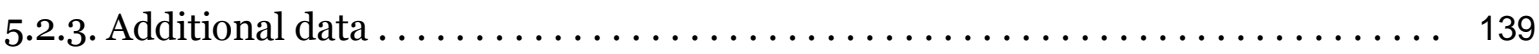

5.3. Spectral behaviour of mineral coatings over river sediments: main trends . . . . . 141

5.4. Change detection of mineral coatings over river sediments along the river Odiel

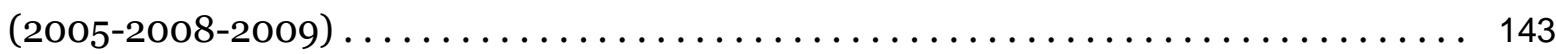

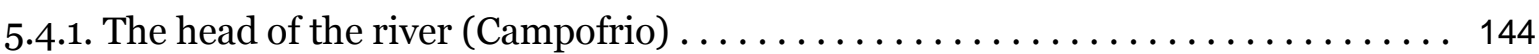

5.4.1.1. Geological and geomorphological setting .................. 144

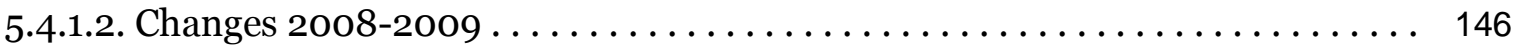

5.4.2. The first input of intense contamination (Puente de los Cinco Ojos) . . . . . . 146

5.4.2.1. Geological and geomorphological setting ................. 146

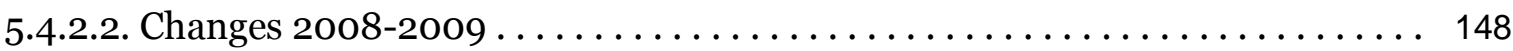

5.4.2.3. Mapping water $\mathrm{pH}$ with Hymap data ............................ 150

5.4.3. Bridge in the Calañas-Valverde del Camino road . . . . . . . . . . . . . . . 151

5.4.3.1. Geological and geomorphological setting $\ldots \ldots \ldots \ldots \ldots \ldots \ldots \ldots \ldots \ldots \ldots \ldots$ 


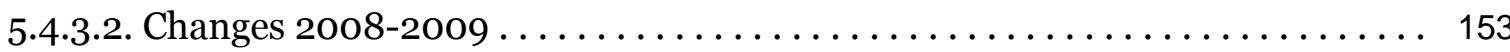

5.4.4. The mineworks along the river bank: Sotiel-Almagrera . . . . . . . . . . . 154

5.4.4.1. Geological and geomorphological setting .................. 154

5.4.4.2. Changes 2005-2008-2009 ....................... 154

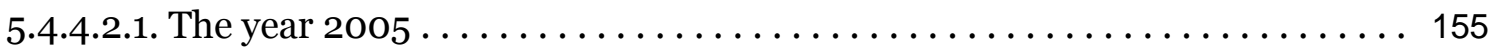

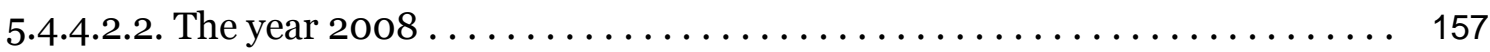

5.4.4.2.3. The year $2009 \ldots \ldots \ldots \ldots \ldots \ldots \ldots \ldots \ldots \ldots \ldots \ldots \ldots \ldots \ldots \ldots \ldots \ldots$

5.4.4.2.4. Summary of changes $2005-2008-2009 \ldots \ldots \ldots \ldots \ldots \ldots \ldots \ldots$

5.4.5. The typical knick-point pattern (wall south of the mine of Sotiel) . . . . . . . 159

5.4.5.1. Geological and geomorphological setting ................... 159

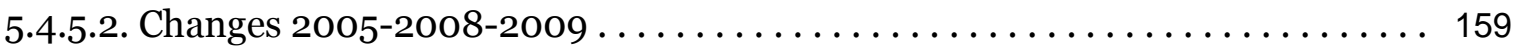

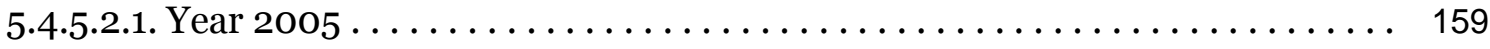

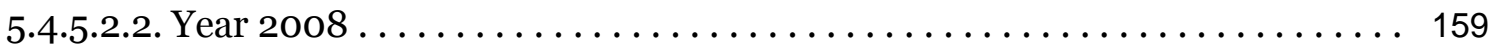

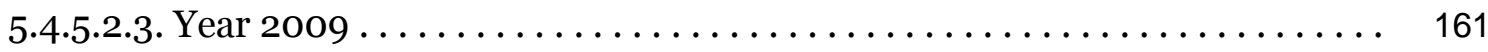

5.4.5.3. Summary of changes $2005-2008-2009 \ldots \ldots \ldots \ldots \ldots \ldots \ldots \ldots \ldots \ldots$

5.4.6. The linear encased river path (Fuente de la Corcha) $\ldots \ldots \ldots \ldots \ldots \ldots \ldots$

5.4.6.1. Geological and geomorphological setting . . . . . . . . . . . . . 162

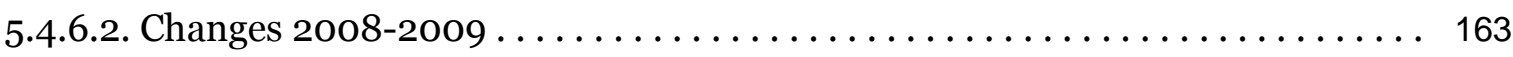

5.4 .7 . The entrance to the estuary (Gibraleón) $\ldots \ldots \ldots \ldots \ldots \ldots \ldots \ldots \ldots \ldots \ldots \ldots \ldots \ldots$

5.4.7.1. Geological and geomorphological setting $\ldots \ldots \ldots \ldots \ldots \ldots \ldots \ldots \ldots$

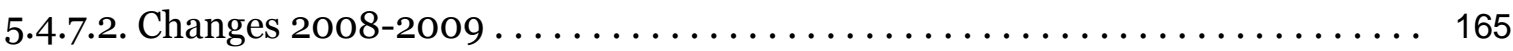

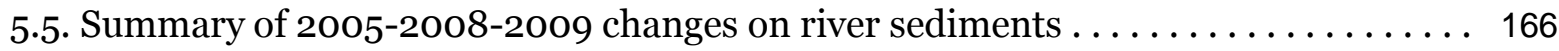

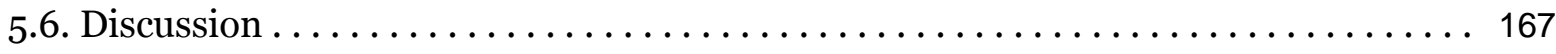

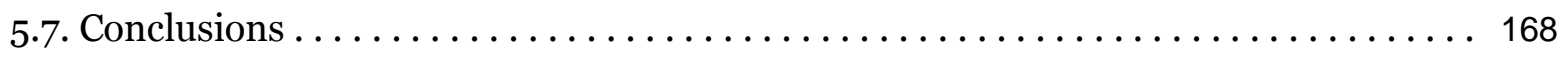

CHAPTER 6. GENERAL CONCLUSIONS $\ldots \ldots \ldots \ldots \ldots \ldots \ldots \ldots \ldots \ldots \ldots \ldots \ldots \ldots$

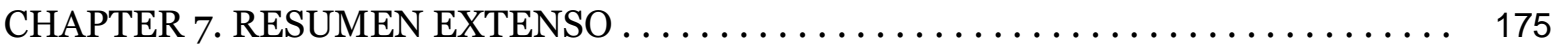

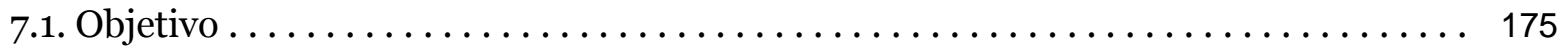

7.2. Resumen ....................................... 176 
7.4. Espectroscopía de imágenes aplicada al seguimiento de la contaminación

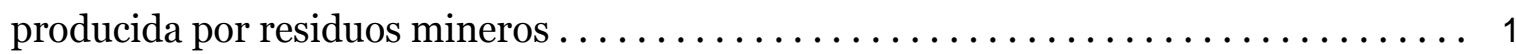

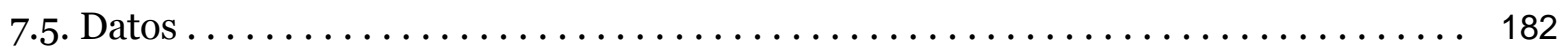

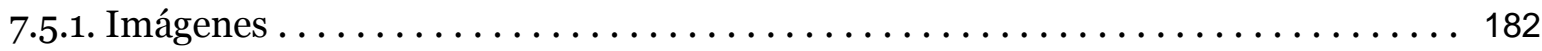

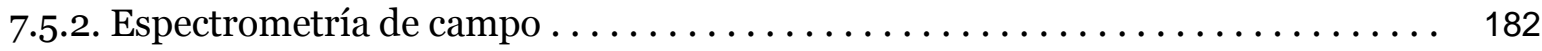

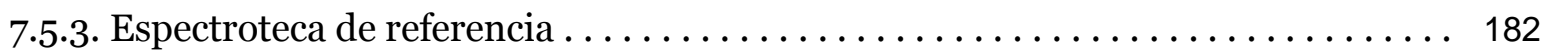

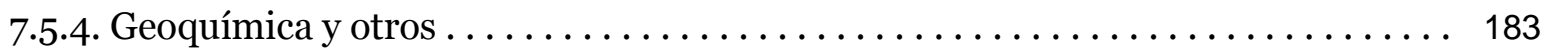

7.6. El tratamiento digital de imágenes como herramienta cartográfica $\ldots \ldots \ldots \ldots \ldots$

7.7. Cartografía de productos de oxidación de piritas en una mina en proceso de rehabilitación (Sotiel, Huelva) con imágenes hiperespectrales aeroportadas Hymap . . .

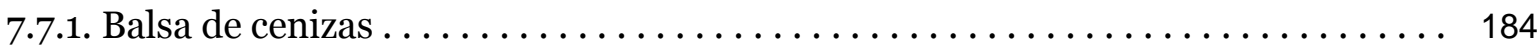

7.7.2. Escombreras . . . . . . . . . . 185

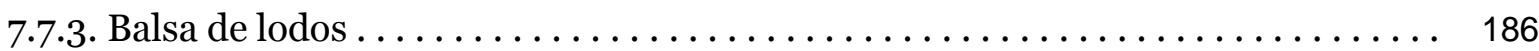

7.7.4. Planta de tratamiento de menas . . . . . . . . . . . . . . . . . . . 186

7.8. Cartografía de residuos mineros y cuerpos de agua en una mina de sulfuros de hierro con imágenes aeroportadas Hymap y imágenes Hyperion de satélite (mina de Las Herrerías, Huelva) . . . . . . . . . . . . . . . . . . . . . . .

7.9. Cartografía de un río contaminado con datos aeroportados Hymap (Río Odiel,

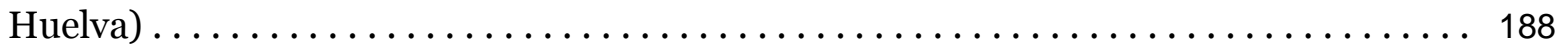

7.9.1. La cabecera del río (Campofrío) $\ldots \ldots \ldots \ldots \ldots \ldots \ldots \ldots \ldots \ldots \ldots \ldots \ldots \ldots \ldots \ldots \ldots \ldots \ldots$

7.9.2. El primer aporte de contaminación intensa (Puente de los Cinco Ojos) . . . . . 190

7.9.2.1. Cartografía de sedimentos y costras . . . . . . . . . . . . . . . 190

7.9.2.2. Cartografía del agua del río en relación con la acidez $(\mathrm{pH}) \ldots \ldots \ldots \ldots \ldots . \quad 191$

7.9.3. El curso medio superior (Puente en la carretera de Calañas-Valverde del

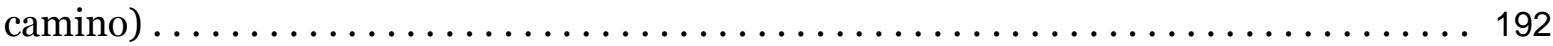

7.9.4. Las minas en la orilla del río (Sotiel) $\ldots \ldots \ldots \ldots \ldots \ldots \ldots \ldots \ldots \ldots \ldots \ldots$

7.9.5. El ejemplo de la típica ruptura de pendiente (Presa al sur de Sotiel) . . . . . . 192

7.9.6. El curso medio encajado con trayectoria lineal (Fuente de la Corcha) . . . . . . 193

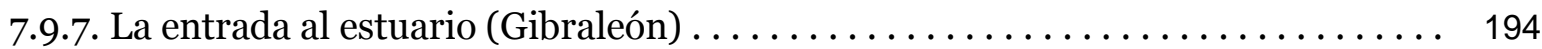




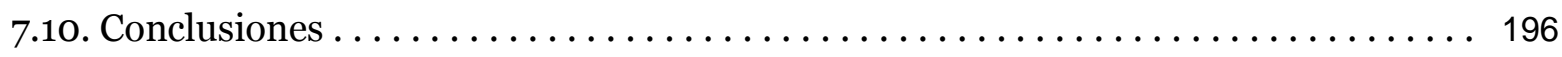

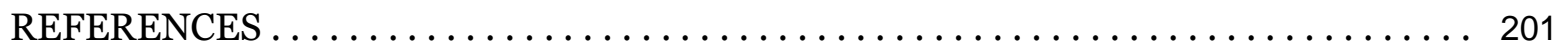




\section{ÍNDICE}

\section{ESPECTROSCOPÍA DE IMÁGENES PARA EL SEGUIMIENTO DE LA CONTAMINACIÓN RELACIONADA CON MINAS DE SULFUROS EN LA FAJA PIRÍTICA IBÉRICA MEDIANTE SENSORES HIPERESPECTRALES (PROVINCIA DE HUELVA)}

Jorge Buzzi Marcos

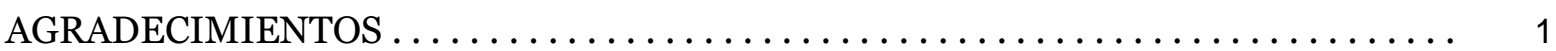

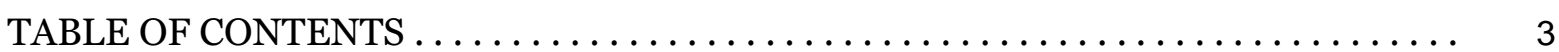

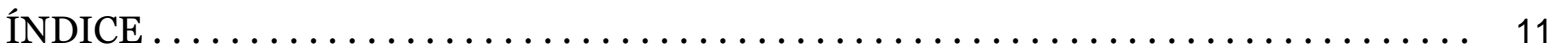

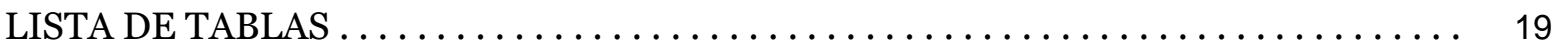

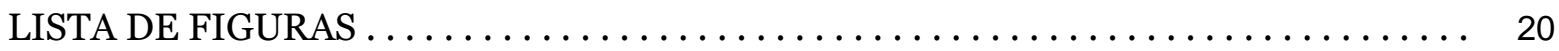

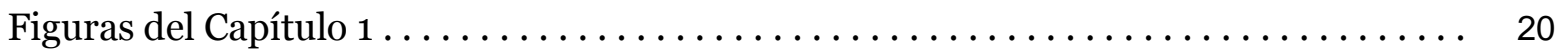

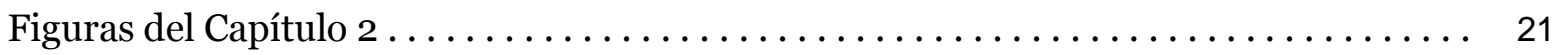

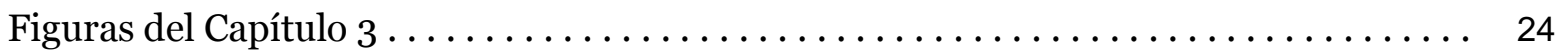

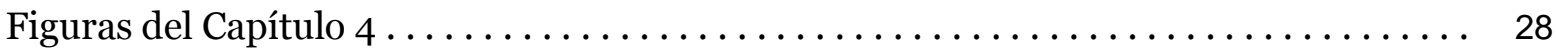

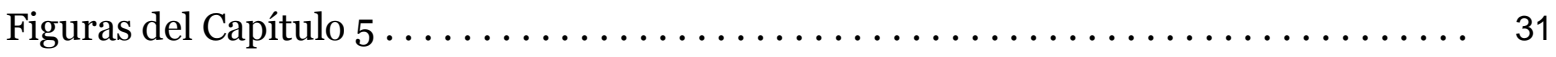

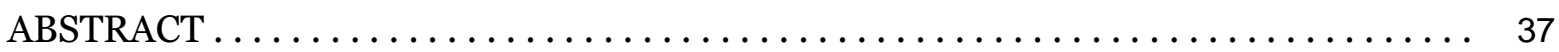

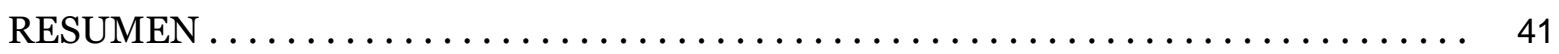

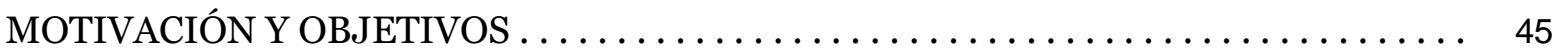

CAPÍTULO 1. RESIDUOS MINEROS Y DRENAJE ÁCIDO DE MINA BAJO EL PUNTO DE VISTA DE LA ESPECTROSCOPÍA DE IMÁGENES: ESTADO DEL CONOCIMIENTO ...................................... 47

1.1. Introducción ........................................ 47

1.2. Herramientas de seguimiento hiperespectral $\ldots \ldots \ldots \ldots \ldots \ldots \ldots \ldots \ldots .48$

1.3. Meteorización de residuos mineros ricos en pirita .................. 49 


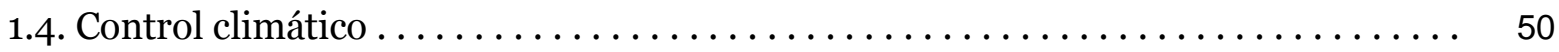

1.5. Geología regional y clima $\ldots \ldots \ldots \ldots \ldots \ldots \ldots \ldots \ldots \ldots \ldots \ldots \ldots \ldots \ldots \ldots \ldots \ldots \ldots \ldots \ldots$

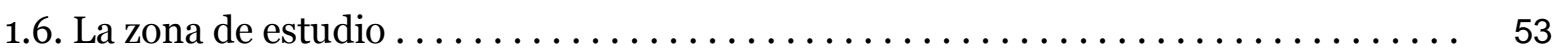

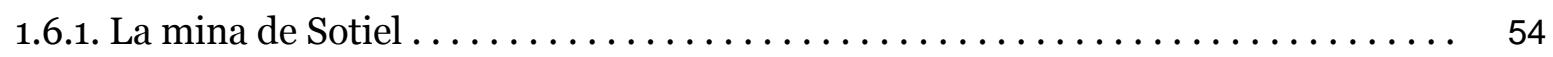

1.6.2. La mina de Las Herrerías $\ldots \ldots \ldots \ldots \ldots \ldots \ldots \ldots \ldots \ldots \ldots \ldots \ldots \ldots \ldots \ldots \ldots \ldots \ldots$

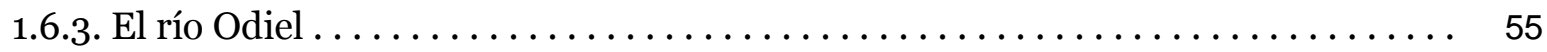

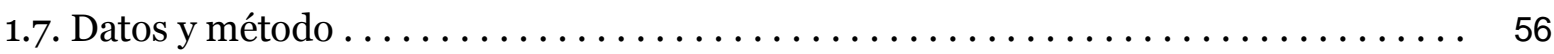

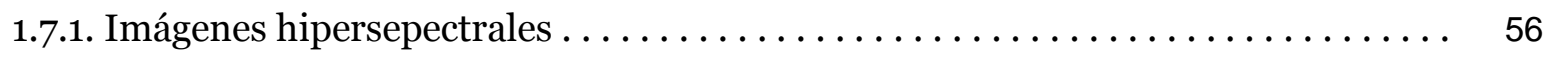

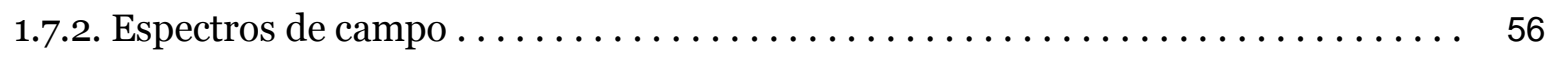

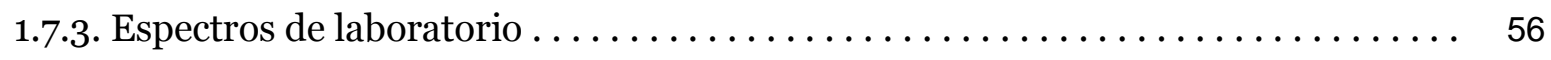

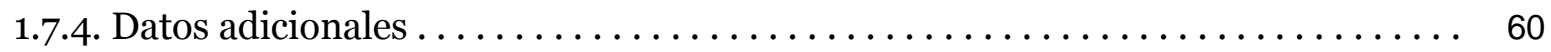

1.7.4.1. Cuerpos de agua permanentes de las minas $\ldots \ldots \ldots \ldots \ldots \ldots \ldots \ldots .60$

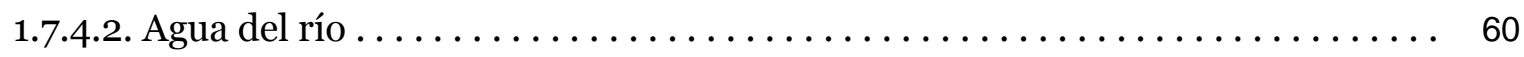

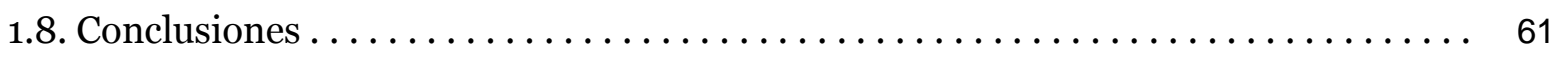

CAPÍTULO 2. CARTOGRAFÍA MEDIANTE PROCESADO DE IMÁGENES

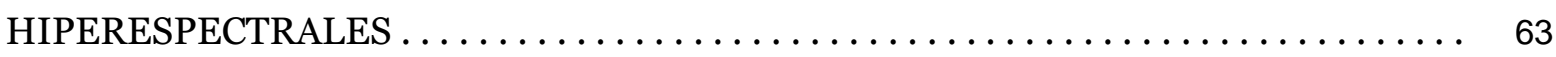

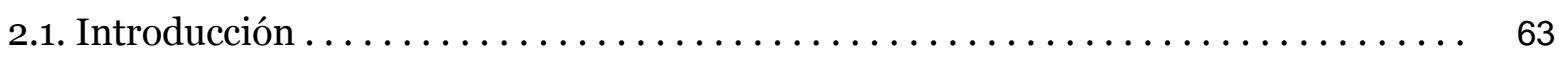

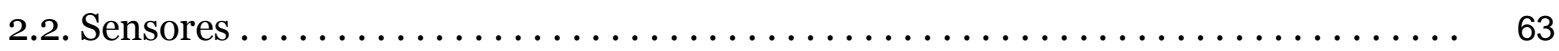

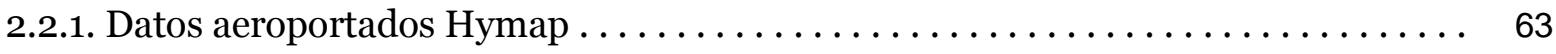

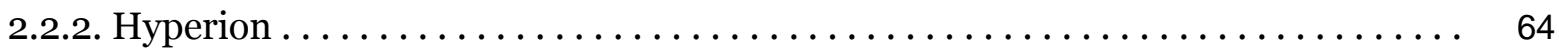

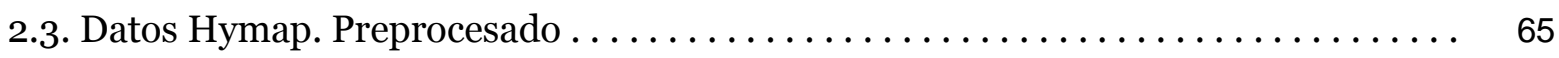

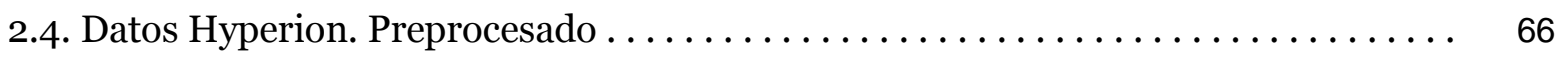

2.5. Secuencia de procesado de imágenes hiperespectrales $\ldots \ldots \ldots \ldots \ldots \ldots \ldots \ldots \quad 67$

2.6. Uso de espectrotecas de referencia $\ldots \ldots \ldots \ldots \ldots \ldots \ldots \ldots \ldots \ldots \ldots \ldots \ldots$

2.7. Procesado de imágenes para cartografiar la contaminación en los residuos mineros 71

2.8. Procesado de imágenes para cartografiar la contaminación en el río . . . . . . . . 74

2.9. El Modelo Automático Gaussiano Modificado. Un nuevo método de exploración. . . 76

2.9.1. Evaluación de parámetros a partir del análisis derivativo de espectros de datos 
2.10. Conclusiones .

CAPÍTULO 3. CARTOGRAFÍA DE PRODUCTOS DE LA METEORIZACIÓN DE LA PIRITA EN UNA MINA EN REHABILITACIÓN MEDIANTE DATOS HIPERESPECTRALES AEROPORTADOS HYMAP (SOTIEL, HUELVA, SW ESPAÑA) • 83

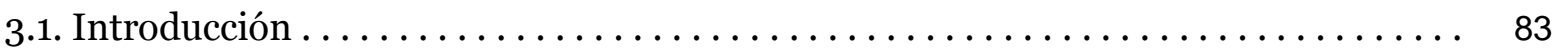

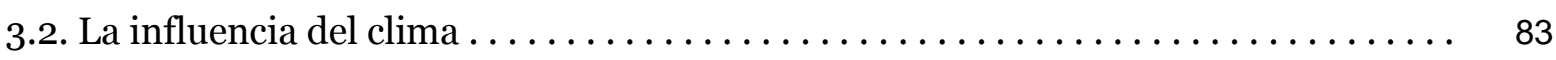

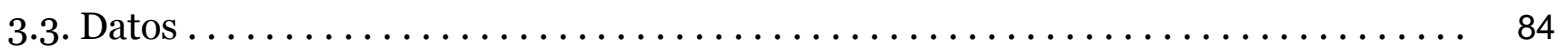

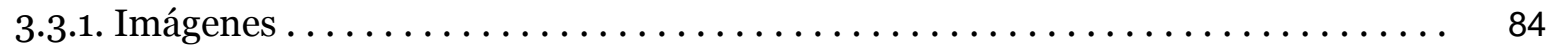

3.3.2. Espectros de campo y laboratorio. $\ldots \ldots \ldots \ldots \ldots \ldots \ldots \ldots \ldots \ldots \ldots \ldots \ldots$

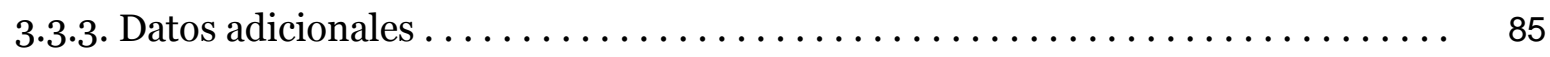

3.4. Las instalaciones mineras de Sotiel $\ldots \ldots \ldots \ldots \ldots \ldots \ldots \ldots \ldots \ldots \ldots \ldots \ldots \ldots \ldots \ldots \ldots$

3.5. Detección de cambios en 2005-2008-2009 en la mina de Sotiel . . . . . . . . 87

3.5.1. La balsa de cenizas $\ldots \ldots \ldots \ldots \ldots \ldots \ldots \ldots \ldots \ldots \ldots \ldots \ldots \ldots \ldots \ldots \ldots$

3.5.2. Las escombreras junto al río $\ldots \ldots \ldots \ldots \ldots \ldots \ldots \ldots \ldots \ldots \ldots \ldots \ldots \ldots \ldots \ldots \ldots \ldots \ldots \ldots$

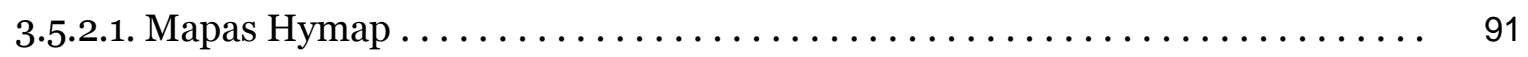

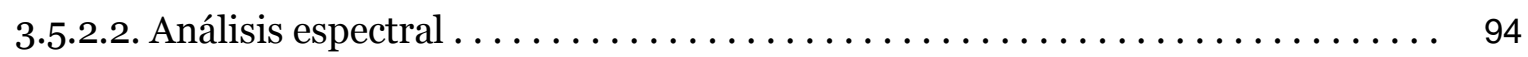

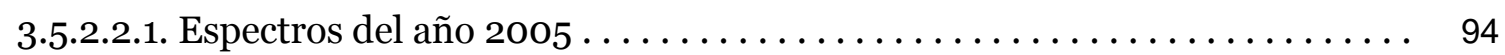

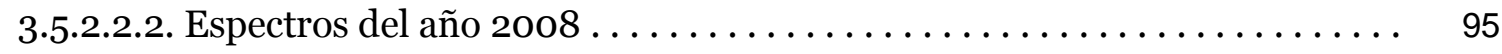

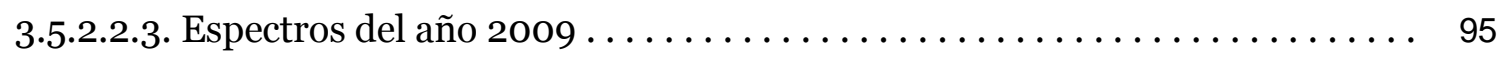

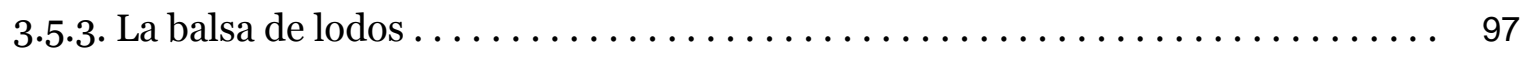

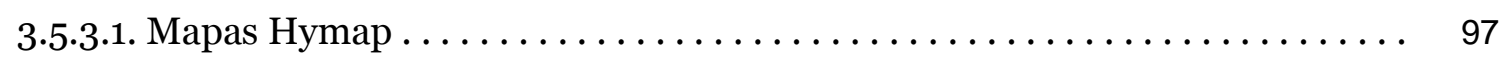

3.5.3.1.1. Mapas Hymap en $2005 \ldots \ldots \ldots \ldots \ldots \ldots \ldots \ldots \ldots \ldots \ldots \ldots \ldots \ldots \ldots \ldots$

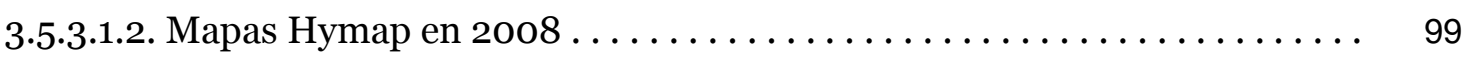

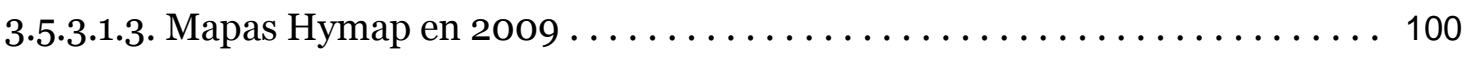

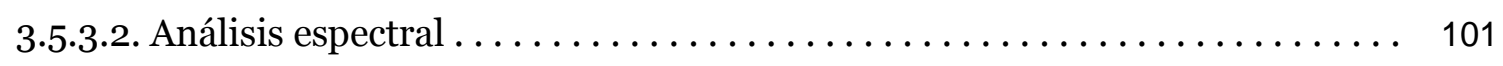

3.5.3.2.1. Espectros del año $2005 \ldots \ldots \ldots \ldots \ldots \ldots \ldots \ldots \ldots \ldots \ldots \ldots \ldots \ldots \ldots \ldots \ldots \ldots \ldots$

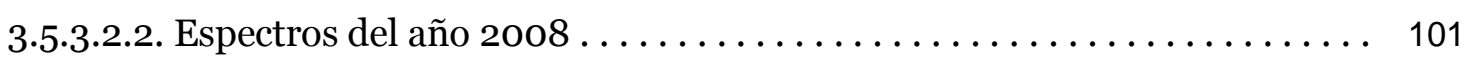




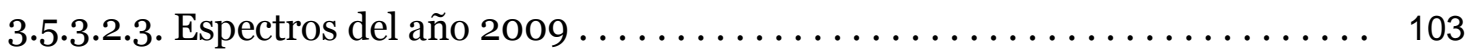

3.5.4. La planta de tratamiento y los alrededores $\ldots \ldots \ldots \ldots \ldots \ldots \ldots \ldots \ldots \ldots$

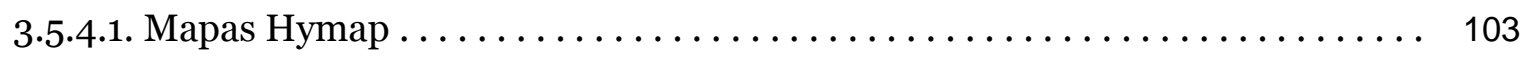

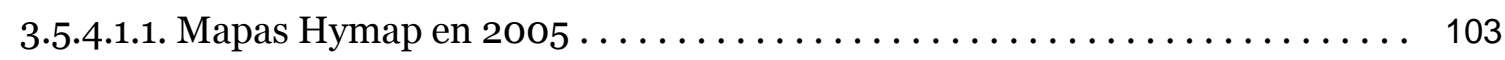

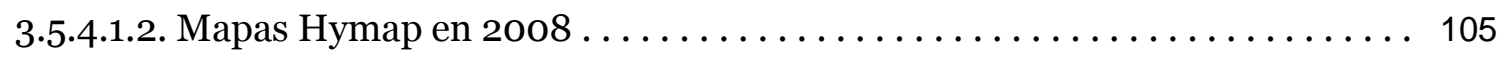

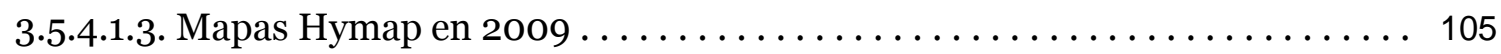

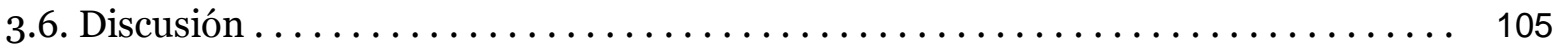

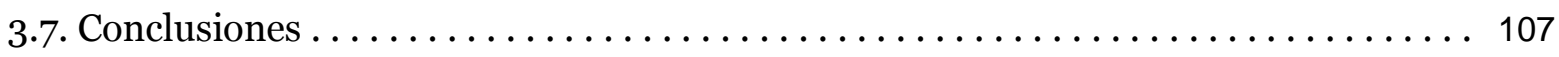

CAPÍTULO 4. CARTOGRAFÍA DE RESIDUOS Y DE AGUA EN UNA MINA DE SULFUROS DE HIERRO MEDIANTE DATOS HYPERESPECTRALES AEROPORTADOS HYMAP Y DATOS HIPERESPECTRALES ESPACIALES

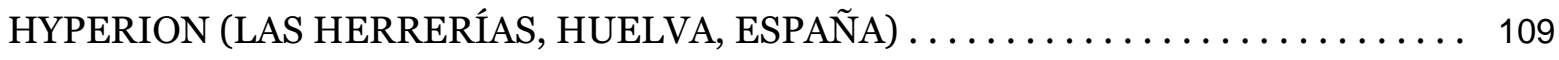

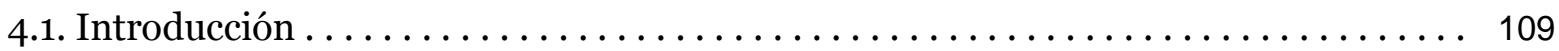

4.2. Rasgos espectrales de los residuos de la pirita, drenaje ácido de mina y balsas

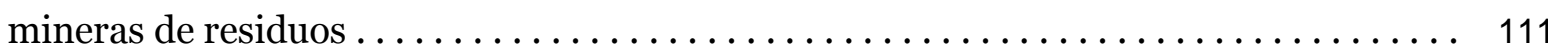

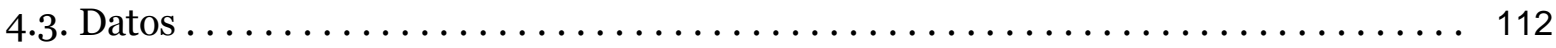

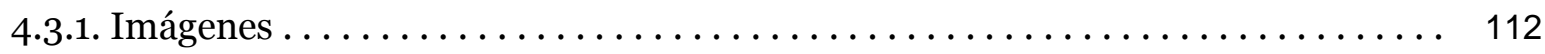

4.3.2. Geología y estudio de laboratorio $\ldots \ldots \ldots \ldots \ldots \ldots \ldots \ldots \ldots \ldots \ldots \ldots \ldots \ldots \ldots$

4. 4. Cartografía mediante procesado de imágenes. ................ 114

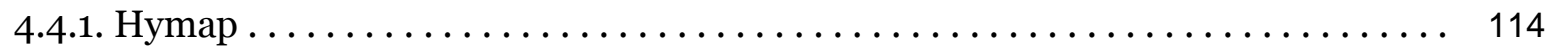

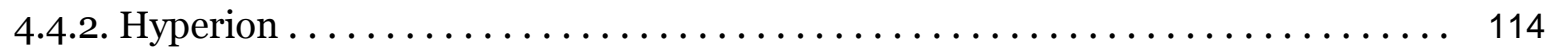

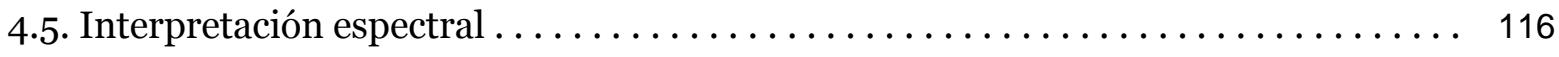

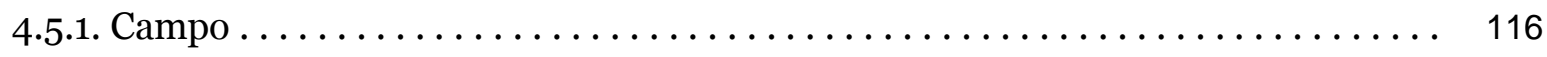

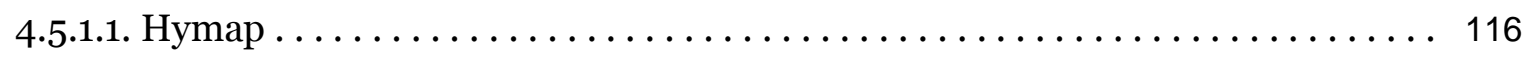

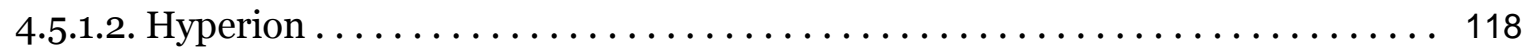

4.5.1.3. Campo ..................................... 119

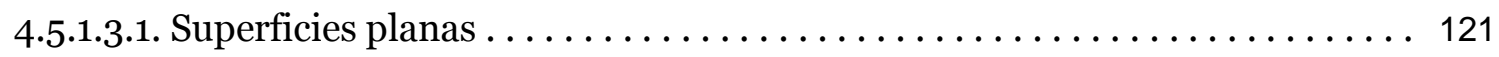

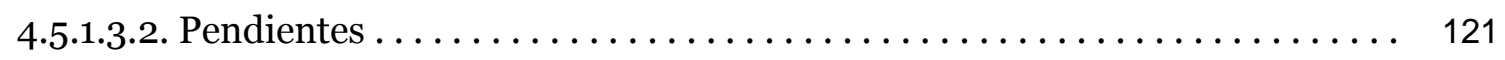

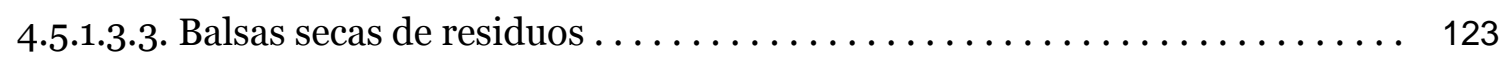


$4 \cdot 5.2 .1$ Hymap . . . . . . . . . . . . . . . . . . . . . . . . . . . 126

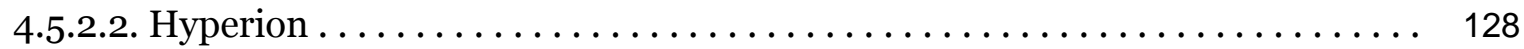

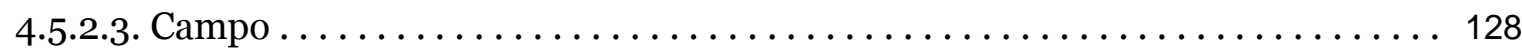

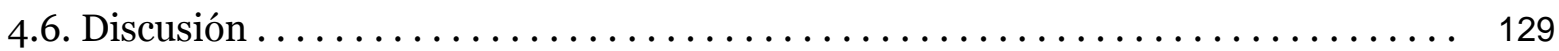

4.7. Conclusiones ....................................... 130

CAPÍTULO 5. CARTOGRAFÍA DEL CURSO CONTAMINADO DE UN RÍO CON

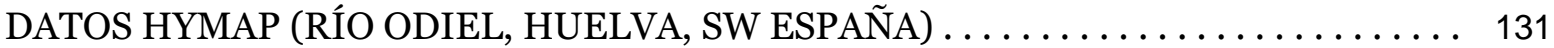

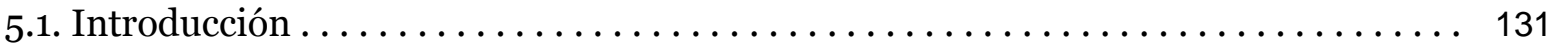

5.1.1. Geoquímica de la contaminación $\ldots \ldots \ldots \ldots \ldots \ldots \ldots \ldots \ldots \ldots \ldots \ldots \ldots \ldots \ldots \ldots \ldots$

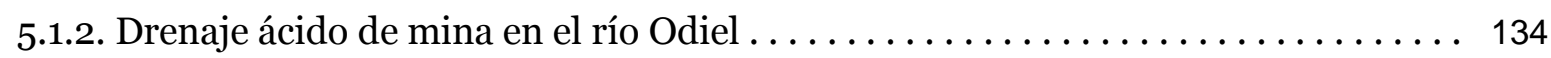

5.1.3. Geomorfología e hidrodinámica ........................ 135

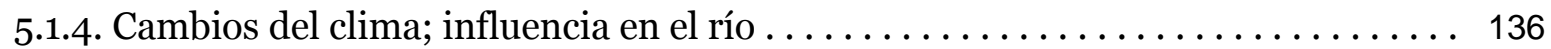

5.1.5. Espectroscopía de imágenes en el río $\ldots \ldots \ldots \ldots \ldots \ldots \ldots \ldots \ldots \ldots \ldots \ldots \ldots$

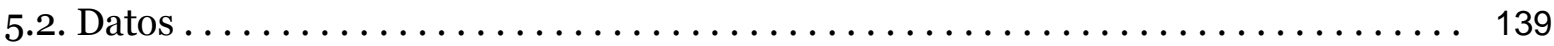

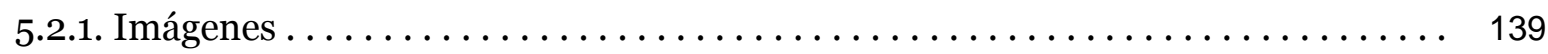

5.2.2. Espectros de campo y de laboratorio. ...................... 141

5.2.3. Datos adicionales. . . . . . . . . . . . . . . . . . . . . . . 139

5.3. Comportamiento espectral de costras minerales sobre los sedimentos del río: principales tendencias . . . . . . . . . . . . . . . . . . . . . . . . . 141

5.4. Detección de cambios en las costras minerales sobre los sedimentos del río Odiel

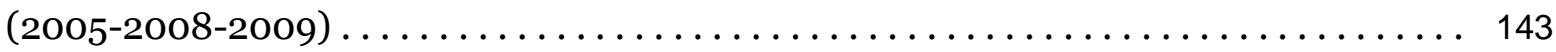

5.4.1. La cabecera del río (Campofrio) $\ldots \ldots \ldots \ldots \ldots \ldots \ldots \ldots \ldots \ldots \ldots \ldots \ldots \ldots \ldots \ldots \ldots \ldots \ldots$

5.4.1.1. Geología y geomorfología . . . . . . . . . . . . . . . . . . . . 144

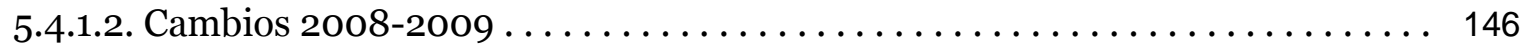

5.4.2. El primer aporte intenso de contaminación (Puente de los Cinco Ojos) . . . . . 146

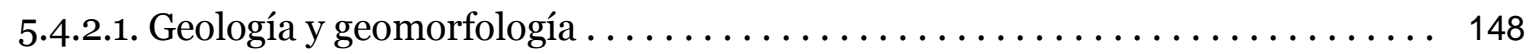

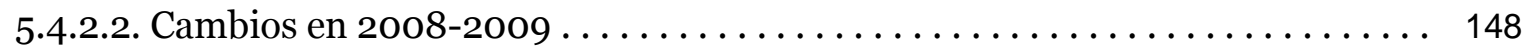

5.4.2.3. Cartografía del $\mathrm{pH}$ del agua mediante datos Hymap . . . . . . . . . . . . . 150 
5.4.3. El puente de la carretera Calañas-Valverde del Camino. . . . . . . . . . . 151

5.4.3.1. Geología y geomorfología . . . . . . . . . . . . . . . . . . . 151

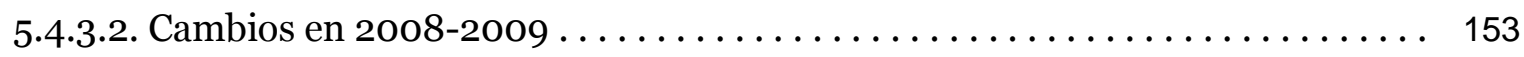

5.4.4. Las minas junto a la orilla del río: Sotiel-Almagrera . . . . . . . . . . . . 154

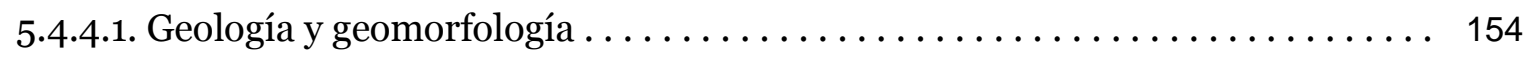

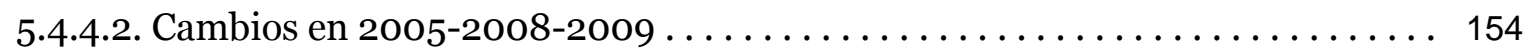

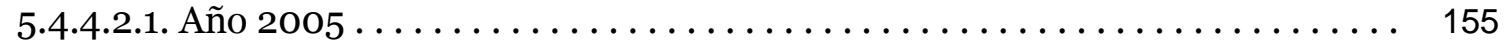

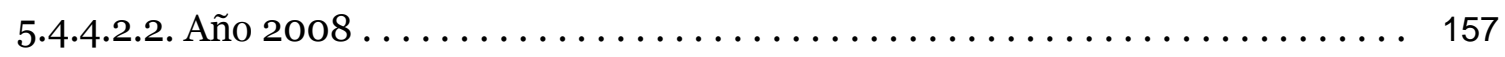

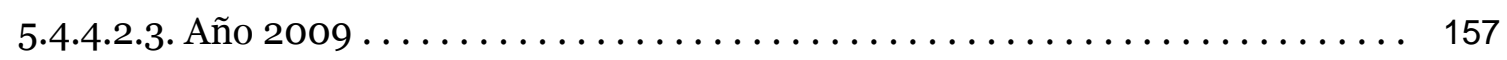

5.4.4.2.4. Resumen de los cambios en 2005-2008-2009 ............ 158

5.4.5. El patron típico de un punto de ruptura de la pendiente (presa sur de la mina de

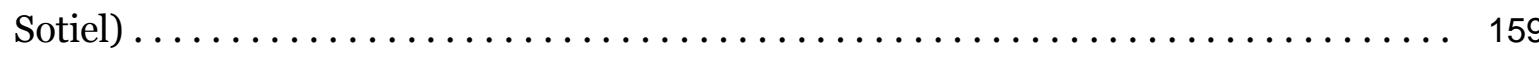

5.4.5.1. Geología y geomorfología . . . . . . . . . . . . . . . . . . 159

5.4.5.2. Cambios 2005-2008-2009 ......................... 159

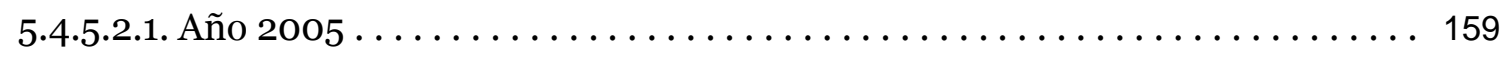

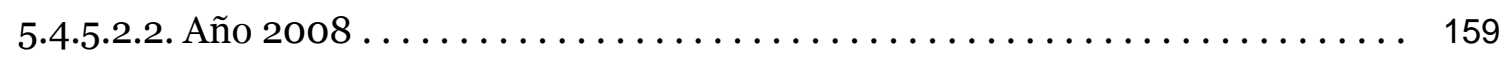

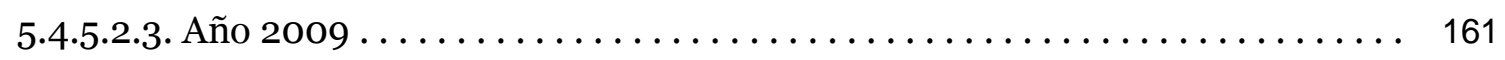

5.4.5.3. Resumen de los cambios en 2005-2008-2009 ............... 161

5.4.6. El tramo linear encajado del cauce (Fuente de la Corcha) . . . . . . . . . 162

5.4.6.1. Geología y geomorfología . . . . . . . . . . . . . . . . . . 162

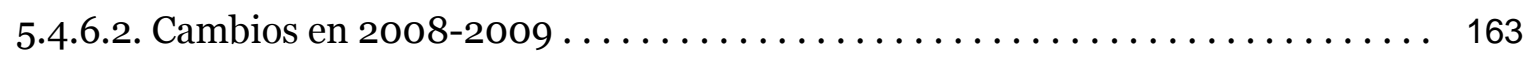

5.4.7. La entrada en el estuario (Gibraleón) $\ldots \ldots \ldots \ldots \ldots \ldots \ldots \ldots \ldots \ldots \ldots \ldots \ldots \ldots \ldots \ldots$

5.4.7.1. Geología y geomorfología $\ldots \ldots \ldots \ldots \ldots \ldots \ldots \ldots \ldots \ldots \ldots \ldots \ldots \ldots \ldots \ldots \ldots \ldots \ldots \ldots$

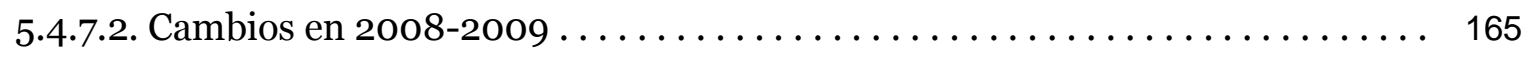

5.5. Resumen de los cambios en los sedimentos del río en 2005-2008-2009 . . . . . 166

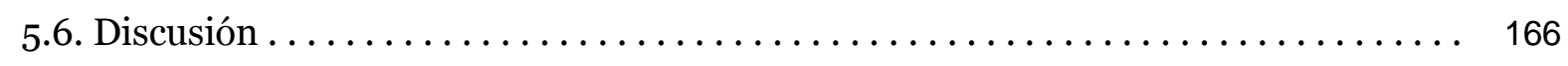

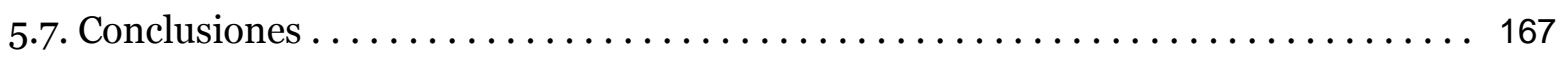

CAPÍTULO 6. CONCLUSIONES GENERALES $\ldots \ldots \ldots \ldots \ldots \ldots \ldots \ldots \ldots \ldots \ldots$ 


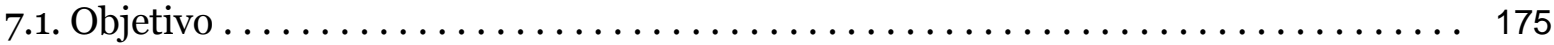

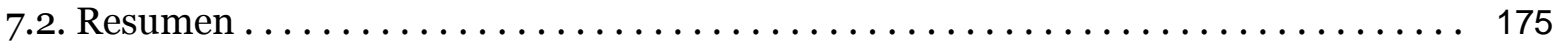

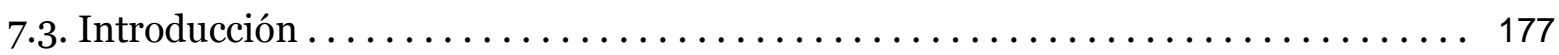

7.4. Espectroscopía de imágenes aplicada al seguimiento de la contaminación

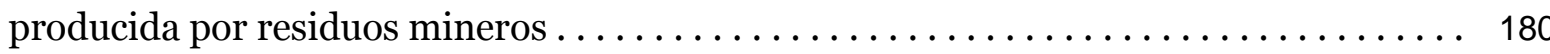

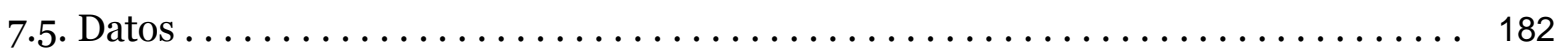

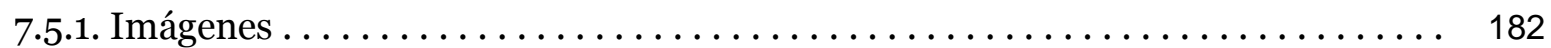

7.5.2. Espectrometría de campo ........................... 182

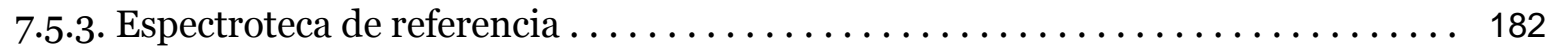

7.5.4. Geoquímica y otros . . . . . . . . . . . 183

7.6. El tratamiento digital de imágenes como herramienta cartográfica . . . . . . . 183

7.7. Cartografía de productos de oxidación de piritas en una mina en proceso de rehabilitación (Sotiel, Huelva) con imágenes hiperespectrales aeroportadas Hymap . . .

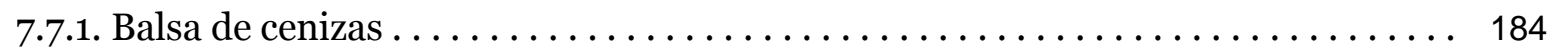

7.7.2. Escombreras . . . . . . . . . . . 185

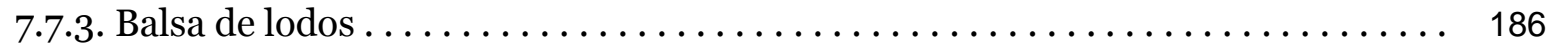

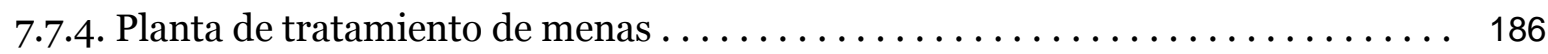

7.8. Cartografía de residuos mineros y cuerpos de agua en una mina de sulfuros de hierro con imágenes aeroportadas Hymap y imágenes Hyperion de satélite (mina de

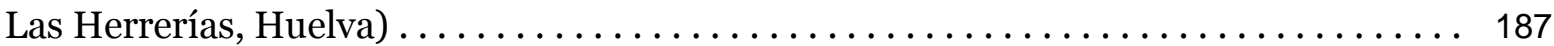

7.9. Cartografía de un río contaminado con datos aeroportados Hymap (Río Odiel,

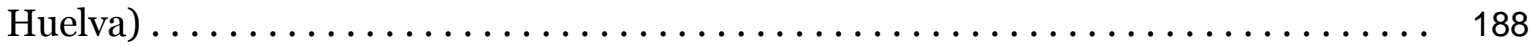

7.9.1. La cabecera del río (Campofrío) $\ldots \ldots \ldots \ldots \ldots \ldots \ldots \ldots \ldots \ldots \ldots \ldots \ldots \ldots$

7.9.2. El primer aporte de contaminación intensa (Puente de los Cinco Ojos) . . . . . 189

7.9.2.1. Cartografía de sedimentos y costras . . . . . . . . . . . . . . . . 190

7.9.2.2. Cartografía del agua del río en relación con la acidez $(\mathrm{pH}) \ldots \ldots \ldots \ldots \ldots . \quad 190$

7.9.3. El curso medio superior (Puente en la carretera de Calañas-Valverde del

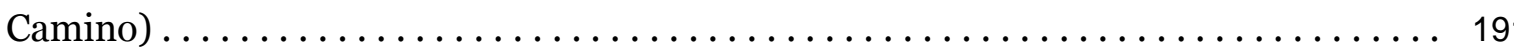

7.9.4. Las minas de la orilla del río (Sotiel) $\ldots \ldots \ldots \ldots \ldots \ldots \ldots \ldots \ldots \ldots \ldots \ldots \ldots \ldots \ldots$ 
7.9.5. El ejemplo de la típica ruptura de pendiente (Presa al sur de Sotiel) . . . . . . 192

7.9.6. El curso medio encajado con trayectoria lineal (Fuente de La Corcha) . . . . . . 192

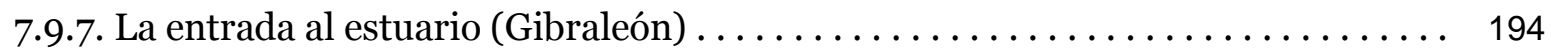

7.10. Conclusiones . . . . . . . . . . 196

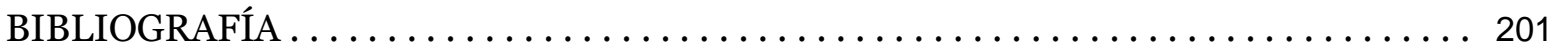




\section{LIST OF TABLES}

\section{CHAPTER 2}

Table 2.1. HyMAP technical specifications (Cocks et al., 1998).

Tabla 2.1. Características técnicas del sensor Hymap (Cocks et al., 1998).

Table 2.2. Hyperion technical specifications (USGS, 2004).

Tabla 2.2. Características técnicas del sensor Hyperion (USGS, 2004).

Table 2.3. Configuration of the ASD FieldSpec 3 Spectrometer (ASD, 2006).

Tabla 2.3. Configuración del espectrómetro ASD FieldSpec 3 (ASD, 2006). 


\section{LIST OF FIGURES}

\section{CHAPTER 1}

Figure 1.1. Location of the study area in the Iberian Hesperian Massif (Spain and Portugal) (blue circle). In: Vera et al., 2004. Blue dots are the locations of the mine sites and the Odiel River.

Figura 1.1. Situación del área de estudio en el Macizo Hespérico Ibérico (España y Portugal) (círculo azul). En: Vera et al., 2004. Los puntos azules son localidades de las minas estudiadas, y el río Odiel.

Figure 1.2. River basin of the Odiel River, with enhanced contaminated parts (in Sarmiento et al., 2009).

Figura 1.2. Cuenca de drenaje del río Odiel, con zonas contaminadas en trazo grueso (Sarmiento et al., 2009).

Figure 1.3. The test sites. A: Mine site of Sotiel. B: Dumps at the mine site of Las Herrerías. C: Braided riverbars in the Odiel River.

Figura 1.3. Las zonas de estudio. A: Mina de Sotiel. B: Escombreras en la mina de Las Herrerías. C: Barras fluviales trenzadas en el río Odiel.

Figure 1.4. Calibration targets. A, B and C: Large spectrally homogeneous urban sites used as calibration targets. D and E: Location of the calibration targets in the towns of Calañas and Gibraleón.

Figura 1.4. Blancos de calibrado. A, B y C: superficies urbanas espectralmente homogéneas suficientemente grandes como para servir de blancos de calibrado de líneas de vuelo. D y E: Situación de los blancos de calibrado en los pueblos de Calañas y Gibraleón.

Figure 1.5. Mosaic with the six Hymap flight lines covering the flow path of the Odiel River in 2008, with test sites and locations and dates of field spectra.

Figura 1.5. Mosaico con las seis líneas de vuelo que recorren el curso del río Odiel en 2008, con las zonas de estudio y la situación y fechas en las que se tomaron espectros de campo. 


\section{CHAPTER 2}

Figure 2.1. Road map showing subsequent image processing steps on Hymap imagery leading to a map of pyrite weathering products on abandoned mine sites.

Figura 2.1. Esquema que resume las etapas de tratamiento de imágenes Hymap hasta el mapa final de productos de meteorización de piritas en minas abandonadas.

Figure 2.2. Sequential subscenes produced by image processing (from left to right). A: False colour composite with Hymap channels 9 (o.5568 $\mu \mathrm{m}), 28(0,8460 \mu \mathrm{m})$ and 109 $(2,2074 \mu \mathrm{m})$. B: Land use map estimating vegetation cover and open soil. C: Mask for vegetation. D: Mask for mine waste. E: Mask for the river flow path. F: mask for hydrated tailings. G: Mask for oxidised dumps. H: Mask for hydrated ponds around the ore processing plant. I: Mask for the hydrated mill tailings dam. J: Mask for the oxidised pond of ashes. K. Mask for the main oxidised dump by the river. L: Spectral reference library on pyrite weathering products (Crowley et al., 2003; Clark et al., 2007). Spectra are displaced vertically for clarity. M: Final map of coatings of pyrite weathering products over mine waste and river sediments following the reference spectral library (Crowley et al., 2003).

Figura 2.2. Secuencia de subescenas producidas durante el tratamiento de imágenes (de izquierda a derecha). A: composición en falso color con los canales Hymap 9 $(0.5568 \mu \mathrm{m}), 28(0,8460 \mu \mathrm{m})$ y $109(2,2074 \mu \mathrm{m})$. B: Mapa de uso de suelo que indica la superficie cubierta por vegetación y suelo descubierto. C: Máscara para la vegetación. D: Máscara para los residuos mineros. E: Máscara para el cauce del río. F: Máscara para las balsas con barros cubiertos por sulfatos hidratados. G: Máscara para las escombreras de fragmentos de roca con pátinas oxidadas. H: Máscara para las balsas de barros con sulfatos hidratados alrededor de la planta de tratamiento de menas. I: Máscara para la balsa de lodos. J: Máscara para la balsa de cenizas oxidadas. K: Máscara para la escombrera oxidada mayor a orillas del río. L: Espectroteca de referencia de productos de meteorización de piritas (Crowley et al., 2003; Clark et al., 2007). M: Mapa final de costras de productos de meteorización de piritas sobre residuos mineros y sedimentos fluviales diagnosticados con la espectroteca de referencia de productos de meteorización de piritas.

Figure 2.3. A, B, C and D: Maps compiled from Hymap data on the minerals product of oxidation and dehydration of sulphide sludge, on the four available flights. Colour 
coding for minerals mapped with the corresponding chemical formula, arranged on a precipitation and oxidation sequence. Increasing reddish colours suggest intense oxidation. Bluish and greenish colours concentrate on hydrated areas. E: Location of domains within the mine site extracted on open land after excluding bare open land and cultivated land. Colours are displayed for clarity, and have no relationship with the legend of minerals on the left.

Figura 2.3. A, B, C y D: Mapas elaborados con datos Hymap de productos de oxidación de deshidratación de lodos de sulfuros, en los cuatro vuelos disponibles. Leyenda de minerales correspondientes con su fórmula química, siguiendo la secuencia de precipitación y oxidación progresiva en el proceso de meteorización. Los colores rojizos indican oxidación predominante. Los colores azulados y verdosos indican predominio de sulfatos hidratados. E: Situación de los entornos cartografiados en el área de la mina, extraído digitalmente a partir de una máscara para el suelo descubierto y zonas cultivadas. Los colores no tienen relación con la leyenda de los mapas anteriores.

Figure 2.4. Sequence of hyperspectral image processing to produce a map of the river flow path.

Figura 2.4. Secuencia de algoritmos de tratamiento digital de imágenes utilizados para la elaboración del mapa del cauce del río.

Figure 2.5. A: False colour composite image with Hymap channels 16 (0.6755 $\mu \mathrm{m}), 26$ $(0.8188 \mu \mathrm{m})$ and $108(2.1917 \mu \mathrm{m})$. B: Mask for the flow path. C: Mask for water. D: Map of fluvial sediments. E: Map of coatings of precipitates from acid water with dissolved iron sulphide over river sediments. Legend as map on Figure 2.2L.

Figura 2.5. A: Composición en falso color con los canales Hymap 16 (o.6755 $\mu \mathrm{m}), 26$

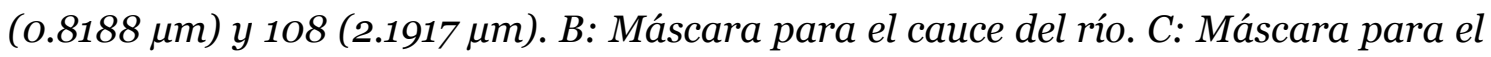
agua. D: Mapa de sedimentos fluviales. E: Mapa de costras en sedimentos, con minerales que precipitan a partir de aguas ácidas con productos disueltos procedentes de la meteorización de sulfuros de hierro. Misma leyenda que el mapa de la Figura 2.2L.

Figure 2.6. Spectra of soil (below). Derivative of the spectra of soil (above). The derivative extracts minimum, maximums and inflexion points from the shape of the spectra. On a single deep absorption position of electromagnetic energy on a spectra: 
expressions of Spectral Contrast, and Full Width at Half Maximum (FWHM). (in Verpoorter et al., 2009).

Figura 2.6. Espectro de suelo (abajo). Derivada del espectro de suelo (arriba). La derivada extrae puntos máximos, mínimos y de inflexión en la forma del espectro. En una banda de absorción de energía electromagnética en un espectro: posición de la longitud de onda, expresión del Contraste Espectral, y de la Anchura Maxima a Mitad del Máximo (FWHM). (in Verpoorter et al., 20o9).

Figure 2.7. Geological units mapped from Hymap data. A: Hymap spectra of the selected geological units. B: Spectra of minerals diagnosed for the Hymap geological units included in the reference mineral spectral library (Crowley et al., 2003) for pyrite weathering products. C: Continuum removed spectra for the Hymap spectra of the mapped geological units.

Figura 2.7. Unidades geológicas cartografiadas con datos Hymap. Espectros extraídos de las imágenes Hymap correspondientes a las unidades geológicas cartografiadas incluidos en la espectroteca de referencia de minerales producto de la meteorización de piritas (Crowley et al., 2003). C: Espectros en los que se ha eliminado el continuo, de los espectros Hymap de las unidades geológicas cartografiadas.

Figure 2.8. Layers of data product of an SDA-processed Hymap image (only VIS channels) identified by wavelength. The red wavelength labels correspond to non-zero information channels.

Figura 2.8. Capas de datos producto de una imagen Hymap sometida a Derivadas Espectrales Avanzadas (SDA) (sólo canales en el intervalo de longitudes de onda del visible VIS) identificados por su longitud de onda. Las capas identificadas en rojo corresponden a canales con información distinta de cero.

Figure 2.9. Spectra after continuum removal of Hymap geological units and reference minerals diagnosed as dominant on the corresponding geological unit with the reference spectra library on pyrite weathering products (Crowley et al., 2003).

Figura 2.9. Espectros después de eliminar el continuo, de las imágenes Hymap para las unidades geológicas cartografiadas, $y$ de los minerales de referencia 
diagnosticados como dominantes para cada unidad geológica con la espectroteca de minerales de oxidación de pirita de referencia (Crowley et al., 2003).

Figure 2.10. Linear regression between the wavelength of the critical absorption features versus the absorption parameters derived from the continuum removal of Hymap spectra of the geological units.

Figura 2.10. Regresión lineal entre las longitudes de onda de las absorciones características y los parámetros de absorción derivados de la eliminación del continuo en los espectros Hymap correspondientes a las unidades geológicas.

\section{CHAPTER 3}

Figure 3.1. Location of domains within the Sotiel mine site along the bank of the Odiel River.

Figura 3.1. Situación de ambientes estudiados en la mina de Sotiel a orillas del río Odiel.

Figure 3.2. Dam of ashes. A, B and C: Maps compiled from Hymap data on the minerals product of oxidation and dehydration of sulphide sludge, on the three available flights on the northern ashes dam. Increasing reddish colours suggest intense oxidation. Bluish and greenish colour concentrate on hydrated areas.

Figura 3.2. Balsa de cenizas. A, B y C: Mapas elaborados con datos Hymap de minerales producto de oxidación y deshidratación de lodos de sulfuros, en los tres vuelos disponibles sobre la balsa de cenizas septentrional. El predominio de colores rojizos indica oxidación intensa. Los colores azulados y verdosos se concentran en zonas con sulfatos hidratados.

Figure 3.3. Dam of ashes. A: Field spectra measured in several locations of the dam of ashes. B: Detail of small hydrated sulphate whitish growth in a haematitic crust. C: Whitish hydrated sulphate around an obstacle in the dominantly reddish haematitic crust.

Figura 3.3. Balsa de cenizas. A: Espectros de campo tomados en varios puntos de la balsa de cenizas. B: Detalle de crecimiento de sulfatos hidratados blancos sobre una costra hematítica rojiza. C: Sulfato blanquecino rodeando un obstáculo sobre costras hematíticas rojizas. 
Figure 3.4. Dam of ashes. A: Hymap spectra of representative units in 2005, 2008 and 2009. B: Detail of dominant hematite coating on the dam of ashes in 2005, with spectra in A. C: Detail of dry grass covering the recovered former dam of ashes in 2008, with spectra in A. D: Detail of soil covering the former dam of ashes in 2009, with spectra in A. E: Field spectra from the dry grass in 2008 covering the former dam of ashes. F: View of the dry grass covering the former dam of ashes in 2008, with operator measuring spectra.

Figura 3.4. Balsa de cenizas. A: Espectros Hymap de cubiertas representativas en 2005, 2008 y 2009. B: Detalle de una costra predominantemente hematítica en la balsa de cenizas en 2005, con espectro correspondiente en A. C: Detalle de hierba seca que crece sobre la balsa de cenizas rehabilitada en 20o8, con espectro en A. D: Detalle del suelo de la balsa de cenizas en 2009, con espectro en A. E: Espectro de campo de la hierba seca sobre la balsa de cenizas en 2008. F: Vista de la hierba seca cubriendo la balsa de cenizas en 2008, con un operador midiendo espectros.

Figure 3.5. Mine dump by the river. A, B and C: Maps compiled from Hymap data on the minerals product of oxidation and dehydration of sulphide sludge, on the three available flights on the old mine works by the river. Increasing reddish colours suggest intense oxidation. Bluish and greenish colour concentrates on hydrated areas. D: Typical terraced dump. E: Detail of mud pond in the dumps (coloured cyan on the maps, copiapite, red circles). F: Slopes on the dumps by the river in 2009, with bursts of greenish melanterite among oxidized coatings on the slopes.

Figura 3.5. Escombrera a orillas del río. A, B y C: Mapas elaborados con datos Hymap de minerales producto de oxidación y deshidratación de lodos de sulfuros, en los tres vuelos disponibles. El predominio de colores rojizos indica oxidación intensa. Los colores azulados y verdosos se concentran en zonas con sulfatos hidratados. D: Escombrera con geomorfología típica en terrazas. E: Detalle de balsa de lodos en las escombreras (cartografiada en añil en los mapas, copiapita, círculos rojos). F: Taludes en las escombreras a orillas del río en 2009, con afloramientos de melanterita verdosa en grietas de las costras predominantemente oxidadas en los taludes.

Figure 3.6. Mine dumps by the river. A: Spectra from Hymap areas mapped in June 2005 (Figure 3.5A), arranged on a precipitation and oxidation sequence. The colour coding follows the trend of the key from figure 3.2 , but changes are made for line 
identification clarity. B: Field spectra measured with an ASD Spectrometer in June 2005. C: Laboratory spectra on samples collected along 2006 on locations guided by Hymap mapping.

Figura 3.6. Escombreras a orillas del río. A: Espectros Hymap de las áreas cartografiadas en Junio de 2005 (Figura 3.5A), ordenados según la secuencia de precipitación a partir de lodos. Los colores asignados se inspiran en la leyenda del mapa de la figura 3.2, con cambios para mejorar la visión sobre fondo blanco. B: Espectros medidos con un espectrómetro ASD en Junio de 2005. C: Espectros de laboratorio en muestras recogidas en 2006 en puntos sugeridos por las cartografias realizadas con imágenes Hymap.

Figure 3.7. Mine dumps by the river. A: Spectra from Hymap areas mapped in August 2008 (Figure 3.5B), arranged on a precipitation and oxidation sequence. The colour coding follows the trend of the key from figure 3.2, but changes are made for line identification clarity.

Figura 3.7. Escombreras a orillas del río. A: Espectros de imágenes Hymap de las áreas cartografiadas en Agosto de 2008 (Figura 3.5B), según la secuencia de precipitación y oxidación de piritas. Los colores asignados se inspiran en la leyenda del mapa de la figura 3.2, con cambios para mejorar la visión sobre fondo blanco.

Figure 3. 8: Mine dumps by the river. A: Spectra from Hymap areas mapped in August 2009 (Figure 3.5C ), arranged on a precipitation and oxidation sequence. The colour coding follows the trend of the key from figure 3.2, but changes are made for line identification clarity. B: Field spectra measured with an ASD Spectrometer in August 2009 in the flat tops of dumps. C: Field spectra measured with an ASD Spectrometer in August 2009 in the bottom of dumps.

Figura 3.8. Escombreras a orillas del río. A: Espectros de imágenes Hymap en las áreas cartografiadas en Agosto de 2009 (Figura 3.5C), según la secuencia de precipitación y oxidación de piritas. Los colores asignados se inspiran en la leyenda del mapa de la figura 3.2, con cambios para mejorar la visión sobre fondo blanco. $B$ : Espectros de campo medidos con un espectrómetro ASD en Agosto de 2009 en las zonas planas al pie de las escombreras.

Figure 3.9. The mill tailings dam. A, B and C: Maps compiled from Hymap data on the minerals product of oxidation and dehydration of sulphide sludge, on the three 
available flights on the southern mill tailings dam. Bluish and greenish colours concentrate on comparatively hydrated areas. Orange and dark red colour corresponds to oxidised end members. Dark blue is acid water stored behind the wall of the dam. Red arrows are locations of mud supply. D, E and F: Panoramic view of the mill tailings dam in the corresponding years 2005, 2008 and 2009.

Figura 3.9. La balsa de lodos. A, B y C: Mapas elaborados con datos Hymap de minerales producto de oxidación y deshidratación de lodos de sulfuros, en los tres vuelos disponibles. El predominio de colores rojizos y anaranjados indica oxidación intensa. Los colores azulados y verdosos se concentran en zonas con sulfatos hidratados. El agua almacenada detrás de la pared de la balsa se colorea de azul oscuro. Las flechas rojas indican los puntos de aporte de lodos. D, E y F: Vista panorámica de la balsa de lodos en los años correspondientes a los mapas, 2005, 2008 y 2009.

Figure 3.10. The mill tailings dam. A: Spectra from Hymap areas mapped in June 2005. B: Spectra from Hymap areas mapped in August 2008. C: Spectra from Hymap areas mapped in and August 2009. Spectra are arranged on a precipitation and oxidation sequence. The colour coding follows the trend of the key from figure 3.2, but changes are made for line identification clarity.

Figura 3.10. La balsa de lodos. A: Espectros de imágenes Hymap en las áreas cartografiadas en Junio de 2005. B: Espectros de imágenes Hymap en las áreas cartografiadas en Agosto de 2008. C: Espectros de imágenes Hymap en las áreas cartografiadas en Agosto de 2009. Los espectros se ordenan según la secuencia de minerales de precipitación y oxidación de piritas. Los colores asignados se inspiran en la leyenda del mapa de la figura 3.2, con cambios para mejorar la visión sobre fondo blanco.

Figure 3.11. The ore processing plant and neighbourhood. A, B and C: Maps compiled from Hymap data on the minerals product of oxidation and dehydration of products of iron sulphide weathering, on the three available flights. Bluish and greenish colours indicate hydrated sulphate. D, E and F: Panoramic view of the ore processing plant in the years 2005, 2008 and 2009.

Figura 3.11. La planta de tratamiento de menas y alrededores. A, B y C: Mapas elaborados con datos Hymap de minerales producto de oxidación y deshidratación de 
lodos de sulfuros, en los tres vuelos disponibles. Los colores azulados y verdosos se concentran en zonas con sulfatos hidratados. D, E y F: Vista panorámica de la planta de tratamiento de menas en los años 2005, 2008 y 2009.

\section{CHAPTER 4}

Figure 4.1. False Colour Composite with Hymap channels 11 (o,6029 $\mu \mathrm{m}), 35$ (0.9394 $\mu \mathrm{m})$ and $109(2.2103 \mu \mathrm{m})$ of the Las Herrerías mine site (Pyrite Belt, Huelva, Spain), and identification of water bodies according to the traditional mine operation.

Figura 4.1. Composición en Falso Color con los canales Hymap 11 (o,6o29 $\mu m$ ), 35

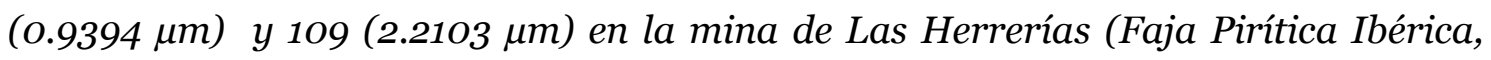
Huelva, España).

Figure 4.2. Sequence of hyperspectral image processing algorithms to build maps for water and dumps on the mine site from Hymap data.

Figura 4.2. Secuencia de algoritmos de tratamiento hiperespectral de imágenes para elaborar mapas cuerpos de agua y escombreras en la mina de las Herrerías con imágenes Hymap.

Figure 4.3. Sequence of hyperspectral image processing algorithms to produce maps for dumps and water on the mine site from Hyperion 144 channels after atmospheric correction through the empirical line model.

Figura 4.3. Secuencia de algoritmos de tratamiento hiperespectral de imágenes para elaborar mapas cuerpos de agua y escombreras en la mina de las Herrerías con imágenes Hyperion de satélite con 144 canales después de correcciones de ruido, y atmosféricas por el método de la corrección empírica.

Figure 4.4. A: Map of pyrite oxidation products from Hymap data on mine dumps with legend including all minerals of the reference spectral library (Crowley et al., 2003). B: Dumps at the mine site, with typical terraced geomorphology. C: Spectral library for the endmembers used to produce the map with Hymap 2009 data, with the corresponding mineralogical diagnosis.

Figura 4.4. A: Mapa de productos de oxidación de pirita elaborados con imágenes Hymap sobre escombreras según leyenda que incluye los minerales de la secuencia de oxidación de piritas (Crowley et al., 2003). B: Escombreras con relieve típicamente 
aterrazado. C: Espectroteca con los miembros extremos usados para elaborar el mapa con imágenes Hymap de 13 de Agosto de 2009, con su correspondiente diagnóstico mineralógico.

Figure 4.5. A: Map of pyrite oxidation products from Hyperion data from September 2006 on mine dumps with legend including all minerals of the reference spectral library (Crowley et al., 2003). B: Map of pyrite oxidation products from Hyperion data from August 2007 on mine dumps. C: Spectral library for the endmembers used to produce the map with Hyperion 2006 data, with the corresponding colour coded mineralogical diagnosis following legend. D: Spectral library for the endmembers used to produce the map with Hyperion 2007 data, with the corresponding colour coded mineralogical diagnosis following legend.

Figura 4.5. A: Mapa de productos de oxidación de piritas elaborado con imágenes Hyperion de Septiembre de 2006 sobre escombreras, con leyenda que incluye los minerales de la secuencia de oxidación de piritas (Crowley et al., 2003). B: Mapa de productos de oxidación de piritas de imágenes Hyperion de Agosto de 2007 en escombreras. C: Espectroteca de miembros extremos usados para elaborar el mapa con imágenes Hyperion de 2006, con el correspondiente diagnóstico mineralógico según leyenda. D: Espectroteca de miembros extremos usados para elaborar el mapa con imágenes Hyperion de 2007, con el correspondiente diagnóstico mineralógico según leyenda.

Figure 4.6. Field spectra on waste on flat surfaces of mine dumps identified as colour coded legend below, and mineralogical diagnosis according to pyrite oxidation reference library (Crowley et al., 2003). A: Dominant slate gravel with several grain sizes, pebbles and crusts on locations with lithologies shown on pictures. B: Gravel with variable lithologies and grain sizes, comparatively more oxidised than dominant slaty gravel in A, on locations with lithologies shown on pictures.

Figura 4.6. Espectros de campo en residuos en superficies planas altas de las escombreras, y diagnóstico mineral según la espectroteca de referencia de minerales de oxidación de piritas (Crowley et al., 2003). A: Grava con predominio de granos de pizarra con distintos tamaños de grano, cantos y costras, espectros medidos en las superficies fotografiadas. B: Grava con litologías y tamaños de granos variados, comparativamente más oxidados que las gravas predominantemente pizarrosas en A, espectros medidos en las superficies fotografiadas. 
Figure 4.7. Field spectra on waste on slopes of mine dumps, and mineral diagnosis according to pyrite oxidation reference library (Crowley et al., 2003). A: Dominant oxidised boulders with several lithologies and grain sizes on locations with lithologies shown on pictures. B: Boulders of dominant slate with variable grain sizes, on locations with lithologies shown on pictures.

Figura 4.7. Espectros de campo en residuos en taludes de escombreras, y diagnóstico mineral según la espectroteca de referencia de minerales de oxidación de piritas (Crowley et al., 2003). A: Cantos predominantemente oxidados de distintas litología y tamaños, espectros medidos en las superficies fotografiadas. B: Cantos predominantemente pizarrosos con tamaños de grano variados, espectros medidos en las superficies fotografiadas.

Figure 4.8. A. Dry mill tailings ponds. B: Typical geomorphology of dumps with terraces, and ponds on low flattened spaces. C: Field spectra on waste on mill tailings ponds, and mineral diagnosis according to the pyrite oxidation reference library (Crowley et al., 2003) on locations with lithologies shown on pictures.

Figura 4.8. A: Balsas de lodos secas. B: Escombreras con geomorfología típica en terrazas, y balsas en las depresiones aplanadas. C: Espectros de campo en residuos de las balsas de lodos, con diagnóstico mineral según la espectroteca de referencia de minerales de oxidación de piritas (Crowley et al., 2003), medidos en superficies fotografiadas.

Figure 4.9. A: Map of water bodies compiled from Hymap data. B: View of the "copper" pond. C: Spectra from Hymap data on the mine water bodies. D: Spectra from Hymap data on the water supply dams.

Figura 4.9. A: Mapa de cuerpos de agua elaborado con imágenes Hymap. B: Vista de la "balsa de cobre". C: Espectros de imágenes Hymap en los cuerpos de agua de las cortas de la mina. D: Espectros de imágenes Hymap en los embalses de abastecimiento de agua cercanos.

Figure 4.10. A: Map compiled from Hyperion 2006 for water bodies. B: Map compiled from Hyperion 2007 for water bodies. C: Spectra of water bodies from Hyperion 2006 data. D: Spectra of water bodies from Hyperion 2007 data. 
Figura 4.10. A: Mapa de cuerpos de agua elaborado con imágenes Hyperion de 2006. B: Mapa de cuerpos de agua elaborado con imágenes Hyperion de 2007. C: Espectros de cuerpos de agua de datos Hyperion 2006. D: Espectros de cuerpos de agua de datos Hyperion 2007.

Figure 4. 11. Field spectra from mine water bodies and the clean water supply dam.

Figura 4.11. Espectros de campo en las balsas de agua de las cortas mineras, y en el embalse de abastecimiento de agua.

\section{CHAPTER 5}

Figure 5.1. Precipitation and temperature records during the time span previous to the imagery used in the study (data provided by the National Weather Institute of Spain (AEMET, Agencia Estatal de Meteorología, Spain), Resumen Anual Climatológico de os años 2004-2009, www.aemet.es).

Extremely wam: The temperatures exceed the maximum recorded for the reference period 1961-1990.

Very warm: The temperatures recorded are within the $20 \%$ of the span of the warmest years of the reference period 1961-1990.

Warm: The temperatures recorded are within $20 \%$ and $40 \%$ of the warmest years reference period 1961-1990.

Normal: The temperatures recorded are within $40 \%$ and $60 \%$ of the reference period 1961-1990.

Cold: The temperatures recorded are within $60 \%$ and $80 \%$ of the reference period 1961-1990.

Very cold: The temperatures recorded are within the $80 \%$ of the reference period 1961-1990.

Extremely cold: The temperatures recorded do not reach the minimum value recorded during the reference period $1961-1990$.

Figura 5.1. Precipitación y temperatura estacionales durante el periodo de tiempo anterior a las imágenes Hymap disponibles (Agencia Estatal de Meteorología, Resúmenes Estacionales Climatológicos, www.aemet.es).

EC=Extremadamente Cálido: Las temperaturas sobrepasan el valor máximo registrado en el periodo de referencia $1971-2000$.

MC=Muy cálido: $f<20 \%$. Las temperaturas registradas se encuentran en el intervalo correspondiente al $20 \%$ de los años más cálidos.

C = Cálido: $20 \% \leq f<40 \%$.

N=Normal: $40 \% \leq 60 \%$. Las temperaturas registradas se sitúan alrededor de la mediana.

F = Frío: $60 \% \leq f<80 \%$.

MF =Muy Frío: $f \geq 80 \%$.

$\boldsymbol{E F}=$ Extremadamente frío: Las temperaturas no alcanzan el valor mínimo registrado en el periodo de referencia $1971-2000$. 
Figure 5.2. Spectra from Hymap imagery from the endmembers used to build the geological map on Figure 2.5D. Right below is the mineralogical diagnosis using the pyrite weathering minerals library as reference (Crowley et al., 2003) for the spectra on the graph.

Figura 5.2. Espectros de las imágenes Hymap en los miembros extremos correspondientes a unidades geológicas utilizados para elaborar el mapa de la figura 2.5D. Abajo a la derecha, leyenda con los diagnósticos mineralógicos con productos de meteorización de piritas realizados con la espectroteca mineral de referencia (Crowley et al., 2003) para los mismos espectros.

Figure 5.3. Field spectra on detritic materials at the bottom of the channel. A: Tributary to the Odiel River clean from contamination by acid mine drainage precipitates. B: bottom of the channel detrital materials on the contaminated Odiel River. Mineralogical diagnose of coatings using a laboratory reference spectral library (Crowley et al., 2003).

Figura 5.3. Espectros de campo medido en sedimentos detríticos en el fondo del canal del río. A: Sedimentos en un afluente al río Odiel sin contaminación por precipitados de aguas ácidas. B: Sedimentos del fondo del río Odiel contaminados por precipitados de aguas ácidas. Diagnóstico mineralógico de las costras que cubren los sedimentos con la espectroteca de referencia de laboratorio (Crowley et al., 2003).

Figure 5.4. Mosaic with the ten Hymap flight lines covering the flow path of the Odiel River in 2008, with test sites and locations and dates of field spectra.

Figura 5.4. Mosaico con las diez líneas de vuelo del sensor Hymap que recorren el curso del río Odiel en 2008, con expresión de las zonas de estudio seleccionadas para hacer cartografias detalladas, y los puntos y fechas de toma de medidas espectrales en campo.

Figure 5.5. The head of the river. A: Map compiled from Hymap images in 2008. B: Map compiled from Hymap images in 2009. C: Hymap spectra from the geological units mapped in 2008. D: Hymap spectra from the geological units mapped in 2009.

Figura 5.5. La cabecera del río. A: Mapa elaborado con imágenes Hymap de 4 de Agosto de 2008. B: Mapa elaborado con imágenes Hymap de 14 de Agosto de 2009. 
C: Espectros Hymap de las unidades geológicas cartografiadas en 2008. D: Espectros Hymap de las unidades geológicas cartografiadas en 2009.

Figure 5.6. Daily rainfall records during the time span previous to the Hymap flights (data provided by the National Weather Institute of Spain (AEMET, Agencia Estatal de Meteorología, Spain, www.aemet.es).

Figura 5.6. Datos diarios de precipitación durante el periodo de tiempo anterior a los vuelos Hymap (Agencia Estatal de Meteorología, www.aemet.es).

Figure 5.7. The river at the first intense contamination input (Puente de los Cinco Ojos). A: Map of coatings over river sediments compiled from Hymap data on 4th August 2008. B: Map of coatings over river sediments compiled from Hymap data on 13th August 2009. Legend including all minerals of the reference spectral library on minerals associated with iron sulphide mine waste products (Crowley et al., 2003).

Figura 5.7. El río en el punto del primer aporte intenso de contaminación (Puente de los Cinco Ojos). A: Mapa de costras depositadas sobre los sedimentos del río elaborado con datos Hymap del 4 de Agosto de 2008. B: Mapa de costras depositadas sobre los sedimentos del río elaborado con datos Hymap del 14 de Agosto de 20o9. La leyenda incluye los minerales de la espectroteca de referencia de minerales de meteorización de piritas (Crowley et al., 2003).

Figure 5.8. The first input of intensely contaminated water in the river (Puente de los Cinco Ojos). A: Map of deep water with different $\mathrm{pH}$ built from Hymap data on the $4^{\text {th }}$ August 2008. B: Map of water and mud from Hymap data on the $4^{\text {th }}$ August 2008. C: Map of deep water built from Hymap data on the $13^{\text {th }}$ August 2009. D: Map of water and mud built from Hymap data on the $13^{\text {th }}$ August 2009.

Figura 5.8. El río en el punto del primer aporte intenso de contaminación (Puente de los Cinco Ojos). A: Mapa de agua profunda con distinto $p H$ elaborado con datos Hymap del 4 de agosto de 20o8. B: Mapa de agua y barro elaborado con datos Hymap del 4 de Agosto de 20o8. C: Mapa de agua profunda elaborado con imágenes Hymap del 13 de Agosto de 2008. D: Datos de agua y barro elaborado con datos Hymap del 13 de Agosto de 2009.

Figure 5.9. A. Hymap spectra of the endmembers used to build the map of water and mud (figure 8B). B. Table summarizing relevant spectral features on the spectra above. 
Figura 5.9. Espectros de imágenes Hymap de los miembros extremos usados para elaborar el mapa de agua y barro (Figura 8B). B: Tabla que resume los rasgos espectrales más importantes de los espectros anteriores.

Figure 5.10. Bridge on the road Calañas-Valverde del Camino. Maps of coatings over river sediments diagnosed with the reference spectral library (Crowley et al., 2003). Legend as Figure 5.7. A: Map of coatings over river sediments compiled from Hymap data in 2008. B: Map of coatings over river sediments compiled from Hymap data in 2009.

Figura 5.10. Puente sobre el río Odiel en la carretera Calañas-Valverde del Camino. Mapas de costras precipitadas sobre sedimentos fluviales diagnosticados mineralógicamente con la espectroteca de referencia (Crowley et al., 2003). Leyenda según la Figura 5.7. A: Mapa de costras sobre sedimentos fluviales elaborados con imágenes Hymap de 4 de Agosto de 20o8. B: Mapa de costras sobre sedimentos fluviales elaborados con imágenes Hymap de 13 de Agosto de 2009.

Figure 5.11. The mine site works in the middle course (Sotiel). Maps of coatings over river sediments diagnosed with the reference spectral library (Crowley et al., 2003). Legend as Figure 5.7. A: Map of coatings over river sediments compiled from Hymap data in 2005. B: Map of coatings over river sediments compiled from Hymap data in 2008. C: Map of coatings over river sediments compiled from Hymap data in 2009.

Figura 5.11. Las escombreras de las minas en el curso medio a orillas del río Odiel (Sotiel). Mapas de costras precipitadas sobre sedimentos fluviales diagnosticados mineralógicamente con la espectroteca de referencia (Crowley et al., 20o3). Leyenda según la Figura 5.7. A: Mapa de costras sobre sedimentos fluviales de 17 de Junio de 2005. B: Mapa de costras sobre sedimentos fluviales de 4 de Agosto de 2008. C: Mapa de costras sobre sedimentos fluviales de 13 de Agosto de 2009.

Figure 5.12. The typical knick-point pattern (Wall south of Sotiel). Maps of coatings over river sediments diagnosed with the reference spectral library (Crowley et al., 2003). Legend as Figure 5.7. A: Map of coatings over river sediments compiled from Hymap data in 2005. B: Map of coatings over river sediments compiled from Hymap data in 2008. C: Map of coatings over river sediments compiled from Hymap data in 2009. 
Figura 5.12. El ejemplo típico de ruptura de pendiente (presa al sur de Sotiel). Mapas de costras precipitadas sobre sedimentos fluviales diagnosticados mineralógicamente con la espectroteca de referencia (Crowley et al., 2003). Leyenda según la Figura 5.7. A: Mapa de costras sobre sedimentos fluviales elaborado con imágenes Hymap de 17 de Junio de 2005. B: Mapa de costras sobre sedimentos fluviales elaborado con imágenes Hymap de 4 de Agosto de 20o8. C: Mapa de costras sobre sedimentos fluviales elaborado con imágenes Hymap de 13 de Agosto de 2009.

Figure 5.13. The linear encased flow path (Fuente de la Corcha). Maps of coatings over river sediments diagnosed with the reference spectral library (Crowley et al., 2003). Legend as Figure 5.7. A: Map of coatings over river sediments compiled from Hymap data on $4^{\text {th }}$ August 2008. B: Map of coatings over river sediments compiled from Hymap data on $24^{\text {th }}$ August 2009.

Figura 5.13. El curso del río encajado con trazo linear (Fuente de la Corcha). Mapas de costras precipitadas sobre sedimentos fluviales diagnosticados mineralógicamente con la espectroteca de referencia (Crowley et al., 2003). Leyenda según la Figura 5.7. A: Mapa de costras sobre sedimentos fluviales elaborados con imágenes Hymap de 4 de Agosto de 2008. B: Mapa de costras sobre sedimentos fluviales elaborados con imágenes Hymap de 13 de Agosto de 2009.

Figure 5.14. The entrance to the estuary. Maps of coatings over river sediments diagnosed with the reference spectral library (Crowley et al., 2003). Legend as Figure 5.7. A: Map of coatings over river sediments compiled from Hymap images in 2008, with sections according to grain size on sediments (Riaza et al., 2012). B: Map of coatings over river sediments compiled from Hymap images in 2009. C: Map of coatings over river sediments of the area of boulders in 2008. D: Map of coatings over river sediments of the area of boulders in 2009. E: Map of coatings over river sediments of the area of sands in 2008. F: Map of coatings over river sediments of the area of sands in 2009. G: Map of coatings over river sediments of the area of channels and mud in 2008. H: Map of coatings over river sediments of the area of channels and mud in 2009.

Figura 5.14. La entrada en el estuario. Mapas de costras precipitadas sobre sedimentos fluviales diagnosticados mineralógicamente con la espectroteca de referencia (Crowley et al., 2003). Leyenda según la Figura 5.7. A: Mapa de costras sobre sedimentos fluviales elaborados con imágenes Hymap de 4 de Agosto de 2008, 
con expresión de subescenas cartografiadas en función del tamaño de grano predominante de los sedimentos (Riaza et al., 2012). B: Mapa de costras sobre sedimentos fluviales elaborados con imágenes Hymap el 13 de Agosto de 20o9. C: Mapa de costras sobre sedimentos fluviales en el área de predominio de cantos elaborados con imágenes Hymap de 4 de Agosto de 20o8. D: Mapa de costras sobre sedimentos fluviales en el área de predominio de cantos elaborados con imágenes Hymap de 13 de Agosto de 20o9. E: Mapa de costras sobre sedimentos fluviales en el área de predominio de arenas elaborados con imágenes Hymap de 4 de Agosto de 20o8. F: Mapa de costras sobre sedimentos fluviales en el área de predominio de arenas elaborados con imágenes Hymap de 13 de Agosto de 2009. G: Mapa de costras sobre sedimentos fluviales en el área de predominio de limos y agua elaborados con imágenes Hymap de 4 de Agosto de 20o8. H: Mapa de costras sobre sedimentos fluviales en el área de predominio de limos y agua elaborados con imágenes Hymap de 13 de Agosto de 2009. 


\section{ABSTRACT}

Monitoring of mine waste on sulphide deposits through hyperspectral remote sensing data contributes to predicting surface water quality quantitatively estimating acid drainage and metal contamination on a yearly basis. The mineralogy of surface crusts loaded with highly soluble salts is a record of available humidity and temperature along the year. A temporal monitoring of salt efflorescence on mine wastes at a mine site in the Iberian Pyrite Belt (Spain) has been mapped in this work using hyperspectral airborne Hymap data. Climate change estimations are made based on oxidation stages derived from well-known sequences of minerals tracing sulphides oxidation intensity, using archive spectral libraries. Therefore, mine waste weathering products of sulphide mapped from airborne hyperspectral remote sensing data can be used as a short-term record of climate change, providing a useful tool for assessing environmental geoindicators in semi-arid areas.

Hyperspectral remote sensing deals with airborne and spaceborne imaging spectrometers which have a similar spectral resolution to the field and laboratory instruments. A large number of channels in two dimensions require image processing procedures able to manage high dimensionality on data. The main technical features of the Hymap airborne and Hyperion spaceborne hyperspectral sensors used in this study are described. The pre-processing chain to convert raw data to reflectance on both sensors is drafted. The interpretation of hyperspectral remote sensing requires specific algorithms able to manage high dimensional data. The image processing methods to extract information are described, and the sequence of algorithms used to produce maps, both on mine sites and river paths.

The mineralogical identification capability of algorithms to produce maps based on archive spectral libraries is discussed. Trends of mineral growth differ spectrally over time according to the geological setting. Subtle mineralogical changes are described using the spectral response and their meaning as indicators of pyrite oxidation intensity on mine waste piles, pyrite mud tailings and river sediments. A new exploration method, the Automated Modified Gaussian Model, intends to estimate further spectral variability explaining the geological meaning of the Hymap spectra associated to the units of river sediments mapped. 
Hyperspectral low spatial resolution Hyperion data are used to map mine waste from massive sulphide ore deposits, mostly abandoned, on the Iberian Pyrite Belt. Hymap high spatial resolution data are used for crossed interpretation. Mine dams, mill tailings and mine dumps in a variable state of pyrite oxidation are recognizable. Ponds of acid water in the mine sites are spectrally outstanding and, with simple image processing procedures, mappable. In addition, acid water with different chemical composition is mappable with hyperspectral data, whether of high or low spatial resolution. A sequence of hyperspectral image processing algorithms used to produce the maps is suggested.

The Odiel River carries acidic water originating from mine waste contamination, including massive sulfide ore deposits. Acid Mine Drainage processes taking place in numerous mine sites drain acid and contaminated water to the river, causing acid $\mathrm{pH}$, and increasing the transport of heavy metals and other contaminating substances. Changing climatic conditions control both the geochemical evolution of secondary minerals that precipitate over the river sediments and the hydrodynamic regime of the river, as much as flow rate.

Mapping contamination products from sulphide mine waste on a river flow path with hyperspectral data involves a careful mapping of the river sediments and minor topographical features changing the water dynamics. The minor topography provides the favourable locations to monitor contaminant mineral development. The use of a reference mineralogical spectral library, developed in the laboratory, requires a careful geological context evaluation to provide efficient environmental information on contamination parameters. Based on the hyperspectral analyses of critical spectral features, river locations that may be crucial for tracing significant, future contaminant fluctuations were identified.

The observations of the proposing group point to spectral and geomorphological indicators which can be monitored through image processing supported by field and laboratory spectral data, on a repeatable basis. Hyperspectral image analysis is included on the methods selected by the Joint Research Centre of the European Community (Yspra, Italy) to study abandoned mine sites to assess the enforcement of the European Mine Waste Directive, published in 2006. The pyrite belt in Andalucía has been selected as one of the core mission test sites for the PECOMINES II program 
(Cracow, November 2005) using imaging spectroscopy. The use of this technique as a monitoring tool aims to be implemented by the Environmental Net of Andalucía (REDIAM, Spain).

\section{Keywords}

Imaging spectroscopy, hyperspectral remote sensing, geology, pyrite weathering, acid mine drainage, climate variability, river geomorphology, temporal monitoring. 


\section{RESUMEN}

El seguimiento de residuos mineros de yacimientos de sulfuros masivos con datos de teledetección hiperespectral contribuye a predecir la calidad del agua de escorrentía. Permite hacer estimaciones cuantitativas de drenaje ácido de mina, y de contaminación por disolución de metales con una periodicidad anual para el caso que se estudia. La mineralogía de las costras que concentran sales muy solubles, es un registro de la humedad y temperatura ambientales durante el año precedente. En este trabajo, se ha realizado un seguimiento temporal de las eflorescencias salinas sobre los residuos mineros en las minas abandonadas de la Faja Pirítica Ibérica (España) con cartografías extraídas de datos aeroportados hiperespectrales Hymap. Se realizan estimaciones de variabilidad climática basándose en las etapas de oxidación que se deducen de secuencias conocidas de evolución mineralógica por procesos de oxidación en sulfuros de hierro, que indican la intensidad de los procesos de oxidación. Para ello se usan espectrotecas de referencia elaboradas en el laboratorio. De este modo, los productos de meteorización de piritas que aparecen en residuos mineros observados con imágenes hiperespectrales pueden convertirse en un registro de variabilidad climática a corto plazo, convirtiéndose en un instrumento útil como geoindicadores en zonas semiáridas.

Los datos de teledetección hiperespectral, tanto aeroportados como en sensores embarcados en satélite, recogen información espectral sobre la superficie de la tierra con una resolución espectral continua, asimilable a los espectros proporcionados por espectrómetros de campo o laboratorio. Cada imagen cuenta con un número elevado de datos en dos dimensiones sobre la superficie de la tierra, que requieren algoritmos de tratamiento digital especiales, capaces de explorar datos con grandes dimensiones. En este trabajo se describen las características de los sensores utilizados, y se describe la cadena de tratamientos que se aplican a los datos brutos antes de la fase de interpretación. También se describe la secuencia de algoritmos utilizados en la extracción de información geológica para la producción de mapas, tanto en residuos mineros como en el cauce del río.

El uso de espectrotecas de referencia con algoritmos cartográficos produce resultados variables, cuyas limitaciones se describen. Las tendencias en la evolución de crecimiento mineral difieren según el sustrato geológico en el que se desarrollan. Se 
describen cambios mineralógicos sutiles en función de la respuesta espectral, y su significado como indicadores de la intensidad de la oxidación de piritas sobre escombreras, balsas de lodos y sedimentos fluviales. Se ensaya un nuevo método de exploración, el Modelo de Modificadas Gaussianas Automáticas, que intenta evaluar la variabilidad espectral en función del significado geológico de los espectros de imágenes Hymap asociados a sedimentos fluviales.

El río Odiel lleva agua ácida procedente de la contaminación de los residuos mineros de las muchas minas de sulfuros masivos de su cuenca de drenaje. El caudal del río, además de ser ácido, transporta en disolución metales pesados cuya concentración aumenta por la acidez de las aguas. La evolución geoquímica de las costras que se precipitan sobre los sedimentos del río a partir de agua ácida es función del clima, que define el caudal y el régimen hidrodinámico del río.

La cartografía de las sustancias que aparecen en los sedimentos fluviales como consecuencia de la contaminación del río por los residuos de yacimientos de sulfuros masivos, exige una cartografía previa de los sedimentos del río, y de la microgeomorfología que determina cambios menores en el régimen del flujo del agua. Esta microtopografía proporciona entornos favorables para el seguimiento de las sustancias contaminantes. El empleo de una espectroteca de referencia, elaborada en el laboratorio, requiere una evaluación cuidadosa del contexto geológico si se pretende proporcionar una información ambiental representativa de los parámetros que se asocian a la contaminación. Según el tratatamiento digital de imágenes hiperespectrales basado en rasgos de absorción críticos, se identifican puntos en el curso del río que pueden ser claves para el seguimiento de indicadores de contaminación.

El autor propone indicadores espectrales y geomorfológicos que pueden seguirse con tratamiento de imágenes apoyado en espectros tomados en campo y laboratorio, de manera repetible. El empleo de análisis hiperespectral en la Faja Pirítica Ibérica andaluza se ha incluido entre las cuatro zonas piloto del núcleo de la misión PECOMINES II (Cracovia, Noviembre 2005) a propuesta de la Junta de Andalucía respaldada por los investigadores participantes (CGL2007-60004/CLI). El Joint Research Centre (JRC, Yspra, Italia) desarrolla el programa PECOMINES, un foro de discusión sobre métodos de estudio en minas abandonadas que respalda la aplicación de la Directiva Europea de Residuos Mineros, publicada en marzo de 2006. Pretende 
utilizarse como herramienta de seguimiento en un futuro la Red de Información Ambiental de Andalucía (REDIAM, Junta de Andalucía).

\section{Palabras clave}

Espectroscopía de imágenes, teledetección hiperespectral, geología, meteorización de piritas, drenaje ácido de mina, variabilidad climática, geomorfología fluvial, seguimiento temporal. 


\section{GOAL AND OBJECTIVES}

This work aims to develop a monitoring system using hyperspectral data of the contamination produced by mine waste from iron sulphide ore deposits. The test site is the Iberian Pyrite Belt in SW Spain, a large outcrop of a thick sequence of vulcanosedimentary slate hosting complex sulphide mine sites.

Several objectives are pursued:

1. To find a spectral evaluation of the patterns in the environment of mine sites and river flow path collecting contaminants, and to establish a sequence of algorithms to produce maps summarizing the main pattern of contaminants, from hyperspectral imagery. The legend of the maps relies on the mineralogical diagnosis using a reference spectral library of the sequence of pyrite weathering products present throughout the contaminated areas. Non commercial algorithms are explored as tools to contribute to the spectral monitoring of the contamination.

2. To define a mapping sequence of algorithms revealing spectral trends on mine sites, that define environments with different mineralogical evolution. To describe this evolution based on a basic field spectral library and Hymap derived spectral library sets the basis for a systematic monitoring in mine sites.

3. To confront airborne Hymap and spaceborne Hyperion data to challenge the mapping capabilities of mine waste and water bodies in mine sites. The influence of the atmospheric correction methods in the hyperspectral image processing chain, the geomorphology of the mine site, and the mineralogical heterogeneity of the targets are tha main limiting parameters in the mineralogical diagnose of the surfaces in the maps.

4. To follow the mineralogical evolution in mine sites under human influence, or only climate influence. The maps are able to show the capabilities of hyperspectral data to detect changes in mine sites, whether under a recovery program, or abandoned mine areas changing only under the influence of the atmosphere. The maps are faithful witnesses of the industrial activities of cleaning of coatings, refilling of tailings and smoothing of dumps in a mine under recovery. The maps are also faithful to record climate changes if there is no other interference, through mineralogical changes responding to environmental humidity and temperature. 
5. To monitor contaminants in a river. Running water collects contaminants from mine waste. The Odiel River, flowing in a basin densely scattered by mine sites, is mapped to search parameters critical to monitor the contamination. The map of the sediments of the river helps to identify the sites which are geomorphologically favourable to concentrate contaminants suitable to be monitored by hyperspectral images. The spectral features of sediments and coatings of contaminating substances interact closely. The details of the spectral behaviour of land and water in the environment of the river are explained.

Therefore, the basics of the spectral trends of the contamination in the area intend to be described, and the main lines of the monitoring system using hyperspectral data intend to be drafted below. 


\section{CHAPTER 1}

\section{MINE TAILINGS AND ACID MINE DRAINAGE UNDER AN IMAGING SPECTROSCOPY VIEW: STATE OF THE ART}

\subsection{INTRODUCTION}

Sulphide ore deposits are abundant in the Pyrite Belt (SE Spain), and pyrite is present in significant quantities in mine waste in dumps and ponds. The massive polymetallic sulphides have been exploited for industrial use for over 5000 years, as evidenced by the presence of pyrite nodules in coastal sediments. Mud from ponds and solid waste weather rapidly to create a superficial hydrated sulphate crust via sulphide oxidation. Weathered crusts contain higher concentrations of heavy metals than unweathered mineral surfaces. Contamination from acid mine drainage is favoured by sandy soils and alluvial deposits at the bottom of topographically low areas, which absorb contaminating matter through drainage or slope sliding.

Imaging spectroscopy using reference spectral libraries is recognized as a suitable technique for the study of mine waste, and enables quick mineralogical identification, saving time and costs. In contrast, conventional methods require tedious sample collection and chemical analysis, followed by interpolation of results through spatial mapping methods (Swayze et al., 2000). Imaging spectroscopy also allows for mineralogical diagnoses of thin ephemeral crusts with significant concentrations of heavy metals, on surfaces which are inaccessible to direct observation (Plumlee, 1999), providing an invaluable tool for environmental assessment.

Climate is a major controlling factor of the growth and solubilisation of pyrite salts and other metallic sulphide mine waste. Most previous mine waste mapping studies using hyperspectral data have focused on the identification of environmental evidence for predicting the extent of heavy metal contamination and acid drainage in surface water and groundwater (Swayze et al., 2000; Zabcic et al., 2005; Zabcic, 2008). Maps produced from historic Hymap data of the area of study (Riaza et al., 2007, 2010a, 2010b) suggest that the mineralogical pattern within the mine waste and sediments is dependent on fluctuations in humidity and evaporation intensity, and could be used as 
a record of seasonal and annual climate changes. Later field and laboratory spectral investigations, which monitored mineralogical changes in mine waste from the end of the wet season through the dry season (Olias et al., 2004; Sarmiento et al., 2009), were in agreement with these observations (Riaza et al., 2011b).

Based on these results, the authors suggest variations on the spectral identification of pyrite mud weathering products, using spectral libraries developed with a geological context (Clark et al., 2007; Crowley et al., 2003), both on mine waste dumps and tailings, and river sediments (Riaza et al., 2006; 2012b; 2012a; 2011a). The geological and geomorphological influence of surfaces with pyrite oxidation products, or precipitation from acid water, on the spectral response was also evaluated. The maps produced from hyperspectral airborne or spaceborne sensors are the main summarizing tool. The work performed to date is part of a wider study whose aim is to develop a monitoring system which can provide predictions on water quality estimations, and can be operated by regulators in the future.

\subsection{THE HYPERSPECTRAL MONITORING TOOL}

The high spectral resolution of airborne and satellite spectrometers has enlarged the mapping capabilities of remote sensing data, widely developed with the use of AVIRIS data operating since 1987. Advances in data calibration and the development of algorithms able to extract information from a large amount of spatial and spectral data based on field spectra encouraged applications for environmental issues (Van der Meer and de Jong, 2001). Early focus on mine waste through the study of secondary minerals began concentrating initially on iron-bearing oxides and hydroxides (Farrand and Harsanyi, 1995). It soon expanded to secondary minerals related to mine waste weathering (Clark et al., 1998; Swayze et al., 1996; Levesque et al., 1997).

Minerals generating acid environments attracted the attention of the geological scientific community since they are highly mobile in the environment through solution in drainage water. The spectral behavior of pyrite and sulphate derived by oxidation and their solution properties were explored, and patterns of precipitation established and traced using remote sensing hyperspectral data (Swayze et al., 1998; 2000). The development of spectral libraries from field sites has favored the nearly automatic mapping of ephemeral mineral features related to acid mine drainage (Ong et al., 2002; Montero et al., 2002; Ong et al., 2003; Mars and Crowley, 2003; Sares et al., 2003). 
Detailed discussion of the spectral absorption features observed in the visible to shortwave infrared wavelength region of secondary iron oxide, iron hydroxide and iron sulphate hydrate minerals associated with sulphide-bearing mine wastes was made by Crowley et al. (2003), which provided the spectral library used as a reference in this paper. This is the starting point to explore the spectral behaviour of pyrite weathering products displayed on mine waste and drainages on the environments described in the following work.

\subsection{PYRITE MINE WASTE WEATHERING}

Metallic sulphide ore deposit mine sites in the area of study are nowadays undisturbed by industrial activity, yet are exposed to the atmospheric agents. Pyrite, the iron disulphide mineral, is then prone to oxidation rates mainly limited by atmospheric conditions. Pyrite oxidation is a complex process that proceeds rapidly when this mineral and other sulphides are exposed to air, releasing sulphate into water and lowering water $\mathrm{pH}$ values (Nordstrom and Alpers, 1999).

Soluble secondary salts are formed from the evaporation of acid-drainage waters. Efflorescent crusts are common on the surfaces and on the edges of natural and minedrainage streams and ponds (Sares et al., 2003). The mineralogy of the salt product can change with progressive evaporation of acid water (Nordstrom and Alpers, 1999). The greatest salt growth occurs when the growing crusts are replenished by acid water, such as a flowing drainage stream or waters wicked to the surface of mine waste dumps by capillary action (Plumlee, 1999). The soluble secondary salts can also form as sulphide weathering products that are in contact with atmospheric moisture.

As they are highly soluble, secondary salts form where sulphides have been exposed to weathering by oxygenated waters. Mine waste piles, mill tailings and mine workings are hosts for these minerals. Sulphide weathering in the Iberian Pyrite Belt mine sites seem to produce sulphate first by oxidation of the pyrite-rich ores followed by dissolution and precipitation involving a combination of oxidation, dehydration and neutralization reactions (Velasco et al., 2005).

Particles in finely milled ore and tailings have very high surface areas and abundant broken crystal edges. This enhances mineral reactivity relative to those of mined rock and waste rock (Plumlee, 1999). Oxidation rates on sulphide mine-waste dumps are six orders of magnitude higher than on granite piles. The pyrite oxidation reaction is highly 
exothermic, increasing the environmental temperature around mine waste significantly.

Rapid oxidation and evaporation of sulphides on mine waste produces iron-bearing sulphate and other metals as secondary minerals (Nordstrom and Alpers, 1999). A sequence of salts is established from a solution of pyrite, from early to later formed (Buurman, 1975; Alpers et al., 2003). Ferrous sulphate salts are found close to pyrite sources (melanterite $\mathrm{Fe}^{2+}\left(\mathrm{SO}_{4}\right) \cdot 7\left(\mathrm{H}_{2} \mathrm{O}\right)$, rozenite $\mathrm{Fe}^{2+}\left(\mathrm{SO}_{4}\right) \cdot 4\left(\mathrm{H}_{2} \mathrm{O}\right)$, szmolnokite $\mathrm{Fe}\left(\mathrm{SO}_{4}\right) \cdot \mathrm{H}_{2} \mathrm{O}$ ), whereas Ferric-bearing minerals (rhomboclase $\mathrm{HFe}^{3+}\left(\mathrm{SO}_{4}\right)_{2} \cdot 4\left(\mathrm{H}_{2} \mathrm{O}\right)$, voltaite, halotrichite $\left.\mathrm{Fe}^{2+} \mathrm{Al}_{2}\left(\mathrm{SO}_{4}\right)_{4} \cdot 22\left(\mathrm{H}_{2} \mathrm{O}\right)\right)$ can be considered hydrologic dead-ends, where most of the $\mathrm{Fe}^{2+}$ has had time to oxidize to $\mathrm{Fe}^{3+}$.

Based on laboratory experiments of evaporating acid mine waters, the paragenetic sequence seems as below (in Nordstrom et al., 1999, p.152, mentioning Buurman, 1975; Nordstrom, 1982 and C. Maenz, written communication 1995):

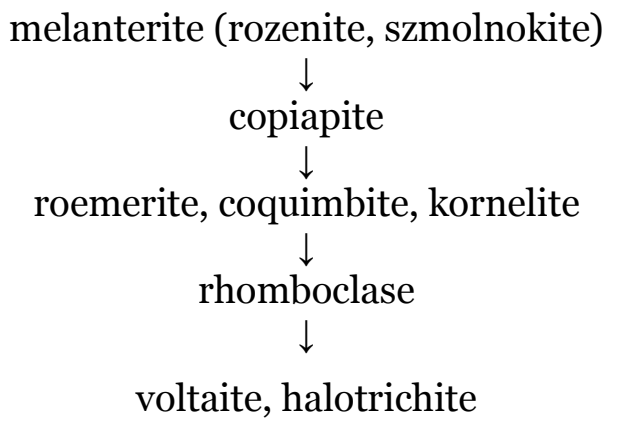

Further oxidation leads to the formation of schwertmannite $\left(\mathrm{Fe}^{3+}{ }^{+} 6 \mathrm{O}_{16}(\mathrm{OH})_{12}\left(\mathrm{SO}_{4}\right)_{2}\right)$ and the group of jarosite-alunite $\left(\left(\mathrm{SO}_{4}\right)_{2} \mathrm{KFe}_{3}(\mathrm{OH})_{6}-\mathrm{KAl}_{3}\left(\mathrm{SO}_{4}\right)_{2}(\mathrm{OH})_{6}\right)$. The mineralogy of oxidized zones on gossans is dominated by hematite $\left(\mathrm{Fe}_{2} \mathrm{O}_{3}\right)$, goethite $(\mathrm{FeO}(\mathrm{OH}))$ and jarosite $\left(\left(\mathrm{SO}_{4}\right)_{2} \mathrm{KFe}_{3}(\mathrm{OH})_{6}\right)$.

$$
\begin{gathered}
\text { schwertmannite } \\
\downarrow \\
\text { jarosite-alunite } \\
\downarrow \\
\text { hematite, goethite }
\end{gathered}
$$

\subsection{CLIMATE CONTROL}

Temperature and humidity control evaporation. In regions with a semi-arid climate where the water table is low and there are annual rainy and dry seasons, sulphate salt growth reaches a maximum at the end of the dry season. Then, the mineralogy of the 
precipitated salts is a record of available humidity and temperature throughout the year (Seal and Hammarstrom, 2003).

Sulphate salt products of pyrite oxidation are highly ephemeral, and washed by seasonally controlled storms. Rain and evaporation rates in areas with a semi-arid climate are restricted by the seasons on a yearly basis. Efflorescences are completely washed away during the sudden and heavy autumn rains, but not by light summer rain. They precipitate again during the dry season the following year in a well-known mineral sequence related to their dehydration state (Buurman, 1975). The whole sequence of pyrite oxidation minerals can be displayed on the surface of a mud pond within several weeks throughout the dry season in the area of study (Velasco et al., 2005).

This seasonally relative mineral dehydration process enables the system to be considered a rapidly changing geological environment which responds to atmospheric changes (Berger and Iams, 1996). The initial and final dehydration stage registered at the beginning and the end of the dry season is a record of evaporation intensity during the year, and, therefore, of the climate regime during the year. A yearly record of the spatial pattern of the sulphate salts is a geological record of the annual climate regime, if constantly monitored. This yearly change is established and constantly monitored by local water quality analysts (Olias et al., 2004).

\subsection{REGIONAL GEOLOGY AND CLIMATE}

The Iberian Pyrite Belt, in southwest Spain (Figure 1.1) is a wide outcrop hosting massive sulphide deposits generating acid mine drainage. Therefore, it is geologically suited for using hyperspectral image analysis.

Pyrite mining on the Iberian Pyrite Belt (Southwest Spain and Portugal) has a long history of at least $\approx 5000$ years (Leblanc et al., 2000). Massive sulphide deposits hosted on a Volcano-Sedimentary Complex, thick stratigraphical series of volcanic detrital origin, are widespread throughout the region (Almodovar et al., 1998). This geological source is readily available for pyrite oxidation. The water quality varies in the rivers flowing through the area and is subject to seasonal variations in the rate of rainfall (Olias et al., 2004).

The study mine site is located in the low altitude, inner mountain chain near the Atlantic coast (Figure 1.1). The regional climate follows a Mediterranean climate trend 
tempered by the influence of the Atlantic Ocean (Font Tullot, 1983), with mild winter and warm and dry summer. The Mediterranean climate is characterized by a wet season from October to May, and a dry season from late May to the summer. The insulation rate is extremely high throughout the year. A low precipitation rate defines a semi-arid climate with permanently low water table. The typical vegetation is a deciduous or evergreen wood with abundant Quercus suber, and strata of shrubs and grass. Modern forest management involves large areas planted with Eucaliptus trees, and plantations of orange trees (Citrus rutaceae) in formerly operated mine sites.

Industrial operation on most metallic mine sites in the Iberian Pyrite Belt has now ceased. Most mine facilities are abandoned and are under the control of the environmental authorities. They are numerous and the wide regional exposure of abandoned mine waste makes the Iberian Pyrite Belt an ideal validation site for testing environmental monitoring methods.
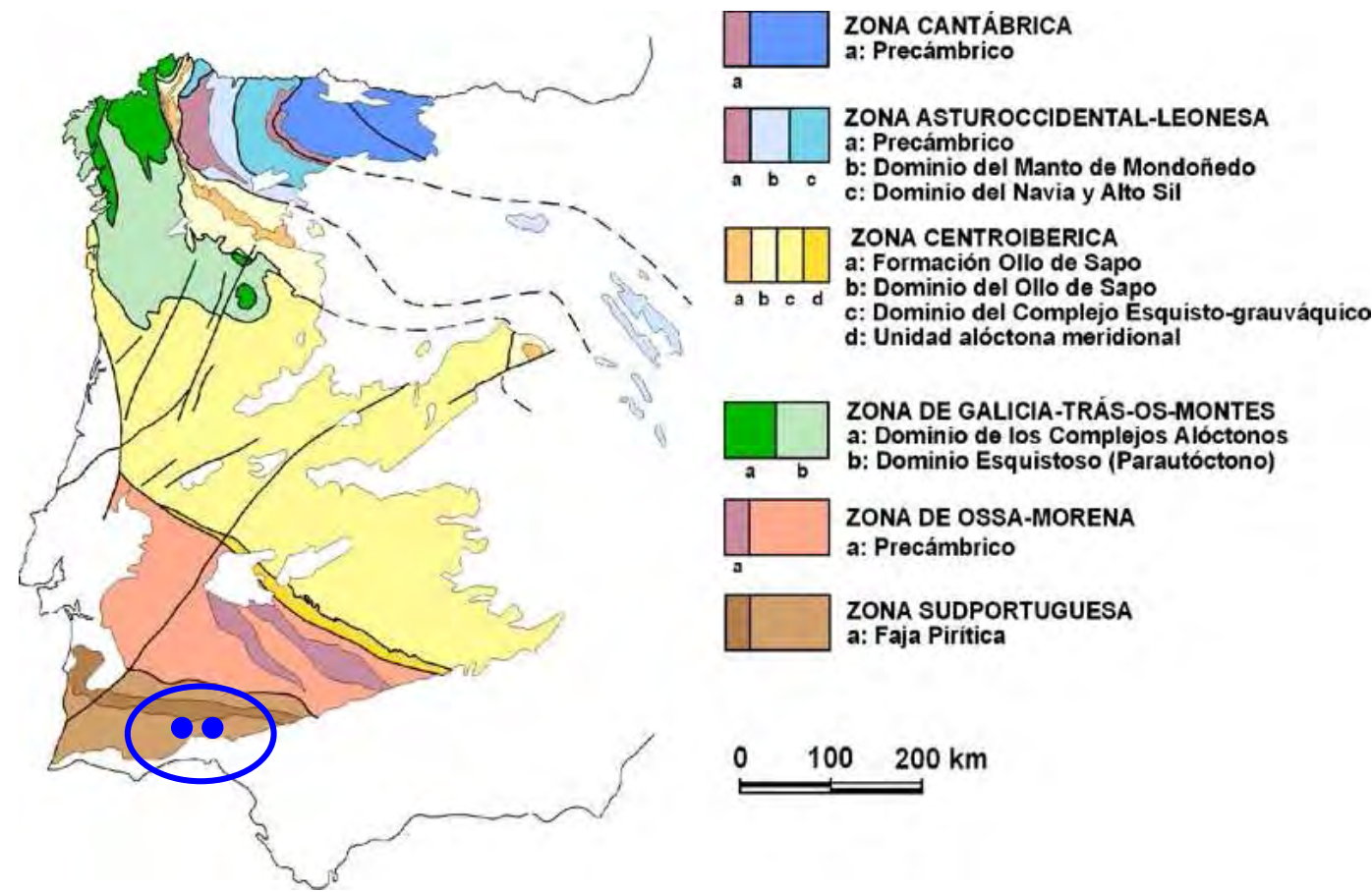

a: Precámbrico

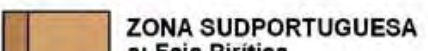

a: Faja Piritica

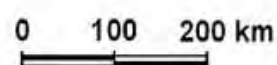

Figure 1.1. Location of the study area in the Iberian Hesperian Massif (Spain and Portugal) (blue circle). In: Vera et al., 2004. Blue dots are the locations of the mine sites and the Odiel River.

Figura 1.1. Situación del área de estudio en el Macizo Hespérico Ibérico (España y Portugal) (círculo azul). En: Vera et al., 2004. Los puntos azules son localidades de las minas estudiadas, y el río Odiel. 


\subsection{THE TEST SITES}

Two environments are considered for monitoring: the mine works in Sotiel, which spread along the Odiel River (Figure 1.2), under recovery from 2006, the mine site of Las Herrerías, abandoned since the late eighties, and the flow path of the Odiel River from the head to the entrance to the estuary.

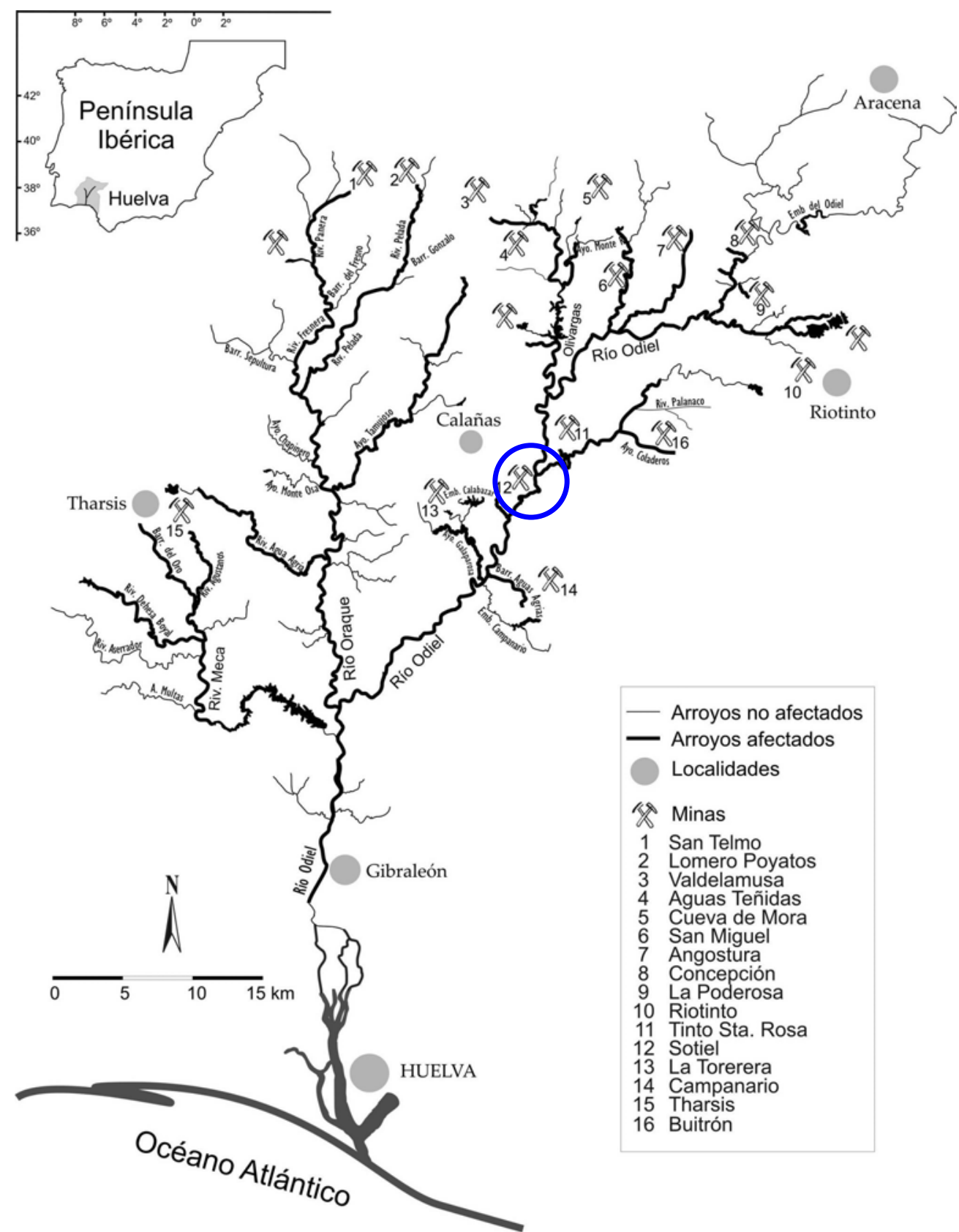

Figure 1.2. River basin of the Odiel River, with enhanced contaminated parts (in Sarmiento et al., 2009). In blue, the mine site of Sotiel.

Figura 1.2. Cuenca de drenaje del río Odiel, con zonas contaminadas en trazo grueso (Sarmiento et al., 2009). En azul, la mina de Sotiel. 


\subsubsection{THE MINE SITE OF SOTIEL}

Tartesians and Phoenicians already worked the mines on the Iberian Pyrite Belt before Roman times. Mining continued during the Middle Ages using traditional mining methods, up to the intensive operation during the Industrial Revolution in the $19^{\text {th }}$ Century. In the recent past, massive sulphide deposits hosted on basalts were mined until the 1980's, when mining stopped.

From 1991 to 2001, the ore processing plant of the Sotiel mine site toasted industrial sulphide waste to produce sulphuric acid which was delivered to the nearby coastal industrial facilities. The mine site is nowadays being rehabilitated by the regional government.
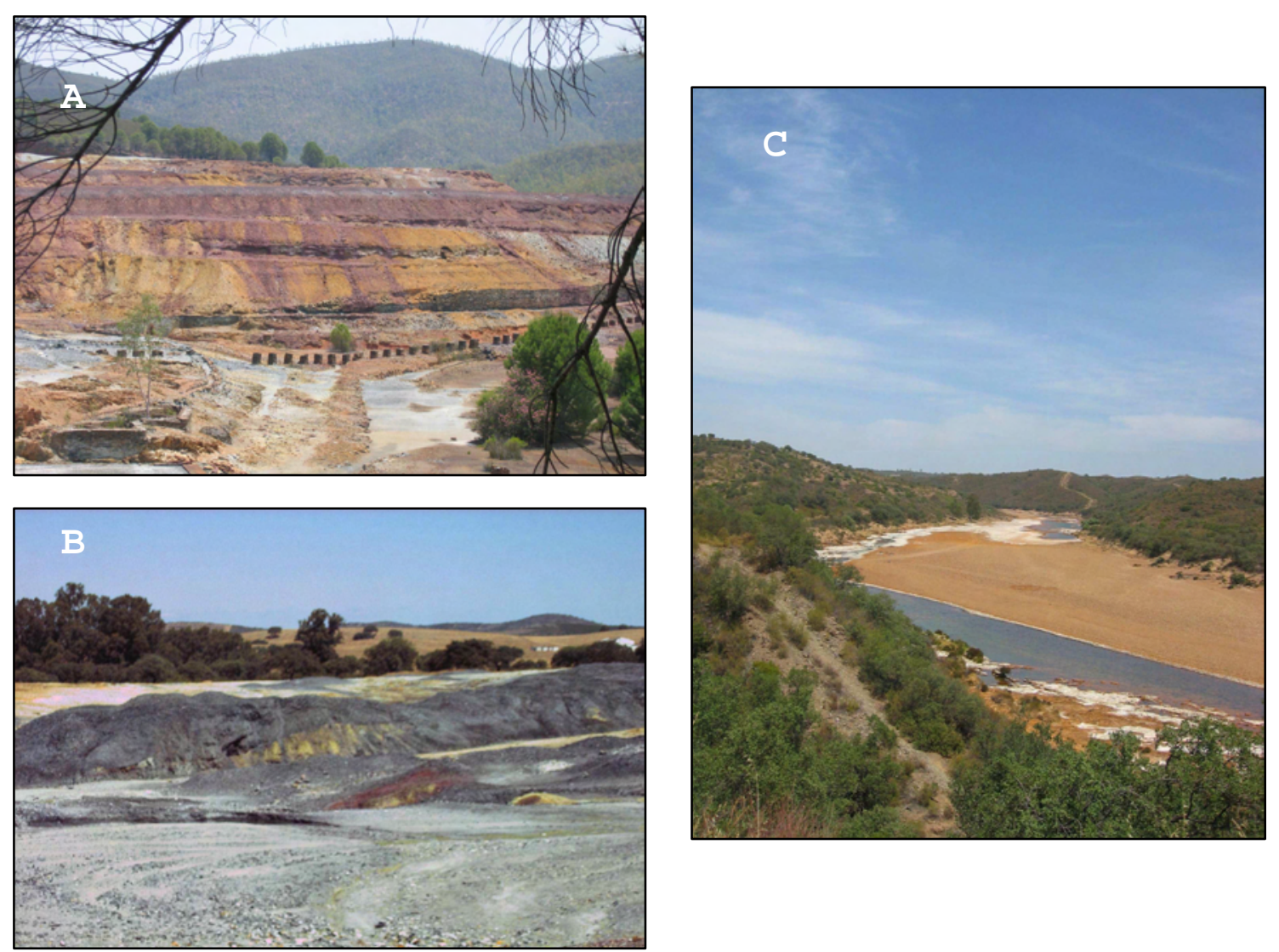

Figure 1.3. The test sites. A: Mine site of Sotiel. B: Dumps at the mine site of Las Herrerías. C: Braided riverbars in the Odiel River.

Figura 1.3. Las zonas de estudio. A: Mina de Sotiel. B: Escombreras en la mina de Las Herrerías. C: Barras fluviales trenzadas en el río Odiel.

The operating underground mine works are visible along the river Odiel (Figure 1.3A). Pyrite mud is stored in a dam draining to the river Odiel, upstream from the mine works. Secondary minerals precipitated from acid water cover the banks of the river. 


\subsubsection{THE MINE SITE OF LAS HERRERIAS}

The mine site of Las Herrerías (Pyrite Belt, SW Spain), which mined complex iron sulphide, stopped operating during the eighties. Ore extraction took place through two open pits, now flooded with water (Figure 1.3 B). Dumps, ponds and water reservoirs have not received industrial supplies for more than twenty years. The two main open pits extracted different metals: the so-called "pyrite" open pit mined mainly iron sulphide, and the "copper" open pit mined sulphide with abundant copper. The water from the copper open pit drains to a series of three lixiviating ponds, sequentially washing the metal contents. The remaining mill tailing ponds are now dry.

Three water dams, storing freshwater which supplied water for the mine operations, are located to the east of the mine site. Today, two of them supply water to the nearby towns and the third collects the towns' sewage.

\subsubsection{THE RIVER ODIEL}

The Odiel River (Huelva, southwest Spain) runs through the Iberian Pyrite Belt, a wide geological unit within the Hesperian Massif containing massive sulfide deposits that have been exploited for at least 5000 years (Figure 1.1). Pyrite is abundant both on mine waste and rock outcrops, and acid mine drainage (AMD) is present in most drainages throughout the region (Figure 1.2) (Sarmiento et al., 2009). The Pyrite Belt consists of a thick sequence of vulcanoclastic sediments with interstratified quartzite, sandstones and slates, at the foot of the northern Sierra de Aracena, characterized by numerous igneous outcrops. The landscape is a smooth ridge-valley alternation, with an average elevation difference of $100 \mathrm{~m}$.

The Odiel River flows across various strata in a low sinuosity channel controlled by floodplain lithology. The general flow path is linear with minor deviations when crossing more competent rock layers, where water retention and diversion walls from historic watermills are abundant. Depositional bars develop along the length of the river, increasing in size downstream. The Odiel River can be considered a bedload transport stream with low sinuosity but considerable lateral mobility. The channels shift into different paths, resulting in braided side channels separated by sand and gravel bars (Figure 1.3B). In the furthest downstream reaches, immediately before the estuarine marshes, the banks tend to be steeper and the braided bars demonstrate a systematic grain size sediment pattern. 
Typically, bars in the lower river reaches display a top of coarse, heterogeneous rocks less than $10 \mathrm{~cm}$ in diameter. As the river approaches the estuary at the Atlantic Ocean, hydrodynamic changes occur that result in a thinning of the size of bar sediments, dominated by sands with reduced pebble tops. As the river channels widen the bars become more stable with vegetation growth, and larger areas of mud bars develop.

In the lower reaches of the river, tides move salt water in and out of the estuarine segments. The marine water is characterized by a basic $\mathrm{pH}$ that influences AMD and resulting mineral growth. The present study investigated how hyperspectral imagery can detect the tidal influence on both sediments and river water before entering the estuarine marshes.

\subsection{DATASET AND METHOD}

This work aims to evaluate critical parameters on the contamination from sulphide mine waste through maps produced from hyperspectral data which can be a regular monitoring tool. To interpret the imagery, repeated on time, local field and laboratory spectra are collected. A reference spectral library developed in the laboratory (Crowley et al., 2003) is necessary to interpret the mineralogical meaning of the spectra in a geological context.

\subsubsection{HYPERSPECTRAL IMAGERY}

Hymap airborne data, were acquired over the Sotiel mine site and the Odiel river path on the $17^{\text {th }}$ July 2005, the $4^{\text {th }}$ August 2008 and the $13^{\text {th }}$ August 2009. Hymap is an airborne hyperspectral sensor with 126 wavebands from 436 to $2485 \mathrm{~nm}$ with a spectral resolution of $10-20 \mathrm{~nm}$. Its spatial resolution is $5 \mathrm{~m}$.

Hyperion spacecraft data were acquired over the mine site of Herrerías (western Pyrite Belt) on the $10^{\text {th }}$ September 2006 and the $24^{\text {th }}$ August 2007.

\subsubsection{FIELD SPECTRA}

Field measurements were taken with an ASD FieldSpec 3 Spectrometer (ASD Inc., Boulder, Co, USA) during 2005, 2008 and 2009 campaigns for sensor calibration and thematic purposes. This device measures ground reflectance spectra covering the wavelength range from $350 \mathrm{~nm}$ to $2500 \mathrm{~nm}$, with the following coverage and resolutions summarized in Table 3 (ASD, 2006). 

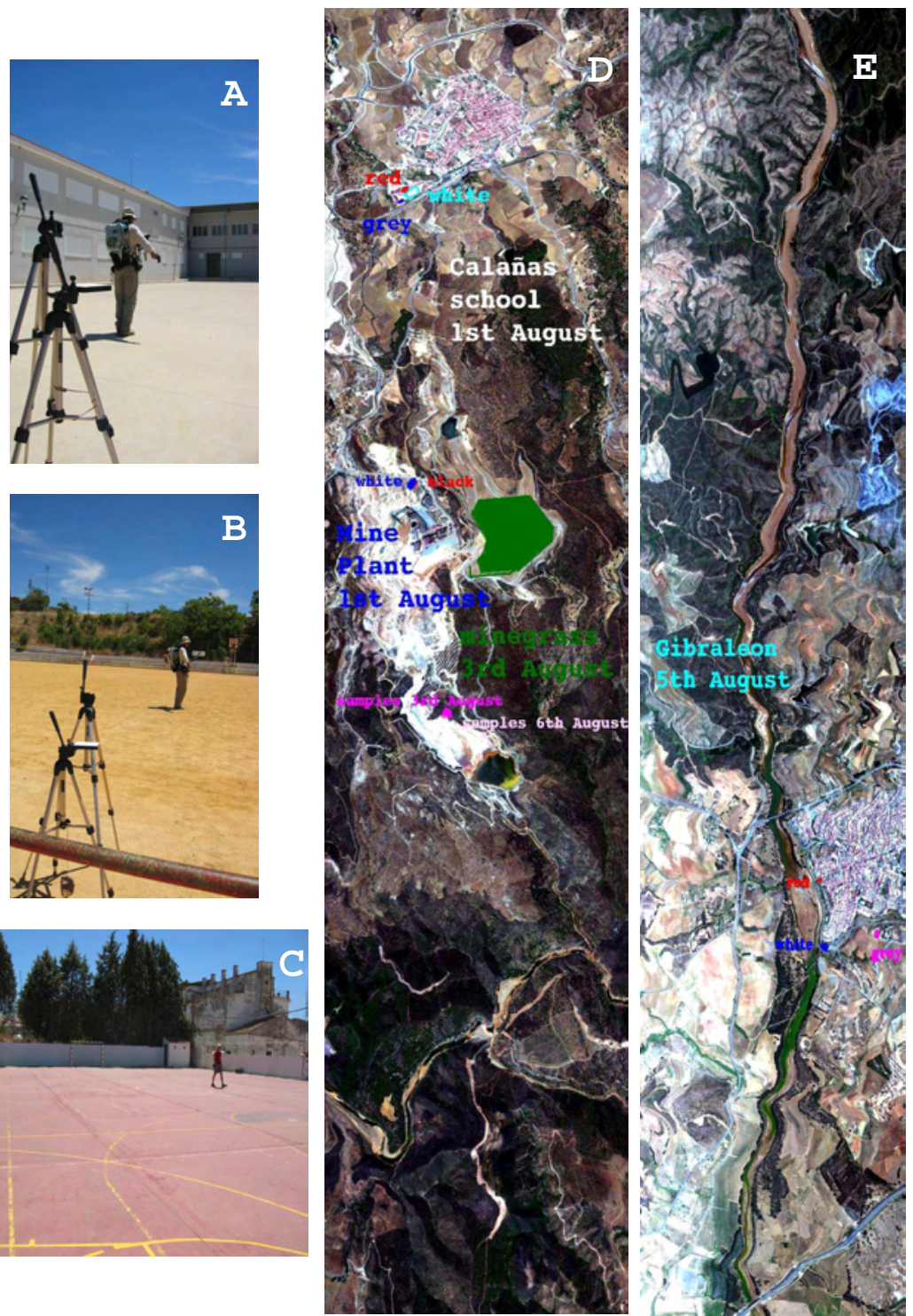

Figure 1.4. Calibration targets. A, B and C: Large spectrally homogeneous urban sites used as calibration targets. D and E: Location of the calibration targets in the towns of Calañas and Gibraleón.

Figura 1.4. Blancos de calibrado. A, B y C: superficies urbanas espectralmente homogéneas suficientemente grandes como para servir de blancos de calibrado de líneas de vuelo. D y E: Situación de los blancos de calibrado en los pueblos de Calañas y Gibraleón.

Ground spectral measurements taken during the flight as reference targets to allow an additional vicarious calibration. Image reflectance values can be validated comparing them with field spectroscopic measurements over large, bright and spectrally homogeneous areas. Around 100 spectral measurements were taken per calibration target, using bare fibre, that gives a field of view (FOV) of about $60 \mathrm{~cm}$ diameter at a height of $1 \mathrm{~m}$ above ground (Figure 1.4). 


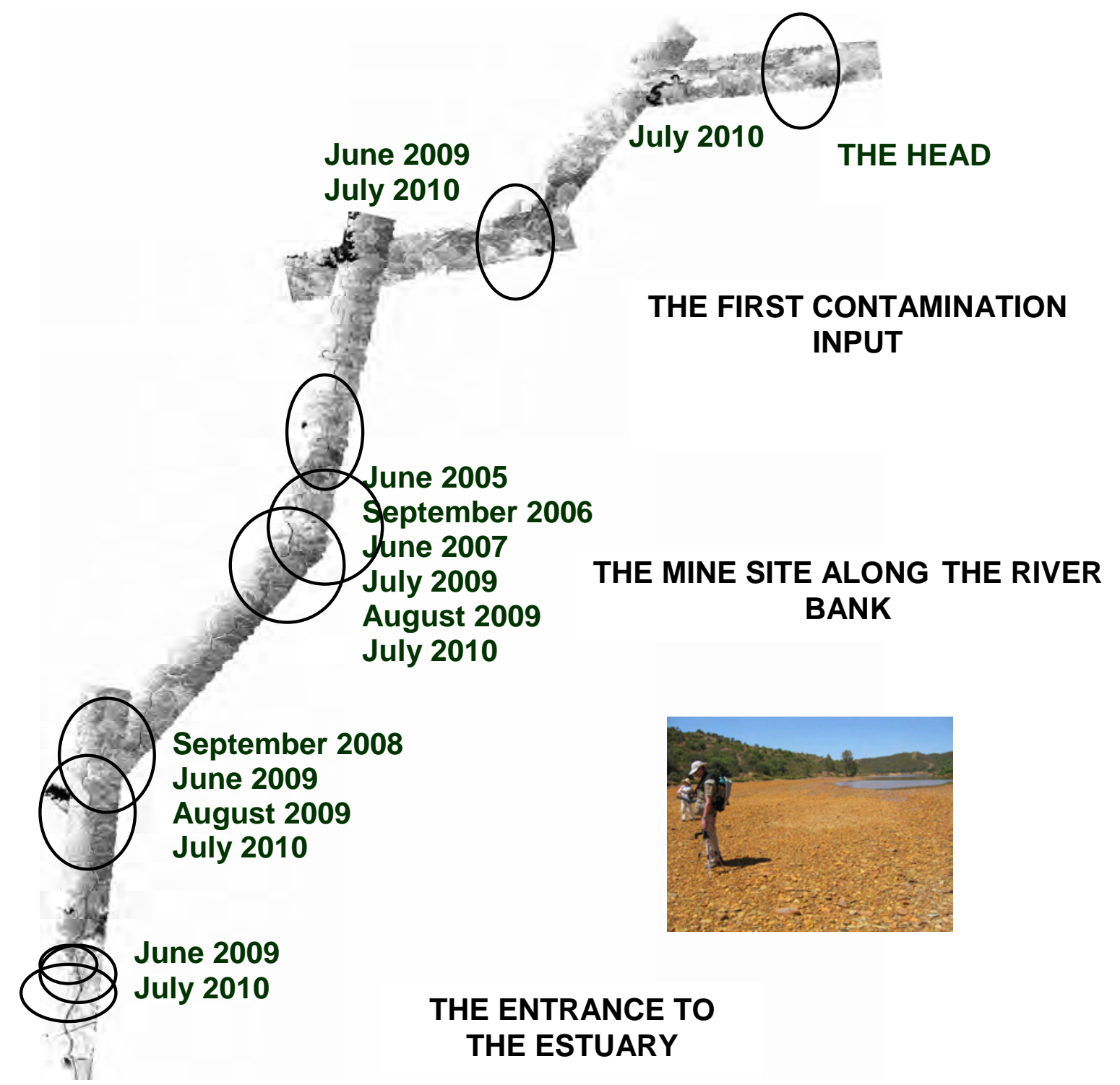

Figure 1.5. Mosaic with the six Hymap flight lines covering the flow path of the Odiel River in 2008, with test sites and locations and dates of field spectra.

Figura 1.5. Mosaico con las seis líneas de vuelo que recorren el curso del río Odiel en 2008, con las zonas de estudio y la situación y fechas en las que se tomaron espectros de campo.

Additionally, field spectra were collected for geological interpretation (Figure 1.5).

Fieldwork was conducted in the summers of 2005, 2006, 2007, 2008, 2009 and 2010. Around 1700 geologically documented spectra were measured both in the field and in the laboratory from field samples collected between 2005 and 2010. Laboratory monitoring of the mine dumps and river sediments was conducted in 2007 on 30 samples, using additional 80 geologically documented field spectra (Riaza et al., 2011b). The entire flow path of the Odiel River was analysed, including 200 field spectra, which were measured in 2005 using an ASD spectrometer, and 600 
geologically documented field spectral measurements, which were collected in September 2008, from June 2009 to August 2009, June 2010 and July 2011 with an ASD FieldSpec 3 Spectrometer (for thematic purposes) (Riaza and Carrère, 2010b). 178 selected samples from river sediments were measured in the dark room from 2008 to 2011. Field spectra interpretation on mine sites begun with a field campaign of measurement, which were collected on the $17^{\text {th }}$ of June 2005, in parallel with a Hymap flight over the same region (Riaza et al., 2007; Riaza and Müller, 2010c), which covered a restricted part of the middle course of the River Odiel, where the old SotielAlmagrera mine site is located. The interpretation of laboratory spectra on samples collected in the field in 2006 (Riaza et al., 2010a) and 2007 (Buzzi et al., 2010) lead the interpretation of both field and laboratory spectra collected during the summer of 2009, 2010 and 2011. A total of 247 field sites were measured on mine sites from 2008 to 2011, including rock and water measurements, and 45 additional selected samples from the mine sites were measured in the dark room within the same span of time.

The optic fibre was fed into the pistol grip, which was installed on a tripod at $30 \mathrm{~cm}$ above the ground under direct solar illumination, to ensure stability and uniform measurement conditions. When the surface to be measured was muddy and unstable and did not allow the use of the tripod, manual operation of the pistol grip was necessary. A panel was used as a white reference at the beginning of every session. The reference panel was made of polytetraflouroethylene (PTFE) and cintered halon. It was nearly $100 \%$ reflective within the wavelength range of $350 \mathrm{~nm}$ to $2500 \mathrm{~nm}$. The white reference panel scatters light uniformly in all directions within that wavelength range.

Ten spectra per measurement were programmed for field and dark room spectra to ensure statistical reliability. To avoid local influence of shadow or grain size, the tripod was moved to three separate points in each location, and measurements were taken several centimeters apart in each location. All spectra per location were averaged for later analysis, if no discrepancies in individual measurements were found. The same system was used in the dark room. If the surface to be measured in the dark room was heterogeneous, measurements were taken over several points to estimate possible diverse spectral responses related to mineralogy or texture.

Field spectra exhibit systematic noise on water absorption bands within 1.361-1.409 $\mu \mathrm{m}$ and 1.809-1.965 $\mu \mathrm{m}$ wavelength ranges. Field spectra were resampled to the wavelengths of the spectral archive reference library, with a $4 \mathrm{~nm}$ spectral resolution. 
Data corresponding to field noisy wavelength ranges were eliminated from the archive spectral library before any spectral analysis.

\subsubsection{LABORATORY SPECTRA}

Laboratory spectral measurements were performed with the same ASD device that the field measurements, using an artificial light source. The instrument was set to take 5 measurements per sample.

Samples of mud crusts, coated boulders, and sand, were collected on river sediments, pyrite mud and mine dumps, and sealed in plastic bags or plastic boxes, to be used for spectral measurements in the dark room. Care was taken to keep the surface of pebbles, boulders or crusts in their original upward positions, since the mineralogy on the downside face could be different. The optic fibre fed into the pistol grip was used on a tripod at the same height over the sample to be measured as in the field. In the dark room, a space built to avoid incoming light, a lamp specifically fitting the spectrometer illumination requirements was used at maximum illumination capacity. The lamp illuminated the sample with a $45^{\circ}$ angle. Both lamp and tripod were in fixed positions on an optical table to ensure constant conditions. Soil colour records were estimated using a Munsell Soil Colour Chart (Munsell, 1990) under a constant illumination source.

\subsubsection{ADDITIONAL DATA}

Rock, loose material and water samples have been collected on mine dumps and water bodies.

\subsubsection{Mine standing water bodies}

Rocks and soils are mineralogically analysed, and selected samples undergo powder Xray diffraction analysis focused on iron sulphate and oxides, and salts introduced by mine industrial operation, such as phosphate, chloride and fluoride.

Several physicochemical parameters were measured in the laboratory on water samples.

Specific conductance at $20{ }^{\circ} \mathrm{C}$ and $\mathrm{pH}$ were measured using a Crison Micro CM2201 and a $781 \mathrm{pH} /$ Ion Meter (Metrohm). Oxidability (or permanganate index) was determined using potassium permanganate $\left(\mathrm{K} \mathrm{MnO}_{4}\right)$ in acid and ebullition conditions. 
Sodium and potassium concentrations were measured using an Atomic Absorption Spectrometer (Varian SpectrAA 220 Fast Sequential) by atomic emission.

Ammonium, calcium, magnesium and bicarbonate concentrations were determined by a Continuous Flow AutoAnalyzer (CFA) (Futura Alliance Instruments).

Anions (Fluoride, bromated, chloride, nitrite, bromide, nitrate, phosphate and sulphate) were determined by High Performance Ion Chromatography (HPIC) using a Methrom 881Compact IC Pro System fitted with an MetrosepA Supp7-250 column, flow $0.7 \mathrm{ml}$ and $3.6 \mathrm{mM}$ sodium carbonate as eluent solution.

Concentrations of dissolved metals were simultaneously determined by ICP/Mass, according to EPA 200.8 regulation. The determination limits were 0.2-2 $\mu \mathrm{g} / \mathrm{l}$.

Boron was determined by Inductively Coupled Plasma Atomic Emission Spectrometry (ICP-AES) (Varian Vista MPX) with axial disposition.

Volatile organic compounds (0.05-100 $\mu \mathrm{g} / \mathrm{l})$, pesticides and polycyclic aromatic hydrocarbons compounds (5-100 ng/l) were determined by Gas Chromatography/Mass in tandem (Varian 4000) using the EPA 601/602 Calibration Mix standard for volatiles and the PAH-MIX 20 and Pesticide Mix 102 standards for hydrocarbons and pesticide.

1.7.4.2. River flowing water

Water samples were collected along the river Odiel on the same day of the overflight, on the $1^{\text {st }}$ of August 2008 and the $13^{\text {th }}$ of August 2009, along the whole length of the river course. Physicochemical parameters such as temperature, $\mathrm{pH}$, specific conductance, electronic conductivity, dissolved oxygen and redox potential were measured in the field. Sulphate anions $\mathrm{SO}_{4}{ }^{2-}$ and concentrations of dissolved $\mathrm{Al}, \mathrm{As}, \mathrm{Ca}, \mathrm{Cd}, \mathrm{Co}, \mathrm{Cr}, \mathrm{Cu}$, $\mathrm{Fe}, \mathrm{K}, \mathrm{Mg}, \mathrm{Mn}, \mathrm{Na}, \mathrm{Ni}, \mathrm{Pb}, \mathrm{Sb}, \mathrm{Se}, \mathrm{Si}, \mathrm{Sn}$ and $\mathrm{Zn}$ were determined by Inductively Coupled Plasma Atomic Emission Spectrometry.

\subsection{CONCLUSIONS}

The geochemical processes involving weathering of sulphide mine waste and subsequent spreading by runoff are described. The climatic control of such processes and the critical influence of the development of mineralogical phases related to water quality on drainages is also introduced. 
The geological and geomorphological setting of the region framing the test site, including historical records, emphasize the need of adequate monitoring tools.

The basics and methods used by imaging spectroscopy as a monitoring tool of mine waste environments are displayed in detail.

Additional information from conventional chemical and geological techniques is also referred as a necessary input for the establishment of a monitoring method using imaging spectroscopy. 


\section{CHAPTER 2}

\section{MAPPING THROUGH IMAGE PROCESSING}

\subsection{INTRODUCTION}

Hyperspectral remote sensing deals with airborne and spaceborne imaging spectrometers with a spectral resolution simmilar to field or laboratory instruments. A large number of channels in two dimensions requires image processing procedures able to manage high dimensionality on data. Algorithms particularly designed to extract spectral features from a large number of data arranged on layers were developed and gathered in widely available software (RSI, 2000). The new analytical techniques permit a new understanding of the geological expression on the surface of the earth which is not accessible through spectral broad and sensors.

Sensors record data including a number of effects, such as noise from the instrument itself, distortions produced during the navigation or by the influence of the atmosphere. Radiance data must be converted to reflectance through atmospheric corrections. The removal of effects previous to the thematic interpretation is known as preprocessing.

This chapter aims to describe the series of algorithms used to produce maps on mine dumps and tailings, mine water ponds, and river sediments and water, which enable a qualitative and quantitative estimation of land parameters related to the contamination produced by mine waste of sulphide ore deposits.

\subsection{SENSORS}

Two hyperspectral instruments are used in this work. HyMAP is an airborne spectrometer based in Australia and privately operated, whereas Hyperion is a spacecraft sensor operated by NASA (National Air and Space Administration, USA) under the scope of the Earth Observation EO-1 Program.

\subsubsection{HYMAP AIRBORNE DATA}

The Hyperspectral Mapper (HyMap) is an airborne imaging spectrometer collecting energy in the reflected solar region of the electromagnetic spectrum (0.4 to $2.5 \mu \mathrm{m}$ ). It 
uses four detectors in the visible, near infrared and shortwave infrared wavelength ranges (table 1) in 126 channels (Cocks et al., 1998). The spectral coverage is nearly continuous through these regions. The spatial resolution depends mainly on flight height, from 4 to $10 \mathrm{~m}$.

\begin{tabular}{|c|c|c|c|}
\hline \multicolumn{4}{|c|}{ Operational parameters } \\
\hline Platform & \multirow{3}{*}{\multicolumn{3}{|c|}{$\begin{array}{l}\text { Light, two-engine aircraft. } \\
2000-5000 \text { m.a.s.l. } \\
110-180 \text { knots }(200-370 \mathrm{~km} / \mathrm{h})\end{array}$}} \\
\hline Altitudes & & & \\
\hline Ground speed & & & \\
\hline \multicolumn{4}{|c|}{ Spatial configuration } \\
\hline \multirow[t]{2}{*}{ IFOV } & \multicolumn{3}{|c|}{$2.5 \mathrm{mrad}$ along track } \\
\hline & \multicolumn{3}{|c|}{$2.0 \mathrm{mrad}$ across track } \\
\hline FOV & \multicolumn{3}{|c|}{$61.3^{\circ}(512$ pixels $)$} \\
\hline Swath & \multicolumn{3}{|c|}{$2.3 \mathrm{~km}$ at $5 \mathrm{~m}$ IFOV (along track) } \\
\hline & \multicolumn{3}{|c|}{$4.6 \mathrm{~km}$ at $10 \mathrm{~m}$ IFOV (along track) } \\
\hline \multicolumn{4}{|c|}{ Spectral configuration } \\
\hline & Spectral range & $\begin{array}{l}\text { Bandwith across } \\
\text { module }\end{array}$ & $\begin{array}{l}\text { Average spectral } \\
\text { sampling interval }\end{array}$ \\
\hline VIS & $0.45-0.89 \mu \mathrm{m}$ & $15-16 \mathrm{~nm}$ & $15 \mathrm{~nm}$ \\
\hline NIR & $0.89-1.35 \mu \mathrm{m}$ & $15-16 \mathrm{~nm}$ & $15 \mathrm{~nm}$ \\
\hline SWIR 1 & $1.40-1.80 \mu \mathrm{m}$ & $15-16 \mathrm{~nm}$ & $13 \mathrm{~nm}$ \\
\hline SWIR 2 & $1.95-2.48 \mu \mathrm{m}$ & $18-20 \mathrm{~nm}$ & $17 \mathrm{~nm}$ \\
\hline
\end{tabular}

Table 2.1. HyMAP technical specifications (Cocks et al., 1998).

Tabla 2.1. Características técnicas del sensor Hymap (Cocks et al., 1998).

Hymap is a stable instrument providing spectrally reliable data after preprocessing, and favours the geological interpretation of the imagery through digital image processing based on reference spectral libraries.

\subsubsection{HYPERION}

Hyperion is an imaging spectrometer including two detectors, and provides mapping through 220 channels between 0.4 and $2.5 \mu \mathrm{m}$ with a spatial resolution of $30 \mathrm{~m}$ (table 2) (USGS 2004). The VNIR (0.4-1.0 $\mu \mathrm{m})$ overlaps with the SWIR (0.9-2.5 $\mu \mathrm{m})$ from 0.9 to $1.0 \mu \mathrm{m}$, permitting cross-calibration between the two spectrometers. 


\begin{tabular}{|c|c|c|}
\hline \multicolumn{3}{|c|}{ Operational parameters } \\
\hline Platform & \multirow{2}{*}{\multicolumn{2}{|c|}{$\begin{array}{l}\text { EO-1 spacecraft. } \\
705 \mathrm{~km} \text { orbital altitude }\end{array}$}} \\
\hline Altitudes & & \\
\hline \multicolumn{3}{|c|}{ Spatial configuration } \\
\hline IFOV & \multicolumn{2}{|l|}{$42.55 \mathrm{mrad}(30 \mathrm{~m})$} \\
\hline FOV & \multicolumn{2}{|l|}{$0.624 \mathrm{mrad}$} \\
\hline Swath width & \multicolumn{2}{|l|}{$7.5 \mathrm{~km}$} \\
\hline \multicolumn{3}{|c|}{ Spectral configuration } \\
\hline & $\begin{array}{l}\text { Spectral range (220 } \\
\text { bands) }\end{array}$ & $\begin{array}{l}\text { Average spectral } \\
\text { sampling interval }\end{array}$ \\
\hline VIS & $0.40-1.00 \mu \mathrm{m}$ & $10 \mathrm{~nm}$ \\
\hline NIR-SWIR & $0.90-2.50 \mu \mathrm{m}$ & $10 \mathrm{~nm}$ \\
\hline
\end{tabular}

Table 2.2: Hyperion technical specifications (USGS, 2004).

Tabla 2.2. Características técnicas del sensor Hyperion (USGS, 2004).

Hyperion is a noisy sensor. Calibration and preprocessing provide data with disadvantageous interpretation possibilities versus airborne Hymap data. However, panoramic view from a spacecraft and the possibility of a regular scheduling offers complementary information in a contamination monitoring system to likely less available airborne Hymap data.

The preprocessing chain below restricts to the data used on this work.

\subsection{HYMAP DATA. PREPROCESSING.}

The raw Hymap data is first system corrected by HyVista (Cocks et al., 1998). The raw digital numbers are corrected for dark current, and converted to physical units of atsensor radiance (unit: $\mu \mathrm{W} / \mathrm{cm}^{2} \mathrm{sr} \mathrm{nm}$ ) using laboratory radiometric calibration and inflight measurements of on-board calibration sources.

The imagery was geocoded at the German Space Agency (DLR) using software based on a parametric approach determining the viewing geometry for each pixel based on sensor-specific parameters, flight parameters such as sensor position and attitude (i.e. roll, pitch, true heading), and additional terrain information from a digital terrain 
model (DEM), resulting in a typical accuracy of about 2 pixels (Schläpfer and Richter, 2002).

For the atmospheric correction, ATCOR4 was used (Richter and Schläpfer, 2002). This physically-based approach, using the MODTRAN radiative transfer code, corrects for atmospheric effects as well as adjacency scattering, and BRDF compensation in order to derive nadir-normalized ground reflectance. Furthermore, topographic correction for different terrain illumination is applied.

With ground measurements for a reference target taken during the over flight, an additional vicarious calibration is carried out. Based on field spectroscopic measurements (Table 2.3) of large and spectrally homogeneous targets, the image reflectance values are validated against the field measurements and -if necessaryadjusted.

\begin{tabular}{|l|l|l|}
\hline Wavelength & Bandwith & Spectral resolution \\
\hline VNIR $(350-1050 \mathrm{~nm})$ & $1.4 \mathrm{~nm}$ & $3 \mathrm{~nm}$ \\
\hline SWIR 1 $(900-1850 \mathrm{~nm})$ & $2 \mathrm{~nm}$ & $10-12 \mathrm{~nm}$ \\
\hline SWIR 2 $(1700-2500 \mathrm{~nm})$ & $2 \mathrm{~nm}$ & $10-12 \mathrm{~nm}$ \\
\hline
\end{tabular}

Table 2.3. Configuration of the ASD FieldSpec 3 Spectrometer (ASD, 2006).

Tabla 2.3. Configuración del espectrómetro ASD FieldSpec 3 (ASD, 2006).

\subsection{HYPERION DATA. PREPROCESSING.}

Hyperion data were acquired over the mine site of Herrerias (western Pyrite Belt) on the $10^{\text {th }}$ September 2006 and $24^{\text {th }}$ August 2007.

The sensor Hyperion is a satellite hyperspectral spectrometer launched by NASA in 2001. It records a continuous spectral coverage of 220 channels between $0.4 \mu \mathrm{m}$ and $2.5 \mu \mathrm{m}$ (USGS 2004) with a spatial resolution of $30 \mathrm{~m}$. Vertical stripes are visible on data, since dead detectors are not interpolated. Not all channels are calibrated, and there is overlap between detectors, resulting on only 196 unique channels (Shih 2004; Richter and Schläpfer 2002). Also, some detectors are systematically faulty, leaving only 167 useful channels (Richter and Schläpfer 2002; Jupp et al., 2001, 2002).

The Hyperion data recorded on the test site on September 2006 (Riaza et al., 2012b) reported additional noisy channels, resulting only 144 useful channels. The same channels are selected on data from August 2007. The first useful channel is centred at 
$426.82 \mathrm{~nm}$ and the last channel is centred at $2355 \mathrm{~nm}$. Wide wavelength ranges between 884.7-1023.4 nm, 1326-1497 nm and 1790-1971 nm lack data. Oxygen (760 $\mathrm{nm}$, channel 41) and most water vapour absorption wavelengthes (channels 79-81: 930 nm- $960 \mathrm{~nm}$; channels 98-101: $1115 \mathrm{~nm}-1150 \mathrm{~nm}$; channels 121-133: $1350 \mathrm{~nm}-1480 \mathrm{~nm}$ and channels 165-182: $1800 \mathrm{~nm}-1970 \mathrm{~nm}$; >2480 $\mathrm{nm}$ ) are removed from the data. From the water vapour absorption wavelength ranges (Jupp, 2001, 2002), only channels between $1115-1150 \mathrm{~nm}$ remain, even noisy. Additional noise is apparent between 752-803 $\mathrm{nm}$. The SWIR is comparatively noisier compared to VNIR.

The remaining 144 Hyperion channels are atmospherically corrected using ground spectra with the Empirical Line method (RSI, 2000). Ground spectra collected in the field for light and dark targets, as well as on the water bodies of the mine site are used for calibration. The spectra collected on the dark ground target could not be used due to its small size far below the $30 \mathrm{~m}$ Hyperion spatial resolution. Spectra collected on water bodies and vegetation was used successfully to calibrate the 144 selected channels.

The data from 2006 show significant cloud cover near the mine site. The cloud mask produced by the atmospherical correction with the FLAASH method (RSI, 2000; Felde et al., 2003; Goetz et al., 2002; Kruse et al., 2004) shows a wrong estimation of clouds over the light target, even when the area was clear on the day of overpass. This is possibly a major error, which prevents an efficient atmospheric correction on Hyperion 2006 data.

\subsection{HYPERSPECTRAL INTERPRETATIVE IMAGE PROCESSING SEQUENCE}

Once Reflectance data are obtained after the preprocessing chain, the next step is to map target geological features on the surface of the earth. A variety of algorithms is developped to manage hyperspectral high dimensional data (RSI, 2000). The following mention intends to explain the basics for the modules used by the author.

The image processsing beguins typically with a Minimum Noise Fraction Transform. The MNF rotation determines the inherent dimensionality of image data, segregates noise in the data and reduces the computation requirements for subsequent processing (Boardman and Kruse, 1994). It is a transform based on the Principal Components Analysis based on the frequency of data. The data space is divided into two parts: one part is associated to the most frequent data, and a second part is dominated by noisy images. A Hymap image with 126 channels is transformed into an output MNF image 
with 126 channels. The first channels are the coherent data, usually from 3 to 10 channels, which are extracted for further use (Figure 2.1).

The selected MNF channels are the input for a Pixel Purity Index search. The PPI finds the most "spectrally pure" pixels in hyperspectral images. It is computed by repeatedly projecting n-dimensional scatterplots onto a random unit vector (Boardman et al., 1995).

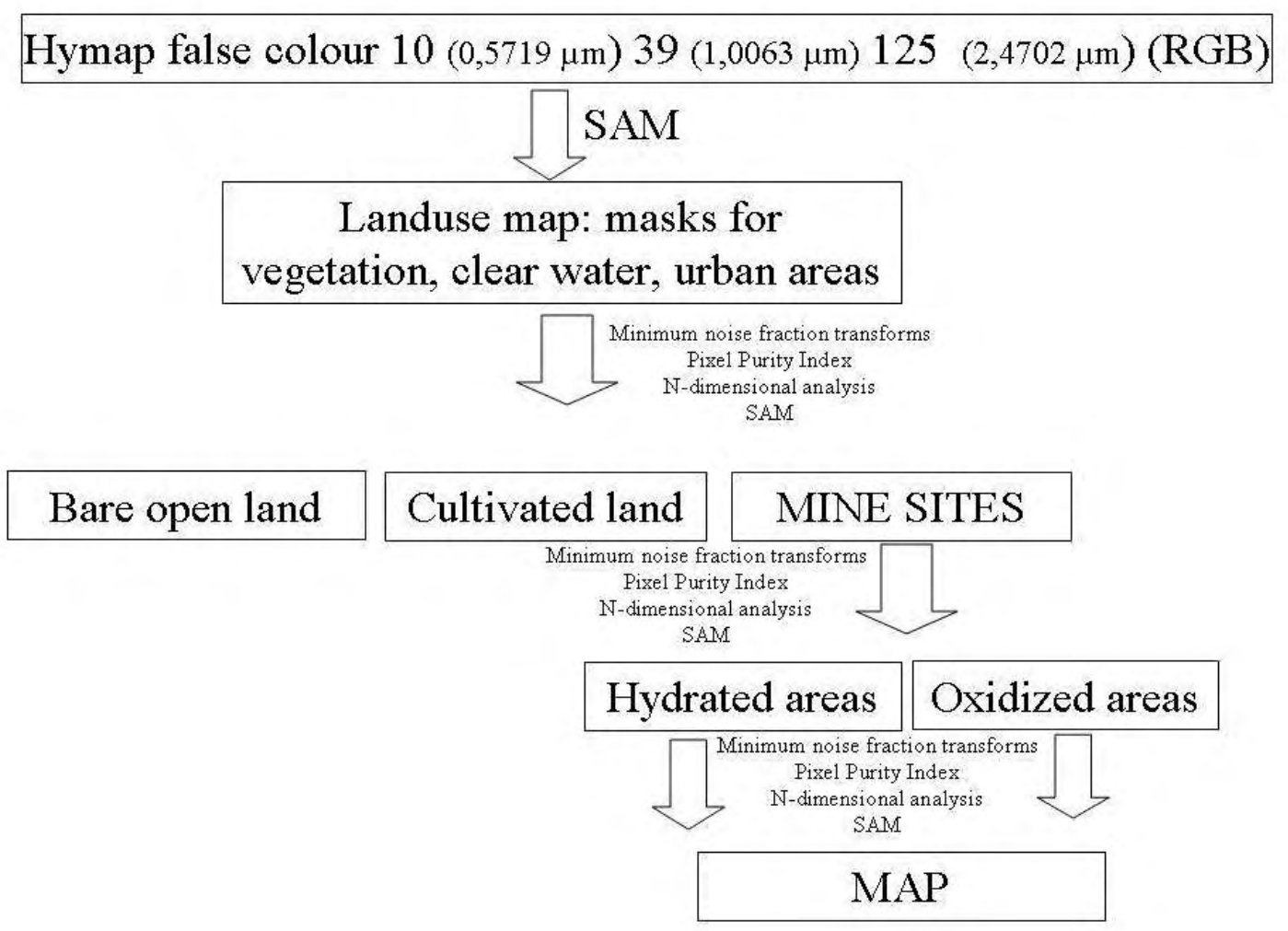

Figure 2.1. Road map showing subsequent image processing steps on Hymap imagery leading to a map of pyrite weathering products on abandoned mine sites.

Figura 2.1. Esquema que resume las etapas de tratamiento de imágenes Hymap hasta el mapa final de productos de meteorización de piritas en minas abandonadas.

The coherent Minimum Noise Fraction Transforms and the areas selected on the Pixel Purity Index as spectrally pure are used by the N-dimensional Visualizer to select the end members in an n-dimensional space (Boardman, 1993). Spectra can be points in an $\mathrm{n}$-dimensional scatterplot, where $\mathrm{n}$ is the number of bands. The pattern of these points in the n-space can be used as to find the number of end members and their spectral signature. In the N-dimensional scatter plot, a number of classes are selected rotating 
the axis of the plot. The classes selected are exported to Regions of Interest, which can be the input for further classification algorithms.

Spectral Angle Mapper is the preferred mapping method using spectra as end-members to map the contamination in the test area (Kruse et al., 1993). Spectra from points on the imagery and the spectral reference end-members are used as vectors. Minimum angles between the two vectors assign each pixel in an n-dimensional image to an endmember, producing a map. If Spectral Angle Mapper uses Reflectance data from a hyyperspectral image, a spectral reference library developed in the laboratory or the field can be used as input to produce a map. The SAM technique, if using calibrated reflectance data, is fairly independent from illumination and albedo.

The chain of algorithms above can be repeated sequentially in a series of subscenes within the image (Hubbard and Crowley, 2005). The dimensionality of the original data is reduced along various image processing steps tailored to the scene, ending on a map of pyrite oxidation products of an abandoned mine site, or coatings precipitated from acid water over river sediments.

\subsection{USING REFERENCE SPECTRAL LIBRARIES}

A number of individual mineral substances precipitated from pyrite acid water were identified using public domain spectral libraries, ranging from melanterite, the firstformed sulphate, to hematite when dehydration and oxidation is completed (Figure 2.2L). Eighteen existing spectra of sulphide oxidation products in public domain spectral libraries (Clark et al., 1993; Crowley et al., 2003) were used as references with the Spectral Analyst (RSI, 2000) to get a comparative score of similarity for spectra from every map unit. The spectral resolution of ASD spectra is higher than the archive spectral libraries. ASD spectra were resampled to the spectral library wavelengths before using the Spectral Analyst (RSI, 2000).

Spectral Angle Mapper, Spectral Feature Fitting and Binary Encoding were taken into account in equal weighting in the final similarity score with a maximum of 1 . The Spectral Angle Mapper determines the spectral similarity between two spectra by calculating the angle between spectra, treating them as vectors in a space with dimensions equal to the number of bands (Kruse et al., 1993). Spectral Feature Fitting compares the fit of image spectra to selected reference spectra using a least-squares technique (Clark et al., 1990). The Binary Encoding algorithm encodes the data and 
end member spectra into zeros and ones, based on whether a band falls below or above the spectrum mean (Goetz et al., 1985).

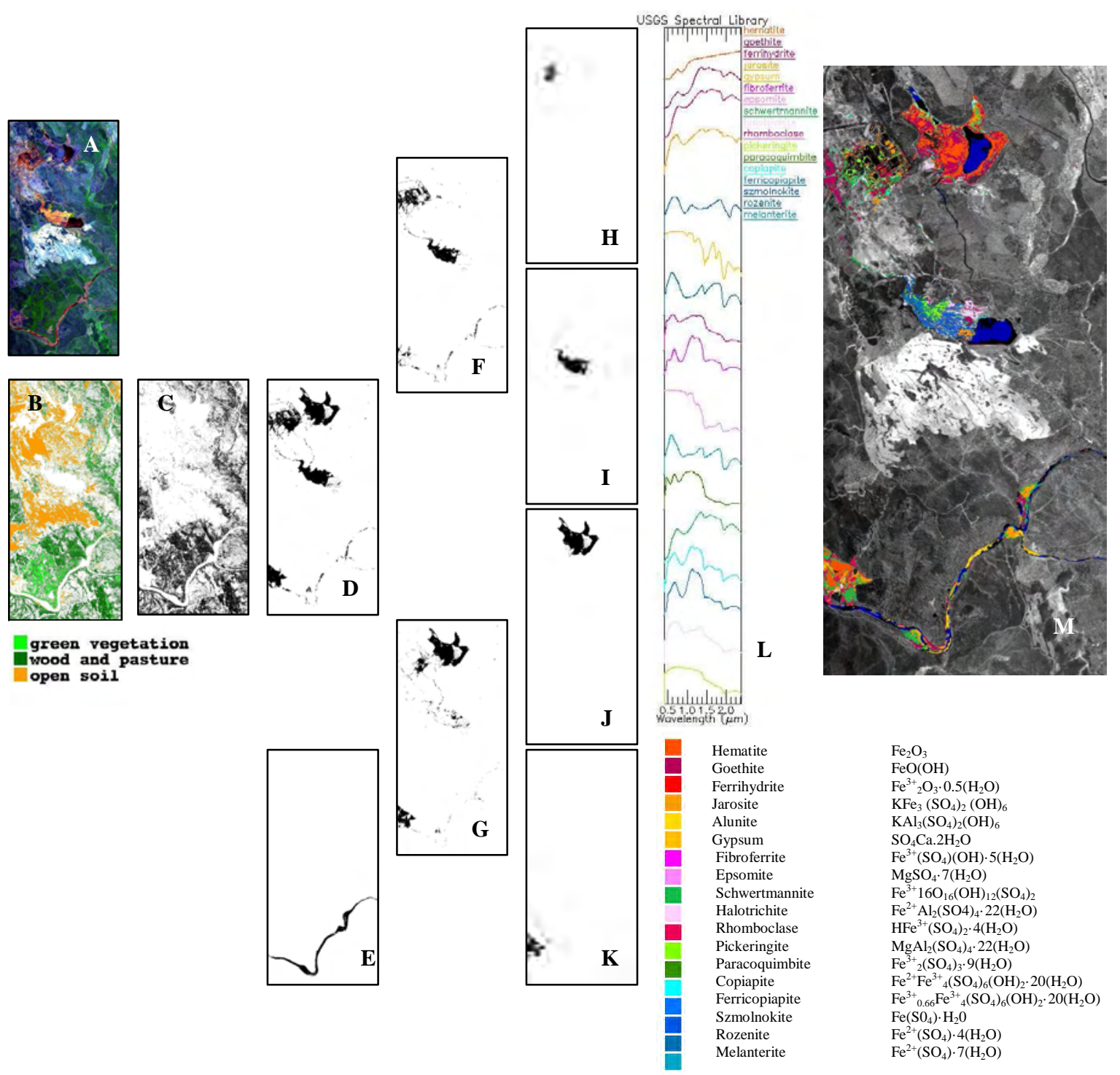

Figure 2.2. Sequential subscenes produced by image processing (from left to right). A: False colour composite with Hymap channels $9(0.5568 \mu \mathrm{m}), 28(0.8460 \mu \mathrm{m})$ and 109 $(2.2074 \mu \mathrm{m})$. B: Land use map estimating vegetation cover and open soil. C: Mask for vegetation. D: Mask for mine waste. E: Mask for the river flow path. F: mask for hydrated tailings. G: Mask for oxidised dumps. H: Mask for hydrated ponds around the ore processing plant. I: Mask for the hydrated mill tailings dam. J: Mask for the oxidised pond of ashes. K. Mask for the main oxidised dump by the river. L: Spectral reference library on pyrite weathering products (Crowley et al., 2003; Clark et al., 2007). Spectra are displaced vertically for clarity. M: Final map of coatings of pyrite weathering products over mine waste and river sediments following the reference spectral library (Crowley et al., 2003).

Figura 2.2. Secuencia de subescenas producidas durante el tratamiento de imágenes (de izquierda a derecha). A: composición en falso color con los canales Hymap 9 $(0.5568 \mu \mathrm{m}), 28(0.8460 \mu \mathrm{m})$ y $109(2.2074 \mu \mathrm{m})$. B: Mapa de uso de suelo que indica 
la superficie cubierta por vegetación y suelo descubierto. C: Máscara para la vegetación. D: Máscara para los residuos mineros. E: Máscara para el cauce del río. F: Máscara para las balsas con barros cubiertos por sulfatos hidratados. G: Máscara para las escombreras de fragmentos de roca con pátinas oxidadas. H: Máscara para las balsas de barros con sulfatos hidratados alrededor de la planta de tratamiento de

menas. I: Máscara para la balsa de lodos. J: Máscara para la balsa de cenizas oxidadas. K: Máscara para la escombrera oxidada mayor a orillas del río. L: Espectroteca de referencia de productos de meteorización de piritas (Crowley et al., 2003; Clark et al., 2007). M: Mapa final de costras de productos de meteorización de

piritas sobre residuos mineros y sedimentos fluviales diagnosticados con la espectroteca de referencia de productos de meteorización de piritas.

The scores per sample from the Spectral Analyst for the three algorithms are displayed in a table for each of the three outcrops considered, daily when measured throughout the summer (Riaza et al., 2011b). The minerals are displayed in the table using a sequence of oxidation and dehydration, to ease identification of trends. The three minerals with the best scores per sample are displayed in a table, and labelled in spectral library graphs. General trends and small changes in mineralogical identification can thereby be traced in detail. The mineralogical identification capability of Spectral Angle Mapper, Spectral Feature Fitting and Binary Encoding is discussed below.

\subsection{IMAGE PROCESSING TO MAP THE CONTAMINATION ON MINE WASTE}

The procedure for feature extraction for thematic purposes used on this work is an interpreter oriented sequential spectral unmixing using standard algorithms, leading to a spatial pattern and spectral identification pixels within the scene displayed as a map. The dimensionality of the data is reduced along various image processing within subscenes extracted at several steps through the chain of image processing, ending on a map of pyrite oxidation products of the abandoned mine site (Figure 2.1) (Riaza and Müller, 2010).

The first step uses a false colour composite of Hymap channels 10 (0.5719 $\mu \mathrm{m}), 39$ $(1.0063 \mu \mathrm{m})$ and $125(2.4702 \mu \mathrm{m})$ to build a spectral library with basic land use endmembers on the scene (Figure 2.2A). Channel 10 focuses to water properties, channel 39 to vegetation and channel 125 to land. Minimum Noise Fractions are used to explore general land use features. Areas mainly covered by vegetation, clear water and urban areas are excluded from the analysis from this step on, after masks are built based on spectral identification of the main land use regions through Spectral Angle Mapper 
(Figure 2.2B and Figure 2.2C). Then, Spectral Angle Mapper produces again a first estimation of the spectral diversity of open land, which is digitally used as a mask on subsequent image processing steps per scene.

The areas mapped as open land during the first step are analysed using Minimum Noise Fraction Transforms, subsequent Pixel Purity Index (Boardman, 1993) and ndimensional analysis. Mine sites and the main areas covered by sulphate salts are commonly identified from bare open and cultivated land at this stage (Figure 2.2D). The data dimensions are reduced further, repeating the procedure to qualify areas within early-formed salts and among the more oxidized or hydrated zones (Figure 2.2G and Figure 2.2F), which are isolated on corresponding masks (Figure 2.2H, Figure 2.2I, Figure 2.2J and Figure 2.2K). A final map is compiled gathering all end members corresponding to pyrite oxidation products on the scene (Figure 2.2M). A spectral library is finally built with such end members, which are then mineralogically identified by comparison to a selection of mineral spectra from archive spectral libraries (Figure 2.2L), previously resampled to match Hymap wavelength ranges.

Spectral Angle Mapper, Spectral Feature Fitting and Binary Encoding were taken into account using equal weights for each of the final similarity scores. The spectrally dominant mineral was assigned to the map units (Figure 2.2M) using the mean spectra of the corresponding region of interest through the image processing procedure, using the spectral library with pyrite oxidation and precipitation products.

Spectral Angle Mapper (Kruse et al., 1993) is used to test scene similarity from the second step, helping to identify end members more representative of sulphate salt coverage according to field experience and comparison of the shape of the corresponding spectra with archive spectral libraries. Therefore, the spectral shape information is also derived from the Hymap data.

Maps produced with the same method on different seasons and years (Figure 2.3) suggest trends of mineralogical changes which can be an expression of climate variability (Riaza and Müller, 2010). 


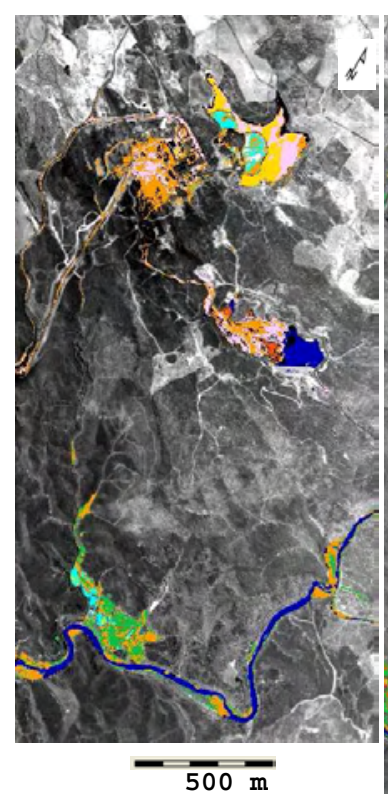

$6^{\text {th }}$ May 1999

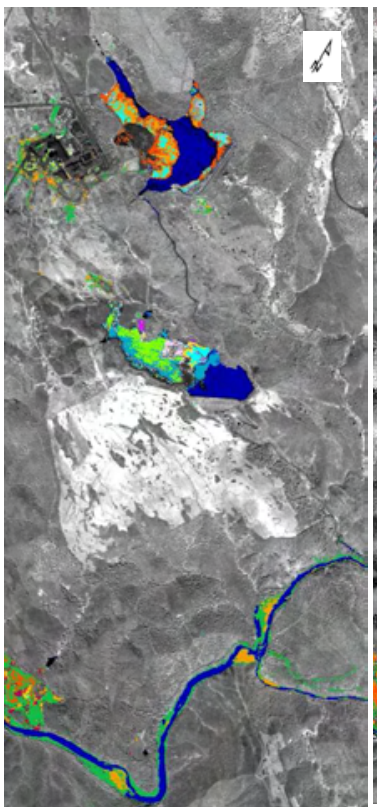

$19^{\text {th }}$ May 2004

$\mathrm{Fe}_{2} \mathrm{O}_{3}$

$\mathrm{FeO}(\mathrm{OH})$

$\mathrm{Fe}^{3+}{ }_{2} \mathrm{O}_{3} \cdot 0.5\left(\mathrm{H}_{2} \mathrm{O}\right)$

$\left(\mathrm{SO}_{4}\right)_{2} \mathrm{KFe}_{3}(\mathrm{OH})_{6}$

$\mathrm{KAl}_{3}\left(\mathrm{SO}_{4}\right)_{2}(\mathrm{OH})_{6}$

$\mathrm{SO}_{4} \mathrm{Ca} .2 \mathrm{H}_{2} \mathrm{O}$

$\mathrm{Fe}^{3+}\left(\mathrm{SO}_{4}\right)(\mathrm{OH}) \cdot 5\left(\mathrm{H}_{2} \mathrm{O}\right)$

$\mathrm{MgSO}_{4} \cdot 7\left(\mathrm{H}_{2} \mathrm{O}\right)$

$\mathrm{Fe}^{3+} 16 \mathrm{O}_{16}(\mathrm{OH})_{12}\left(\mathrm{SO}_{4}\right)_{2}$

$\mathrm{Fe}^{2+} \mathrm{Al}_{2}(\mathrm{SO} 4)_{4} \cdot 22\left(\mathrm{H}_{2} \mathrm{O}\right)$

$\mathrm{HFe}^{3+}\left(\mathrm{SO}_{4}\right)_{2} \cdot 4\left(\mathrm{H}_{2} \mathrm{O}\right)$

$\mathrm{MgAl}_{2}\left(\mathrm{SO}_{4}\right)_{4} \cdot 22\left(\mathrm{H}_{2} \mathrm{O}\right)$

$\mathrm{Fe}^{3+}{ }_{2}\left(\mathrm{SO}_{4}\right)_{3} \cdot 9\left(\mathrm{H}_{2} \mathrm{O}\right)$

$\mathrm{Fe}^{2+} \mathrm{Fe}^{3+}{ }_{4}\left(\mathrm{SO}_{4}\right)_{6}(\mathrm{OH})_{2} \cdot 20\left(\mathrm{H}_{2} \mathrm{O}\right)$

$\mathrm{Fe}^{3+}{ }_{0.6666}{ }_{\mathrm{Fe} 3+}\left(\mathrm{SO}_{4}\right)_{6}(\mathrm{OH})_{2} \cdot 20\left(\mathrm{H}_{2} \mathrm{O}\right.$

$\mathrm{Fe}\left(\mathrm{SO}_{4}\right) \cdot \mathrm{H}_{2} \mathrm{O}$

$\mathrm{Fe}^{2+}\left(\mathrm{SO}_{4}\right) \cdot 4\left(\mathrm{H}_{2} \mathrm{O}\right)$

$\mathrm{Fe}^{2+}\left(\mathrm{SO}_{4}\right) \cdot 7\left(\mathrm{H}_{2} \mathrm{O}\right.$

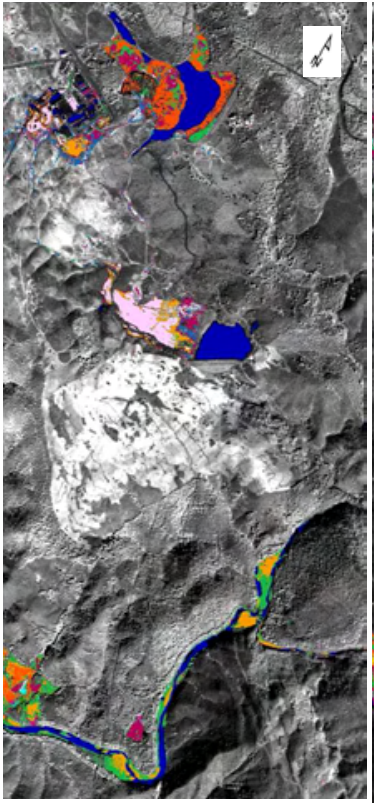

$14^{\text {th }}$ August 2004

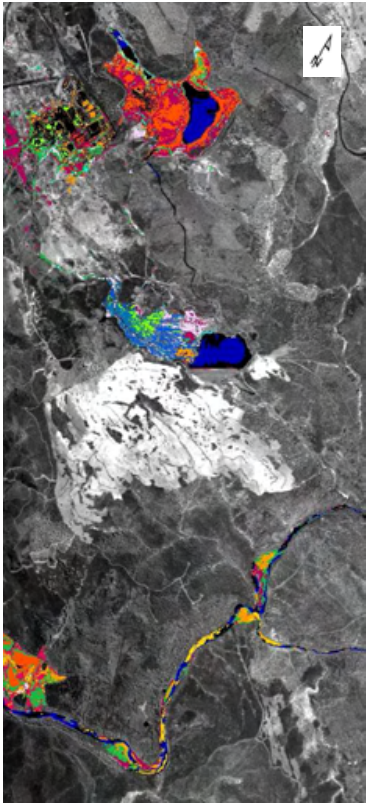

$17^{\text {th }}$ June 2005

Figure 2.3. A, B, C and D: Maps compiled from Hymap data on the minerals product of oxidation and dehydration of sulphide sludge, on the four available flights. Colour coding for minerals mapped with the corresponding chemical formula, arranged on a precipitation and oxidation sequence. Increasing reddish colours suggest intense oxidation. Bluish and greenish colours concentrate on hydrated areas. E: Location of domains within the mine site extracted on open land after excluding bare open land and cultivated land. Colours are displayed for clarity, and have no relationship with the legend of minerals on the left.

Figura 2.3. A, B, Cy D: Mapas elaborados con datos Hymap de productos de oxidación de deshidratación de lodos de sulfuros, en los cuatro vuelos disponibles.

Leyenda de minerales correspondientes con su fórmula química, siguiendo la secuencia de precipitación y oxidación progresiva en el proceso de meteorización. Los colores rojizos indican oxidación predominante. Los colores azulados y verdosos indican predominio de sulfatos hidratados. E: Situación de los entornos cartografiados en el área de la mina, extraído digitalmente a partir de una máscara para el suelo descubierto y zonas cultivadas. Los colores no tienen relación con la leyenda de los mapas anteriores. 


\subsection{IMAGE PROCESSING TO MAP THE CONTAMINATION ON THE RIVER}

The standard sequence of algorithms is Minimum Noise Fraction Transforms (MNFT), Pixel Purity Index and n-dimensional Analysis to extract significant statistical populations (RSI, 2000). The reality of a particular land cover is determined by the spectral response of the regions of interest that correspond to the resulting populations. A land use map was computed with Spectral Angle Mapper (Kruse, 1993) using the appropriate end members (Figure 2.4) (Riaza et al., 2012a).

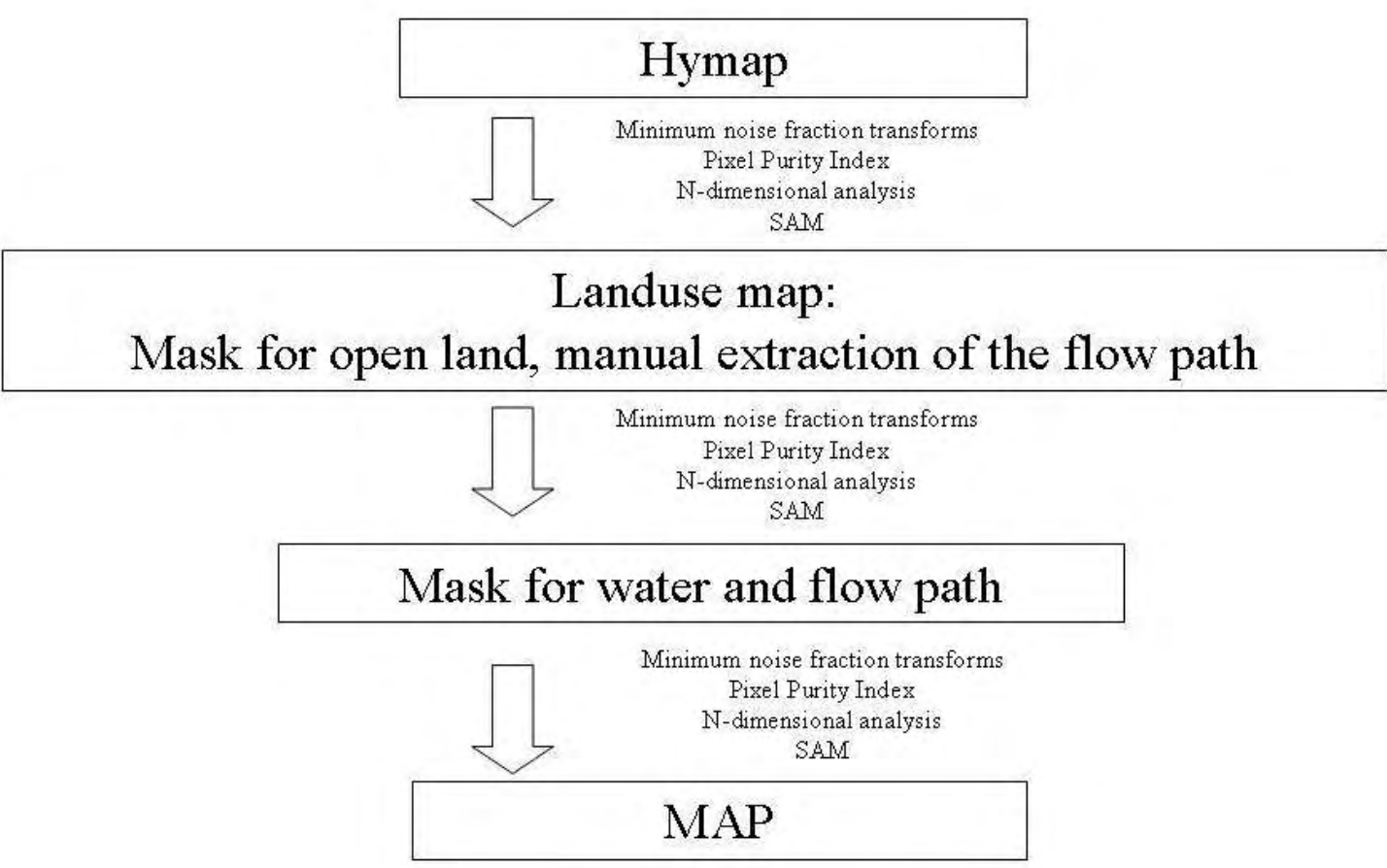

Figure 2.4. Sequence of hyperspectral image processing to produce a map of the river flow path.

Figura 2.4. Secuencia de algoritmos de tratamiento digital de imágenes utilizados para la elaboración del mapa del cauce del río.

A second MNFT was computed on the geometrically- and atmospherically-corrected Hymap image that isolated relatively open land devoid of vegetation. The flow path was precisely drawn, with some areas strongly disturbed by forests or quarries. For those areas, a mask was built and the flow path was manually extracted as a mask to be used during further processing (Figure 2.5B). MNFTs were again computed on the Hymap imagery for the area masked for the flow path. The resulting pattern displayed the sinuous shapes typically associated with river geomorphology. 


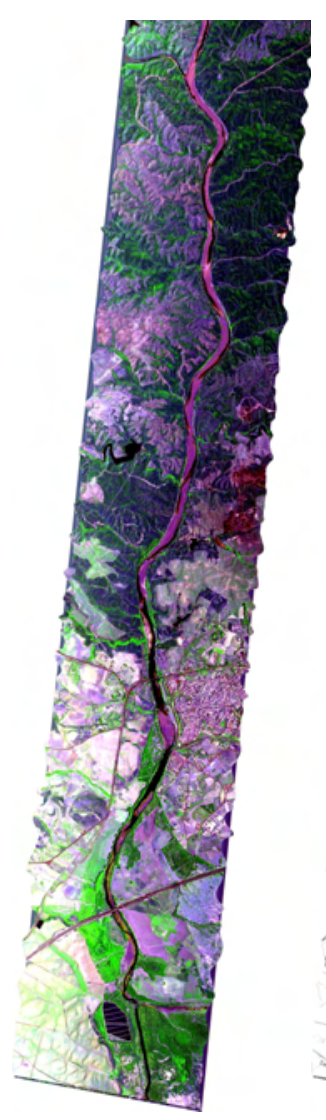

A

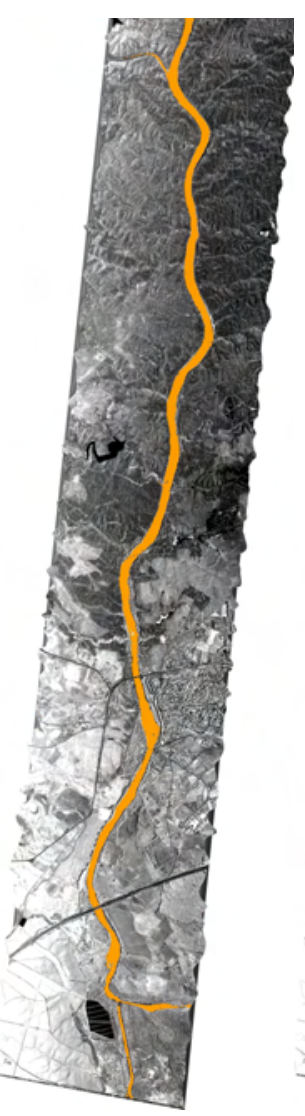

B : River

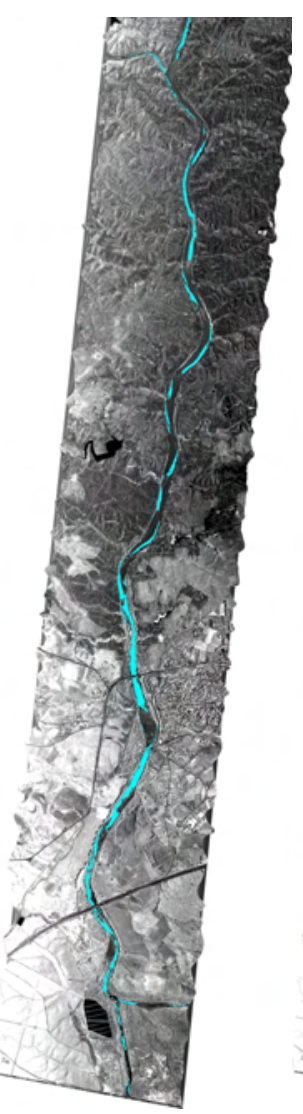

C: Water

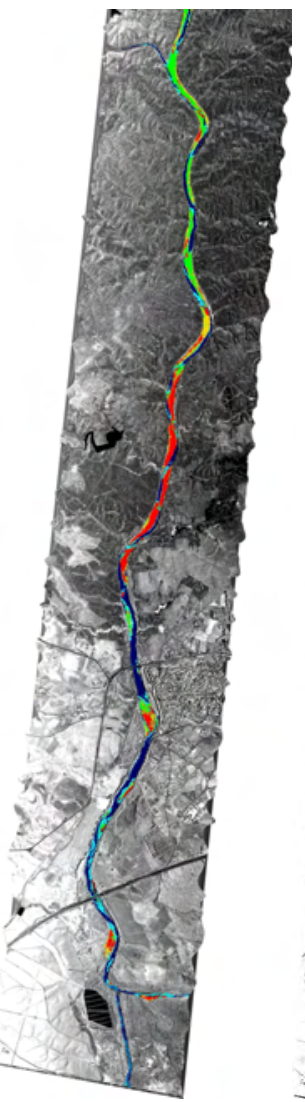

D

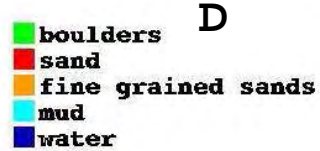

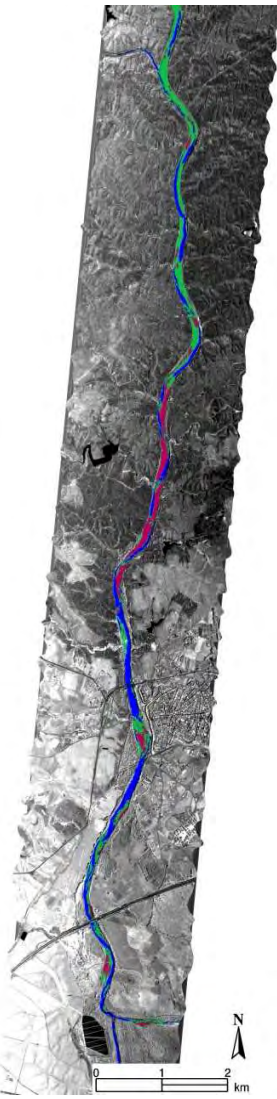

$\mathbf{E}$

Figure 2.5. A: False colour composite image with Hymap channels 16 (o.6755 $\mu \mathrm{m}), 26$ $(0.8188 \mu \mathrm{m})$ and $108(2.1917 \mu \mathrm{m})$. B: Mask for the flow path. C: Mask for water. D: Map of fluvial sediments. E: Map of coatings of precipitates from acid water with dissolved iron sulphide over river sediments. Legend as map on Figure 2.2L.

Figura 2.5. A: Composición en falso color con los canales Hymap 16 (o.6755 $\mu \mathrm{m}), 26$ (o.8188 $\mu \mathrm{m})$ y $108(2.1917 \mu \mathrm{m})$. B: Máscara para el cauce del río. C: Máscara para el agua. D: Mapa de sedimentos fluviales. E: Mapa de costras en sedimentos, con minerales que precipitan a partir de aguas ácidas con productos disueltos procedentes de la meteorización de sulfuros de hierro. Misma leyenda que el mapa de la Figura 2.2L.

Identification of correct water types is critical to the mapping process. The spectral signature of acidic water can be misidentified as a number of hydrated pyrite weathering products. Moreover, margins of pebble river bars are often fine-grained sands covered with wet pyrite mud, narrow belts of efflorescent salts, or drying vegetation, all of which have significant spectral features which can be misinterpreted if not carefully evaluated. Some plants, which may root on the muddy or sandy bottom of a river, are considered typical of acidic waters (e.g. Klebsormidium sp.), and can 
influence the spectral mixture of water, particularly when water levels are low and transmisivity of the water is high. The muddy or sandy bottom can also contribute to the spectral response of shallow acidic water if there is no vegetation. A false colour composite using a channel in the blue wavelength range, a channel at the maximum vegetation spectral response, and a channel between $2.2 \mu \mathrm{m}$ and $2.3 \mu \mathrm{m}$ (Figure 2.5A) helps to identify water among the wavy shades coming from the MNFTs on the masked flow path.

The seventh MNFT computed from the whole Hymap image identifies efficiently water; a mask was then built from those data (Figure 2.5C). The flow path mask and the water mask were combined into a single mask used to map emerged (un-inundated) river sediments. MNFTs were again computed under this flow path, excluding water (Figure 2.3). After the Pixel Purity Index procedure and n-dimensional analysis, the populations which are going to be the end members for input to the Spectral Angle Mapper were identified and the final map of the river flow path was constructed. Using the same procedure for subscenes within a scene yields somewhat different results. A general map was built for the flight line (Figure 2.5D).

Field observation identified the mapped areas from Hymap data as mainly related to river sediments (Riaza et al., 2012a). However, the spatial pattern of both river sediments and coatings of precipitates from acid water with dissolved sulphate and metals, are strongly related. Therefore, the spectra used as end-members for the maps, both of mine waste and river sediments, are mineralogically diagnosed with a reference spectral library of minerals involved in pyrite weathering (Crowley et al., 2003). The resulting map of mineral coatings permits interesting observations on climate dependent patterns using Hymap imagery during subsequent years (Figure 2.5E).

\subsection{AUTOMATED MODIFIED GAUSSIAN MODEL: A NEW EXPLORATION METHOD}

The application of the Automated Modified Gaussian Model (AMGM) to the analysis of a spectral signal was first used on pyroxene characterization (Sunshine et al., 1993) and on sediment physical properties and microphytobenthos analysis (Verpoorter et al., 2009), but the application of this technique is rather new in the geological mapping of acid mine drainage affected areas. 
The Spectral Derivative Automated Model (SDAM) is a serial of routines designed to deconvolve the continuum-removed spectra of a hyperspectral image into a sum of Gaussian curves, redrawing the reflectance spectra in order to be easily analyzed with derivative analysis procedures. Derivatives of spectra are computed to determine the wavelength of the main absorption features (Figure 2.6). To achieve quantitative estimations from the Gaussian curve, the main absorptions and their wavelength are extracted and analyzed for three selected geological units (Figure 2.7) (Buzzi et al., 2011).

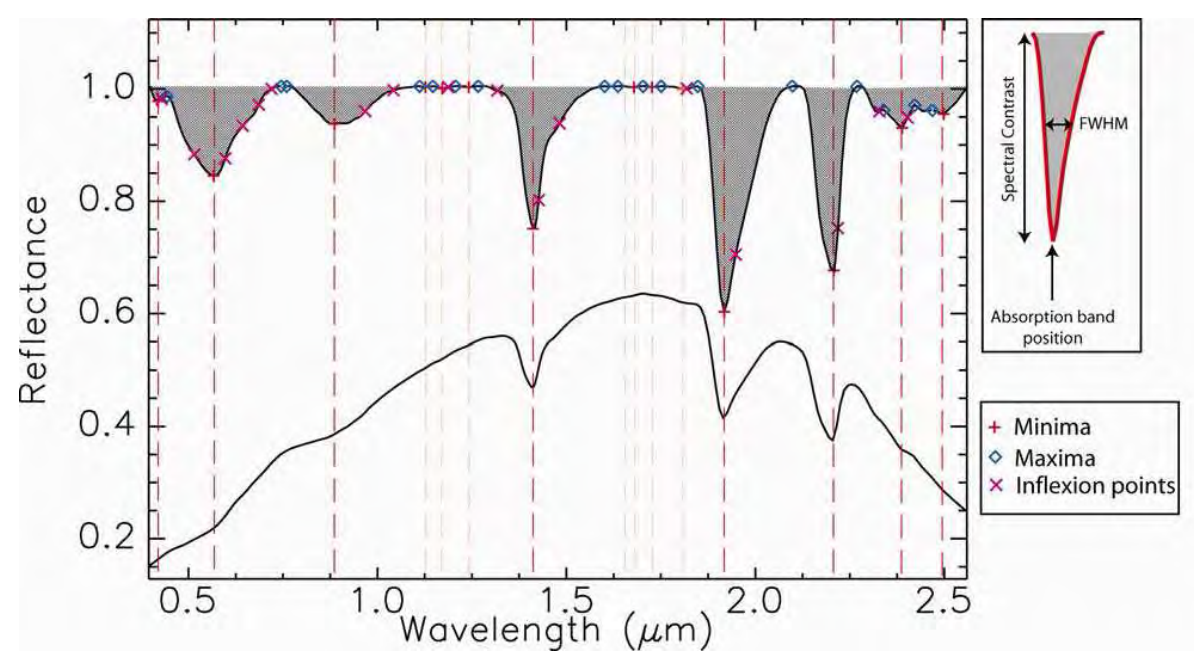

Figure 2.6. Spectra of soil (below). Derivative of the spectra of soil (above). The derivative extracts minimum, maximums and inflexion points from the shape of the spectra. On a single deep absorption position of electromagnetic energy on a spectra: expressions of Spectral Contrast, and Full Width at Half Maximum (FWHM). (in Verpoorter et al., 2009).

Figura 2.6. Espectro de suelo (abajo). Derivada del espectro de suelo (arriba). La derivada extrae puntos máximos, mínimos y de inflexión en la forma del espectro. En una banda de absorción de energía electromagnética en un espectro: posición de la longitud de onda, expresión del Contraste Espectral, y de la Anchura Total a Mitad del Máximo (FWHM). (in Verpoorter et al., 2009).

SDAM produces a set of images with the same number of bands than the original hyperspectral image. The resulting set gathers the most relevant parameters (absorption depth, full width at half maximum -FWHM and asymmetry factor) corresponding to the main absorption features. Bands without absorption features remain blind (Figure 2.8). 

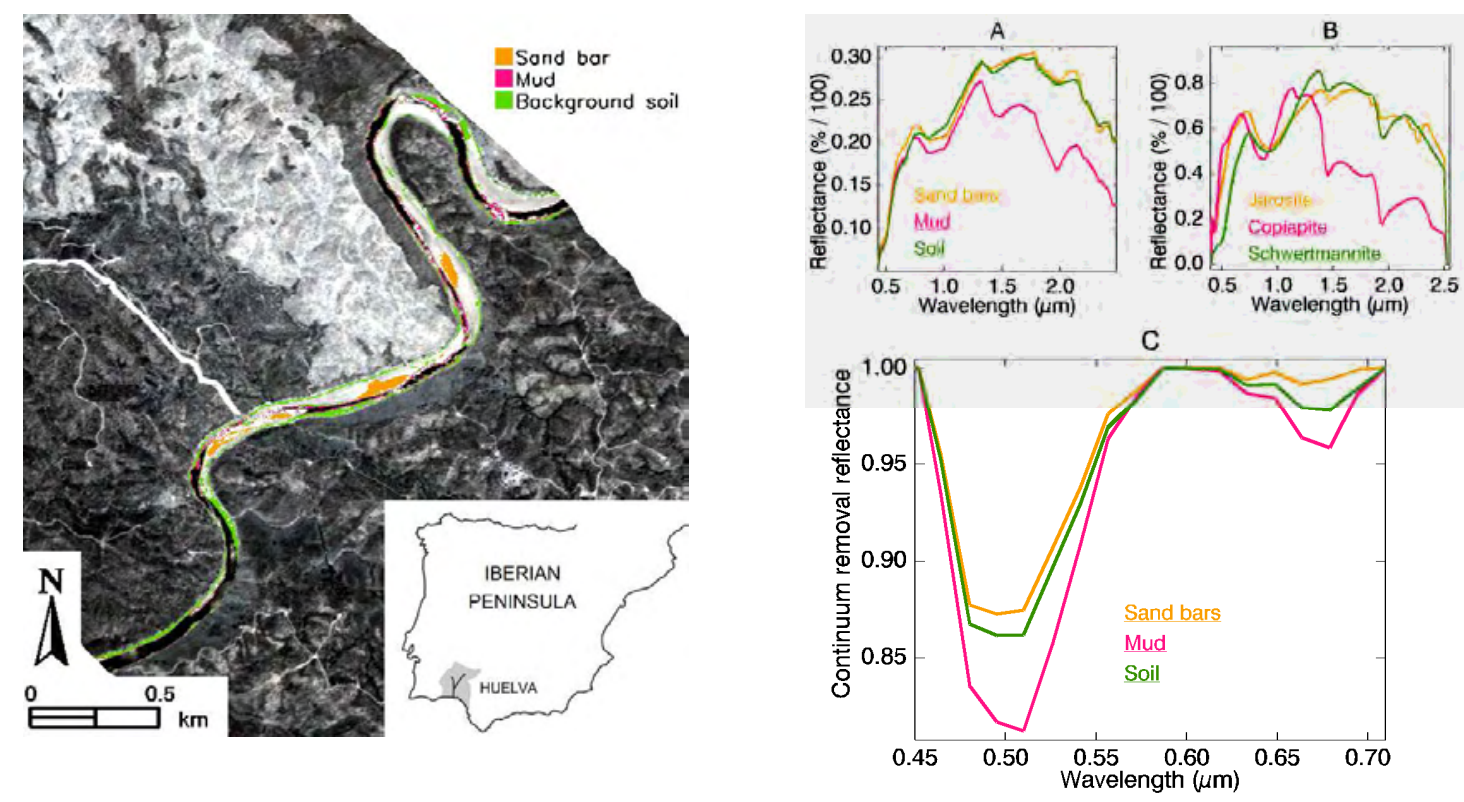

Figure 2.7. Geological units mapped from Hymap data. A: Hymap spectra of the selected geological units. B: Spectra of minerals diagnosed for the Hymap geological units included in the reference mineral spectral library (Crowley et al., 2003) for pyrite weathering products. C: Continuum removed spectra for the Hymap spectra of the mapped geological units.

Figura 2.7. Unidades geológicas cartografiadas con datos Hymap. Espectros extraídos de las imágenes Hymap correspondientes a las unidades geológicas cartografiadas incluidos en la espectroteca de referencia de minerales producto de la meteorización de piritas (Crowley et al., 2003). C: Espectros en los que se ha eliminado el continuo, de los espectros Hymap de las unidades geológicas cartografiadas.

The Spectroscopic Derivative Analysis and Automated Modified Gaussian Model are applied to the spectra from three geological units mapped from Hymap data to locate the features at their minimum absorptions. Only the nineteen Hymap channels within the visible wavelength range are used because of their good signal/noise ratio, apart from certain limitations of the software to work with a high number of bands. 


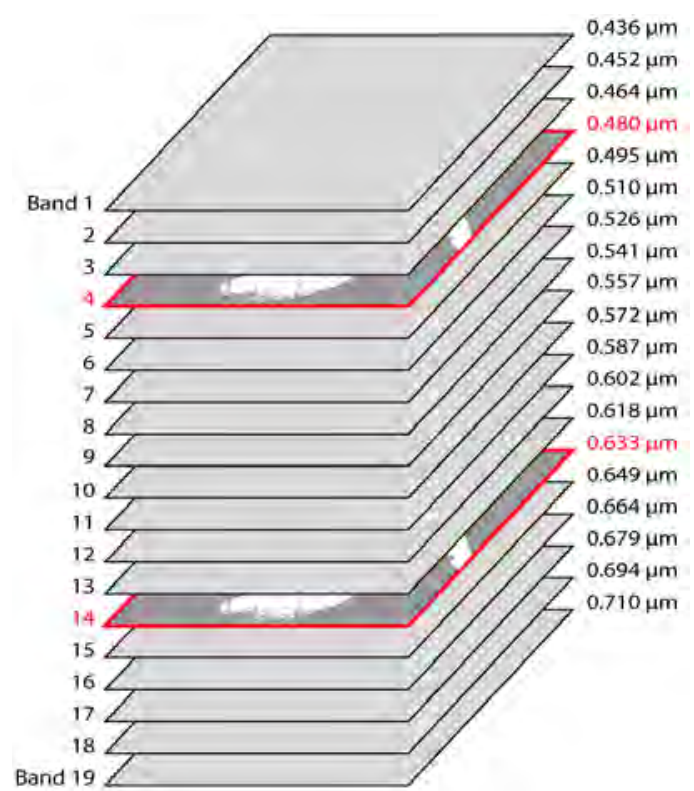

Figure 2.8. Layers of data product of an SDA-processed Hymap image (only VIS channels) identified by wavelength. The red wavelength layers correspond to non-zero information channels.

Figura 2.8. Capas de datos producto de una imagen Hymap sometida a Derivadas Espectrales Avanzadas (SDA) (sólo canales en el intervalo de longitudes de onda del visible VIS) identificados por su longitud de onda. Las capas identificadas en rojo corresponden a canales con información distinta de cero.

\subsubsection{EVALUATION OF PARAMETERS FROM SPECTROSCOPIC DERIVATIVE}

\section{ANALYSIS ON HYMAP SPECTRA FROM CONTAMINATED RIVER SEDIMENTS}

The previous image processing maps (Riaza and Müller, 2010) gather geological units along the river path, from which three are selected to test using SDAM: sand bars, mud surfaces and soil over the background rock.

The mineral diagnosis of the coatings covering the river sediments using the reference spectral library for pyrite oxidation products (Crowley et al., 2003; RSI, 2000) reveals the presence of iron oxides and sulphate. Sand bars are covered by jarosite, schwertmannite and goethite. The mud along the edges of sand bars is covered by alunite, copiapite and szmolnokite. The regional background soil is dominated by schwertmannite, goethite and jarosite (Figure 2.7A and Figure 2.7B).

The three identified geological units show a similar trend on the reflectance continuum removed spectrum in the visible wavelength range (Figure $2.7 \mathrm{C}$ ), with a deep and narrow absorption feature centred at $0.50 \mu \mathrm{m}$ and a smooth absorption at $0.67 \mu \mathrm{m}$. Both correspond to the spectral features of ferric cations $\mathrm{Fe}^{3+}$ bearing minerals, at 0.50 
$\mu \mathrm{m}$ and at $0.86 \mu \mathrm{m}$ (Hunt et al., 1976). Sulphate is the dominant mineralogy in coatings that cover the Odiel river path sediments. The dominant absorption features present in the visible wavelength range is centred at $0.6 \mu \mathrm{m}$ (Figure 2.7B).

When deconvolving the continuum removed spectra into Gaussian curves, different features corresponding to characteristic absorptions come out, which cannot be appreciated without deconvolution (Figure 2.9). The absorption features near $0.45 \mu \mathrm{m}$ seem to correspond to a combination of ferrous and ferric ions, whereas the absorptions located near $0.65 \mu \mathrm{m}$ correspond to the ferric ion (Crowley et al., 2003).

Geoloaical units
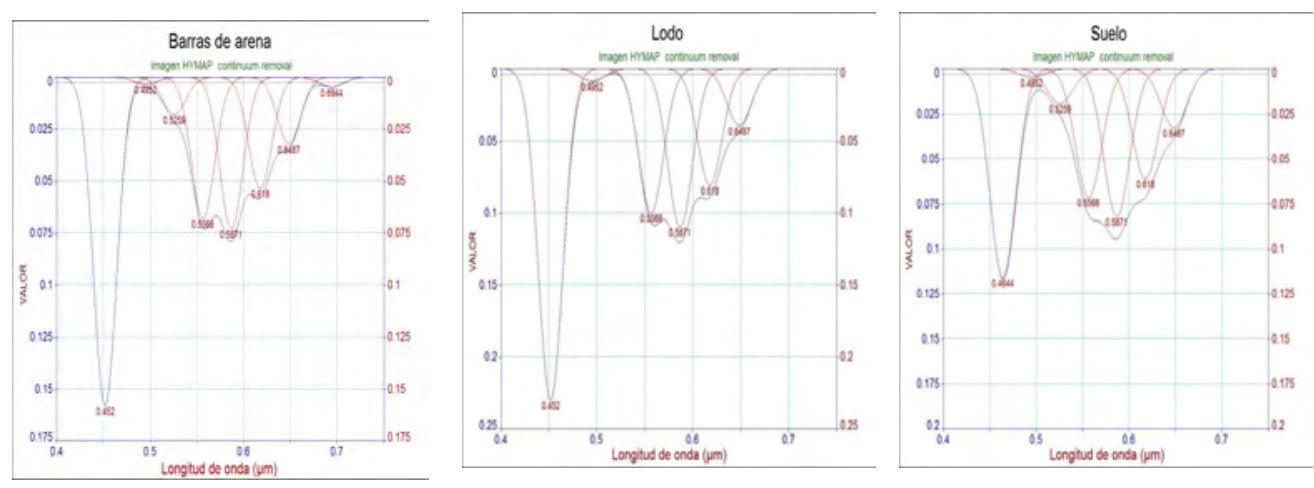

\section{Reference minerals}
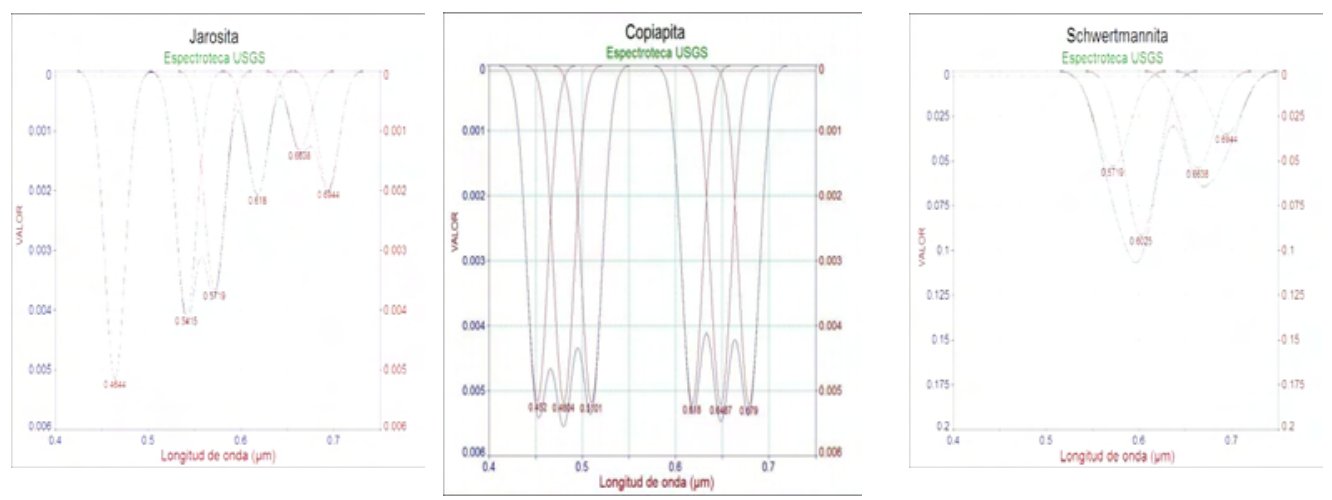

Figure 2.9. Spectra after continuum removal of Hymap geological units and reference minerals diagnosed as dominant on the corresponding geological unit with the reference spectra library on pyrite weathering products (Crowley et al., 2003).

Figura 2.9. Espectros después de eliminar el continuo, de las imágenes Hymap para las unidades geológicas cartografiadas, $y$ de los minerales de referencia diagnosticados como dominantes para cada unidad geológica con la espectroteca de minerales de oxidación de pirita de referencia (Crowley et al., 2003). 

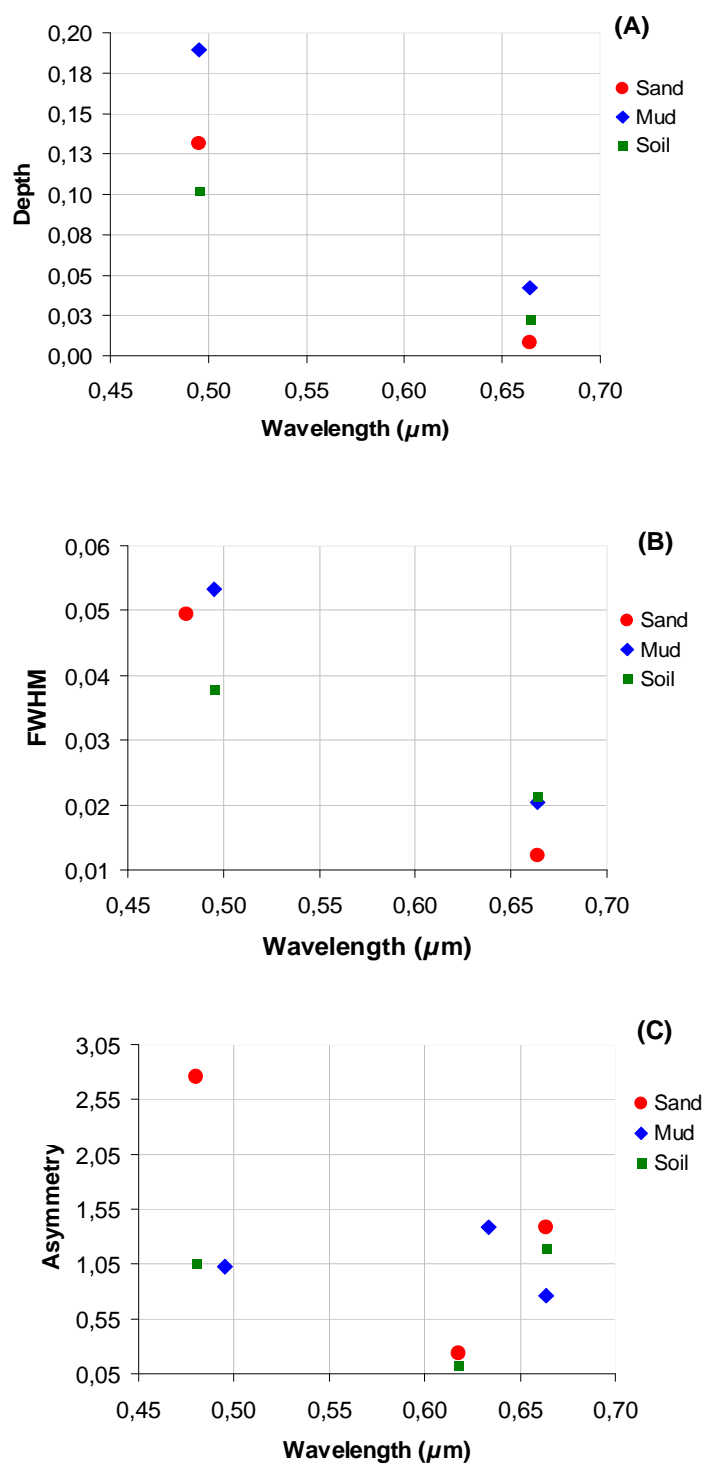

Figure 2.10. Linear regression between the wavelength of the critical absorption features versus the absorption parameters derived from the continuum removal of Hymap spectra of the geological units.

Figura 2.10. Regresión lineal entre las longitudes de onda de las absorciones características y los parámetros de absorción derivados de la eliminación del continuo en los espectros Hymap correspondientes a las unidades geológicas.

The wavelengths of the absorption centres in the spectra of the selected geological units are compared with their diagnosed mineral reference from the USGS spectral library (Crowley et al., 2003) to test the assumption of a monomineral diagnosis that simplifies calculations and interpretations. Regression coefficients indicate a good correlation between the diagnosed mineral and their reference mineral spectra. 
The absorption depth coincides for the three selected geological units at $0.4952 \mu \mathrm{m}$ and $0.6638 \mu \mathrm{m}$ (Figure 2.10A), due to the presence of $\mathrm{Fe}^{3+}$ cations. The absorption of mud at $0.4952 \mu \mathrm{m}$ is deeper than the rest, whereas at $0.6638 \mu \mathrm{m}$ is weaker.

Relevant Full Width at Half Maximum (FWHM) peaks from the spectra of the three selected geological units (Figure 2.10B) occur around $0.49 \mu \mathrm{m}$ and at $0.66 \mu \mathrm{m}$. The FWHM of sand bars around $0.49 \mu \mathrm{m}$ is shifted towards lower wavelengths. Sand bars also show low FWHM at $0.6638 \mu \mathrm{m}$.

The absorption band asymmetry for the three geological units displays around 0.485 $\mu \mathrm{m}$ (Figure 2.10C) and at $0.63 \mu \mathrm{m}$. The asymmetry parameter for the three geological units coincides at $0.6638 \mu \mathrm{m}$. Sand bars shows a high value around $0.485 \mu \mathrm{m}$ and tends to join soil background around $0.63 \mu \mathrm{m}$ and at $0.6638 \mu \mathrm{m}$. The absorption band asymmetry of the Hymap spectra of mud differs from the other geological units around $0.63 \mu \mathrm{m}$ and at $0.6638 \mu \mathrm{m}$.

\subsection{CONCLUSIONS}

The main technical features of the Hymap airborne and Hyperion spaceborne hyperspectral sensors used in this study are described. Moreover, the preprocessing chain to convert raw data to reflectance on both sensors is drafted.

The interpretation of hyperspectral remote sensing requires specific algorithms able to manage high dimensional data. The image processing methods to extract information are described, and the sequence of algorithms used to produce maps, both on mine sites and river paths.

A new exploration method, the Automated Modified Gaussian Model, intends to estimate further spectral variability explaining the geological meaning of the Hymap spectra associated to the units of river sediments mapped. 


\section{CHAPTER 3}

\section{MAPPING PYRITE WEATHERING PRODUCTS OVER A RECOVERING MINE SITE WITH HYPERSPECTRAL AIRBORNE HYMAP DATA (SOTIEL, HUELVA, SW SPAIN)}

\subsection{INTRODUCTION}

Massive sulphide deposits have been mined in the Iberian Pyrite Belt for at least 5000 years (Leblanc et al., 2000). Mining activity of these minerals implies the removal of large amounts of rocks, exposing unstable mineral substances to the air that weather when exposed to the atmosphere, following a well-known sequence of secondary minerals (Buurman, 1975). The mineralogical changes involved in mine waste weathering are controlled by climate and geomorphology (Riaza and Müller, 2010; see Chapter 1.3). In this case, the mine recovery activities dominate the mineral growth.

The weathering of iron sulphide releases acid waters and heavy metals into the environment (see Chapter 1.3). The exposure to the atmosphere of massive sulphides generates the oxidation of these minerals, which are highly ephemeral, dissolving and re-precipitating rapidly, generating secondary minerals such as oxides and hydrated sulphates. The mineralogical, temporal evolution and spatial pattern of the secondary minerals, growing over mine waste, differs from mud tailings to rock piles, and also varies with landforms on waste piles and dumps, along with the mine recovery works.

Hyperspectral Hymap data are used to map the extension and evolution of the pyrite weathering products at the mine site, related to recovery activities. Hyperspectral image processing provides a fast and accurate diagnosis of the secondary minerals growing on mine waste and its mineralogical changes, mapped as a result of Hymap flights in the summers of 2005, 2008 and 2009 (Buzzi et al., 2009, 2010a, 2010b).

\subsection{THE INFLUENCE OF CLIMATE}

Climate influences the environmental impact on mines which exploit massive sulphide deposits. Temperature and humidity control evaporation. Evaporation is scarce in semi-arid and arid climates. In arid climates, the acidity and total concentration of 
heavy metals from mine operations in the environment is several orders of magnitude superior to temperate climates. Seasonal variations in the chemistry of effluents from operating mines are experienced, with peaks of total concentrations of metals dissolved in water during the summer (Seal and Hammarstrom, 2003).

The weathering behavior of the various wastes and the chemistry of associated drainage vary with the nature of the wastes. In general, if ferrous iron emerges from piles, the rapid oxidation reduces the $\mathrm{pH}$ of the effluents immediately.

In the Pyrite Belt, groundwater is scarce, and the water table is permanently low. The seasonal changes on mineralogy of the mineral coatings, over rock piles or mill tailings, are related directly to rainfall and temperature over the surface. The hydrological cycle begins with heavy intense rains in October (see Chapter 1.3), washing all surfaces, and diluting most of the soluble salts present. The rainfall rate during the rest of the year is low, with maximum temperatures in the summer. The process of oxidation and dehydration of the available iron sulphide progresses to reach a peak at the end of the summer. The pattern of the mineral coatings at this stage is a record of the available humidity and intensity of evaporation during the previous year. This mineral evolution controlled by climate was discovered from Hymap data over the mine site of Sotiel, with data from 1999 to 2005 (Riaza and Müller, 2010).

This chapter intends to add data to the environmental model of mineral coatings over mine waste, in a mine under recovery, using Hymap data from 2008 and 2009.

\subsection{DATA SET}

\subsubsection{IMAGERY}

Hymap data were acquired over the Odiel river path on $17^{\text {th }}$ July 2005, $4^{\text {th }}$ August 2008 and $13^{\text {th }}$ August 2009. Hymap is an airborne hyperspectral sensor with 126 wavebands, from 436 to $2485 \mathrm{~nm}$, with a spectral resolution of $10-20 \mathrm{~nm}$. Its spatial resolution is 5 $m$ (Table 1.1). The Hymap pre-processing is described in Chapter 2.3. The image processing sequence, to provide a map of mine sites, is described in Chapter 2.5 and 2.7 .

\subsubsection{FIELD AND LABORATORY SPECTRA}

Field spectral measurements were taken at 287 field locations at the mine sites, using an ASD FieldSpec 3 Spectrometer (ASD Inc., Boulder, Co, USA), from 2008 to 2011, for 
thematic purposes, apart from calibration. An additional 45 spectral measurements were made in the dark room on selected rock, mud or soil samples. This measures the ground reflectance spectra, covering the wavelength range from $350 \mathrm{~nm}$ to $2500 \mathrm{~nm}$. Its coverage, resolutions and operational procedures are summarized in Chapters 1.7.2 and $1.7 \cdot 3$.

\subsubsection{ADDITIONAL DATA}

Selected representative sediment and rock samples were analysed using X-ray diffraction. Selected samples of rocks, mud and dust were also collected for conventional mineralogical analysis.

\subsection{THE MINE SITE FACILITIES IN SOTIEL}

Industrial operations at most metallic mine sites in the Iberian Pyrite Belt have now ceased. Most mine facilities have been abandoned and are under the environmental control of the authorities. They are numerous and the wide regional exposure of abandoned mine waste makes the Iberian Pyrite Belt an ideal field for testing environmental monitoring methods. The mine works in Sotiel are spread along the River Odiel on its middle course. From 1991 to 2000, the ore-processing plant of the Sotiel mine site roasted industrial sulphide waste to produce sulphuric acid, which was delivered to nearby coastal industrial facilities.

The operating underground mine works are displayed along the River Odiel (Figure 3.1). A conveyor belt transported the ore from the mine, uphill to the ore-processing plant. Ashes from the ore processing plant were impounded on an adjacent dam. Pyrite mud was stored in another dam to the south, draining into the River Odiel, upstream from the mine works. Along the banks of the river, secondary minerals were precipitated from acid water along this portion of the river.

In the year 2001, the industrial activities ended. The rehabilitation of the mine site began in 2006 by the ashes dam. The rehabilitation concept intends to isolate the contaminated matter, preventing their dispersion into the environment. The water of the dam is drained and the bottom is protected to prevent water infiltration, which can activate the oxidation process of pyrite. The dry bottom is sealed with a repeated sandwich of several layers, including overlying a textile sheet, a clay-rich layer, an iron oxide rich layer, and an organic matter rich layer. Grass is planted with Poaceae over the final organic matter layer, to restore ordinary soil development. The dry grass $\left(4^{\text {th }}\right.$ 


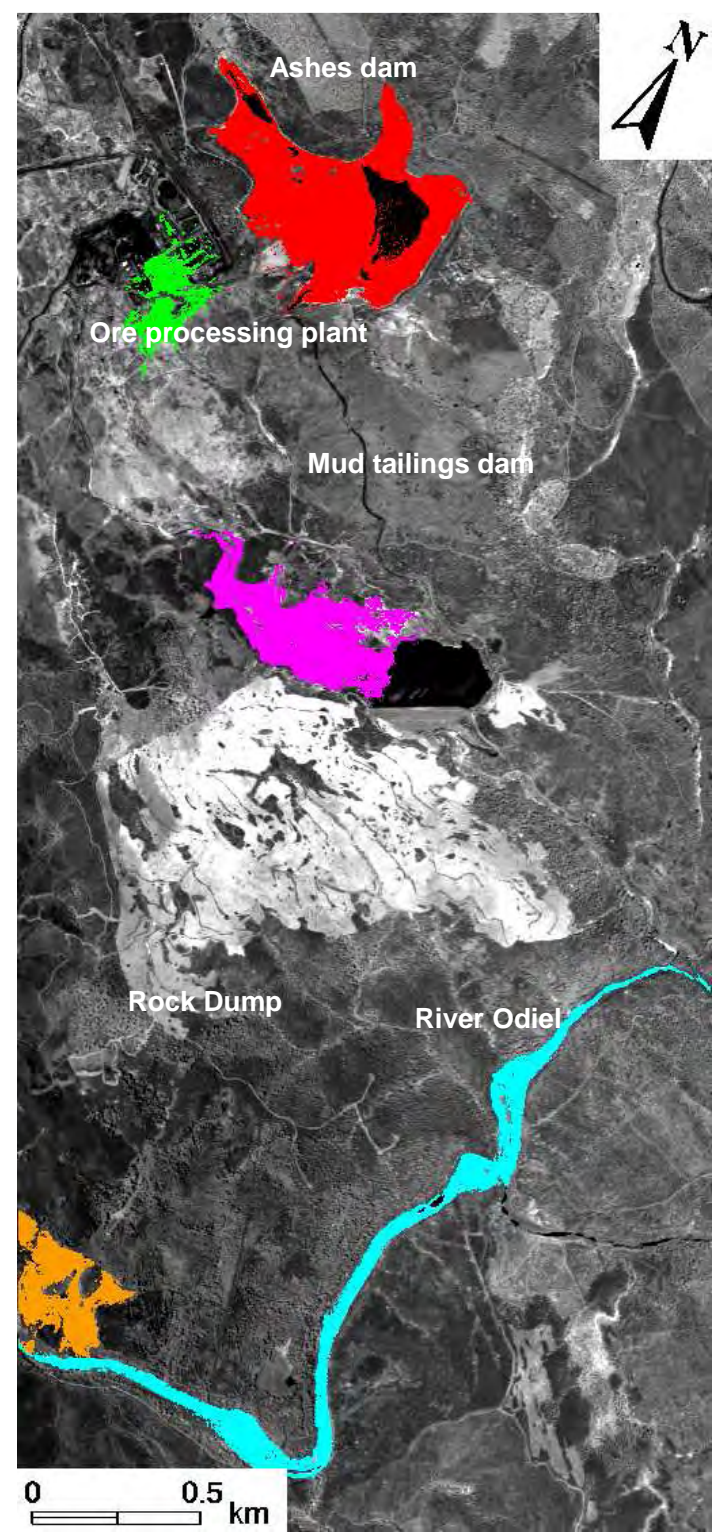

Figure 3.1. Location of domains within the Sotiel mine site along the bank of the River Odiel.

Figura 3.1. Situación de ambientes estudiados en la mina de Sotiel a orillas del río Odiel.

August 2008 flight) growing in spring is cut in the summer, to prevent fires $\left(13^{\text {th }}\right.$ August 2009 flight).

The rehabilitation of the mill tailings dam and the dismantling of the ore-processing plant began in autumn 2008 and winter 2009. By $13^{\text {th }}$ August 2009, the mud had been removed from the dam, and the bottom was in the process of being drained and consolidated before the operation of machines. In the following years, the bottom was 
sealed, the dam filled with waste from the mine dumps by the river, and the final surface was covered with yellow sand.

Available humidity, whether through water supplies to the dams during the maintenance of the facilities, or by climate, have a strong influence on the pattern and mineralogy of the coatings on the surface of the waste. Previous work on the temporal evolution of mineral coatings over mine waste, both on dumps and mill tailings, at the mine site of Sotiel in 1999, 2004 and 2005, suggested that such mineral coatings could be used as a geological record of short-term climate variability (Riaza and Müller, 2010).

Available humidity, whether through water supplies to the dams during the maintenance of the facilities, or by climate, have a strong influence on the pattern and mineralogy of the coatings on the surface of the waste. Previous work on the temporal evolution of mineral coatings over mine waste, both on dumps and mill tailings, at the mine site of Sotiel in 1999, 2004 and 2005, suggested that such mineral coatings could be used as a geological record of short-term climate variability (Riaza and Müller, 2010).

\subsection{CHANGE DETECTION 2005-2008-2009 AT THE SOTIEL MINE SITE}

\subsubsection{THE DAM OF ASHES}

According to the imagery, in June 2005, the northern ashes pond (Figures 3.2A and3.2D) was deeply oxidized (Figure 3.2A, yellow circle). Hematite and goethite are widespread on the surface, and more hydrated phases occur comparatively along rills as pickeringite or paracoquimbite (Figure 3.2A, cyan circles). The same spatial pattern is displayed on a small scale (Figures $3.3 \mathrm{~B}$ and $3.3 \mathrm{C}$ ). Small voids on the hematitic crust host hydrated sulphate, which has precipitated from the last solution and precipitation event.

Field spectra (Figure 3.3A) reveal dominant oxidized mineralogical phases in 2005, according to the results of the Hymap image processing. Whitish hydrated sulphates spread over the hematitic crust are diagnosed as alunite (Figures $3.3 \mathrm{~B}$ and $3.3 \mathrm{C}$ ). Phosphate is a chemical component used in the mineralurgy of ore processing in the plant. 

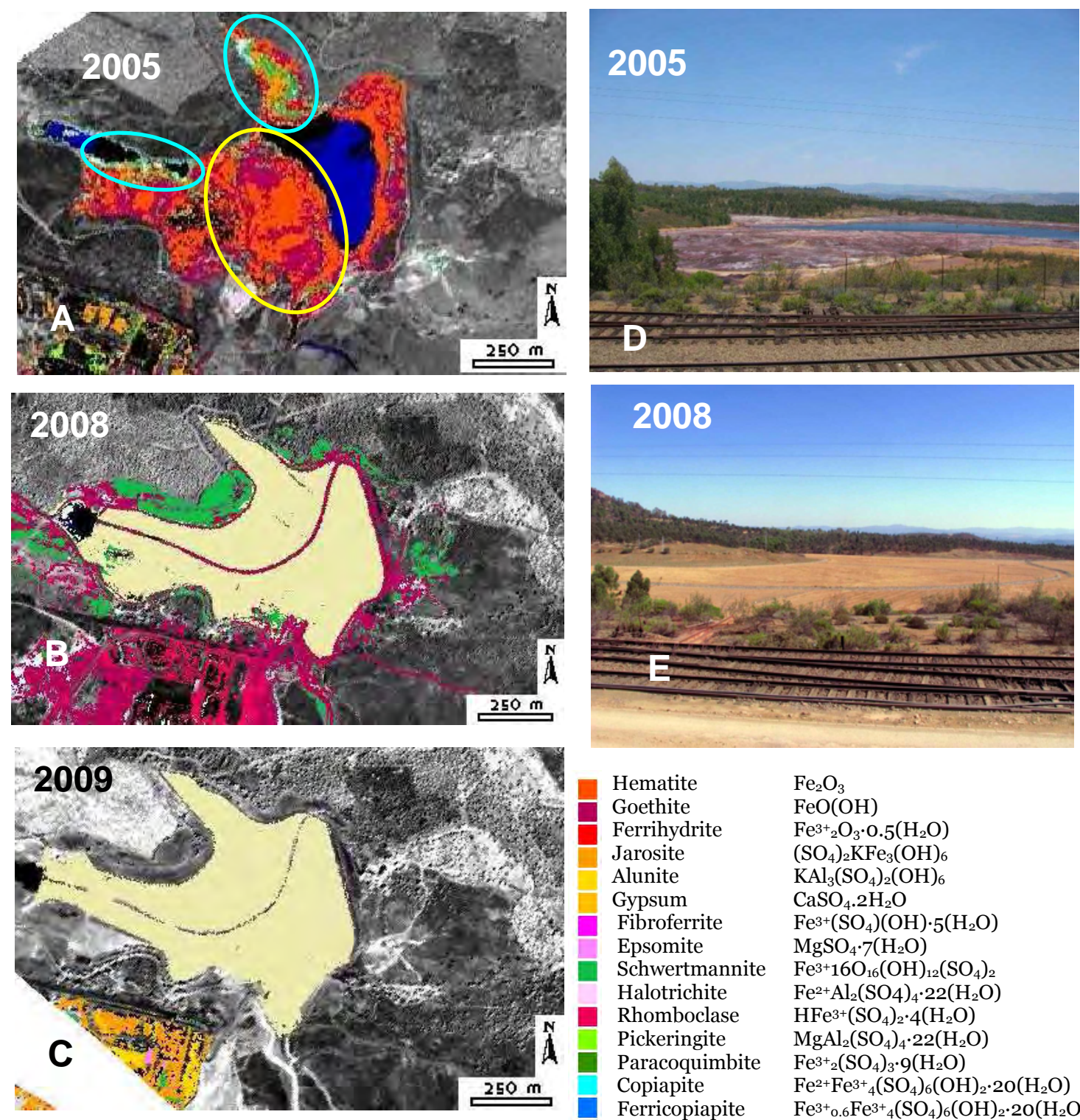

Hematite
Goethite
Ferrihydrite
Jarosite
Alunite
Gypsum
Fibroferrite
Epsomite
Schwertmannite
Halotrichite
Rhomboclase
Pickeringite
Paracoquimbite
Copiapite
Ferricopiapite
Szmolnokite
Rozenite
Melanterite

$\mathrm{Fe}_{2} \mathrm{O}_{3}$
$\mathrm{FeO}(\mathrm{OH})$
$\mathrm{Fe}^{3+}{ }_{2} \mathrm{O}_{3} \cdot \mathrm{O} \cdot 5\left(\mathrm{H}_{2} \mathrm{O}\right)$
$\left(\mathrm{SO}_{4}\right)_{2} \mathrm{KFe}_{3}(\mathrm{OH})_{6}$
$\mathrm{KAl}_{3}\left(\mathrm{SO}_{4}\right)_{2}(\mathrm{OH})_{6}$
$\mathrm{CaSO}_{4} \cdot 2 \mathrm{H}_{2} \mathrm{O}$
$\mathrm{Fe}^{3+}\left(\mathrm{SO}_{4}\right)(\mathrm{OH}) \cdot 5\left(\mathrm{H}_{2} \mathrm{O}\right)$
$\mathrm{MgSO}_{4} \cdot 7\left(\mathrm{H}_{2} \mathrm{O}\right)$
$\mathrm{Fe}^{3+} 6 \mathrm{O}_{16}(\mathrm{OH})_{12}\left(\mathrm{SO}_{4}\right)_{2}$
$\mathrm{Fe}^{2+} \mathrm{Al}_{2}\left(\mathrm{SO}_{4}\right)_{4} \cdot 22\left(\mathrm{H}_{2} \mathrm{O}\right)$
$\mathrm{HFe}^{3+}\left(\mathrm{SO}_{4}\right)_{2} \cdot 4\left(\mathrm{H}_{2} \mathrm{O}\right)$
$\mathrm{MgAl}_{2}\left(\mathrm{SO}_{4}\right)_{4} \cdot 22\left(\mathrm{H}_{2} \mathrm{O}\right)$
$\mathrm{Fe}^{3+}{ }_{2}\left(\mathrm{SO}_{4}\right)_{3} \cdot 9\left(\mathrm{H}_{2} \mathrm{O}\right)$
$\mathrm{Fe}^{2+} \mathrm{Fe}^{3+}\left(\mathrm{SO}_{4}\right)_{6}(\mathrm{OH})_{2} \cdot 2 \mathrm{O}\left(\mathrm{H}_{2} \mathrm{O}\right)$
$\mathrm{Fe}^{3+}{ }_{0.6} \mathrm{Fe}^{3+}{ }_{4}\left(\mathrm{SO}_{4}\right)_{6}(\mathrm{OH})_{2} \cdot 2 \mathrm{O}\left(\mathrm{H}_{2} \mathrm{O}\right)$
$\mathrm{Fe}\left(\mathrm{SO}_{4}\right) \cdot \mathrm{H}_{2} \mathrm{O}$
$\mathrm{Fe}^{2+}\left(\mathrm{SO}_{4}\right) \cdot 4\left(\mathrm{H}_{2} \mathrm{O}\right)$
$\mathrm{Fe}^{2+}\left(\mathrm{SO}_{4}\right) \cdot 7\left(\mathrm{H}_{2} \mathrm{O}\right)$

Figure 3.2. Dam of ashes. A, B and C: Maps compiled from Hymap data on the minerals product of oxidation and dehydration of sulphide sludge, on the three available flights on the northern ashes dam. Increasing reddish colours suggest intense oxidation. Bluish and greenish colour concentrate on hydrated areas.

Figura 3.2. Balsa de cenizas. A, B y C: Mapas elaborados con datos Hymap de minerales producto de oxidación y deshidratación de lodos de sulfuros, en los tres vuelos disponibles sobre la balsa de cenizas septentrional. El predominio de colores rojizos indica oxidación intensa. Los colores azulados y verdosos se concentran en zonas con sulfatos hidratados. 

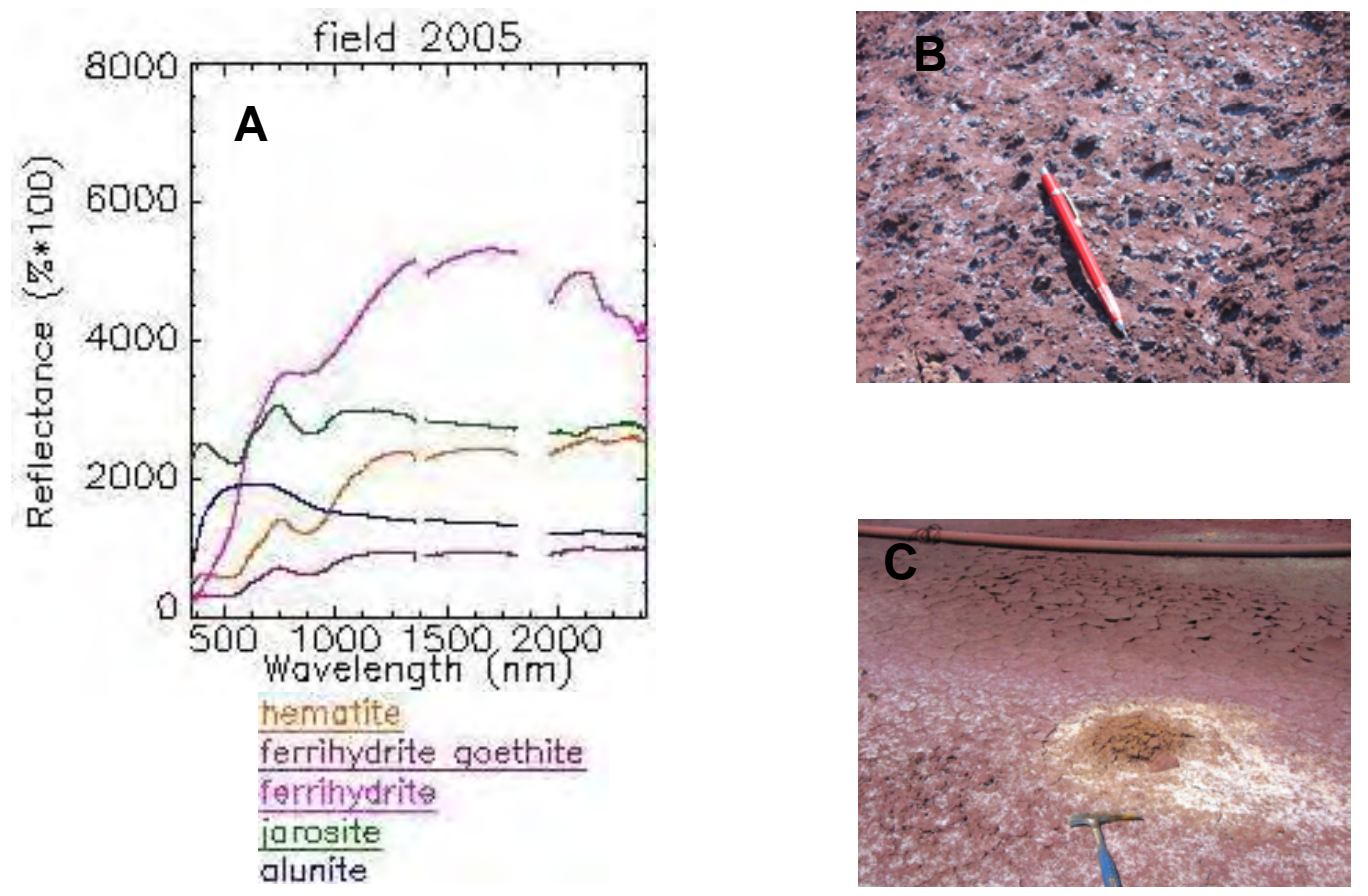

Figure 3.3. Dam of ashes. A: Field spectra measured in several locations of the dam of ashes. B: Detail of small hydrated sulphate whitish growth in a haematitic crust.

C: Whitish hydrated sulphate around an obstacle in the dominantly reddish hematitic crust.

Figura 3.3. Balsa de cenizas. A: Espectros de campo tomados en varios puntos de la balsa de cenizas. B: Detalle de crecimiento de sulfatos hidratados blancos sobre una costra hematítica rojiza. C: Sulfato blanquecino rodeando un obstáculo sobre costras hematíticas rojizas.

The rehabilitation of the dam of ashes began in 2006, and was completed by the summer of 2008. All ashes were removed, the water was drained, and the whole area was refilled, preventing water infiltration. In August 2008, the surface of the former dam of ashes was covered by high dry grass (Figures $3.4 \mathrm{C}$ and $3.4 \mathrm{E}$ ). In contrast, the grass was cut in August of the following year, to avoid fires (Figure 3.4C). Field spectra (Figure 3.4A) show the spectral changes from a dominant hematitic crust in 2005 (Figure3.4B) to dry grass in 2008 (Figure 3.4C), and bare soil in 2009 (Figure 3.4D). The spectral behavior of dry grass covering the former dam of ashes in 2008 (Figure $3.4 \mathrm{E}$ ), was measured in the field (Figure $3.4 \mathrm{~F}$ ), showing a typical decedent vegetation spectral response. 

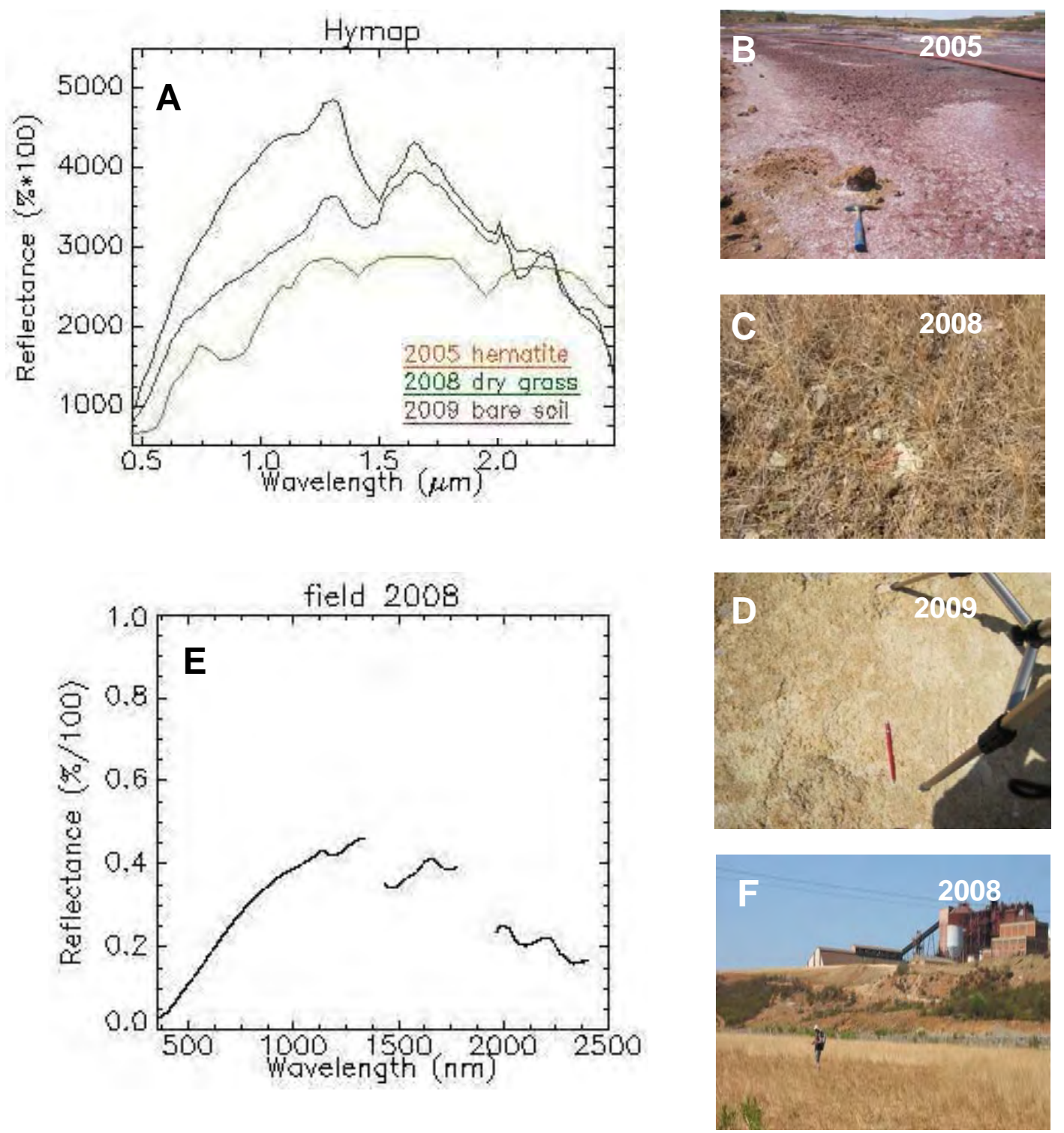

Figure 3.4. Dam of ashes. A: Hymap spectra of representative units in 2005, 2008 and 2009. B: Detail of dominant hematite coating on the dam of ashes in 2005, with spectra in A. C: Detail of dry grass covering the recovered former dam of ashes in 2008, with spectra in A. D: Detail of soil covering the former dam of ashes in 2009, with spectra in A. E: Field spectra from the dry grass in 2008 covering the former dam of ashes. F: View of the dry grass covering the former dam of ashes in 2008, with operator measuring spectra.

Figura 3.4. Balsa de cenizas. A: Espectros Hymap de cubiertas representativas en 2005, 2008 y 2009. B: Detalle de una costra predominantemente hematítica en la balsa de cenizas en 2005, con espectro correspondiente en $A$. C: Detalle de hierba seca que crece sobre la balsa de cenizas rehabilitada en 2008, con espectro en A. D: Detalle del suelo de la balsa de cenizas en 2009, con espectro en A. E: Espectro de campo de la hierba seca sobre la balsa de cenizas en 2008. F: Vista de la hierba seca cubriendo la balsa de cenizasen 20o8, con un operador midiendo espectros. 


\subsubsection{THE MINE DUMPS BY THE RIVER}

The historical mine works of Sotiel are located along the bank of the River Odiel. Holes, ponds and large dumps display for one kilometer along the river bank. Large dumps are arranged in a terraced landscape (Figure 3.5), whose geomorphology controls the secondary minerals coating the rock piles (Riaza and Müller, 2010). The flat tops of the dumps are stable surfaces, while the slopes host processes of run-off and washing during the rainy season, transporting debris downslope. The mobilized materials are deposited on the flat areas at the foot of the slopes as fans of variable dimensions. There was no industrial operation on the dumps along the river from 2005 to 2009. Only in 2010-2011, after the last available Hymap flight, part of the waste stored at the dumps by the river was used to refill the space of the mill tailings dam, which had been dried during the recovery process.

\subsubsection{Hymap maps}

In 2005, the flat tops of the terraces were covered with uniform coatings of hematite (Figure 3.5A, yellow circle), evidencing a high degree of oxidation. The slopes of the dumps are covered mainly by schwertmannite (Figure $3.5 \mathrm{~A}$, blue circles), while the local mill tailings ponds display an outer uniform coating of copiapite (Figure 3.5A, red circle). The path of the stream that reaches the dump from the north-west is covered by schwertmannite (Figure 3.5A, orange circle), and by goethite and hematite in the most elevated areas that surround it (Figure 3.5A, green circle).

In 2008, the flat tops of the dumps are still covered by hematite (Figure $3.5^{\mathrm{B}}$, yellow circles), but the slopes have been oxidized into goethite (Figure $3.5^{\mathrm{B}}$, blue circles). The flat areas at the foot of the slopes are covered by hydrated minerals, such as copiapite (Figure 3.5B, cyan circle). The slopes of outer piles host mainly schwertmannite (figure 3.5B, magenta circle) and narrow fringes of copiapite. The uniform copiapite surfaces, which appeared in 2005, are in the same position, but with slightly less extension (Figures $3.5 \mathrm{~A}$ and $3.5 \mathrm{~B}$, red circles). The tail of the dump along a stream hosts a schwertmannitic bottom (Figure $3.5^{\mathrm{B}}$, orange circle), with some hematite and goethite on both sides covering the steeper slopes of the banks (Figure $3.5^{\mathrm{B}}$, green circle).

In 2009, the flat tops of terraces are still coated by uniform surfaces of hematite (Figure $3.5 \mathrm{C}$, yellow circles), surrounded by a thin ribbon of goethite (Figure $3.5 \mathrm{C}$, blue circles). 

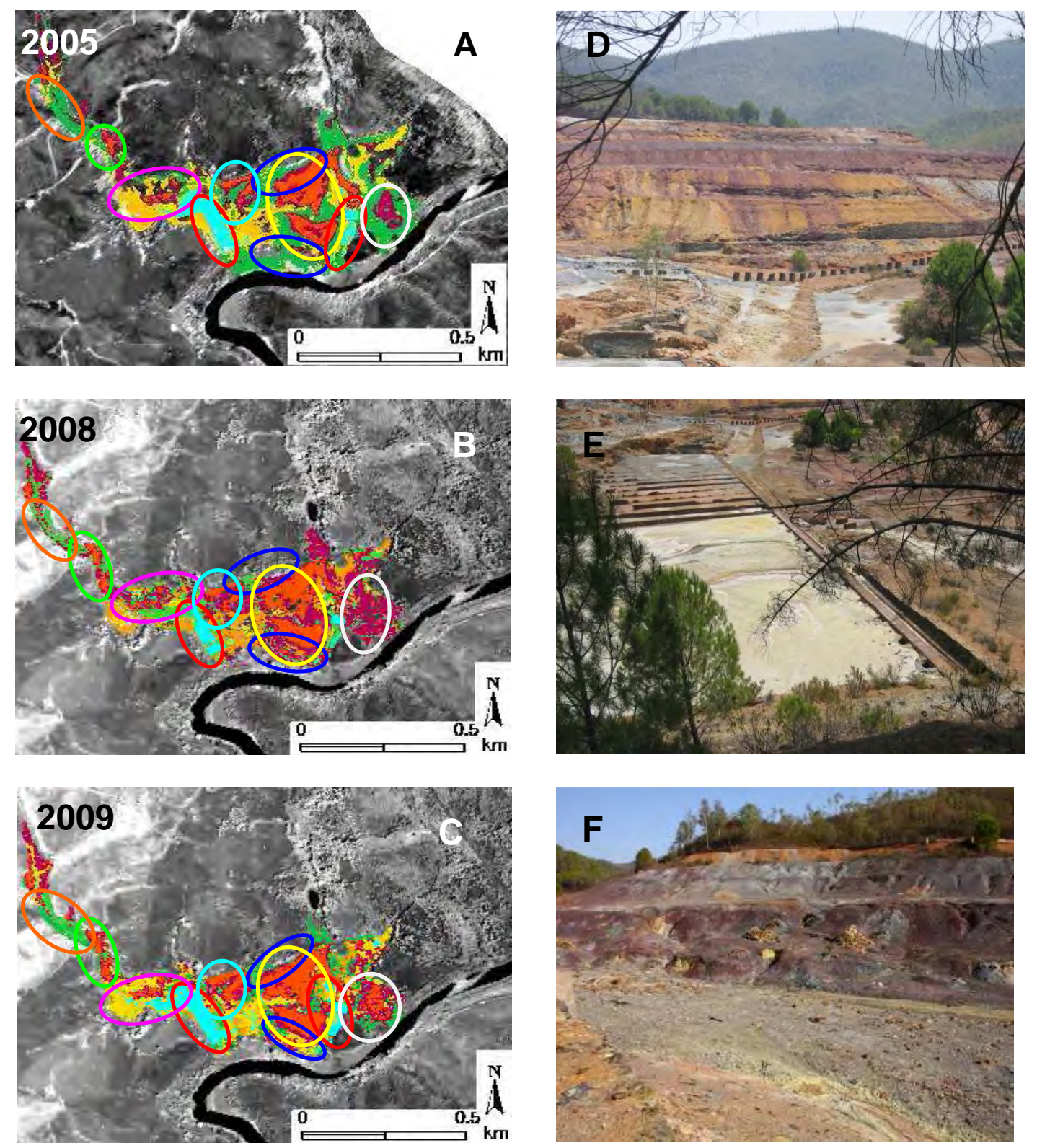

Figure 3.5. Mine dump by the river. A, B and C: Maps compiled from Hymap data on the minerals product of oxidation and dehydration of sulphide sludge, on the four available flights on the old mine works by the river. Increasing reddish colours suggest intense oxidation. Bluish and greenish colour concentrates on hydrated areas (same legend as Figure 3.2). D: Typical terraced dump. E: Detail of mud pond in the dumps (coloured cyan on the maps, copiapite, red circles). H: Slopes on the dumps by the river in 2009, with bursts of greenish melanterite among oxidized coatings on the slopes.

Figura 3.5. Escombrera a orillas del río. A, B y C: Mapas elaborados con datos Hymap de minerales producto de oxidación y deshidratación de lodos de sulfuros, en los tres vuelos disponibles. El predominio de colores rojizos indica oxidación intensa. Los colores azulados y verdosos se concentran en zonas con sulfatos hidratados. D: Escombrera con geomorfología típica en terrazas. E: Detalle de balsa de lodos en las escombreras (cartografiada en añil en los mapas, copiapita, círculos rojos). $H$ :

Taludes en las escombreras a orillas del río en 2009, con afloramientos de 
melanterita verdosa en grietas de las costras predominantemente oxidadas en los taludes.

The eastern wing of the rock pile is more hematitic in 2009 than in 2008, suggesting more intense oxidation (Figure $3.5 \mathrm{C}$, cyan circles). The same dominantly copiapitic hydrated minerals cover the bottom, at the foot of the slopes in the main dump. The western rock pile displays dominant copiapite over formerly schwertmannite slopes (Figure $3.5 \mathrm{C}$, magenta circle). The local mill tailings ponds (Figure $3.5^{\mathrm{B}}$, red circle) keep the expected uniform copiapite coating, but the area is extended to the western slope of the outer pile, which was covered by schwertmannite in 2008. The stream coming from the north-west has a similar mineralogic pattern than in 2008, with the bottom covered by schwermannite (Figure 3.5C, orange circle), and the steeper slopes zones covered by goethite and hematite (Figure $3.5 \mathrm{C}$, green circle), but displaying larger areas in both cases.

The large rock dump displays a constant increasing oxidation on flat tops and slopes from 2005 to 2009, particularly on the eastern wing (Figures $3.5 \mathrm{~A}, 3.5^{\mathrm{B}}$ and Figure $3.5 \mathrm{C}$, white circle). The middle slopes show goethitic surfaces in 2008, which recede in 2009. The bottom of the piles display an opposite trend, to show larger surfaces covered with copiapite from 2005 to 2009 , which is confirmed on the western tailings pond (Figure $3.5 \mathrm{~B}$ and Figure $3.5 \mathrm{C}$, red circle).

The general mineralogical pattern in 2009 shows an increase in oxidation on the flat tops and slopes of the main dumps than in 2008, and an opposite increase of extent of hydratation on the topographically low areas, as well as the less steep and smaller slopes of the western stream. However, the winter and spring of 2008 were dry, compared to a regular winter and spring in 2009 , as far as rainfall is considered. The changes in mineral coatings, in topographically low areas in the rock dumps and minor stream in the summer, are faithful to the rainfall and temperature rate of the previous wet seasons of the year. Minor surfaces along the northern slopes of the main dump also show the same trend, but the large flat hematitic tops do not record such changes in 2008 and 2009. 

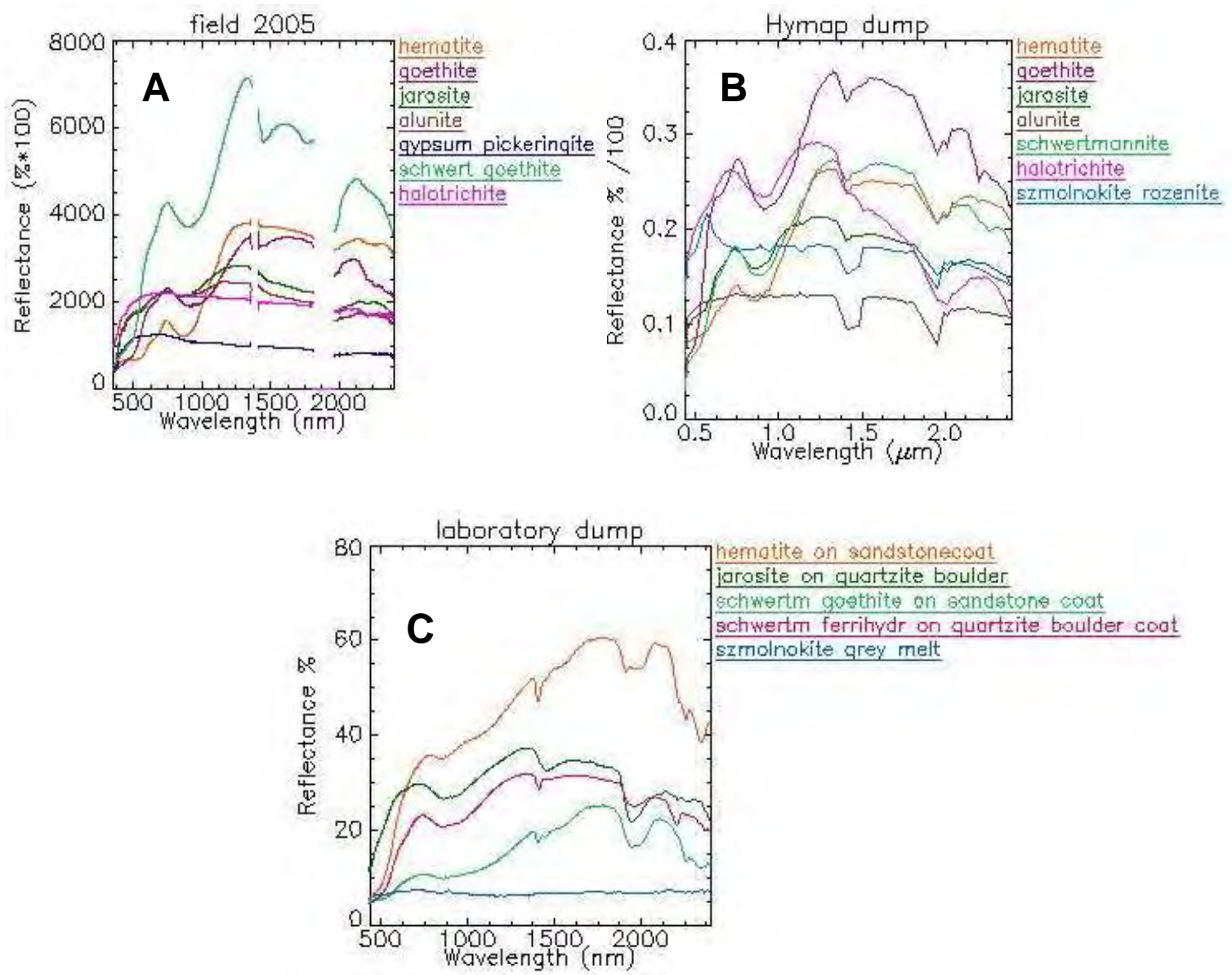

Figure 3.6. Mine dumps by the river. A: Spectra from Hymap areas mapped in June 2005 (Figure 3.5A ), arranged on a precipitation and oxidation sequence. The colour coding follows the trend of the key from figure 3.2, but changes are made for line identification clarity. B: Field spectra measured with an ASD Spectrometer in June 2005. C: Laboratory spectra on samples collected along 2006 on locations guided by Hymap mapping.

Figura 3.6. Escombreras a orillas del río. A: Espectros Hymap de las áreas cartografiadas en Junio de 2005 (Figura 3.5A), ordenados según la secuencia de precipitación a partir de lodos. Los colores asignados se inspiran en la leyenda del mapa de la figura 3.2, con cambios para mejorar la visión sobre fondo blanco. B: Espectros medidos con un espectrómetro ASD en Junio de 2005. C: Espectros de laboratorio en muestras recogidas en 2006 en puntos sugeridos por las cartografias realizadas con imágenes Hymap.

3.5.2.2. Spectral analysis

\subsection{Spectra in the year 2005}

Spectra from data in 2005 (Figures 3.6A, 3.6B and 3.6C) show a variety of oxidized and hydrated compositions. The units diagnosed as hematite, goethite, and jarosite, with reference to the spectral library (Crowley et al., 2003; see also Chapter 1.2 and Chapter 
2.6), dominate the spectra in Hymap imagery, field and laboratory spectra. Occasionally, schwertmannite, halotrichite and szmolnokite occur as spectra with poor spectral features. The hydrated sulphate mineralogical phases develop first from mud, and consequently show poor crystallinity and poor spectral responses. The identification in the reference spectral library is, however, consistent with the location of the crusts on the map built from Hymap and the field sites.

\subsection{Spectra in the year 2008}

Hymap spectra from the 2008 data (Figure 3.7) show predominantly hematitic responses on the flat top of dumps (Riaza and Müller, 2010; Buzzi et al., 2010a). Slopes are diagnosed as schwertmannite, and the flat areas at the bottom of the dumps display hydrated sulphate, which is diagnosed mineralogically as copiapite or jarosite szmolnokite. This is the typical mineralogical display observed from Hymap imagery in any rock dump with a terraced geomorphology in the area.

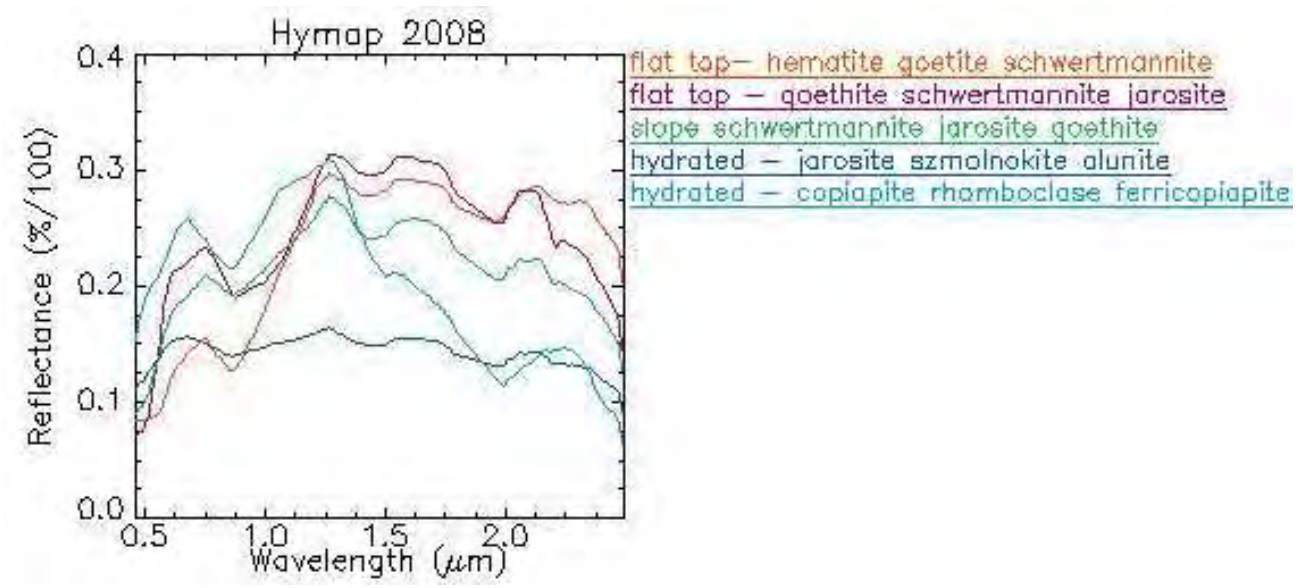

Figure 3.7. Spectra from Hymap areas mapped in August 2008 (Figure 3.5B), arranged on a precipitation and oxidation sequence. The colour coding follows the trend of the key from figure 3.2, but changes are made for line identification clarity.

Figura 3.7. Espectros de imágenes Hymap de las áreas cartografiadas en Agosto de 2008 (Figura 3.5B), según la secuencia de precipitación y oxidación de piritas. Los colores asignados se inspiran en la leyenda del mapa de la figura 3.2, con cambios para mejorar la visión sobre fondo blanco.

\subsection{Spectra in the year 2009}

Spectra from the 2009 Hymap data (Figure 3.8A) display the variety of compositions identified in the map of the dumps (Figure 3.5C). All the identified spectra show the 

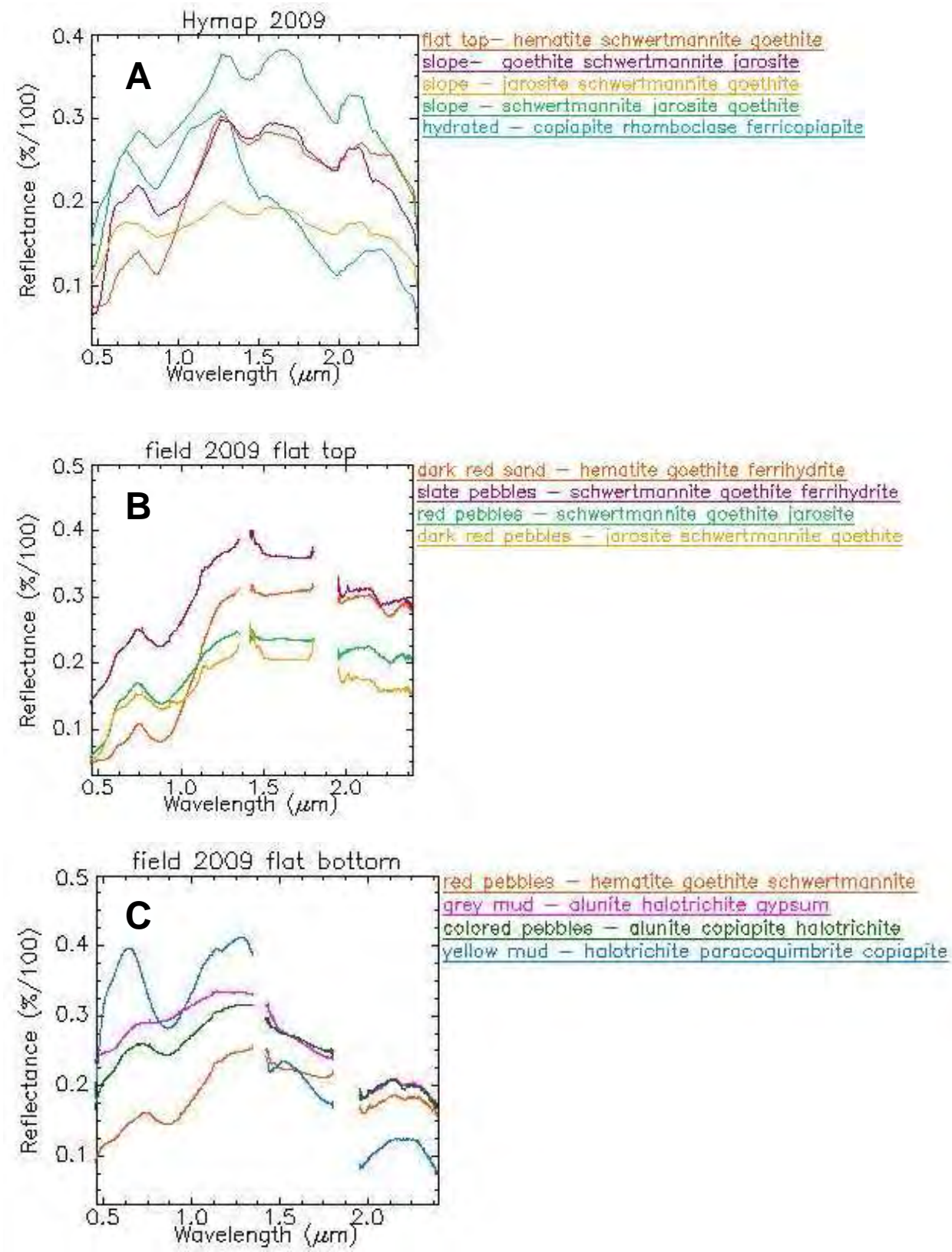

Figure 3.8: Mine dumps by the river. A: Spectra from Hymap areas mapped in August 2009 (Figure 3.5C), arranged on a precipitation and oxidation sequence. The colour coding follows the trend of the key from figure 3.2, but changes are made for line identification clarity. B: Field spectra measured with an ASD Spectrometer in August 2009 in the flat tops of dumps. C: Field spectra measured with an ASD Spectrometer in August 2009 in the bottom of dumps.

Figura 3.8. Escombreras a orillas del río. A: Espectros de imágenes Hymap en las áreas cartografiadas en Agosto de 2009 (Figura 3.5C), según la secuencia de precipitación y oxidación de piritas. Los colores asignados se inspiran en la leyenda del mapa de la figura 3.2, con cambios para mejorar la visión sobre fondo blanco. B: Espectros de campo medidos con un espectrómetro ASD en Agosto de 2009 en las zonas planas al pie de las escombreras. 
typical pattern of oxidized mineralogical phases on the flat tops, schwertmannite on the slopes, and hydrated sulphate on the flat surfaces at the bottom of the dumps.

Field spectra measured on pebbles on the flat tops of dumps (Figure 3.8B) show mainly oxidized minerals, such as hematite, goethite and jarosite. There also are surfaces diagnosed as schwertmannite, particularly if the pebbles are slaty.

Spectra measured on crusts and debris along the bottom of a stream crossing the mine dumps (Figure 3.8C, cyan circle) show a wide variety of elements diagnosed as alunite, a hydrated mineral that occurs in association with the presence of water in sulphide ore mining environments, which is consistent with its presence in an area with a supply of water. Yellow mud measured at the bottom of the slopes bordering the plain of the stream has a diagnosis of strongly hydrated sulphate, such as halotrichite, paracoquimbite and copiapite. Less abundant red pebbles keep their hematite diagnosis.

\subsubsection{THE MILL TAILINGS DAM}

The industrial activities of the ore-processing plant ceased in 2001. Both the pond of ashes and the mill tailings dam were a steady waste storage, but the maintenance of the facilities included water pumping and flowing through the water bodies. Until 2006, the water from the pond of ashes was drained to the mill tailings dam through a channel (Figure 3.9A, red arrow). A mud-cleaning plant at the foot of the wall of the mill tailings dam prevents the contamination of water downstream, and returns processed mud behind the wall to the tailings dam (Figure 3.9B, red arrows). The artificial water supply at known channel outputs influences the pattern of mineral coatings over the surface of the mill tailings, as much as climate parameters and the natural progressive drying up of the mass of mud tailings after the industrial waste supplies stopped.

\subsubsection{Hymap maps}

\subsection{Hymap map in 2005}

In 2005, the minerals coating the surface of the mill tailings are intensely hydrated, dominated by rozenite and szmolnokite (Figure 3.9A, green circle). A fan of uniform pickeringite spreads from the output of the draining channel (Figure 3.9A, blue circle) 

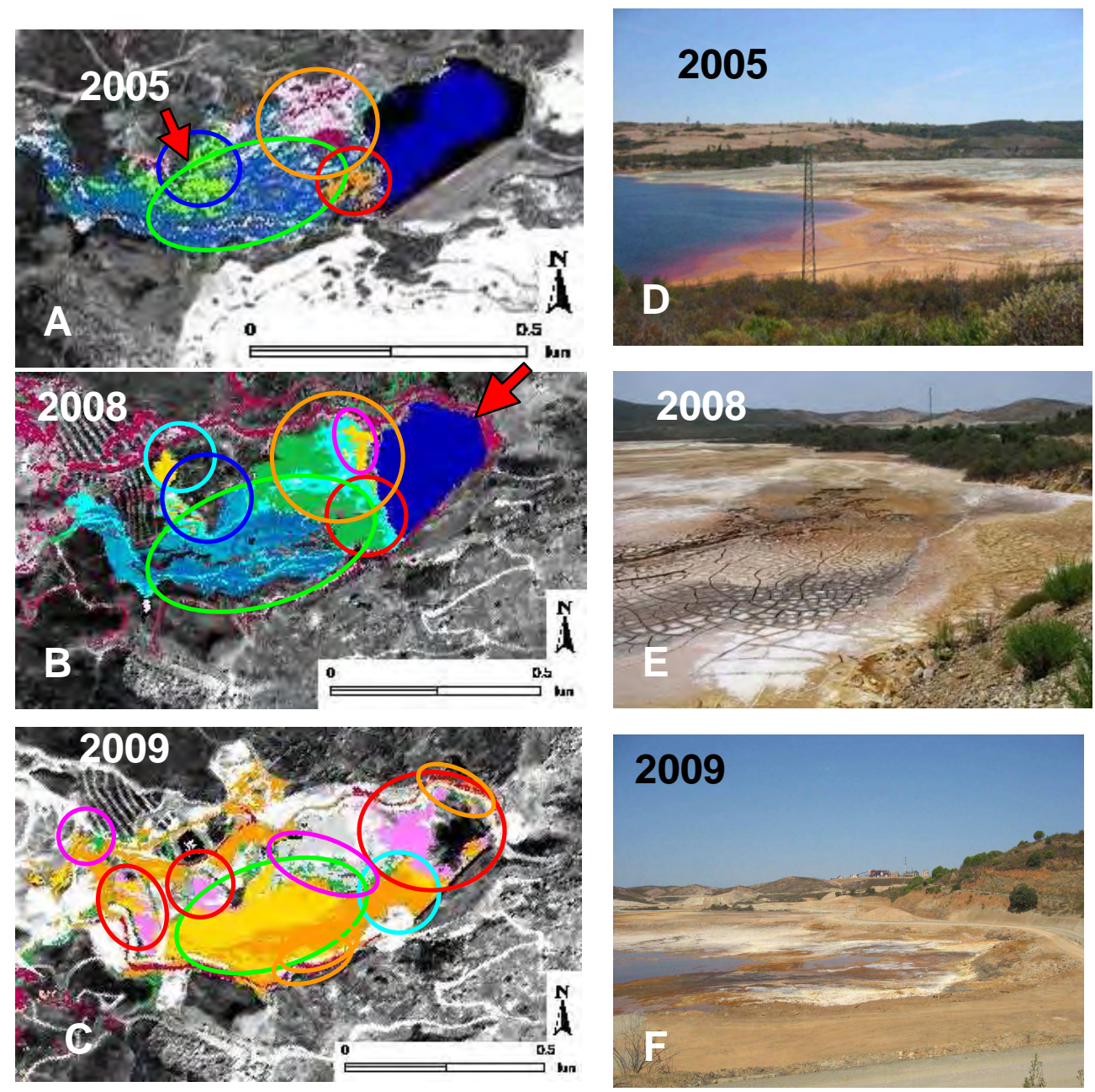

\begin{tabular}{|l}
\hline Hematite \\
Goethite \\
Ferrihydrite \\
Jarosite \\
Alunite \\
Gypsum \\
Fibroferrite \\
Epsomite \\
Schwertmannite \\
Halotrichite \\
Rhomboclase \\
Pickeringite \\
Paracoquimbite \\
Copiapite \\
Ferricopiapite \\
Szmolnokite \\
Rozenite \\
Melanterite
\end{tabular}

$\mathrm{Fe}_{2} \mathrm{O}_{3}$ $\mathrm{FeO}(\mathrm{OH})$

$\mathrm{Fe}^{3+}{ }_{2} \mathrm{O}_{3} \cdot 0.5\left(\mathrm{H}_{2} \mathrm{O}\right)$

$\mathrm{KFe}_{3}\left(\mathrm{SO}_{4}\right)_{2}(\mathrm{OH})_{6}$

$\mathrm{KAl}_{3}\left(\mathrm{SO}_{4}\right)_{2}(\mathrm{OH})_{6}$

$\mathrm{SO}_{4} \mathrm{Ca} .2 \mathrm{H}_{2} \mathrm{O}$

$\mathrm{Fe}^{3+}\left(\mathrm{SO}_{4}\right)(\mathrm{OH}) \cdot 5\left(\mathrm{H}_{2} \mathrm{O}\right)$

$\mathrm{MgSO}_{4} \cdot 7\left(\mathrm{H}_{2} \mathrm{O}\right)$

$\mathrm{Fe}^{3+} 16 \mathrm{O}_{16}(\mathrm{OH})_{12}\left(\mathrm{SO}_{4}\right)_{2}$

$\mathrm{Fe}^{2+} \mathrm{Al}_{2}(\mathrm{SO} 4)_{4} \cdot 22\left(\mathrm{H}_{2} \mathrm{O}\right)$

$\mathrm{HFe}^{3+}\left(\mathrm{SO}_{4}\right)_{2} \cdot 4\left(\mathrm{H}_{2} \mathrm{O}\right)$

$\mathrm{MgAl}_{2}\left(\mathrm{SO}_{4}\right)_{4} \cdot 22\left(\mathrm{H}_{2} \mathrm{O}\right)$

$\mathrm{Fe}^{3+}{ }_{2}\left(\mathrm{SO}_{4}\right)_{3} \cdot 9\left(\mathrm{H}_{2} \mathrm{O}\right)$

$\mathrm{Fe}^{2+} \mathrm{Fe}^{3+}{ }_{4}\left(\mathrm{SO}_{4}\right)_{6}(\mathrm{OH})_{2} \cdot 20\left(\mathrm{H}_{2} \mathrm{O}\right)$

$\mathrm{Fe}^{3+}{ }_{0.6666}{ }^{\mathrm{Fe} 3+}{ }_{4}\left(\mathrm{SO}_{4}\right)_{6}(\mathrm{OH})_{2} \cdot 20\left(\mathrm{H}_{2} \mathrm{O}\right)$

$\mathrm{Fe}\left(\mathrm{SO}_{4}\right) . \mathrm{H}_{2} \mathrm{O}$

$\mathrm{Fe}^{2+}\left(\mathrm{SO}_{4}\right) \cdot 4\left(\mathrm{H}_{2} \mathrm{O}\right)$

$\mathrm{Fe}^{2+}\left(\mathrm{SO}_{4}\right) \cdot 7\left(\mathrm{H}_{2} \mathrm{O}\right)$

Figure 3.9. The mill tailings dam. A, B and C: Maps compiled from Hymap data on the minerals product of oxidation and dehydration of sulphide sludge, on the three available flights on the southern mill tailings dam. Bluish and greenish colours concentrate on comparatively hydrated areas. Orange and dark red colour corresponds to oxidised end members. Dark blue is acid water stored behind the wall of the dam.

Red arrows are locations of mud supply. D, E and F: Panoramic view of the mill tailings dam in the corresponding years 2005, 2008 and 2009.

Figura 3.9. La balsa de lodos. A, B y C: Mapas elaborados con datos Hymap de minerales producto de oxidación y deshidratación de lodos de sulfuros, en los tres 
vuelos disponibles. El predominio de colores rojizos y anaranjados indica oxidación intensa. Los colores azulados y verdosos se concentran en zonas con sulfatos hidratados. El agua almacenada detrás de la pared de la balsa se colorea de azul oscuro. Las flechas rojas indican los puntos de aporte de lodos. D, E y F: Vista panorámica de la balsa de lodos en los años correspondientes a los mapas, 2005, 2008 y 2009.

supplying water from the dam of ashes (Figure 3.9A, red arrow). The mud is comparatively shallower at this point, and the outer coating is comparatively more oxidized than the general mass of mud tailings. In 2005, the dam of ashes is highly oxidized (Figure 3.9A). Oxidized mineralogical phases such as goethite and jarosite are located far from the water supply, close to the border of the water of the pond (Figure 3.9A, red circle), and surrounded by comparatively more hydrated halotrichite (Figure 3.9A, orange circle).

Rainwater and mass movements inside the mill tailings develop a microgeomorphology with rills and minor ridges. Most of the surface of the dam is covered by szmolnokite grooved by channels (Figure 3.9A, green circle), with a bottom of rozenite, a slightly more hydrated mineralogical phase. The topographically lower areas host small patches of copiapite.

\subsection{Hymap map in 2008}

The dam of ashes was cleaned in 2006, and the draining of water to the mill tailings dam stopped. A water cleaning plant at the foot of the wall of the dam prevents the spread of contamination to run-off. In 2008, the only water was supplied by two pipes at both ends of the wall of the mill tailings dam, pumping water from the water cleaning plant at the foot of the wall (Figures 3.9A and 3.9B, red arrows). The area covered by the most hydrated mineralogical phases is strongly dependent on the location of the water supplied by the maintenance of facilities.

The progressive dehydration and oxidation of the secondary minerals of the mill tailings dam, from 2005 to 2008, is evidenced by the increasing extent of oxidized mineralogical phases. 2005 was dryer and warmer than 2008. The effects of the decreasing temperature and less available moisture, in 2005, are visible in the mineralogy of the coatings on the surface of the mill tailings dam.

The surface that, in 2005, was covered by rozenite and szmolnokite (Figure 3.9A, green circle) at the tail of the mill tailings is dominated by melanterite, rozenite and copiapite 
(Figure 3.9B, green circle) in 2008. This surface of hydrated minerals has decreased its extension from 2005, owing to the lack of water supplies from the dam of ashes. Since the mud tailings mass has been moving without mud supplies since 2006, rills and ridges are better developed in the upper surface of coatings over the mud tailings mass in 2008 than in 2005. The pattern of mineralogical phases shows a strong topographical control, with melanterite dominating the western tail, and rozenite drawing the more hydrated rills, while copiapite traces the less humid rills.

The lack of water supply from the ashes dam erases the pickeringite surface visible in 2005 (Figure 3.9B, blue circle), and the replacement by a copiapite and alunite tail in 2008, where there was a water floodgate in 2005 (Figure 3.9A, red arrow). The topographically most elevated area by the former water floodgate is covered by a uniform surface of alunite in 2008 (Figure 3.9B, cyan circle).

The surface located to the north-east of the dam, covered by halotrichite in 2005 , changed its composition and distribution of secondary minerals in 2008 (Figure 3.9B, orange circle). There is a wide uniform surface of schwertmannite in comparatively topographically elevated areas, over a lower copiapitic bottom, drawing a topographic valley that drained to the pond of water behind the wall of the dam. This schwertmannite and copiapite topographically controlled area, in 2008, replaces szmolnonite and halotrichite in 2005, showing an increasing oxidation process.

In the border close to the water there is a stripe of alunite in 2008 (Figure 3.9B, magenta circle). This spatial pattern of schwertmannite and copiapite is extended southwards, replacing a small jarosite area in 2005 (Figures 3.9A and 3.9B, red circle). This jarositic area is the most oxidized spot in 2005, the far end the water supply at the time, and moves in 2008 to the northern border of the water pond, a comparatively topographically high spot with a concentration of increasing oxidation processes.

Stripes of goethite, associated with roads and movement of machinery run all around the mud tailings mud in 2008.

\subsection{Hymap map in 2009}

The recovery of the mill tailings dam began in the autumn of 2008 until 2011. The mill tailings were actively drained and dried during the winter and spring of 2009. In summer 2009 (Figure 3.9C), the surface of the mill tailings dam was dry and accessible on foot, and following the process of consolidation, allowed the operation of machinery. 
The area formerly flooded behind the wall in 2008 is, in 2009, largely covered by halotrichite (Figure 3.9C, red circles). Halotrichite patches occur in other areas at the tail of the mill tailings dam, where mud remains behind walls, which were covered by mud in 2008 (Figure 3.9C, red circles). Drying up by recovery activities, during 2009, caused the generalized oxidation of the mineral coatings to jarosite and alunite (Figure 3.9C, green circle), with schwertmannitic outer fringes (Figure 3.9C, magenta circles), replacing the hydrated szmolnokite, rozenite and melanterite that dominated the surface of the tailings in 2005 and 2008 (Figures 3.9A and 3.9B, green circles). The dominant schwertmannitic area in 2008 (Figure 3.9B, orange circle) is not identified as covered by sulphate in 2009. The intense dehydration by the recovery activities reaches their purpose at this spot in 2009, as far as hyperspectral data can record.

The paths and roads around the mill tailings dam are covered by oxidized mineralogical phases, as in 2008, such as goethite (Figure 3.9C, orange circles), with jarosite contributions in 2009.

\subsubsection{Spectral analysis}

\subsection{Spectra in the year 2005}

Hymap spectra of the different identified units in the mill tailings dam in 2005 (Figure 3.10A) reflect the variety of minerals that cover the mill tailings dam, with the dominant presence of hydrated sulphate mineral phases. Goethite and gypsum occur, preferably along the edges of the mass of tailings, whereas the rest of the surface of mud displays a whitish crust, diagnosed spectrally as alunite, pickeringite, copiapite and rozenite (Crowley et al., 2003).

\subsection{Spectra in the year 2008}

In 2008, the main mineralogies that appear in Hymap data are hydrated (Figure3.10B). The large schwertmannite areas behind the water pond are followed by more oxidized mineralogical phases, such as goethite and jarosite, pointing to the increasing oxidation process which is already taking place. The spectra from the hydrated sulphate, rozenite and melanterite show enhanced absorption features, indicating a better developed crystallinity than in 2005. Since the mud supplied to the dam is decreasing, the surface has time for the minerals to develop better mineralogical structures. 

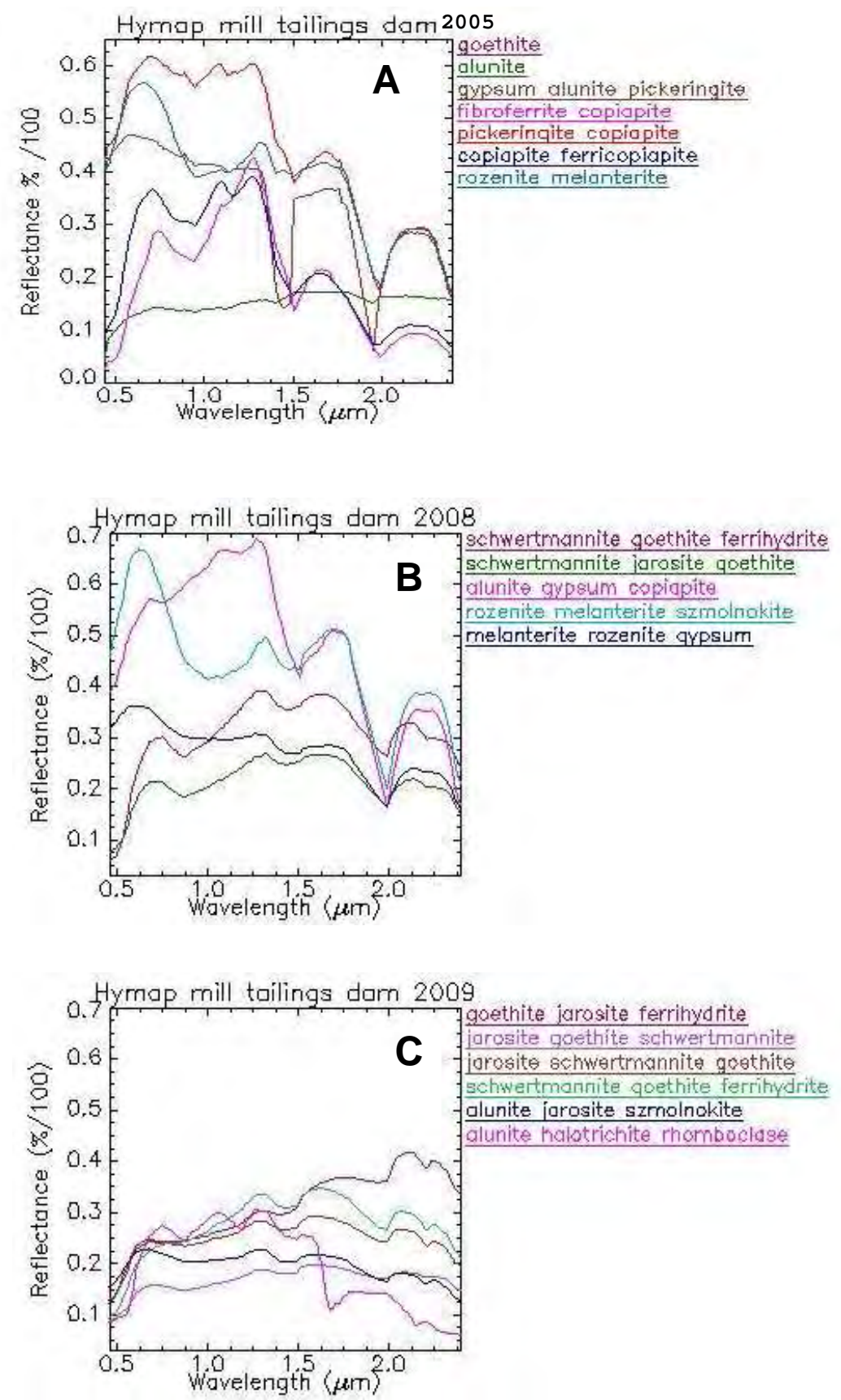

Figure 3.10. The mill tailings dam. A: Spectra from Hymap areas mapped in June 2005. B: Spectra from Hymap areas mapped in August 2008. C: Spectra from Hymap areas mapped in and August 2009. Spectra are arranged on a precipitation and oxidation sequence. The colour coding follows the trend of the key from figure 3.2, but changes are made for line identification clarity.

Figura 3.10. La balsa de lodos. A: Espectros de imágenes Hymap en las áreas cartografiadas en Junio de 2005. B: Espectros de imágenes Hymap en las áreas cartografiadas en Agosto de 2008. C: Espectros de imágenes Hymap en las áreas cartografiadas en Agosto de 2009. Los espectros se ordenan según la secuencia de minerales de precipitación y oxidación de piritas. Los colores asignados se inspiran en la leyenda del mapa de la figura 3.2, con cambios para mejorar la visión sobre fondo blanco. 


\subsection{Spectra in the year 2009}

Hymap spectra of the identified units in 2009 (Figure 3.10C) show the presence mainly of oxidized minerals, since the recovery process has already begun. The most oxidized minerals that appear are goethite and jarosite. The surrounding channels around the dam, built to prevent water from reaching the former surface of mill tailings, are also diagnosed as goethite as first choice.

The hydrated sulphate units are diagnosed as alunite and schwertmannite as first choice. But the second diagnosed minerals are oxidized mineralogical phases (jarosite and goethite), indicating a strongly progressing oxidation even at the most hydrated ends.

Spectra taken with the ASD spectrometer, over different dusty surfaces of the mill tailings dam, show a generalized presence of alunite. Oxidized minerals such as jarosite have been located covering dun gravels, while hydrated compositions, such as schwertmannite, have been identified as associated with mudcracks, which require the presence of water for their development.

\subsubsection{THE ORE-PROCESSING PLANT AND NEIGHBOURHOOD}

The ore-processing plant stopped its industrial activity in 2001. All buildings and waste ponds around were abandoned to any use until 2006, when the recovery of the nearby dam of ashes began. No activity has taken place within the buildings of the plant, but some influence from the movement of machinery can be expected since 2006.

\subsubsection{Hymap maps}

\subsection{Hymap map in 2005}

In 2005, the processing plant is covered by hydrated sulphate, such as paracoquimbite and pickeringite (Figure 3.11A, red circle), covering the dumps around the buildings and in small ponds (Figure 3.11A, cyan circle) storing mill waste. Spots of oxidized iron sulphate, as jarosite, and hydroxides, as goethite (Figure 3.11A, blue circle), cover the outer areas of the facilities, away from the intense influence of the hydrated waste from the former ore-processing activities. 

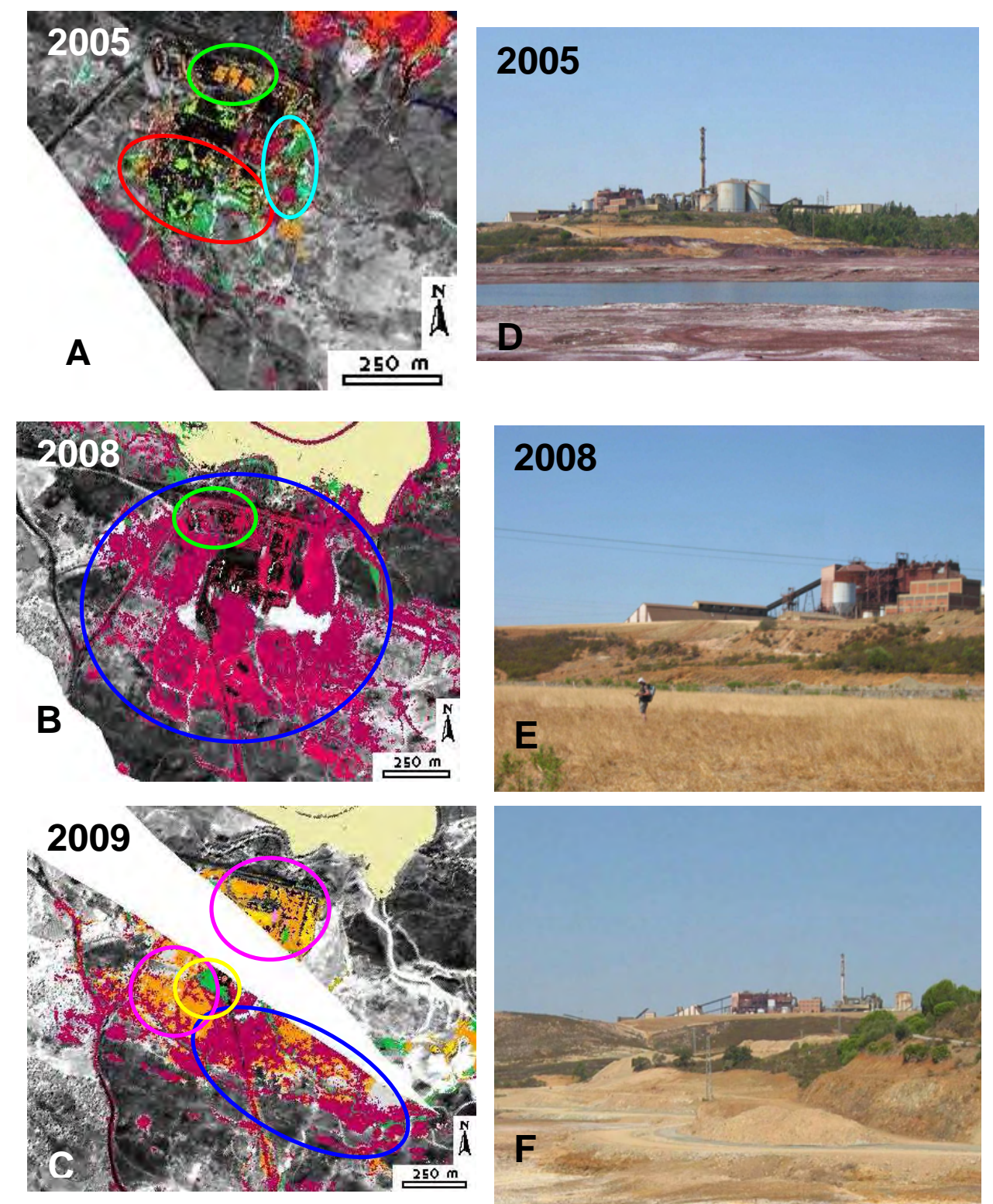

Figure 3.11. The ore processing plant and neighbourhood. A, B and C: Maps compiled from Hymap data on the minerals product of oxidation and dehydration of products of iron sulphide weathering, on the three available flights. Bluish and greenish colours indicate hydrated sulphate. D, E and F: Panoramic view of the ore processing plant in the years 2005, 2008 and 2009.

Figura 3.11. La planta de tratamiento de menas y alrededores. A, B y C: Mapas elaborados con datos Hymap de minerales producto de oxidación y deshidratación de lodos de sulfuros, en los tres vuelos disponibles. Los colores azulados y verdosos se concentran en zonas con sulfatos hidratados. D, E y F: Vista panorámica de la planta de tratamiento de menas en los años 2005, 2008 y 2009. 


\subsection{Hymap map in 2008}

The Hymap 2008 flight shows the ashes dam completely recovered and covered by dry grass, its surroundings clean from any pyrite weathering product, which have been cleaned mechanically over the dumps, both around the dam of ashes and the oreprocessing plant (Figure 3.11B). The ore-processing plant and its neighbourhood are intensely oxidized by movement of machinery, the cleaning of small mud ponds, and the cleaning and smoothing of slopes on the dumps around the plant and the dam of ashes.

There is a generalized oxidation evidenced by the covering, by goethite and ferrihydrite (Figure $3.11 \mathrm{~B}$, blue circle), of the entire area around the processing plant. Small dams with hydrated minerals have been also cleaned (Figure 3.11B, cyan circle).

\subsection{Hymap map in 2009}

The dismantling of buildings and machinery began during autumn 2008, and progressed through the winter and spring of 2009. In the summer of 2009 (Figure 3.11C), the movement of machinery and the removal of parts from the processing plant was still active.

There are surfaces of the buildings in the plant covered by jarosite, alunite and some schwertmannite (Figure 3.11C, magenta circle), while the neighbourhood of the processing plant is covered by goethite over the already cleaned dumps and rock outcrops (Figure 3.11C, blue circle). The intensity of oxidation receding in 2009 from 2008, both around the ore-processing plant and the roads around the mill tailings plant, may be explained by the transport of different materials used during the recovery process.

\subsection{DISCUSSION}

Although mineral identification of hyperspectral pixels necessarily involves reducing high-dimensional spectral data to one-compositional class, in reality, pixels are rarely pure and their spectral signatures often reflect heterogeneous forms of mixing. Both field and laboratory spectral experience, from samples collected at the mine site, show that most spectral features are mixed responses from the selected minerals which are likely to occur. Only very extended and spatially well-developed pans of intensely oxidized pyrite mud show clearly identifiable spectral signatures, compared to the 
archive spectral libraries. The oxidation of pyrite is a progressive and heterogeneous process concerning mineralogical phases and spatial cover, as well as grain size or minor shade effects associated with small-scale geomorphology. The areas identified on the imagery as a single or double mineral presence should be interpreted as indicators of a mineralogically dominant trend, displayed by Hymap imagery with a $5 \mathrm{~m}$ spatial resolution. Field pictures illustrate the small-scale heterogeneity of the mineralogical and geomorphologic variety on the map, far smaller than the $5 \mathrm{~m}^{2}$ area.

Prior work monitored mineralogical changes on mine waste at this mine site, considering geomorphological influences under seasonal climate changes (Riaza and Müller, 2010). Hymap flights from 1999 to 2005 were used to support observations. This work, in contrast, concentrates on the mineralogical effects induced at the mine site by an intense recovery activity that has already been running for six years.

The complete recovery of the dam of ashes opens up the monitoring of possible changes by the long-term spectral study of vegetation growing over the recovered premises.

The mine dumps by the river remained undisturbed by human activity during the whole 2005-2009 period. Prior work on mine waste piles concluded that they are more resistant to weathering because they are completely dominated by coarse particles (Riaza and Müller, 2010). They respond to changes in temperature and precipitation more slowly than mud tailings, thus acting as more reliable traces of seasonal or longer periods of climate variability.

The mineralogy of the coatings over mine dumps is strongly controlled by their terraced geomorphology (Riaza and Müller, 2010; Riaza et al., 2011a). From 2005 to 2009, the flat tops of the terraced rock dumps showed uniform hematitic coatings with fringes of goethite. Flat surfaces with less homogeneous geomorphology displayed more variable mineralogical trends. Small slopes and topographically low areas are more sensitive to showing mineralogical changes, responding to short-term climate variability.

Both the progressing wok on the mill tailings dam and the ore-processing plant illustrate mineralogical trends associated with changes in the activities of recovery. The active cleaning of crusts over dumps is translated spectrally to an intense oxidation, evident in 2008, around the ore-processing plant, which recedes partly with the removal of buildings and machinery in 2009. 
On the mill tailings dam, the changes in the locations of water supply are critical to the pattern of mineralogical coatings on the upper crust of the mud mass. The depth of mud is also partly responsible for the mineralogical phases on the surface. The lack of water and mud supplies lets the mud mass movement display a minor geomorphology on the surface, which is translated directly to mineralogical changes obvious in 2009.

\subsection{CONCLUSIONS}

Industrial activity stopped at the mine of Sotiel-Almagrera (Huelva) in 2000. The recovery by the regional government begun in 2006, with the closure of the ashes dam, which was still ongoing in 2011. The 2005 Hymap flight pictures the state of the facilities before any recovery activity, with an intensely oxidized ashes dam, a comparatively hydrated mud tailings dam, and oxidized buildings of the ore-processing plant, surrounded by hydrated small mud ponds.

The 2008 Hymap flight shows the ashes dam covered by dry grass, completely recovered, and surroundings clean from any pyrite weathering product, which have been cleaned mechanically over the dumps. The ore-processing plant and neighbourhood are intensely oxidized by the movement of machinery and cleaning of small mud ponds. The mud tailings dam is still dominantly hydrated, although some progress in oxidation can be seen at the mud supply locations, which have ceased operation since the closure of the ashes dam.

In 2009, the mud from the mud tailings dam is removed, and the state of oxidation is intermediate, like the ore-processing plant and its surroundings, where buildings and machinery are already in the process of being dismantled. The movement of machinery throughout the facilities makes the oxidation state of the whole surface appear uniform on the imagery.

The microgeomorphology controls the mineralogical coatings on the surface of mill tailings, when there are no artificial supplies of water or mud. The same is true on rock piles of larger dimensions, where minor slopes and topographically low areas are more sensitive to mineralogical changes associated with climate variability.

This proves that hyperspectral imagery is an invaluable witness of changes experienced by abandoned mine sites, whether only under the influence of climate and the availability of environmental humidity, or intense human activity. 


\section{CHAPTER 4}

\section{MAPING IRON SULPHIDE MINE SITE ON WASTE AND WATER USING AIRBORNE HYMAP AND SPACEBORNE HYPERION HYPERSPECTRAL DATA (LAS HERRERÍAS, HUELVA, SPAIN)}

\subsection{INTRODUCTION}

The Pyrite Belt at the foot of the northern Sierra de Aracena, consists of a thick sequence of vulcanoclastic sediments with interstratified quartzite, sandstone and slate, where igneous rocks outcrop. The landscape is a smooth ridge-valley alternation, with an average elevation difference of $100 \mathrm{~m}$.

Rapid oxidation of sulphides on mine waste produces iron-bearing sulphate and other compounds as secondary minerals (Nordstrom and Alpers, 1999) following a wellknown mineralogical sequence (Buurman, 1975) established in the laboratory (listed in Figure 4.5). Temperature and humidity control evaporation. In regions with a semi-arid climate, where the water table is low and there are annual rainy and dry seasons, the growth of sulphate salts reaches a maximum at the end of the dry season. Thus, the mineralogy of the precipitated salts is a record of available humidity and temperature throughout the year (Seal and Hammarstrom, 2003).

Climate is the controlling factor in the growth and solution of salts on mine waste from pyrite and other metallic sulphides. Most of the previous work on mine waste mapping using hyperspectral data focused on environmental evidence for predicting metal contamination concentration and acid drainage, both on surface water and groundwater (Swayze et al., 1996, 1998, 2000).

Sulphate salt products of pyrite oxidation are highly ephemeral, and washed by seasonally controlled storms. Rain and evaporation rates in areas with a semi-arid climate are restricted by season on a yearly basis. Efflorescences disappear by washing during the sudden and heavy autumn rains, but not during the light summer rains. They precipitate again during the dry season in the following year in a well-known mineral sequence related to their dehydration state (Buurman, 1975). This seasonally 
controlled mineral dehydration process enables the mine waste system to be considered a rapidly changing geological environment responding to climate parameters.

If the procedure can be properly monitored and automated, hyperspectral airborne imagery and analysis is the only tool to register such parameters on a spatial land pattern.

The mine site of Las Herrerías (Pyrite Belt, SW Spain), which mined complex iron sulphide, stopped operating during the eighties. Ore extraction took place through two open pits, now flooded with water (Figure 4.1). Dumps, ponds and water reservoirs have not received industrial supplies for more than twenty years. The two main open pits extracted different metals: the so-called "pyrite" open pit mined mainly iron sulphide, and the "copper" open pit mined sulphide with abundant copper. The water from the copper open pit drains to a series of three lixiviating ponds, sequentially washing the metal contents. The remaining mill tailing ponds are now dry.

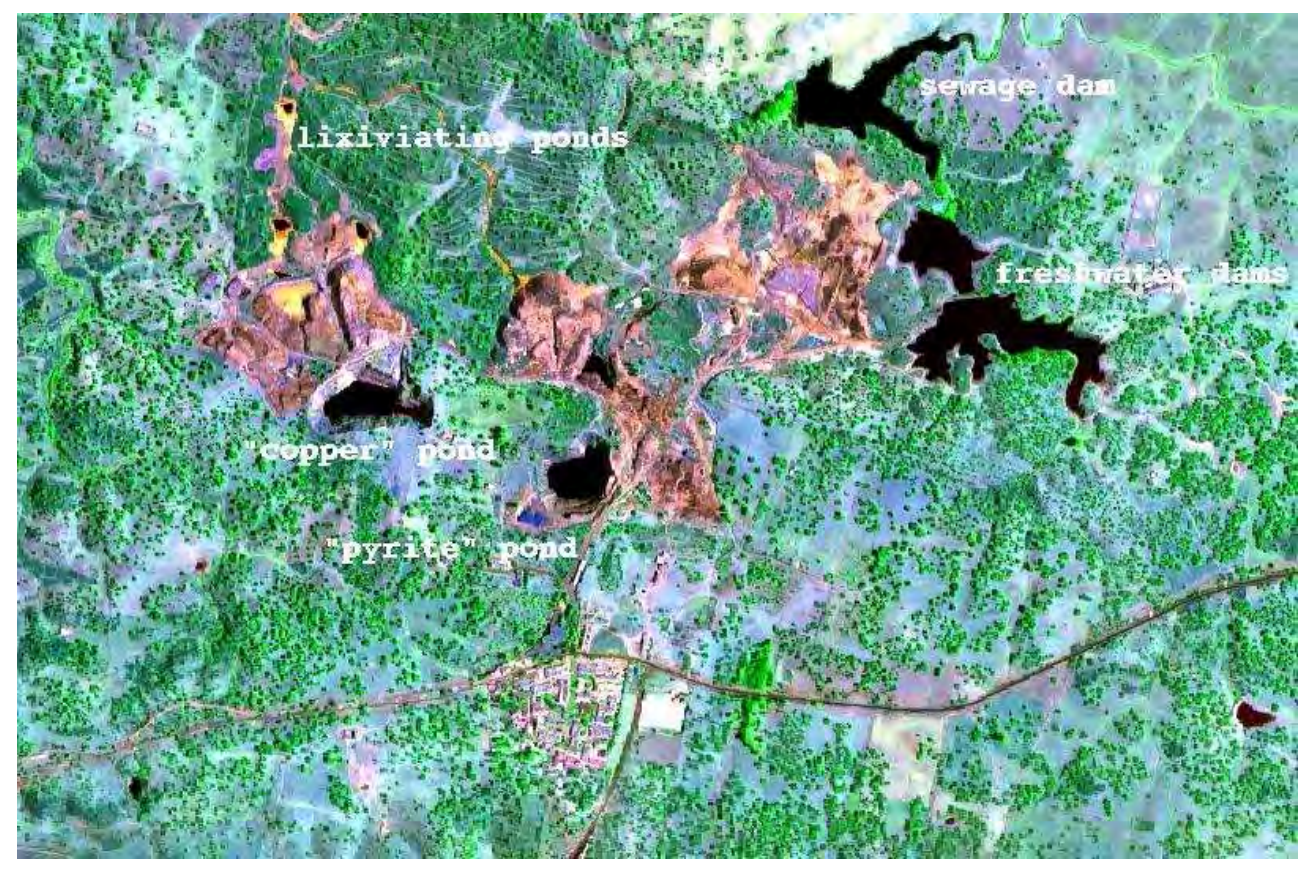

Figure 4.1. False Colour Composite with Hymap channels 11 (o.6029 $\mu \mathrm{m}), 35$ (0.9394 $\mu \mathrm{m})$ and $109(2.2103 \mu \mathrm{m})$ of the Las Herrerías mine site (Pyrite Belt, Huelva, Spain), and identification of water bodies according to the traditional mine operation.

Figura 4.1. Composición en Falso Color con los canales Hymap 11 (o.6o29 $\mu \mathrm{m}$ ), 35 (0.9394 $\mu \mathrm{m})$ y $109(2.2103 \mu \mathrm{m})$ en la mina de Las Herrerías (Faja Pirítica Ibérica, Huelva, España). 
Three water dams, storing freshwater which supplied water for the mine operations, are located to the east of the mine site. Today, two of them supply water to the nearby towns and the third collects the towns' sewage.

Previous work has emphasized the study of the spectral changes of pyrite weathering products related to short-term climate variability by the mapping of mine waste (Riaza et al., 2010a, 2012b, 2011a, 2011b) and precipitates from acid water on drainages (Riaza et al., 2012a) from $4 \mathrm{~m}$ resolution Hymap data, and laboratory spectra. A panoramic view of the weathering state of mine sites and drainages over the whole Pyrite Belt can only be achieved with a satellite sensor such as Hyperion, with a $30 \mathrm{~m}$ spatial resolution, far lower than Hymap. This work describes the challenges and limitations of low spatial resolution spectral mapping on the contamination generated by abandoned mines on the Iberian Pyrite Belt, aiming to develop parameters for a routine monitoring of contaminants using hyperspectral data.

\subsection{SPECTRAL FEATURES OF PYRITE MINE WASTE, ACID MINE DRAINAGES AND MINE WASTE PONDS}

The high spectral resolution of airborne and satellite spectrometers has enlarged the mapping capabilities of remote sensing data, developing widely with the use of AVIRIS data which has operated since 1987. Advances in data calibration and the development of algorithms able to extract information from a large number of spatial spectral data based on field spectra, encouraged the development of applications for environmental issues. Early focus on mine wastes through the study of secondary minerals began, concentrating initially on iron-bearing oxides and hydroxides (Farrand and Harsanyi, 1995). It soon expanded to secondary minerals related to mine waste weathering (Anderson and Robbins, 1998; Clark et al., 1998; Swayze et al., 1996; Levesque, 1997). Since they are highly mobile in the environment through solution in drainage water and recurrent re-precipitation under changing climatic conditions and complex geochemical patterns, minerals generating acid environments, favouring the concentration of heavy metals in water, attracted the attention of the geological scientific community,. The spectral behaviour of pyrites and sulphates derived by oxidation and their solution properties was explored, and patterns of precipitation established and traced using remote sensing hyperspectral data (Swayze et al., 1998; 2000). The development of spectral libraries from field sites has favoured the nearly automatic mapping of ephemeral mineral features related to acid mine drainage (Ong 
et al., 2002; Montero et al., 2002; Ong et al., 2003; Mars and Crowley, 2003; Sares et al., 2003).

Previous work on mine dumps in the area of study has focused on the mapping of pyrite weathering products (Velasco et al., 2005; Riaza et al., 2007, 2010a, 2010b).

Inland, estuarine and coastal water are the subject of a number of studies using hyperspectral sensors aiming to estimate water quality parameters, such as coloured dissolved organic matter, chlorophyll and suspended matter (Karaska et al., 2004; Brando and Dekker, 2003; Dekker and Hoogenbom, 1996).

The geochemistry of contamination in water by mining activities in the Pyrite Belt is monitored closely by local hydrogeologists, both on inland and estuarine and coastal waters (Nieto et al., 2007; Cánovas et al., 2007; Sarmiento et al., 2006, 2009; Olias et al., 2006; Sanchez España et al., 2005).

The spectral properties of acid water do not attract the same attention as the precipitates that it generates. However, acid water has a distinct spectral response that can suggest the intensity of acidity both in stream water (Riaza et al., 2012a, 2012b) and in mine-site ponds. This work explores the spectral response of water from the mine-site water bodies and the relationship with water acidity expressed by $\mathrm{pH}$ values.

\subsection{DATASET}

\subsubsection{IMAGERY}

Hyperion data were acquired over the mine site of Herrerías (western Pyrite Belt) on the $10^{\text {th }}$ September 2006 and the $24^{\text {th }}$ August 2007. Hymap data were acquired in a flight on the $13^{\text {th }}$ August 2009. Field spectra on mine dumps and calibration targets were measured during the flight.

Hymap and Hyperion pre-processing are described in chapter 2.3 and 2.4.

\subsubsection{GEOLOGICAL GROUND AND LABORATORY SURVEY}

Twenty representative samples of rock and loose material have been collected from mine dumps, and twenty water samples from the mine site of Las Herrerías. The sampling procedures benefited from previous experience on similar mine waste in the area. Rocks and soils are mineralogically analysed, and selected samples undergo 
powder X-ray diffraction analysis focusing on iron sulphate, oxides and salts, such as phosphate, chloride and fluoride, introduced by industrial mine operations.

Several physicochemical parameters of water samples were measured in the laboratory with procedures described in Chapter 1.7.4.1.
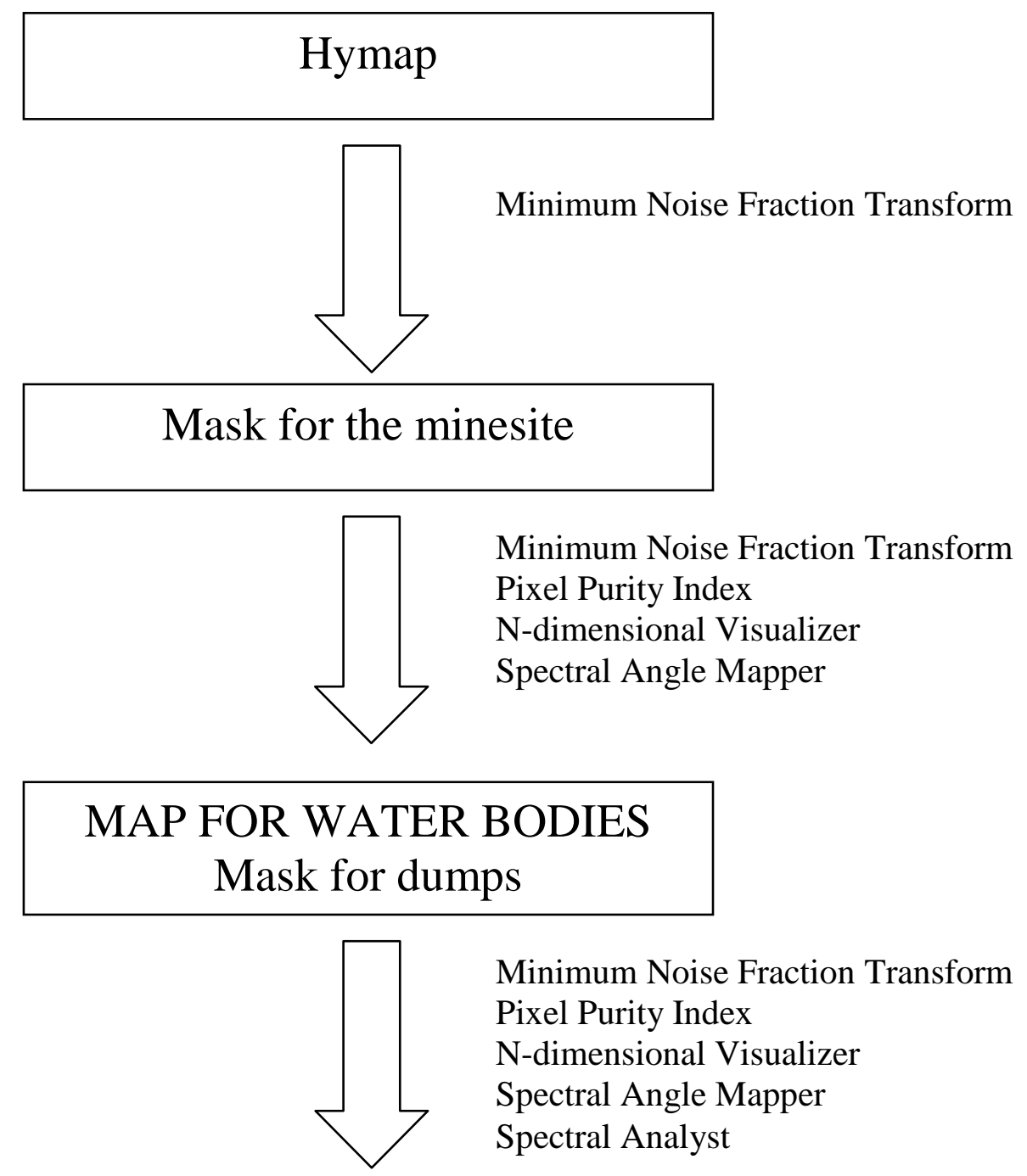

\section{MAP FOR DUMPS}

Figure 4.2. Sequence of hyperspectral image processing algorithms to build maps for water and dumps on the mine site from Hymap data.

Figura 4.2. Secuencia de algoritmos de tratamiento hiperespectral de imágenes para elaborar mapas cuerpos de agua y escombreras en la mina de las Herrerías con imágenes Hymap. 


\subsection{MAPPING THROUGH IMAGE PROCESSING}

The production of maps summarizing the oxidation state of pyrite mine waste, river sediments and water was achieved by ENVI software (RSI 2000). The main steps followed to produce a map on a mine waste are described in chapter 2.7. The procedures below give details on the mine site of Herrerías, with special concern on water mapping from solid mine waste.

\subsubsection{HYMAP}

By running only Minimum Transform Fraction on a sub-scene covering the surroundings of the mine site (Figure 4.2), the areas disturbed by mining are clearly identified. The same sequence of algorithms identifies six spectrally different mineral mixtures developed over the dumps. Translating the stage of the mineralogical pyrite oxidation sequence (Buurman, 1975), a map is built repeating the same procedure used to map water. The hydrated mineralogical assemblages occur on small areas, difficult to detect in the sequence of image processing. Therefore, the sequence of algorithms is performed on the unclassified areas on the first produced map of dumps in order to add the hydrated mineralogical endmembers to a final map.

The area covered by water was isolated from channel $34(0.9239 \mu \mathrm{m})$. The sequence of hyperspectral image processing algorithms, beginning with Minimum Noise Fraction Transforms following the Pixel Purity Index and the N-dimensional visualizer (RSI 2000), performed on the water mask results in a spectral library for six spectrally different water bodies. A map is built using Spectral Angle Mapper with those endmembers.

The spectra from the endmembers identified on the map, resulting from the $\mathrm{N}$ dimensional visualizer, are mineralogically identified with the Spectral Analyst (RSI, 2000) using a reference spectral library elaborated on the products of the weathering of iron sulphide (Crowley et al., 2003). The legend of the map of mine dumps collects this mineralogical identification.

\subsubsection{HYPERION}

Hyperion data were thematically explored before any noise or atmospheric correction. Initial land use exploration using direct spectral $\mathrm{Z}$ profiles suggested a sub-scene around the mine site to progress image processing (Figure 4.3). The mine site is an 
anomalous spectral feature in the flight line. Preliminary image processing exploring the spectral variability, after removing vegetation and open land used for agriculture, easily produces an initial mask to deepen the spectral mapping within the mine site.

\section{Hyperion 144 channels}
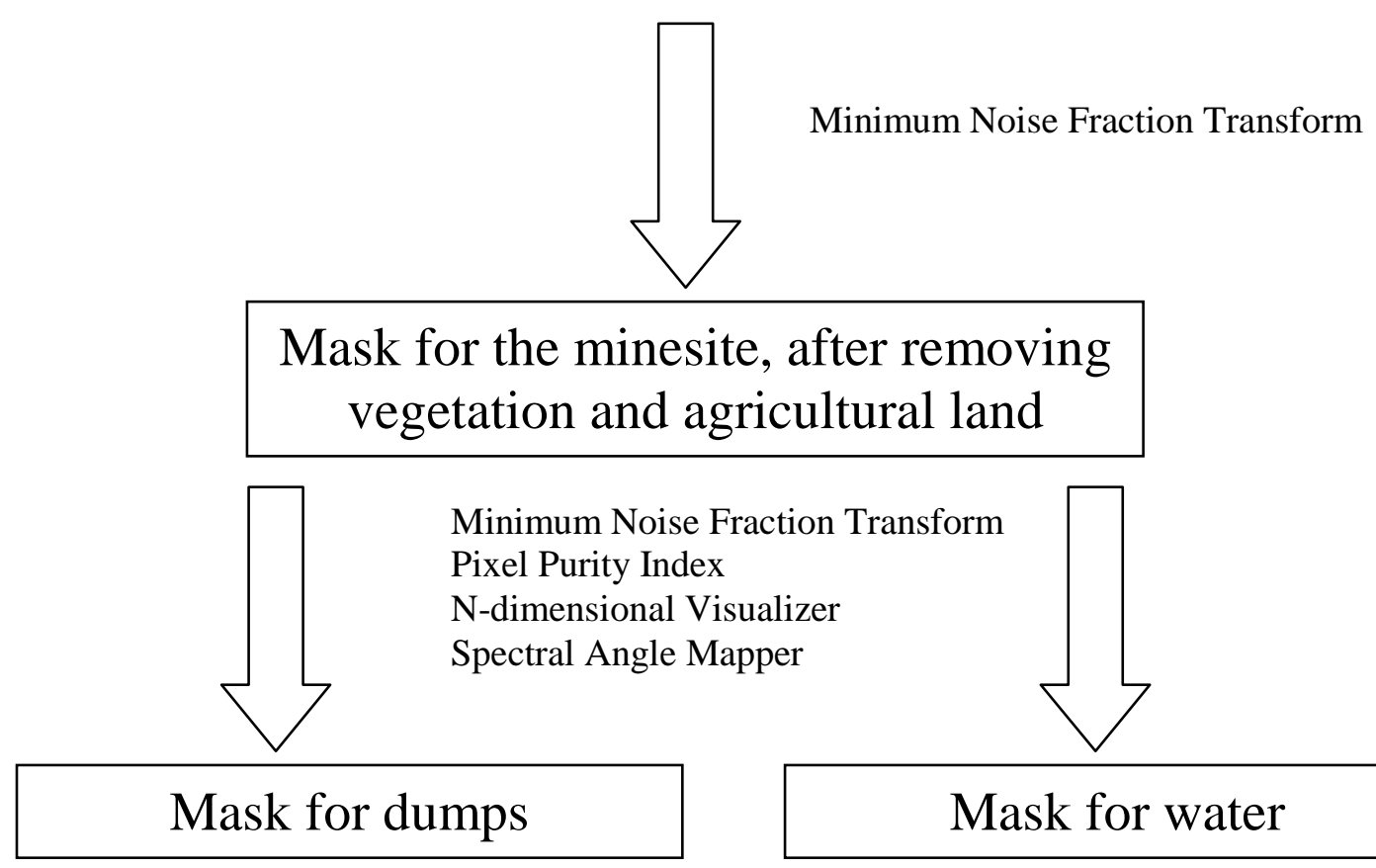

Minimum Noise Fraction Transform

Pixel Purity Index

$\mathrm{N}$-dimensional Visualizer

Spectral Angle Mapper

Spectral Analyst

\section{MAP FOR DUMPS}

\section{MAP FOR WATER}

Figure 4.3. Sequence of hyperspectral image processing algorithms to produce maps for dumps and water on the mine site from Hyperion 144 channels after atmospheric correction through the empirical line model.

Figura 4.3. Secuencia de algoritmos de tratamiento hiperespectral de imágenes para elaborar mapas cuerpos de agua y escombreras en la mina de las Herrerías con imágenes Hyperion de satélite con 144 canales después de correcciones de ruido, y atmosféricas por el método de la corrección empírica. 
After the atmospheric correction, the sequence of hyperspectral image processing algorithms, beginning with Minimum Noise Fraction Transforms, following Pixel Purity Index and N-dimensional visualizer (RSI, 2000), is applied (Figure 4.3), and separate masks are produced for land and water within the mine site.

The same sequence of algorithms within the mask made for land produces a map containing four different mineralogical coatings over the mine dumps. The same image processing sequence of algorithms is applied to the area of the mask for water, which results in a map identifying spectral differences between all the water bodies in and around the mine dumps. Significant spectral differences over mine dumps only arise in operating with regions of interest with a reduced number of points on the Pixel Purity Index file. The spatial resolution of $30 \mathrm{~m}$ of Hyperion provides a total mappable area of 850 digital numbers. Mapping units with this reduced sample is challenging, and the resulting maps are necessarily noisy. The spectral interpretation of the Hyperion data takes the maps produced from Hymap as a reference for a geological evaluation.

A similar procedure is applied to the Hyperion data from 2007, resulting in a map gathering similar mineralogical cover over the mine dumps to that of 2006. No attempt has been made to identify mineralogically the spectra of the geological units identified on the maps using the reference spectral library for the oxidation products of iron sulphide (Crowley et al., 2003). The data are too noisy and the atmospheric corrections too imperfect to produce reliable spectra for a mineral diagnosis.

\subsection{SPECTRAL INTERPRETATION}

\subsubsection{LAND}

\subsubsection{Hymap}

The map compiled with Hymap data (Figure 4.4A) displays three main dumps with the typical shape of a hill with a flattened top and steep slopes on a terraced landscape (Figure 4.4B). Water can occasionally develop shallow layers on flattened surfaces within the dumps.

On the mine site, hematite covers restricted flat surfaces, close to old buildings. The hematite surfaces often display bordering rims of iron hydroxide as goethite (Figure 4.4A). Jarosite coatings cover most of the less steep surfaces with the exception of hematite. Slopes show the growth of schwertmannite. Alunite and fibroferrite occur 
along the bottom of streams draining from the dumps. Hydrated sulphates, such as copiapite, surround the small lixiviating ponds. The areas with transit around the lixiviating ponds display mainly goethite with minor hematite covers. This strong control of geomorphology on the dominant mineralogy of the dump coatings follows the pattern described at the Sotiel mine site (Riaza et al., 2007; 2010a).

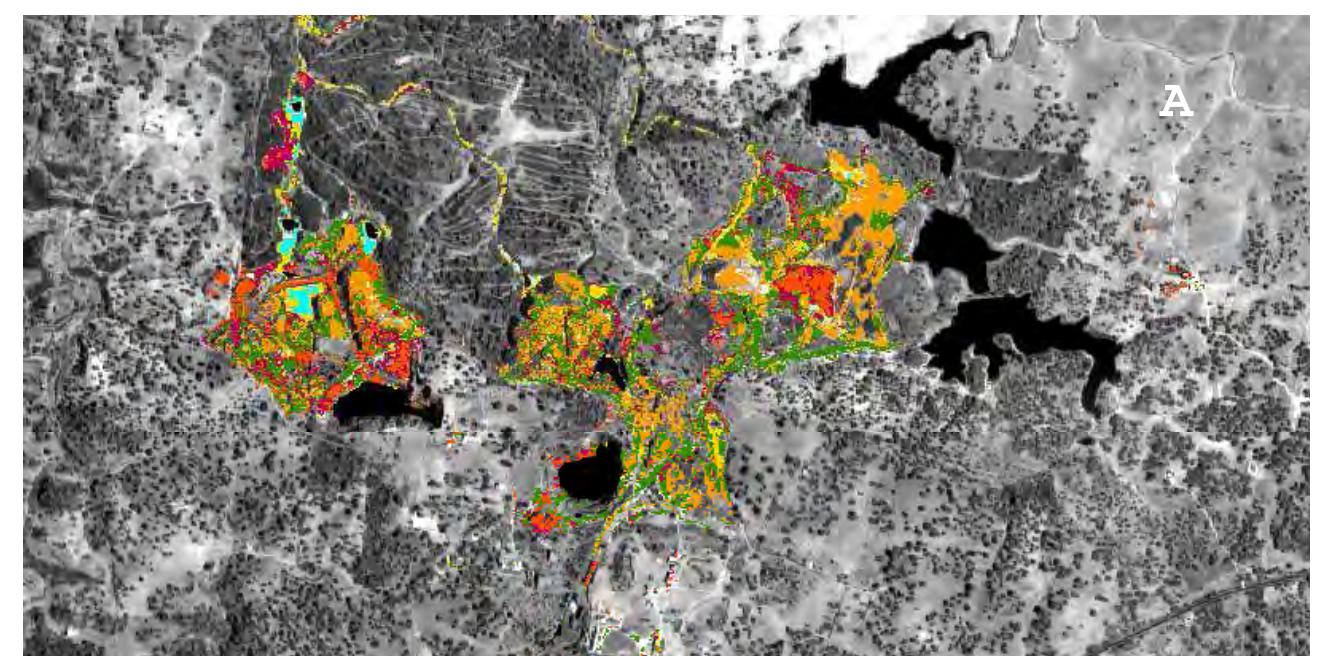

\begin{tabular}{|c|c|}
\hline Hematite & $\mathrm{Fe}_{2} \mathrm{O}_{3}$ \\
\hline Goethite & $\mathrm{FeO}(\mathrm{OH})$ \\
\hline \multicolumn{2}{|c|}{ Ferrihydrite $\mathrm{Fe}^{3+}{ }_{2} \mathrm{O}_{3} \cdot 0.5\left(\mathrm{H}_{2} \mathrm{O}\right)$} \\
\hline Jarosite & $\left(\mathrm{SO}_{4}\right)_{2} \mathrm{KFe}_{3}(\mathrm{OH})_{6}$ \\
\hline Alunite & $\mathrm{KAl}_{3}\left(\mathrm{SO}_{4}\right)_{2}(\mathrm{OH})_{6}$ \\
\hline Gypsum & $\mathrm{SO}_{4} \mathrm{Ca} \cdot 2 \mathrm{H}_{2} \mathrm{O}$ \\
\hline Fibroferrite & $\mathrm{Fe}^{3+}\left(\mathrm{SO}_{4}\right)(\mathrm{OH}) \cdot 5\left(\mathrm{H}_{2} \mathrm{O}\right)$ \\
\hline Epsomite & $\mathrm{MgSO}_{4} \cdot 7\left(\mathrm{H}_{2} \mathrm{O}\right)$ \\
\hline Schwertmannite & $\mathrm{Fe}^{3+} 16 \mathrm{O}_{16}(\mathrm{OH})_{12}\left(\mathrm{SO}_{4}\right)_{2}$ \\
\hline Halotrichite & $\mathrm{Fe}^{2+} \mathrm{Al}_{2}(\mathrm{SO} 4)_{4} \cdot 22\left(\mathrm{H}_{2} \mathrm{O}\right)$ \\
\hline Rhomboclase & $\mathrm{HFe}^{3+}\left(\mathrm{SO}_{4}\right)_{2} \cdot 4\left(\mathrm{H}_{2} \mathrm{O}\right)$ \\
\hline Pickeringite & $\mathrm{MgAl}_{2}\left(\mathrm{SO}_{4}\right)_{4} \cdot 22\left(\mathrm{H}_{2} \mathrm{O}\right)$ \\
\hline Paracoquimbite & $\mathrm{Fe}^{3+}{ }_{2}\left(\mathrm{SO}_{4}\right)_{3} \cdot 9\left(\mathrm{H}_{2} \mathrm{O}\right)$ \\
\hline \multicolumn{2}{|c|}{ Copiapite $\mathrm{Fe}^{2+} \mathrm{Fe}^{3+}{ }_{4}\left(\mathrm{SO}_{4}\right)_{6}(\mathrm{OH})_{2} \cdot 20\left(\mathrm{H}_{2} \mathrm{O}\right)$} \\
\hline Ferricopiapite Fe & $\mathrm{Fe} 3+{ }_{4}\left(\mathrm{SO}_{4}\right)_{6}(\mathrm{OH})_{2} \cdot 20\left(\mathrm{H}_{2} \mathrm{O}\right)$ \\
\hline Szmolnokite & $\mathrm{Fe}\left(\mathrm{SO}_{4}\right) \cdot \mathrm{H}_{2} \mathrm{O}$ \\
\hline Rozenite & $\mathrm{Fe}^{2+}\left(\mathrm{SO}_{4}\right) \cdot 4\left(\mathrm{H}_{2} \mathrm{O}\right)$ \\
\hline Melanterite & $\mathrm{Fe}^{2+}\left(\mathrm{SO}_{1}\right) \cdot 7\left(\mathrm{H}_{2} \mathrm{O}\right)$ \\
\hline
\end{tabular}
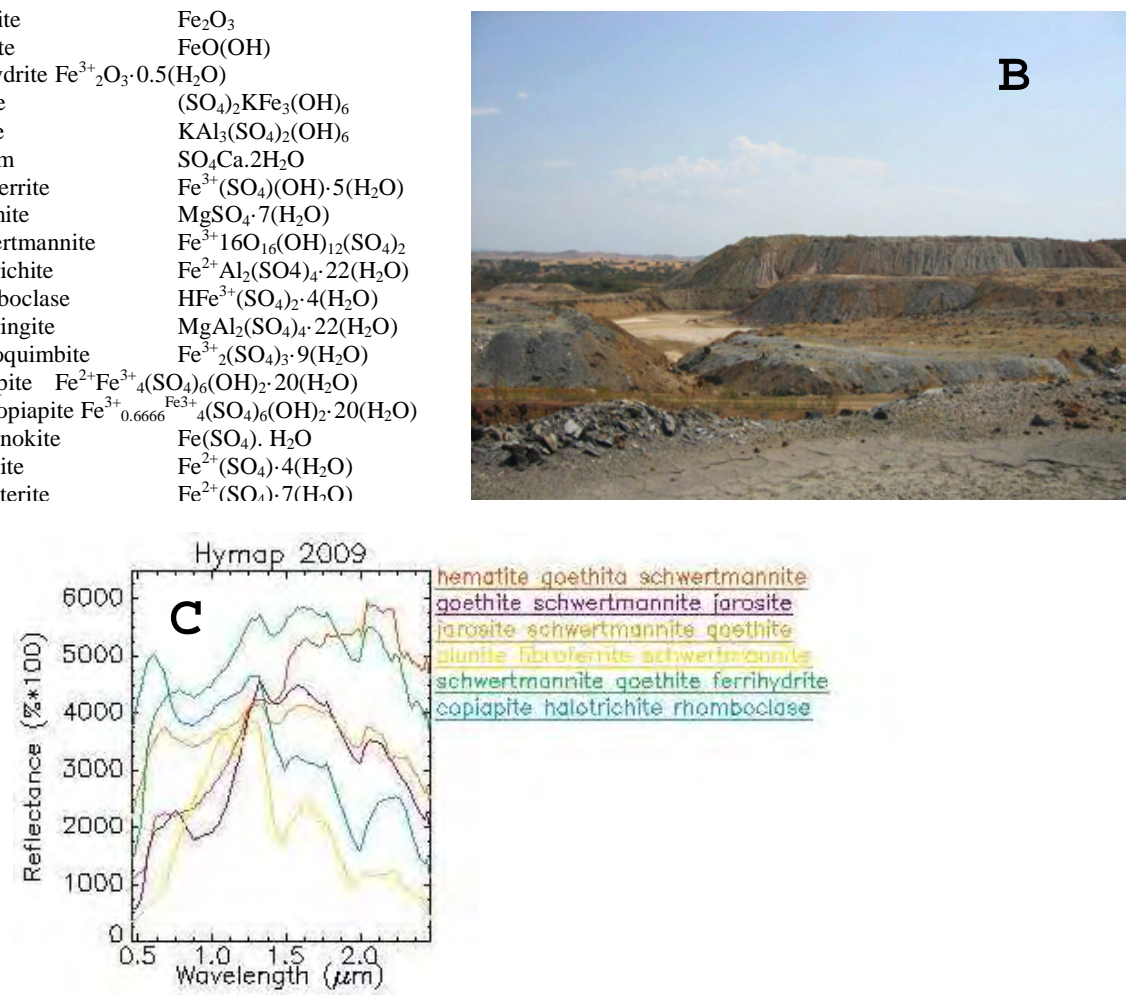

Figure 4.4. A: Map of pyrite oxidation products from Hymap data on mine dumps with legend including all minerals of the reference spectral library (Crowley et al, 2003). B: Dumps at the mine site, with typical terraced geomorphology. C: Spectral library for the endmembers used to produce the map with Hymap 2009 data, with the corresponding mineralogical diagnosis. 
Figura 4.4. A: Mapa de productos de oxidación de pirita elaborados con imágenes Hymap sobre escombreras según leyenda que incluye los minerales de la secuencia de oxidación de piritas (Crowley et al, 2003). B: Escombreras con relieve típicamente aterrazado. C: Espectroteca con los miembros extremos usados para elaborar el mapa con imágenes Hymap de 13 de Agosto de 2009, con su correspondiente diagnóstico mineralógico.

\subsubsection{Hyperion}

The maps compiled from the Hyperion data in September 2006 and August 2007 display a similar pattern of coatings (Figure 4.5A and Figure 4.5B). Hyperion data are
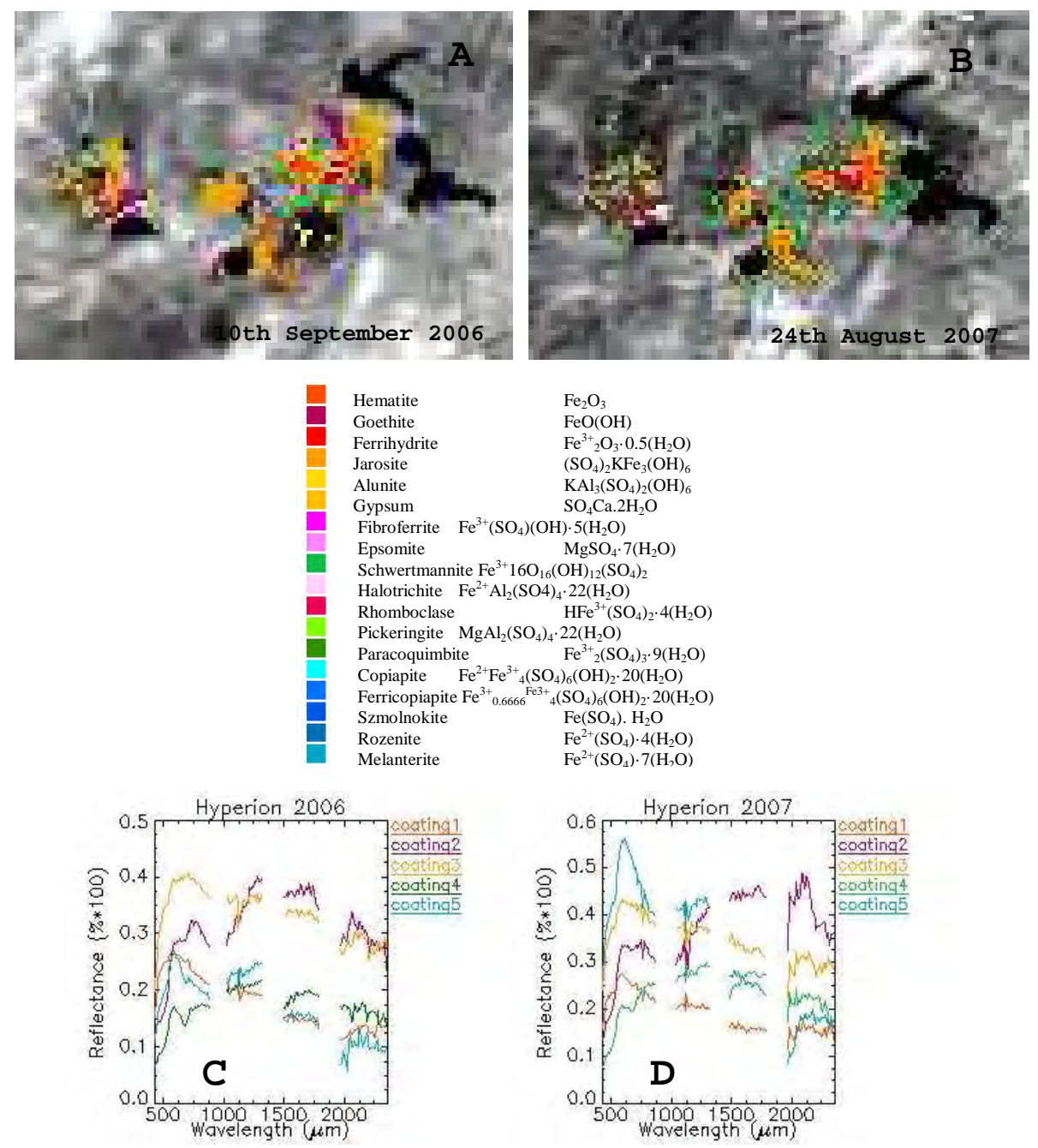

Figure 4.5. A: Map of pyrite oxidation products from Hyperion data from September 2006 on mine dumps with legend including all minerals of the reference spectral library (Crowley et al., 2003). B: Map of pyrite oxidation products from Hyperion data from August 2007 on mine dumps. C: Spectral library for the endmembers used to produce the map with Hyperion 2006 data, with the corresponding colour coded mineralogical diagnosis following legend. D: Spectral library for the endmembers used to produce the map with Hyperion 2007 data, with the corresponding colour coded mineralogical diagnosis following legend. 
Figura 4.5. A: Mapa de productos de oxidación de piritas elaborado con imágenes Hyperion de Septiembre de 2006 sobre escombreras, con leyenda que incluye los minerales de la secuencia de oxidación de piritas (Crowley et al., 2003). B: Mapa de productos de oxidación de piritas de imágenes Hyperion de Agosto de 2007 en escombreras. C: Espectroteca de miembros extremos usados para elaborar el mapa con imágenes Hyperion de 2006, con el correspondiente diagnóstico mineralógico según leyenda. D: Espectroteca de miembros extremos usados para elaborar el mapa con imágenes Hyperion de 2007, con el correspondiente diagnóstico mineralógico según leyenda.

quite noisy; therefore, there is no attempt to diagnose mineralogically the units within the mine dumps. The Hymap 2009 map is used as a reference to interpret the mapping capability of Hyperion.

As on Hymap, three main units are identified on Hyperion: the flat areas with hematite-goethite, the smooth slopes with jarosite, and the steep slopes covered by schwertmannite (Figure 4.5C and Figure 4.5D). Hydrated iron sulphate around ponds, probably copiapite, is also identified in the Hyperion data. In September 2006, there was a strong suggestion of a wide wet area flanking the eastern dumps, which does not exist in August 2007. In September 2006, there was a wider goethitic diagnosed area along the northern drainage from the eastern dump which is absent in 2007.

The Hyperion maps are noisy, and it is unlikely that the mapped units point to significant mineralogical changes from year to year. A better atmospheric correction and a wider mappable area would be necessary to achieve those goals efficiently. However, the tracing of the main units in both years, and the recorded presence of hydrated sulphate on the small humid areas is remarkable. Both observations prove the strength of the basic mapping features used in the study, and the efficiency of hyperspectral data to provide geological information with well-designed image processing and a proper understanding of the geological context.

\subsubsection{Field}

Mine dumps are arranged on terraces (Figure 4.4B) (Riaza et al., 2010a). Flat areas and slopes are geomorphological surfaces where a distinctly different mineralogical evolution can be traced. Rock and waste pebbles display a homogeneous pattern on the flat surfaces of terraces. Small ponds dry up slowly on flat surfaces and mineral growth displays a concentric pattern where oxidation and dehydration processes can be followed. On the contrary, the material on the slopes of a mine dump are dominated by 
runoff and washing during the rainy periods. Accordingly, loose material gathers along the line of maximum inclination of the slope. Strings of pebbles with different original lithologies and sizes, plus oxidation states, can be recognized along the slope.
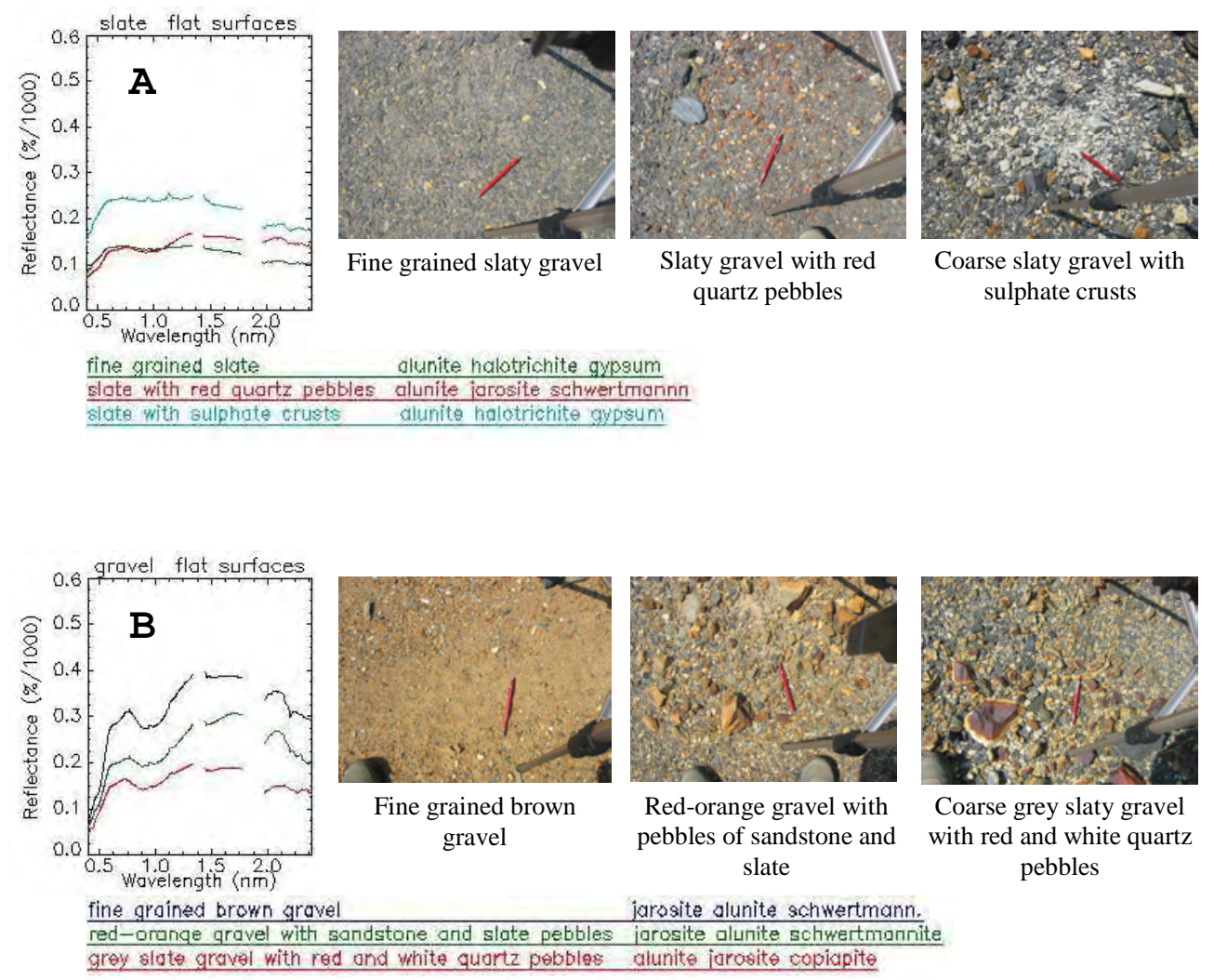

Figure 4.6. Field spectra on waste on flat surfaces of mine dumps identified as colour coded legend below, and mineralogical diagnosis according to pyrite oxidation reference library (Crowley et al., 2003). A: Dominant slate gravel with several grain sizes, pebbles and crusts on locations with lithologies shown on pictures. B: Gravel with variable lithologies and grain sizes, comparatively more oxidised than dominant slaty gravel in $\mathrm{A}$, on locations with lithologies shown on pictures.

Figura 4.6. Espectros de campo en residuos en superficies planas altas de las escombreras, y diagnóstico mineral según la espectroteca de referencia de minerales de oxidación de piritas (Crowley et al., 2003). A: Grava con predominio de granos de pizarra con distintos tamaños de grano, cantos y costras, espectros medidos en las superficies fotografiadas. B: Grava con litologías y tamaños de granos variados, comparativamente más oxidados que las gravas predominantemente pizarrosas en $A$, espectros medidos en las superficies fotografiadas.

Mine dumps, as described above, are lithologically and texturally heterogeneous. The spectral signature of any patch of a mine dump is highly mixed. However, Hymap imagery is able to display an understandable sequence of areas, which are homogeneous enough to describe a mineralogical sequence of dehydration and oxidation (Figure 4.6A). 
In the area of study, both flat surfaces and slopes differ spectrally according to the main lithology of the detrital material: whether dominant slate, or dominant oxidized quartzite and sandstone. The loose material on flat surfaces is compacted, lessening the shadow effects on their spectral response.

\subsection{Flat surfaces}

The spectra on gravels with dominant slate tend to be flat and have low overall reflectance (Figure 4.6A). If red or yellow oxidized quartzite boulders are mixed with slate, there is a smooth depression centred at $938 \mathrm{~nm}$ due to iron oxide. Sometimes, a ridge around $1137 \mathrm{~nm}$ occurs, indicating the growth of sulphate hydrated crusts. When grey slate begins to colour by oxidation or show suggestions of the development of crusts of hydrated sulphate, their spectra show a hook at $435 \mathrm{~nm}$.

Brown gravel or slate with red pebbles show spectra with a well developed wide depression centred at $938 \mathrm{~nm}$ (Figure 4.6B). Only the spectra on coarser pebbles display the hook at $435 \mathrm{~nm}$. The absorption at $2256 \mathrm{~nm}$ is also smoothed.

Fine grained or medium size brown gravels, and pebbles on gravels, display the absorption at $2205 \mathrm{~nm}$. If there are coarser pebbles, an absorption at $2256 \mathrm{~nm}$ occurs.

\subsection{Slopes}

The slope of a mine dump offers more heterogeneous and unstable detrital material than the flat surfaces on top. Grain sizes are more heterogeneous, and the whole mass is loose, increasing shade effects on the spectral response. As cracks open more easily on slopes, crusts of hydrated sulphate burst to the surface along cracks opened by upwelling movements inside the dump on the sliding mass.

Along slopes, the brown and reddish sliding gravels display spectra similar to the oxidized gravels occurring on flat surfaces (Figure $4.7 \mathrm{~A}$ ). The difference is a homogeneous higher overall reflectance, and enhanced iron oxide bearing spectral features: the wide depression centred at $892 \mathrm{~nm}$, and absorptions in the NIR at 2031, 2211 and $2214 \mathrm{~nm}$. Also, all spectra display the ridge at 1126 associated with the presence of hydrated sulphate crusts, and lack the hook at $435 \mathrm{~nm}$, which occurs on oxidized slate. 


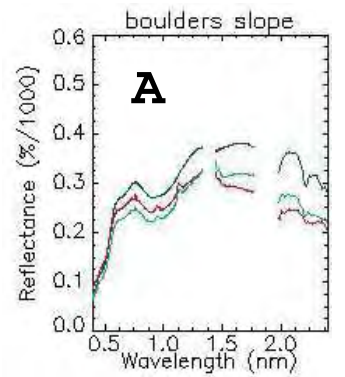

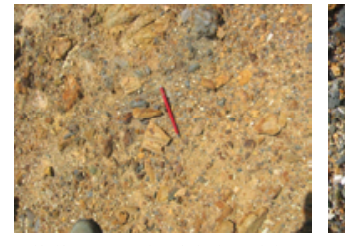

Sliding mud with boulders of slate and yellow sandstone

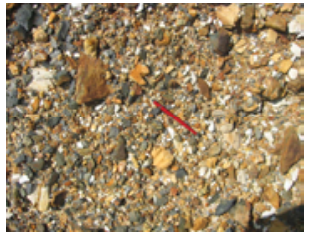

Boulders of red and white slate HALOTRICHITE ALUNITE RYPSUM black slate and quartz ALUNITE HALOTRICHITE GYPSUM black and rad siat $\theta$ and guartz ALUIVITE HALOTRICHITE GYPSUM

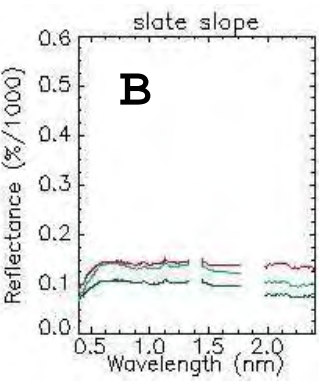

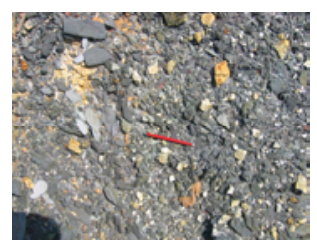

Black slate

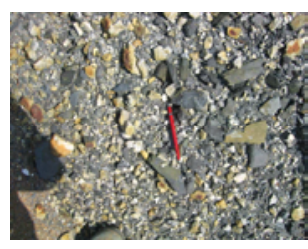

Black slate and yellowgreen quartz

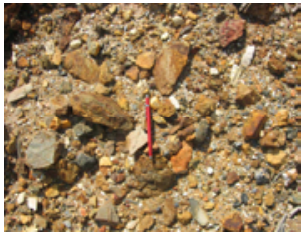

Boulders of slate, sandstone and red quartz

Figure 4.7. Field spectra on waste on slopes of mine dumps, and mineral diagnosis according to pyrite oxidation reference library (Crowley et al., 2003). A: Dominant oxidised boulders with several lithologies and grain sizes on locations with lithologies shown on pictures. B: Boulders of dominant slate with variable grain sizes, on locations with lithologies shown on pictures.

Figura 4.7. Espectros de campo en residuos en taludes de escombreras, y diagnóstico mineral según la espectroteca de referencia de minerales de oxidación de piritas (Crowley et al., 2003). A: Cantos predominantemente oxidados de distintas litología y tamaños, espectros medidos en las superficies fotografiadas. B: Cantos predominantemente pizarrosos con tamaños de grano variados, espectros medidos en las superficies fotografiadas.

As on the flat surfaces, the spectral response of pebble gravels relies mainly on the dominant lithology. The gravels with dominant slate tend to develop flat and low overall reflectance spectra, with smoothed features and lower overall reflectance than the slaty flat surfaces, due to shade effects (Figure 4.7B). However, the ridge centred at $1126 \mathrm{~nm}$ typical of the occurrence of hydrated sulphate crusts can be recognized, as well as the hook at $435 \mathrm{~nm}$ associated with increased oxidation. 
The mineral diagnosis of the materials on mine dumps using their spectral response and the reference spectral library on mineralogical iron sulphide weathering products (Crowley et al., 2003) also follows identifiable trends (Figure 4.7A and Figure 4.7B). This mineral diagnosis on heterogeneous mixtures of rocks and weathering minerals needs a careful lithological and geomorphological evaluation (Riaza et al., 2010a).

The slaty gravels on top of flat surfaces are identified as alunite and halotrichite (Figure 4.7B). The third mineral diagnosed is gypsum, when the gravel is homogeneously slaty, and schwertmannite when red quartzite pebbles are present. This is consistent with the increased oxidation state of the heterogeneous lithology. On slopes, the slaty gravels are identified as halotrichite and alunite, with gypsum as the third diagnosed mineral. When there are reddish quartzite pebbles, jarosite is included among the three diagnosed minerals.

The brown and reddish quartzite and sandstone gravels are more often identified as jarosite, alunite and schwertmannite (Figure 4.7A). This is also true for the same lithologies on slopes. The only difference is the more frequent diagnosis of copiapite as the third mineral on flat surfaces when the grain size is coarser and slate pebbles are more obvious. This would wrongly indicate a weaker tendency to oxidization on flat surfaces, which contradicts the general observations on the imagery (Riaza et al., 2010a).

Alunite is not a pyrite weathering product, and is replaced by copiapite in the diagnosis when excluded from the reference spectral library. The mineralogical diagnosis described would conclude that slate, whether on flat surfaces or slopes, displays preferences to host hydrated sulphate. Slate jeopardizes the presence of absorption features on their spectra, and does not oxidize easily. However, there is the suggestion of slaty gravels on the slope to show the ridge at $1126 \mathrm{~nm}$ associated to the presence of hydrated sulphate crusts.

\subsection{Dry mill tailing ponds}

The abandoned mill tailing ponds are dry and display a flat bottom covered by desiccated mud or fine grained sand or gravels (Figure 4.8A and Figure 4.8B). The exposed mud is a coating of a few millimetres to a few centimetres over reddish quartzite gravels. All spectra display a wide depression centred at $892 \mathrm{~nm}$, and an ascent towards longer wavelength ranges (Figure 4.8C). The spectral features of mud 
are smoothed compared to the spectra of orange coloured sands and gravels. All spectra display the ridge at $1126 \mathrm{~nm}$ associated to the presence of hydrated sulphate crusts.
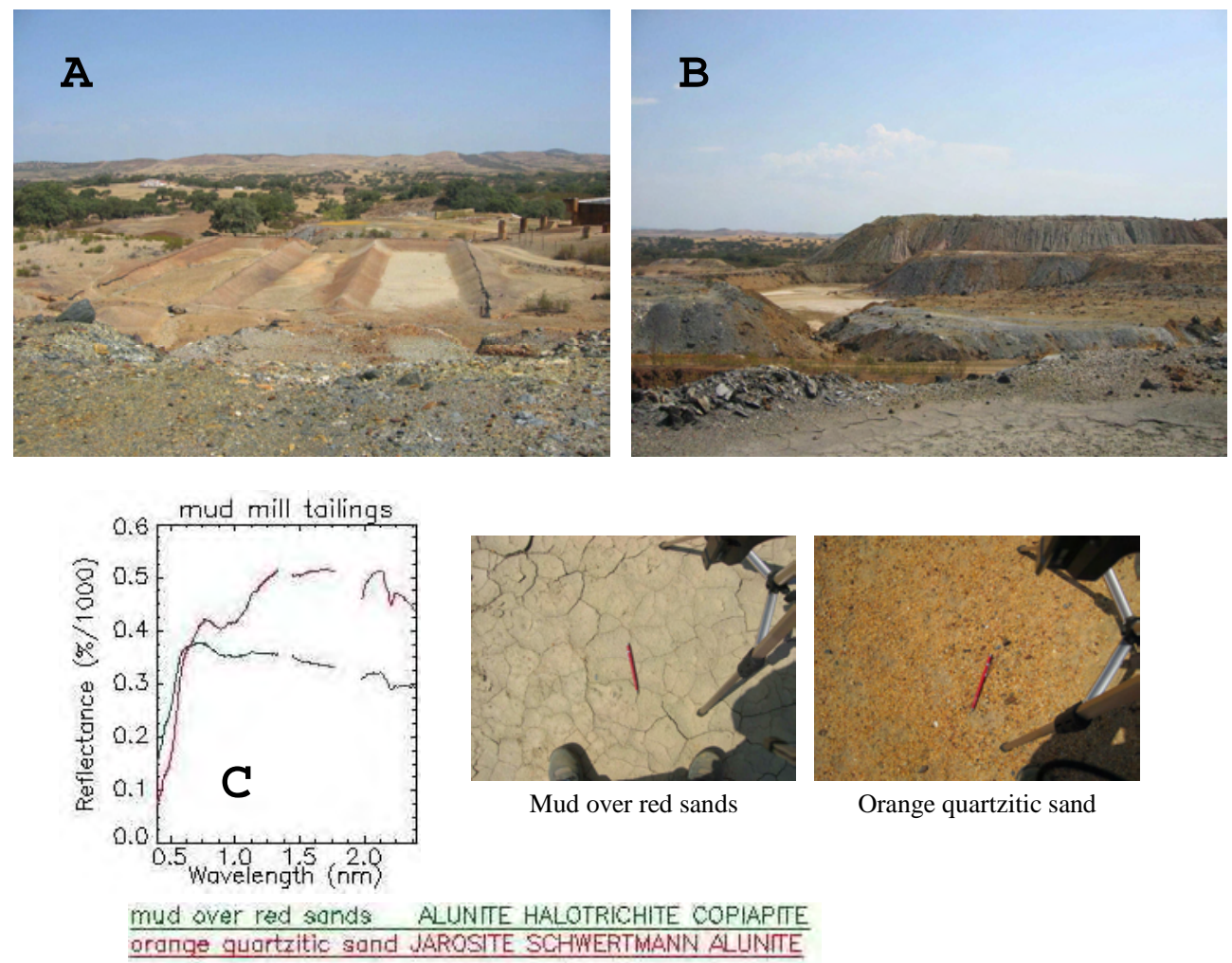

Figure 4.8. A. Dry mill tailings ponds. B: Typical geomorphology of dumps with terraces, and ponds on low flattened spaces. C: Field spectra on waste on mill tailings ponds, and mineral diagnosis according to the pyrite oxidation reference library

(Crowley et al., 2003) on locations with lithologies shown on pictures.

Figura 4.8. A: Balsas de lodos secas. B: Escombreras con geomorfología típica en terrazas, $y$ balsas en las depresiones aplanadas. $C$ : Espectros de campo en residuos de las balsas de lodos, con diagnóstico mineral según la espectroteca de referencia de minerales de oxidación de piritas (Crowley et al., 2003), medidos en superficies fotografiadas.

The dry mud covering the bottom of the mill tailing ponds is mineralogically diagnosed as alunite halotrichite jarosite, or alunite jarosite schwertmannite (Figure 4.8C). The orange coloured sand is diagnosed as jarosite schwertmannite ferrihydrite, comparatively far more oxidized than mud. Dry mud is diagnosed to be in a hydrated sulphate mineralogical phase. How stable are those hydrated sulphates? It is very likely that this mud hydrates every winter to maintain the hydration for the next summer, otherwise the underlying red sands rapidly filter the water, preventing humidity for a long time. 
Moreover, the oxidized orange coloured sand displays the ridge of hydrated sulphate, which does not appear in any known reference library. It could be noise produced by the change of detector in the field spectrometer. Nevertheless, it does not appear on all consecutive spectra in a session, and is clearly associated to lithologies and geomorphologically identifiable locations.

We can conclude that the bottom of the mill tailing ponds shows a spectral hydrated state preserved by the yearly available humidity on the coatings of minerals present.

\subsubsection{WATER}

The operation of the mine site stopped in the 8os, and drainages, old lixiviating ponds and water reservoirs do not receive industrial supplies any longer. Two main open pits are flooded with water: the so-called "pyrite" open pit and the "copper" open pit (Figure 4.1). The water from the copper open pit drains to a series of three lixiviating ponds sequentially washing the metal contents.

Three dams storing rainwater which supplied water for mine operations are located to the east. Two of them supply water to the nearby towns today, and the third collects the towns' sewage (Figure 4.1).

The lakes filling the open pits at the mine site have high sulphate contents (pyrite open pit: $2093 \mathrm{mg} / \mathrm{L}$; “copper” open pit: $3240 \mathrm{mg} / \mathrm{L}$ ). The pyrite open pit has an acid pH of 3. The water filling the "copper" open pit has increased sulphate contents (10708 $\mathrm{mg} / \mathrm{L}$ ), with significant sodium, potassium, calcium, bromides and chlorides, and a lower acid $\mathrm{pH}$ of 6 . The water filling the small lixiviating ponds recovers an acid $\mathrm{pH}$ of 2.7, with concentrates of sulphate and fluoride in comparison to the "pyrite" and "copper" open pits, and with sodium, potassium and magnesium washed out. The metal content, already high in the "pyrite" open pit, increases through the "copper" open pit to a significant concentrate in the water of the lixiviating ponds.

The water stored in the rainwater dams shows reduced contents of the mentioned elements. The fresh water dam displays a neutral $\mathrm{pH}$ 7.1, with only outstanding bicarbonate content. The dam storing urban sewage shows a basic $\mathrm{pH}$ 9, and outstanding chloride, bicarbonate, carbonate, and phosphate, as well as small quantities of fluoride, and bromide. The content of metals is irrelevant in this fresh water compared to that of the open pits, with the exception of the urban sewage water, which contains comparatively higher vanadium, molybdenum, antimony, and barium. 


\subsubsection{Hymap}

The spectra from water bodies on Hymap data (Figure 4.9A) on the mine site show a narrow peak with a maximum at $0.558 \mu \mathrm{m}$, descending steeply towards $0.660 \mu \mathrm{m}$ (Fig. 9C). The peak of reflectance of water in urban dams is wider (Figure 4.9D), and the descent towards longer wavelength ranges varies.
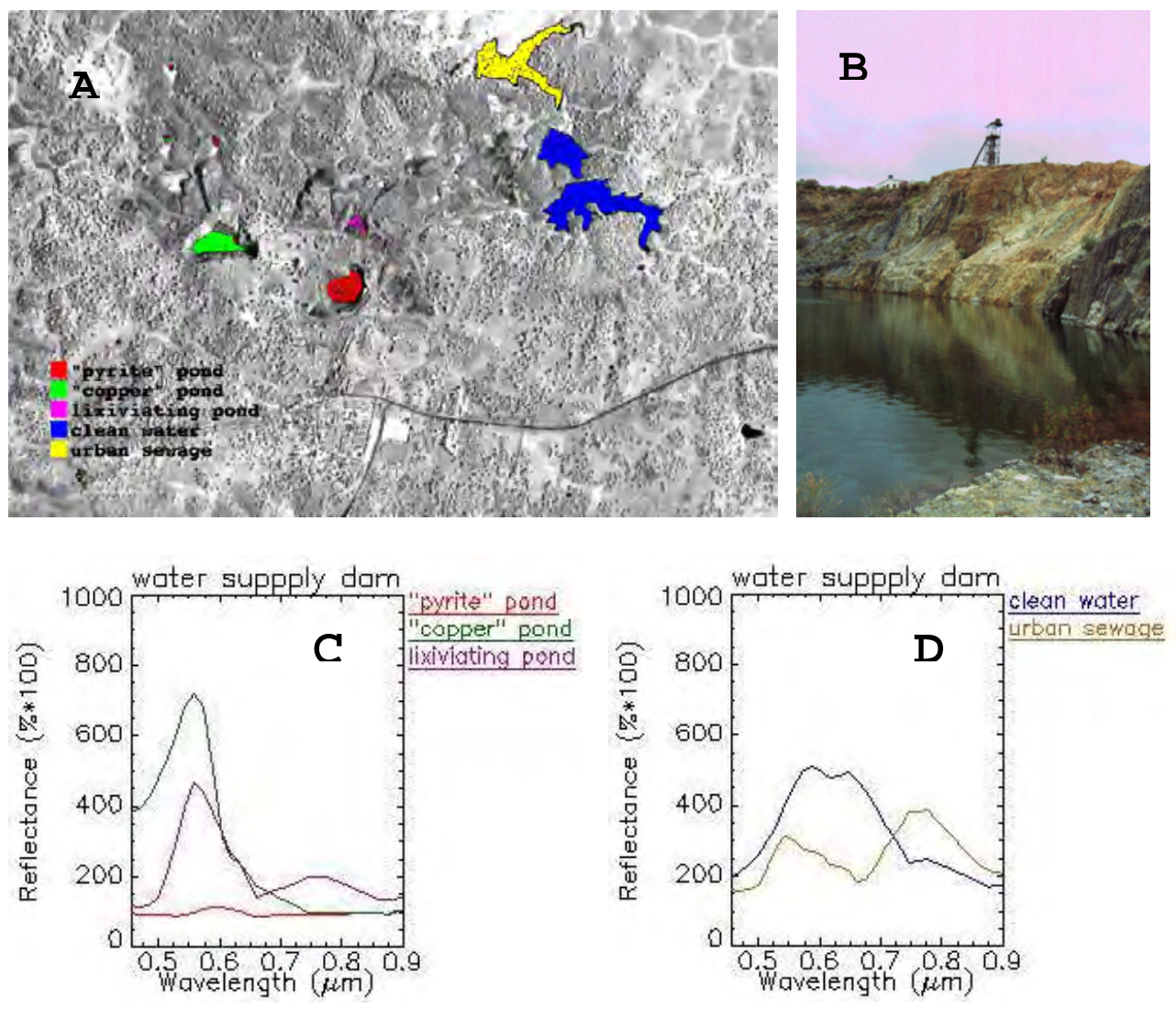

Figure 4.9. A: Map of water bodies compiled from Hymap data. B: View of the "copper" pond. C: Spectra from Hymap data on the mine water bodies. D: Spectra from Hymap data on the water supply dams.

Figura 4.9. A: Mapa de cuerpos de agua elaborado con imágenes Hymap. B: Vista de la "balsa de cobre". C: Espectros de imágenes Hymap en los cuerpos de agua de las cortas de la mina. D: Espectros de imágenes Hymap en los embalses de abastecimiento de agua cercanos.

The spectra of water at the pyrite pond show a weak peak with a maximum at 0.588 $\mu \mathrm{m}$, which is not typical of acid mine waters and considerably lower than the copper pond, with a neutral pH (Figure 4.9B and Figure 4.9C). The reflectance pattern at the pyrite pond is quite heterogeneous. Wind producing a wavy surface may influence this 
anomalous reflectance response. The water at the small pond in the dumps has a typical acid water shape, but the overall reflectance is less than the water at the copper pond.

The Hymap spectra on water at the mine site do not follow the trends observed in the field on stream waters (Riaza et al., 2010b; 2012a) or in the literature (Anderson and Robins, 1988). Unlike stream water, water ponds on mine sites are deep and seem spectrally homogeneous, showing no optical depth variations, nor influence of the bottom or changes in suspended sediment concentration, apart from the half metre from the shore. The spectral features on those deep-water bodies may follow different spectral behaviours than shallow stream waters. However, Hymap data have easily mapped the differences on their chemical composition, summarized by $\mathrm{pH}$.
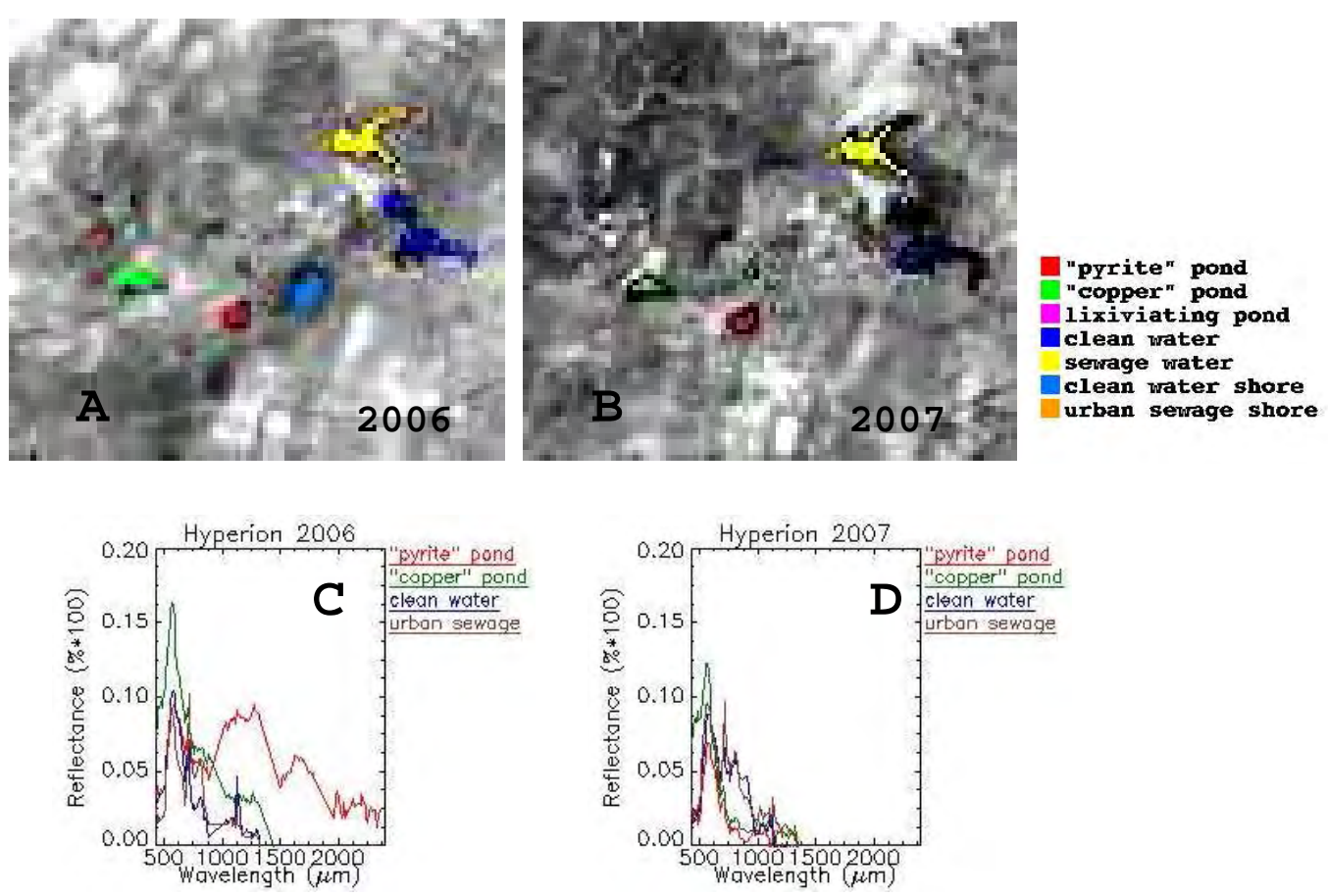

Figure 4.10. A: Map compiled from Hyperion 2006 for water bodies. B: Map compiled from Hyperion 2007 for water bodies. C: Spectra of water bodies from Hyperion 2006 data. D: Spectra of water bodies from Hyperion 2007 data.

Figura 4.10. A: Mapa de cuerpos de agua elaborado con imágenes Hyperion de 2006. B: Mapa de cuerpos de agua elaborado con imágenes Hyperion de 2007. C: Espectros de cuerpos de agua de datos Hyperion 2006. D: Espectros de cuerpos de agua de datos Hyperion 2007. 


\subsubsection{Hyperion}

Hyperion data accurately map the flooded open pits within the mine dumps, small lixiviating ponds and water reservoirs as spectrally diverse, both in 2006 and 2007 (Figure 4.10A and Figure 4.10B). In addition, the mixed pixels of shallow water and land along the shore of the rainwater dams can be mapped.

The Hyperion spectra of water bodies (Figure 4.10C and Figure 4.10D) faithfully follow the field spectra collected on them used for the calibration of the imagery. Accordingly, all the observations on water field spectra faithfully follow the Hyperion data

\subsubsection{Field}

The spectra of water at the "pyrite" open pit show a typical acid water response ( $\mathrm{pH} 3$ ) (Figure 4.11). There is a peak of reflectance between $494 \mathrm{~nm}$ and $737 \mathrm{~nm}$ with a maximum at $580 \mathrm{~nm}$, a shoulder at $612 \mathrm{~nm}$ and an inflexion point at $681 \mathrm{~nm}$.

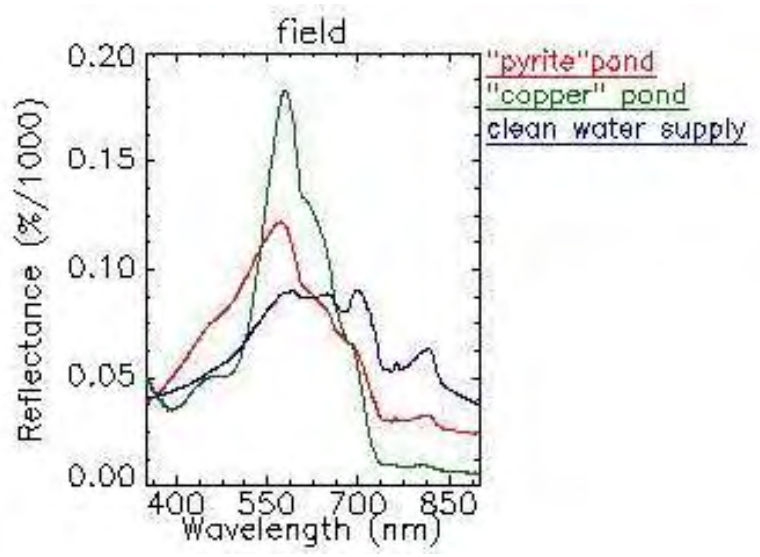

Figure 4. 11. Field spectra from mine water bodies and the clean water supply dam.

Figura 4.11. Espectros de campo en las balsas de agua de las cortas mineras, y en el embalse de abastecimiento de agua.

The water spectral measurements on the ponds of the mine site differ from the usual spectra on estuarine and coastal waters (Brando and Dekker, 2003) and inland waters (Dekker and Hoggedom, 1996), on the enhancement of the peak of reflectance at 579 $\mathrm{nm}$, and the comparative smoothing of the chlorophile a $674 \mathrm{~nm}$ absorption. The acid water with high sulphate content inhibits the biomass development, and the absorption features, typical of photosynthetic pigments, are absent on their spectra. 
The "copper" open pit, with less acid pH 6, gathers the same spectral features as the pyrite open pit, comparatively smoothed (Figure 4.11). The ascent towards $580 \mathrm{~nm}$ is continuous and far less steep, with a soft shoulder at $494 \mathrm{~nm}$, descending with a minor slope towards $737 \mathrm{~nm}$, with smooth shoulders at 612 and $681 \mathrm{~nm}$. This spectral measurement can be considered as a standard inland eutrophic water spectrum, apart from the enhanced $580 \mathrm{~nm}$ peak.

The spectra of the water stored at the dam feeding clean water to the nearest town, differs from the spectral response of both ponds in the mine site (Figure 4.11). There is a continuous ascent towards $580 \mathrm{~nm}$, and the descent towards longer wavelength ranges develops waves with minimums coinciding with shoulders on the reflectance of water at the mine site.

The spectra from clean freshwater display a wavy spectral response because of highsuspended sediment concentrations and the influence of the spectral response of the bottom of the shallow water where it was measured (Figure 4.11).

\subsection{DISCUSSION}

The maps compiled from Hymap and Hyperion data display the same trend of mineralogical mixtures on the units mapped, controlled by the geomorphology of the mine dumps. The maps compiled with Hymap data were used as a reference, guiding image processing on Hyperion, with noisier and lower resolution data. Surprisingly, Hyperion was not only able to display the main units mapped with Hymap, but also small areas of former ponds or topographically low areas covered mainly with hydrated sulphate. Hyperion 2007 shows a wide area suggesting the presence of humidity which is absent in 2005 and 2006.

The areas where hydrated sulphate occurs are critical as indicators of changes in the mineralogy related to climate fluctuations. Field spectra show typical hydrated sulphate shapes in areas which were used as lixiviating ponds twenty years ago. The surface measured with the field spectrometer is a thin coating over sands, with minerals dissolving with rain events and re-precipitating once there is less humidity available. The speed at which this crust dissolves and re-precipitates and the range of changes in temperature and humidity necessary for significant mineralogical changes are not yet clear. 
The spectral response of water bodies is strikingly variable, both on ponds within the mine facilities, and dams for water supply. Spectra are sensitive to the geochemistry of the water, and maps produced relate directly to water quality parameters, such as $\mathrm{pH}$. However, there are discrepancies in the typical spectral features associated with the increase in acidity of running water, between the water in the two main open pits on the mine site. Both Hymap data and field spectra agree on the spectral differences. Water depth, wind influence, or the geochemistry of the water can be part of the unknown reason for the discrepancies.

\subsection{CONCLUSIONS}

Both Hymap and Hyperion are able to map the main units of mineralogical assemblages over mine dumps, responding to strong geomorphological controls.

Hyperion is able to map some small areas of hydrated minerals in depressions and the neighbourhoods of ponds and water bodies.

Both Hymap and Hyperion are able to discriminate spectrally water bodies related to their chemical contents, whether within the mine site, or the nearby water supply dams.

To a certain extent, Hyperion data is able to map spectrally the shore of the main water bodies with shallow water and turbidity or bottom transparency. Moreover, Hyperion can discriminate small water bodies with a low acid $\mathrm{pH}$ and high heavy metal content, hosting water used in the lixiviation of ore.

Therefore, Hyperion is a useful sensor in providing a panoramic view of the oxidation state of mine waste on a regional scale on land, and the water quality of water bodies. 


\section{CHAPTER 5}

\section{MAPPING A CONTAMINATED RIVER COURSE WITH HYMAP DATA (RIVER ODIEL, HUELVA, SW SPAIN)}

\subsection{INTRODUCTION}

Imaging Spectroscopy has been developed as an effective tool to study mine waste deposits generating acid mine drainage (Plumlee, 1999). Spectral libraries are gathered for the purpose (Crowley et al., 2003) enabling a quick mineral diagnosis of ephemeral thin crusts concentrating heavy metals, precipitated from acid water.

The River Odiel (Huelva, southwest Spain) runs through the Iberian Pyrite Belt, a wide geological unit within the Hesperian Massif hosting massive sulphide deposits exploited along 5000 years (Figures 1.1 and 1.2). Pyrite is abundant both on mine waste and rock outcrops, and acid mine drainage is present in most drainages throughout the region (Sarmiento et al., 2009).

The Pyrite Belt consists of a thick sequence of volcanoclastic sediments with interstratified quartzite, sandstones and slates, at the foot of the northern Sierra de Aracena, where igneous rocks outcrop. The landscape is a smooth ridge-valley alternation, with an average elevation difference of $100 \mathrm{~m}$.

The river flows across stratification in a low sinuosity channel controlled by lithology. The general flow path is linear in N-S direction with minor deviations when crossing more competent rock layers, where rests of watermills are always present. River bars develop along the river course, with increasing size down waters. The Odiel River can be considered a bedload transport stream with low sinuosity and considerable lateral mobility, with dominant transport of fine grained detritics with occasional coarse material at intense rain events (Rodriguez Vidal et al., 1991). The mobile channels are subdivided internally into changing paths of sub channels and braided bars

At the last part of the river before entering the estuarine marshes, the slopes are steep, and alternating braided bars develop widely under a systematic grain size sediment pattern. 


\subsubsection{GEOCHEMISTRY OF THE CONTAMINATION}

The river Odiel receives acid and contaminated waters from the numerous mine sites in the basin. Weathering of pyrite and other sulphides generates acid waters and ironbearing sulphate and other secondary minerals (Nordstrom and Alpers, 1999). Oxidation of pyrite results on the generation of sulphuric acid. Low $\mathrm{pH}$ waters are able to release heavy metals contained in the rocks and disperse them into the environment, affecting the quality of waters and the river sediments.

The mining activity intensifies the acid mine drainage (AMD) processes, by rock crushing and grinding, which increases the surface area of the sulphides than can react (Plumlee, 1999). This process also takes place naturally when mineralized outcrops are exposed to the atmospheric weathering, but its intensity is increased by human activity.

The oxidative dissolution of pyrite is a studied geochemical process on the surface of the Earth, even though it is not completely understood (Nordstrom and Alpers, 1999). The chemical reaction (1) describes the oxidation of pyrite in the presence of water and oxygen:

$\mathrm{FeS}_{2(\mathrm{~s})}+3 \cdot 5 \mathrm{O}_{2}+2 \mathrm{H}_{2} \mathrm{O} \rightarrow \mathrm{Fe}^{2+}+2 \mathrm{SO}_{4}{ }^{2-}+2 \mathrm{H}^{+}$

When pyrite is exposed to the oxygen and water is oxidized, it releases $\mathrm{Fe}^{2+}$ and $\mathrm{SO}_{4}{ }^{2-}$, and also produces sulphuric acid $\left(\mathrm{H}_{2} \mathrm{SO}_{4}\right)$ and ferrous sulphate $\left(\mathrm{FeSO}_{4}\right)$. The sulphuric acid produces a decreasing in the $\mathrm{pH}$ level of waters.

The ferrous ion released in the previous reaction is oxidized into ferric ion (reaction 2) or can be incorporated to sulphate ions under non-oxidizing conditions, forming soluble sulphate minerals like melanterite $\left(\mathrm{FeSO}_{4} \cdot 7 \mathrm{H}_{2} \mathrm{O}\right)$, rozenite $\left(\mathrm{FeSO}_{4} \cdot 4 \mathrm{H}_{2} \mathrm{O}\right)$ or szmolnokite $\left(\mathrm{FeSO}_{4} \cdot \mathrm{H}_{2} \mathrm{O}\right)$ (Hammarstrom et al., 2005).

$14 \mathrm{Fe}^{2+}+3 \cdot 5 \mathrm{O}_{2}+14 \mathrm{H}^{+} \rightarrow 14 \mathrm{Fe}^{3+}+7 \mathrm{H}_{2} \mathrm{O}$

At $\mathrm{pH}$ lower than 3.5 the reaction 2 is quite slow, but the presence of acidophilic bacteria (Acidithiobacillus ferroxidans, Leptospirillum ferroxidans) accelerates in two magnitude orders the reaction velocity, maintaining a high concentration of $\mathrm{Fe}^{3+}$ in the system (Singer and Stumm, 1970, Nordstrom and Alpers, 1999). 
The hydrolysis of iron (reaction 3) is the responsible of formation of ferric hydroxides, which causes the appearance of red and orange coatings along water streams affected by acid mine drainage.

$\mathrm{Fe}^{3+}+3 \mathrm{H}_{2} \mathrm{O} \rightarrow \mathrm{Fe}(\mathrm{OH})_{3}+3 \mathrm{H}^{+}$

The precipitation of ferric hydroxides depend on $\mathrm{pH}$ level, and only takes place spontaneously at $\mathrm{pH}$ higher than 2.5. Nevertheless, bacterial activity can activate this reaction at lower $\mathrm{pH}$ (Salomons, 1995).

The ferric hydroxides that precipitate at this stage are jarosite, schwertmannite, ferrihydrite and goethite. It also occur mixtures of minerals, as schwertmannite and ferrihydrite or ferrihydrite and goethite (Bigham et al., 1996).

The released $\mathrm{Fe}^{3+}$ in reaction 2 allows the precipitation of ferric hydroxides by hydrolysis (reaction 3) and hydrated sulphates (reaction 4). $\mathrm{Fe}^{3+}$ is able to oxidize pyrite in anoxic and subaqueous conditions in much faster rate than the molecular oxygen.

$\mathrm{FeS}_{2(\mathrm{~s})}+14 \mathrm{Fe}^{3+}+8 \mathrm{H}_{2} \mathrm{O} \rightarrow 15 \mathrm{Fe}^{2+}+2 \mathrm{SO}_{4}{ }^{2-}+16 \mathrm{H}^{+}$

During this reaction, the $\mathrm{pH}$ of water is very low due to the releasing of hydrogen ions.

These series of reactions evidence that significant amounts of sulphuric acid are released into the aquatic environment.

A sequence of salts from early to later formed is established from a solution of pyrite (Buurman, 1975; Alpers et al., 2003). The geochemical sequence is explained widely in Chapter 1.3.

These secondary minerals precipitate over the river sediments as crusts and efflorescences. They appear over the slopes of the flow path, riverbars, boulders and into the pores of the rock boulders. Most of the precipitated minerals are unstable and are dissolved and transported during intense rain events in October. If the oxidation is intense they can be stabilized as oxidized phases, such as goethite and hematite, which act as a cement of the fluvial sediments and seal the bottom of the river path to infiltration of contaminated waters.

Mine works drain to the water flow of the Odiel basin. Most released sulphate and metal loads is estimated to remain as solid inside the basin (Sánchez España et al. 2005), and the rest dissolved substances flow to the Atlantic Ocean. 
The substances in the basin have a complex geochemical evolution that implies dissolution, precipitation, formation of ephemeral crusts and efflorescences and geochemical changes controlled mainly by climate.

\subsubsection{ACID MINE DRAINAGE ON THE RIVER ODIEL}

The precipitation regime in Huelva consists of intense and short rain events in fall, relatively dry winters, and dry spring and summer. The river carries acid waters with products from solution of iron sulphide during flash floods. After the annual main flash flood in October, sediments loose water and oxidize continuously during the winter, spring and summer.

Most of sulphate and metal loads released by mine waste is estimated to remain as solid inside the basin of the river (Sanchez España et al., 2005). Nevertheless, the rest of the dissolved contaminants flowing yearly to the estuary and the Atlantic Ocean amount are about several thousand tonnes.

The River Odiel receives contaminated water from numerous mines in the basin, and the average $\mathrm{pH}$ is 3.51 (Sarmiento et al., 2009). The concentration of heavy metals fluctuates over the year. The hydrochemical and mineralogical acid mine drainage processes vary depending on the season, the contamination level and the location on the basin (Olias et al., 2006, Sarmiento et al., 2006, 2009). In autumn, with the first rains, the anion $\mathrm{SO}_{4}{ }^{2-}$ and the metal concentration increase, while $\mathrm{pH}$ and $\mathrm{HCO}_{3}{ }^{-}$ decrease by weathering of sulphide present in the area.

Along the River Odiel, most elements show a similar evolution in concentration. The concentration of heavy metals increases during the dry season and decreases during the wet season (Sarmiento et al., 2009) as a general trend. However, immediately after the autumn intense rains, there is an increase in the concentration of some elements on the lower part of the river, by solution of soluble salts. The mineral saturation indexes also show variations along the seasons depending on the location along the river (Sarmiento et al., 2009).

At the estuary of the river, as a general trend, the most conservative elements including sulphate, $\mathrm{Al}, \mathrm{Cd}, \mathrm{Co}, \mathrm{Li}, \mathrm{Mn}, \mathrm{Ni}$ and $\mathrm{Zn}$ reach a maximum in autumn, a minimum in winter, and a concentration recovery all through spring and summer (Cánovas et al., 2007). Arsenic, on the other hand, shows low values in the summer. 
Metals and metalloids sink in the estuarine sediments due to $\mathrm{pH}$ and salinity changes (Nieto et al., 2007). Contaminants are more available on the fresh water environment.

Ribbons of different mineral growth precipitate from acid water on crusts over the sediments are obvious along the slopes of the flow path and along the water edges. Precipitates are also present over coarse washed boulders, hosted in the pores of the rock. Most of those minerals are unstable and are dissolved or transported in intense rain events. If oxidation is intense, they can be transformed to stable phases as goethite or hematite, acting as permanent cement of fluvial sediments, and sealing the bottom of the river flow path to water infiltration.

This study concentrates on the last part of the river before entering the estuary, where the average $\mathrm{pH}$ is 3.5 (Sarmiento et al., 2009), already under tidal influence.

\subsubsection{GEOMORPHOLOGICAL AND HYDRODYNAMICAL SETTING}

The Odiel River flows across various strata in a low sinuosity channel controlled by floodplain lithology. The general flow path is linear with minor deviations when crossing more competent rock layers, where water retention and diversion walls from historic watermills are abundant. Depositional bars develop along the length of the river, increasing in size downstream. The Odiel River can be considered a bedload transport stream with low sinuosity but considerable lateral mobility. The channels shift into different paths, resulting in braided side channels separated by sand and gravel bars. In the furthest downstream reaches, immediately before the estuarine marshes, the banks tend to be steeper and the braided bars demonstrate a systematic grain size sediment pattern.

The manner in which alluvial sediments are deposited along the river, primarily on bank-attached pebble bars, is the product of the type and quantity of the bed load and the degree of channel curvature. The deposits are dominated by coarser materials, mainly gravels and sands. Suspended fine-grained sediments are left as overbank sediments that plug abandoned channels. Short-term changes are superimposed, and sediments may undergo complex episodes of erosion and deposition.

Vertical profiles of lozenge-shaped bars have upper layers of larger pebbles and sandy fringes. The upper surfaces of longitudinal bars also commonly show a gradual reduction in clast size from upstream to downstream. The clast size of the bar-top at its upstream end is the same as that of the flanking channel into which it grades, but at the 
downstream end the bar-top sediments are markedly finer than the sediments of the adjacent channel floor. When water levels are low, bar margins may be draped with wedges of sand after gravel movement has stopped (Collinson, 1978). When channels are abandoned during low water, the channel floor is covered by finer sediment, first sand, and later by formerly-suspended silt or mud. These very fine sediments may eventually dry out, forming clay clasts by cracking and curling. Mud clasts are often layered, suggesting several stages of flooding and desiccation.

Typically, bars in the lower river reaches display a top of coarse, heterogeneous rocks less than $10 \mathrm{~cm}$ in diameter. As the river approaches the estuary at the Atlantic Ocean, hydrodynamic changes occur that result in a thinning of the size of bar sediments, dominated by sands with reduced pebble tops. As the river channels widen the bars become more stable with vegetation growth, and larger areas of mud bars develop.

In the lower reaches of the river, tides move salt water in and out of the estuarine segments. The marine water is characterized by a basic $\mathrm{pH}$ that influences in the acid mine drainage geochemistry and the resulting mineral growth. The present study investigated how hyperspectral imagery can detect the tidal influence on both sediments and river water before entering the estuarine marshes.

\subsubsection{CLIMATE CHANGE: INFLUENCE ON THE RIVER}

Climatology is the most important factor influencing the geochemical evolution of the secondary minerals that occur in the margins of the river.

The regional climate follows a Mediterranean climate trend smoothed by the influence of the Atlantic Ocean (Font Tullot, 1983). The Mediterranean climate is characterized by a wet season from October through May, and a dry season from late May through the summer. The insulation rate is extremely high throughout the year. Low precipitation rate defines a semi-arid climate with permanently low water table.

Dry climatic conditions causes an intense evaporation of waters and the precipitation as crusts and efflorescences of the dissolved sulphates that the river carries. They precipitate over the river sediments and start a continuous oxidation during the winter, spring and summer, following a well known mineral sequence (Buurman, 1975).

On the span of years 2004-2009 of the available Hymap flights, the climatology has changed remarkably (Figure 5.1). Taking the climatological yearly estimations based on 


\begin{tabular}{|l|l|l|l|l|l|l|l|}
\hline \multicolumn{4}{|c|}{2004} & \multicolumn{4}{c|}{2005} \\
\hline winter & spring & summer & authumn & winter & spring & summer & authumn \\
\hline
\end{tabular}

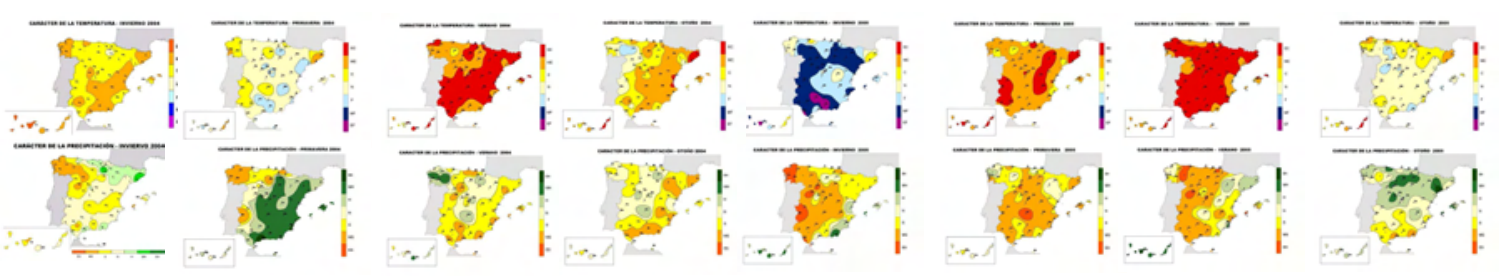

\begin{tabular}{|l|l|l|l|l|l|l|l|}
\hline \multicolumn{4}{|c|}{2006} & \multicolumn{4}{c|}{2007} \\
\hline winter & spring & summer & authumn & winter & spring & summer & authumn \\
\hline
\end{tabular}

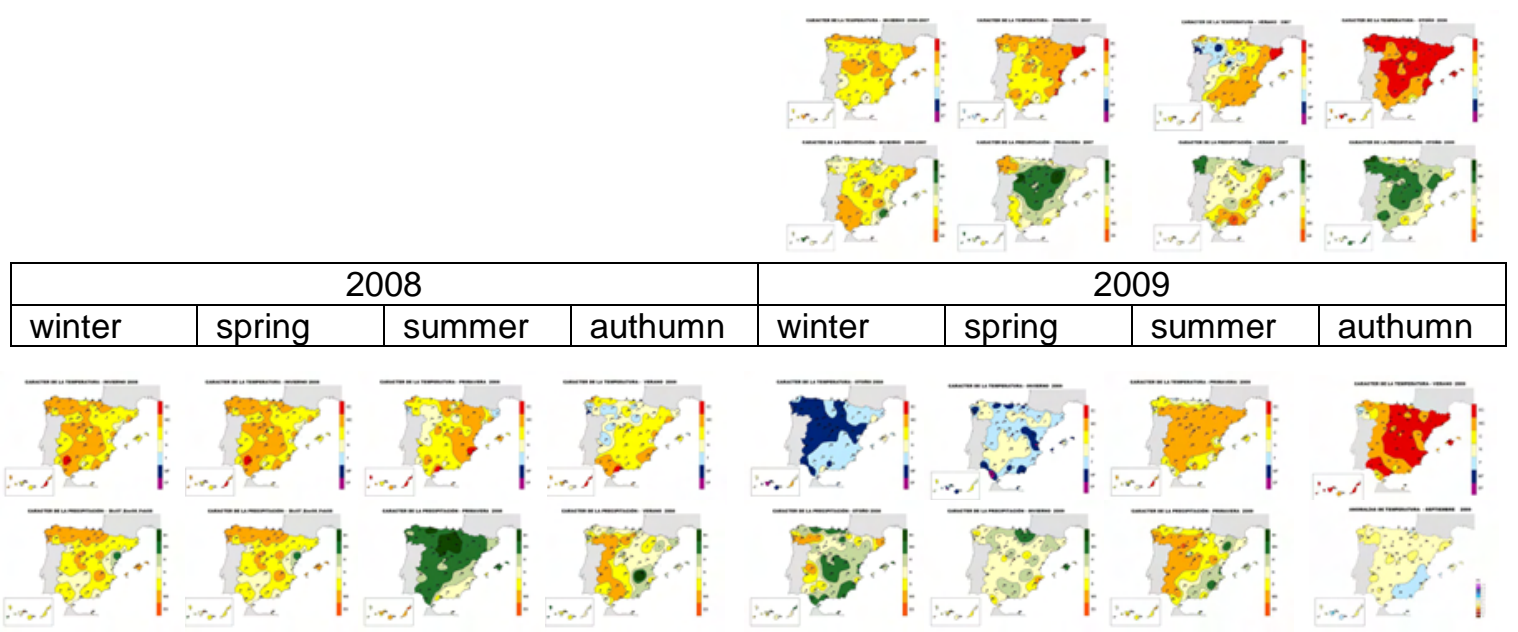

Figure 5.1. Precipitation and temperature records during the time span previous to the imagery used in the study (data provided by the National Weather Institute of Spain (AEMET, Agencia Estatal de Meteorología, Spain), Resumen Anual Climatológico de os años 2004-2009, www.aemet.es).

Extremely wam: The temperatures exceed the maximum recorded for the reference period 1961-1990.

Very warm: The temperatures recorded are within the $20 \%$ of the span of the warmest years of the reference period (1961-1990).

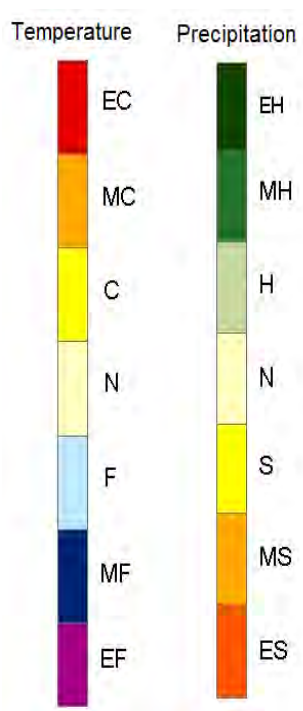

Extremely cold: The temperatures recorded do not reach the

Warm: The temperatures recorded are within $20 \%$ and $40 \%$ of the warmest years reference period 1961-1990.

Normal: The temperatures recorded are within $40 \%$ and $60 \%$ of the reference period.Cold: The temperatures recorded are within $60 \%$ and $80 \%$ of the reference period. Very cold: The temperatures recorded are within the $80 \%$ of the reference period. minimum value recorded during the reference period. 
Figura 5.1. Precipitación y temperatura estacionales durante el periodo de tiempo anterior a las imágenes Hymap disponibles (Agencia Estatal de Meteorología, Resúmenes Estacionales Climatológicos, www.aemet.es).

EC = Extremadamente Cálido: Las temperaturas sobrepasan el valor máximo registrado en el periodo de referencia $1971-2000$.

MC =Muy cálido: $f<20 \%$. Las temperaturas registradas se encuentran en el intervalo correspondiente al 20\% de los años más cálidos.

C = Cálido: $20 \% \leq f<40 \%$.

$\boldsymbol{N}=$ Normal: $40 \% \leq 60 \%$. Las temperaturas registradas se sitúan alrededor de la mediana.

$\boldsymbol{F}=$ Frío: $60 \% \leq f<80 \%$.

MF = Muy Frío: $f \geq 80 \%$.

EF =Extremadamente frío: Las temperaturas no alcanzan el valor mínimo registrado en el periodo de referencia $1971-2000$.

hundred of parameters recorded on weather stations throughout Spain, 2004, 2005 and 2006 are very warm and very dry years, 2006 extremely dry (Weather Agency of Spain, AEMET). The temperature drops to cold in 2007, and the rainfall rate qualifies it as dry. 2008 is a warm year in temperature and neutral on rain rate, recovering very warm temperatures in 2009 and neutral rain rate. In summary, the annual temperature increases from 2008 to 2009 , but the rainfall rate is similar.

The amount of river flow is directly related to the rainfall rate. After the flood in October, washing all efflorescences and crusts on the river flow path, a slow process of water level lowering, leaving wider areas emerged, depends also mainly on temperature and availability of humidity.

The spectral behaviour of the sediments on the river, should respond by the mineralogy of crusts and efflorescences precipitating from the precipitation of acid mine waters to such climate changes. Therefore, main attention has been focused on the spectral features that reveal the changes in the oxidation and hydratation degree of the surfaces.

Where data from 2005 exists, a very warm and extremely dry year, the imagery would witness the maximum effects on oxidation and dehydration on the mineral crusts of the area of study, compared to 2008 and 2009. The aim of this chapter is to determine how this process is experienced on the river and which parameters are critical on its development. 


\subsubsection{IMAGING SPECTROSCOPY ON THE RIVER}

Imaging spectroscopy, using hyperspectral imagery, is the main tool to test the ability to assess contamination parameters on an acid mine drainage environment using remote sensing. This technique, when using reference mineral spectral libraries, has been developed as a useful technique on the geological research on mine waste, enabling quick mineralogical analysis, which saves both time and operational costs compared to traditional sample collection (Swayze, 2000). It also permits the mineralogical analysis of ephemeral and thin crusts concentrating heavy metals on inaccessible surfaces (Plumlee, 1999), providing a very useful tool for environmental evaluation and information.

\subsection{DATASET}

\subsubsection{IMAGERY}

Hymap data were acquired over the Odiel river path in $17^{\text {th }}$ July 2005, $4^{\text {th }}$ August 2008 and $13^{\text {th }}$ August 2009. Hymap is an airborne hyperspectral sensor with 126 wavebands from 436 to $2485 \mathrm{~nm}$ with a spectral resolution of $10-20 \mathrm{~nm}$. Its spatial resolution is 5 $m$ (Table 2.1). The Hymap pre-processing is described in Chapter 2.3. The image processing sequence to provide a map of sediments and contamination on the river is described in Chapters 2.5 and 2.8 .

\subsubsection{FIELD AND LABORATORY SPECTRA}

Field measurements were taken with an ASD FieldSpec 3 Spectrometer (ASD Inc., Boulder, Co, USA) during 2005, 2008 and 2009 campaigns for sensor calibration and thematic purposes. This device measures the ground reflectance spectra covering the wavelength range from $350 \mathrm{~nm}$ to $2500 \mathrm{~nm}$, with coverage, resolutions and operational procedures summarized in Chapters 1.7.2 and 1.7.3.

The entire flow path of the Odiel River was analysed, including 200 field spectra, which were measured in 2005 using an ASD spectrometer, and 600 geologically documented field spectral measurements, which were collected in September 2008, from June 2009 to August 2009, June 2010 and July 2011 for thematic purposes (Riaza and Carrère, 2010). Additionally, 178 selected samples from river sediments were measured in the dark room from 2008 to 2011.

\subsubsection{ADDITIONAL DATA}


Selected representative sediment and rock samples were analysed by X-ray diffraction. Selected samples of river sediments were also collected for conventional mineralogical analysis. The location of the sample in the flood plain was carefully reported to ensure a precise geochemical interpretation of results.

Water samples were also collected contemporaneous to the flights in August 2008 and 2009. Physicochemical parameters such as temperature, $\mathrm{pH}$, specific conductance, electronic conductivity, dissolved oxygen and redox potential were measured in the field. Sulphate anions $\mathrm{SO}_{4}{ }^{2-}$ and concentrations of dissolved $\mathrm{Al}, \mathrm{As}, \mathrm{Ca}, \mathrm{Cd}, \mathrm{Co}, \mathrm{Cr}, \mathrm{Cu}$, $\mathrm{Fe}, \mathrm{K}, \mathrm{Mg}, \mathrm{Mn}, \mathrm{Na}, \mathrm{Ni}, \mathrm{Pb}, \mathrm{Sb}, \mathrm{Se}, \mathrm{Si}, \mathrm{Sn}$ and $\mathrm{Zn}$ were determined by Inductively Coupled Plasma Atomic Emission Spectrometry.

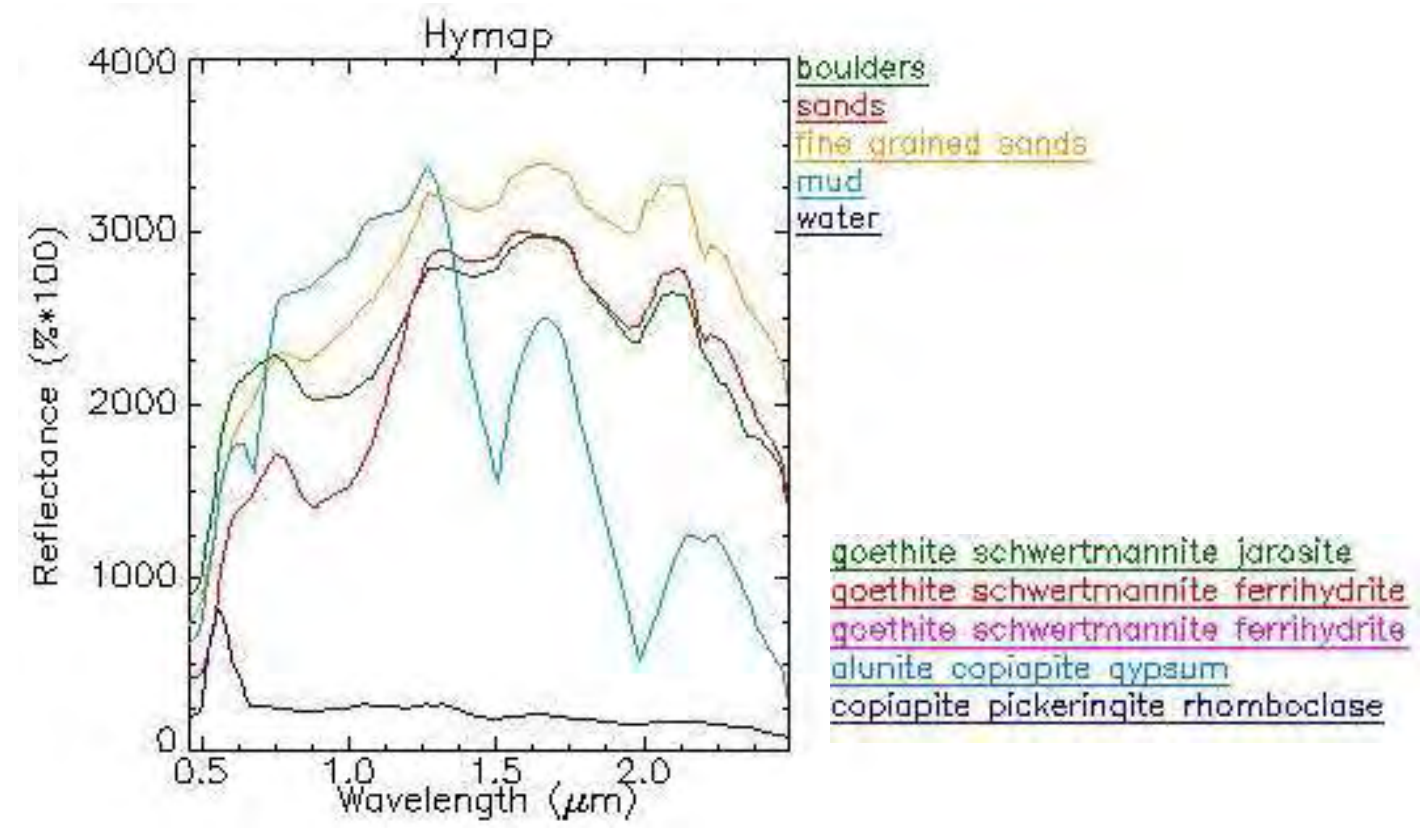

Figure 5.2. Spectra from Hymap imagery from the endmembers used to build the geological map on Figure 2.5D. Right below is the mineralogical diagnosis using the pyrite weathering minerals library as reference (Crowley et al., 2003) for the spectra on the graph.

Figura 5.2. Espectros de las imágenes Hymap en los miembros extremos correspondientes a unidades geológicas utilizados para elaborar el mapa de la figura 2.5D. Abajo a la derecha, leyenda con los diagnósticos mineralógicos con productos de meteorización de piritas realizados con la espectroteca mineral de referencia (Crowley et al., 2003) para los mismos espectros. 


\subsection{SPECTRAL BEHAVIOUR OF MINERAL COATINGS OVER RIVER SEDIMENTS: MAIN TRENDS}

The Hymap images have a spectral response directly related to the grain size of the sediments in the riverbed. Coarse sediments as boulders trend to have a higher overall reflectance in all the wavelength range, while finer sediments, as mud, have a high overall reflectance in the visible and lower in longer wavelengths (Figure 5.2).

Boulders spectra have a shoulder at $760 \mathrm{~nm}$, a wide depression with a low point at 860 $\mathrm{nm}$ up to $1270 \mathrm{~nm}$ and a more horizontal trend with wide depressions in the water absorption bands at $1490 \mathrm{~nm}$ and $1980 \mathrm{~nm}$. It has a decreasing in reflectance from $2130 \mathrm{~nm}$ to the end of the range, with a sharp minimum at $2200 \mathrm{~nm}$.

Sands have a similar trend but with lower overall reflectance. Red ferruginous quartz grains are abundant, and their influence is displayed in a wide concavity from $600 \mathrm{~nm}$ to $760 \mathrm{~nm}$, with a bending point at $670 \mathrm{~nm}$.

Fine grained sands show a smooth bending from $600 \mathrm{~nm}$ to $760 \mathrm{~nm}$. They don't have the $2200 \mathrm{~nm}$ sharp absorption feature and display weak shoulders at $2200 \mathrm{~nm}$ and $2330 \mathrm{~nm}$; these absorptions are supposed to be related to the presence of muscovite. This mineral proceeds from the Aracena Ranges, in the head of the river, and disappears progressively when approaching to the estuary.

In the case of mud, the most striking spectral feature is the presence of an absorption feature at $670 \mathrm{~nm}$ due to the presence of weeds and aquatic vegetation. This feature is present with variable overall reflectance in wet areas and areas close to the edge of water, which have been recently submerged.

The mineralogical diagnosis of the minerals that cover the river sediments was made using the USGS reference spectral library for pyrite weathering products (Crowley et al., 2003; Riaza et al., 2010; Buzzi et al., 2011a). The coatings covering the top of riverbars are identified as goethite (iron hydroxide). Mud has been identified as hydrated iron sulphate (copiapite). Water mapped on Hymap images is diagnosed as copiapite. Therefore, water must be mapped apart from dry or wet land before performing any mineralogical diagnosis. The wrong mineralogical diagnosis of water as copiapite is an example of how careful the mineralogical diagnosis must be, taking the geological context into account. 
Most of the river flow path is contaminated by acid mine drainage precipitates (Chapter 1, Figure 1.2). The spectral response of the detrital materials of clean tributaries and contaminated paths is quite diverse (Figure 5.3). The field spectra of the soil on the Vulcanosedimentary Complex, the geological unit hosting most ore deposits in the Pyrite Belt (Figure 5.3A), show a straight climbing line in the visible. Pebbles and sand on the bottom of the channel show smoothed absorption features related to iron and enhanced narrow absorptions at $2.2 \mu \mathrm{m}$ and weak $2.3 \mu \mathrm{m}$ typical of muscovite (Riaza and Carrère, 2010b). Comparatively, the spectra on the contaminated river Odiel, show enhanced absorptions typical of iron bearing oxi-hydroxides and sulphate and lacking enhanced muscovite features (Figure 5.3B). Such enhanced features permit the spectral isolation of contaminated areas on the flow path, the elaboration of masks to perform detailed image processing, and the availability of suitable subscenes to qualify the mapping of contamination products (Chapter 2).
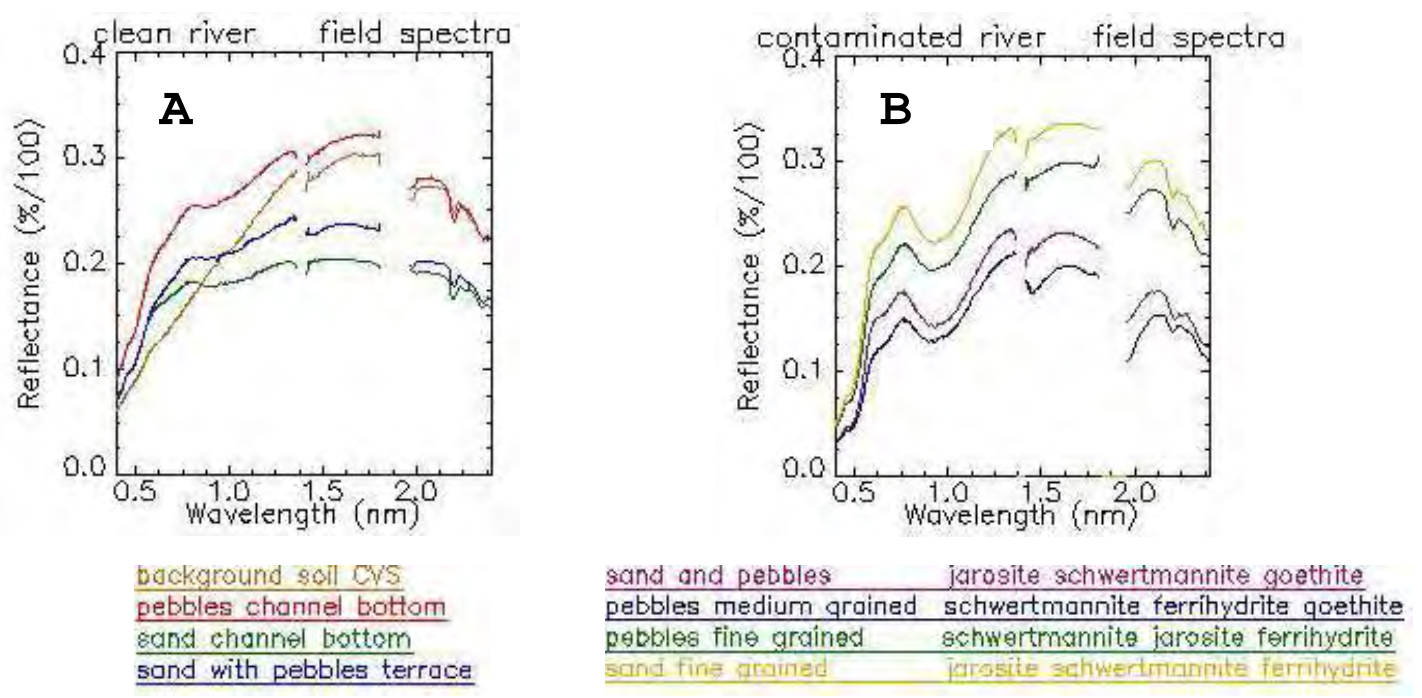

Figure 5.3. Field spectra on detritic materials at the bottom of the channel. A: Tributary to the Odiel River clean from contamination by acid mine drainage precipitates. B:

bottom of the channel detrital materials on the contaminated Odiel River.

Mineralogical diagnose of coatings using a laboratory reference spectral library

(Crowley et al., 2003).

Figura 5.3. Espectros de campo medido en sedimentos detríticos en el fondo del canal del río. A: Sedimentos en un afluente al río Odiel sin contaminación por precipitados de aguas ácidas. B: Sedimentos del fondo del río Odiel contaminados por precipitados de aguas ácidas. Diagnóstico mineralógico de las costras que cubren los sedimentos con la espectroteca de referencia de laboratorio (Crowley et al., 2003). 


\subsection{CHANGE DETECTION OF MINERAL COATINGS OVER SEDIMENTS ALONG}

THE RIVER ODIEL (2005-2008-2009)

Several test sites are selected according to contamination sources and the hydrodynamical setting (Figure 5.4) on the river. The geochemical and geomorphological processes taking place along the river, the geometry of the sediment bodies and the mineralogical changes of the crusts and efflorescence that cover the sediments are described below.
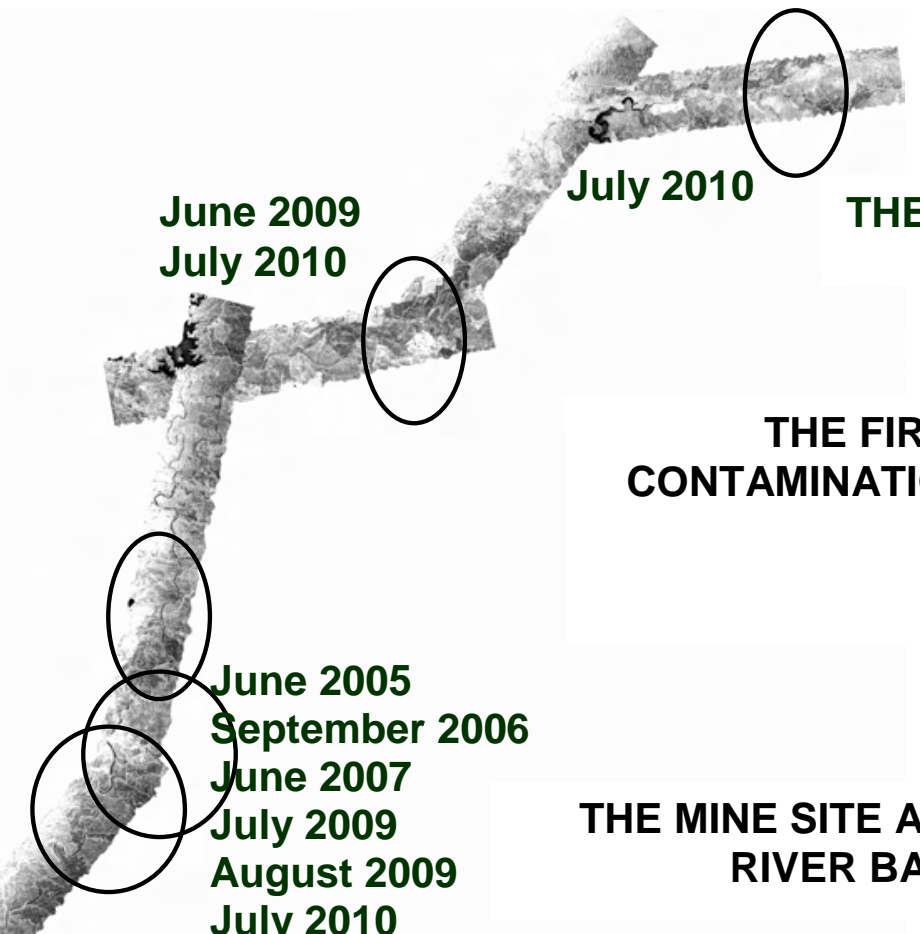

\section{THE MINE SITE ALONG THE RIVER BANK}

\section{September 2008 \\ June 2009 \\ August 2009 \\ July 2010 \\ June 2009 \\ THE ENTRANCE TO THE ESTUARY}

July 2010

Figure 5.4. Mosaic with the ten Hymap flight lines covering the flow path of the Odiel River in 2008, with test sites and locations and dates of field spectra.

Figura 5.4. Mosaico con las diez líneas de vuelo del sensor Hymap que recorren el curso del río Odiel en 2008, con expresión de las zonas de estudio seleccionadas para 
hacer cartografías detalladas, y los puntos y fechas de toma de medidas espectrales en campo.

An independent mapping procedure has been used per test site, aiming to extract the maximum geological information from the spectral response, following the general sequence of algorithms described above (Figure 2.3). The geological units mapped are identified by geomorphological and sedimentological criteria. Later, the spectral response is diagnosed using spectral reference libraries (Crowley et al., 2003), and explained considering the geological setting in the nearby areas and the presence or absence of mine sites on tributaries upstream which may carry contaminating water.

\subsubsection{THE HEAD OF THE RIVER (Campofrío)}

\subsubsection{Geological and geomorphological setting}

The test site is near the head of the river, at the foot of the mountain chain built with acid and basic igneous rocks (Figure 5.5). There are no mine sites upstream, and there are no traces of contamination, either in the water or the river sediments. The water flows on a narrow superficially incised course, seldom leaving open water to view. Green vegetation traces the water flow on Hymap images, drawing smooth meanders adjusted to the lithology.

The fluvial sediments are mainly sands with high contents of micas, such as the rockforming minerals of the granite of the Sierra de Aracena. The small sand bodies deposit on the protected bank downstream of the meander. Also, where the flow path widens, the sand deposits suggest incipient braided systems of poorly developed alternating bars. The hydrodynamic regime of the river in this section does not allow the development of large sandbars, due to the narrow channel and the small amount of sediments mobilised.

The Hymap images show small sandbars on smooth meanders. Since the source of the sediments is igneous rocks, riverbars are sands with high quartz and mica contents, both biotite and muscovite, typical of short transport river sediments with an acid and basic igneous rocks source. Only two geological units are mapped with Hymap data (Figures 5.5A and 5.5B). Only one corresponds to river sediments. The second is the background soil, with a typical straight line in the visible wavelength range of the spectra extracted from the imagery (Figures $5 \cdot 5 \mathrm{C}$ and $5.5 \mathrm{D}$ ). 

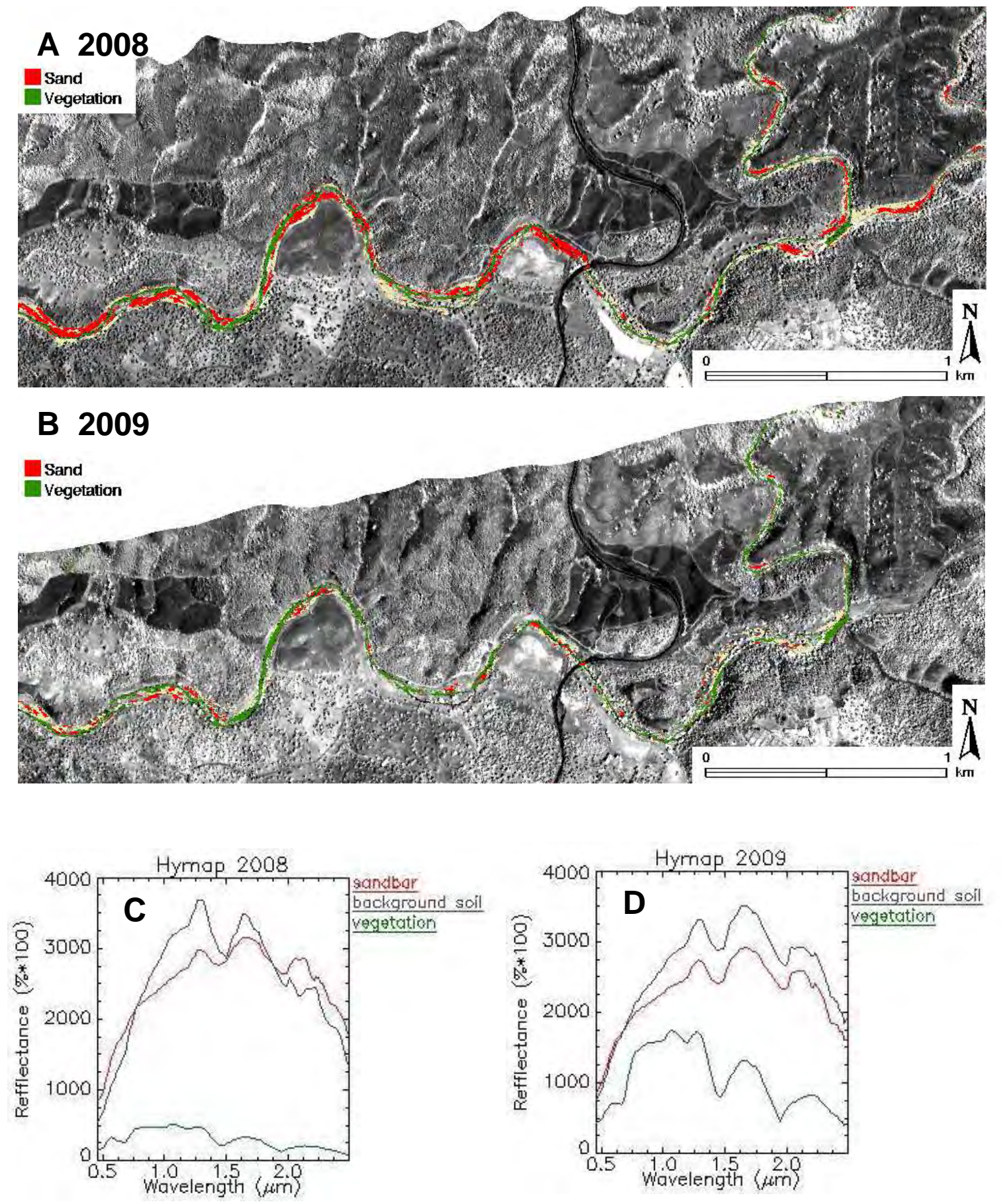

Figure 5.5. The head of the river. A: Map compiled from Hymap images in 2008. B: Map compiled from Hymap images in 2009. C: Hymap spectra from the geological units mapped in 2008. D: Hymap spectra from the geological units mapped in 2009.

Figura 5.5. La cabecera del río. A: Mapa elaborado con imágenes Hymap de 4 de Agosto de 2008. B: Mapa elaborado con imágenes Hymap de 14 de Agosto de 2009. C: Espectros Hymap de las unidades geológicas cartografiadas en 2008. D: Espectros Hymap de las unidades geológicas cartografiadas en 2009. 


\subsubsection{Changes 2008-2009}

Sand covers wider areas along the river path in 2008 than in 2009, and increases their extent downstream. In March and April 2008 there are two episodes of unusually intense rainfalls (Figure 5.6). The level of the water flow in the River Odiel rose, causing floods and spreading sand over the outcrops on the banks of the high flood plain (Figure $5.5 \mathrm{~A}$ ), even close to the head of the river. In contrast, in 2009, sand is restricted to the inner parts of the meanders (Figure $5.5 \mathrm{~B}$ ) due to the customary poor rainfall during the spring.
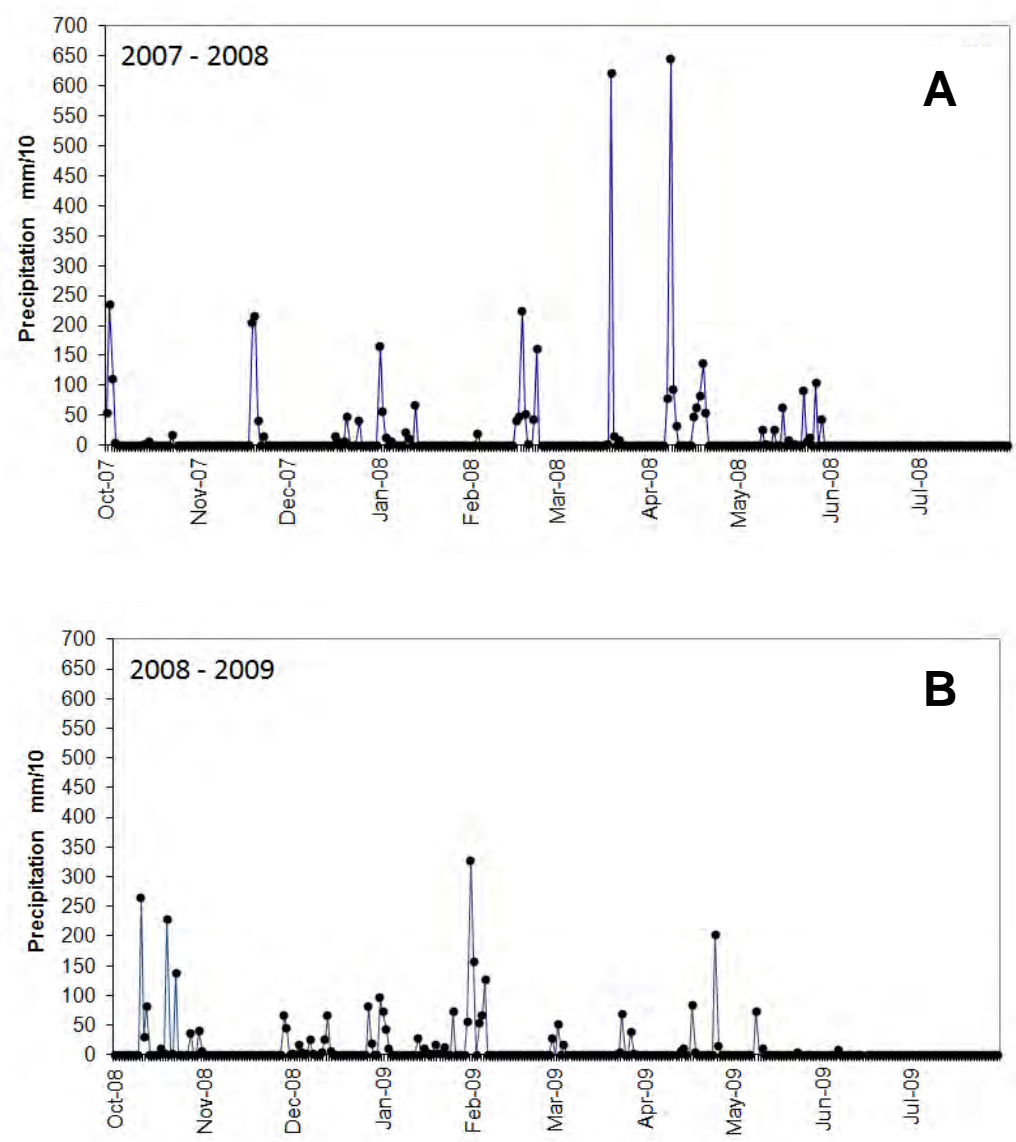

Figure 5.6: Daily rainfall records during the time span previous to the Hymap flights (data provided by the National Weather Institute of Spain (AEMET, Agencia Estatal de Meteorología, Spain, www.aemet.es).

Figura 5.6: Datos diarios de precipitación durante el periodo de tiempo anterior a los vuelos Hymap (Agencia Estatal de Meteorología, www.aemet.es).

\subsubsection{THE FIRST INPUT OF INTENSE CONTAMINATION (Puente de los Cinco Ojos)}

5.4.2.1. Geological and geomorphological setting 
The River Odiel receives contaminated waters coming from the Gossan Dam, which stores copper and iron acid waters at the Rio Tinto mine site and drains to the River
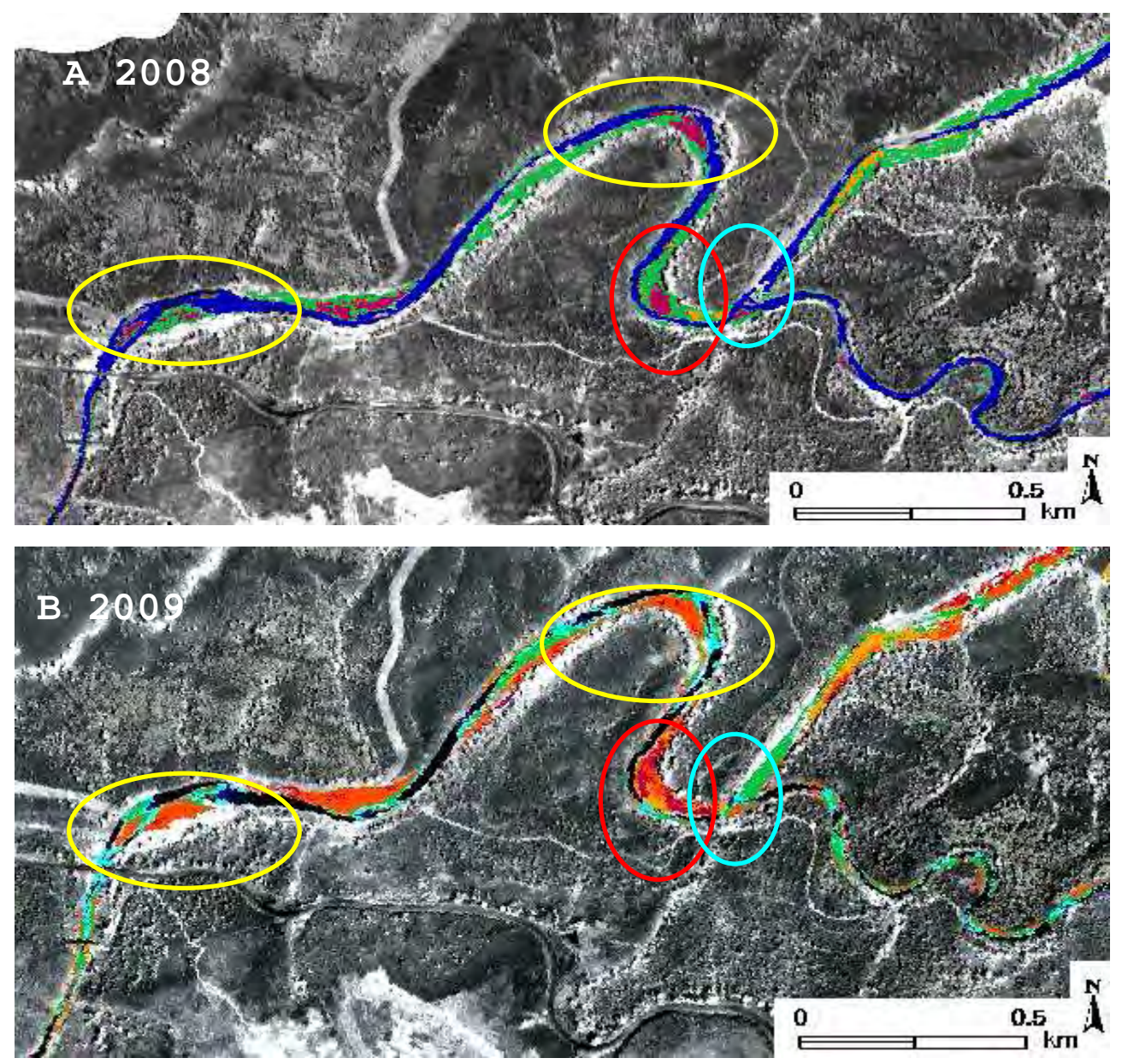

\begin{tabular}{|c|c|}
\hline Hematite & $\mathrm{Fe}_{2} \mathrm{O}_{3}$ \\
\hline Goethite & $\mathrm{FeO}(\mathrm{OH})$ \\
\hline Ferrihydrite & $\mathrm{Fe}^{3+}{ }_{2} \mathrm{O}_{3} \cdot 0.5\left(\mathrm{H}_{2} \mathrm{O}\right)$ \\
\hline Jarosite & $\left(\mathrm{SO}_{4}\right)_{2} \mathrm{KFe}_{3}(\mathrm{OH})_{6}$ \\
\hline Alunite & $\mathrm{KAl}_{3}\left(\mathrm{SO}_{4}\right)_{2}(\mathrm{OH})_{6}$ \\
\hline Gypsum & $\mathrm{SO}_{4} \mathrm{Ca} \cdot 2 \mathrm{H}_{2} \mathrm{O}$ \\
\hline Fibroferrite & $\mathrm{Fe}^{3+}\left(\mathrm{SO}_{4}\right)(\mathrm{OH}) \cdot 5\left(\mathrm{H}_{2} \mathrm{O}\right)$ \\
\hline Epsomite & $\mathrm{MgSO}_{4} \cdot 7\left(\mathrm{H}_{2} \mathrm{O}\right)$ \\
\hline Schwertmannite & $\mathrm{Fe}^{3+} 16 \mathrm{O}_{16}(\mathrm{OH})_{12}\left(\mathrm{SO}_{4}\right)_{2}$ \\
\hline Halotrichite & $\mathrm{Fe}^{2+} \mathrm{Al}_{2}(\mathrm{SO} 4)_{4} \cdot 22\left(\mathrm{H}_{2} \mathrm{O}\right)$ \\
\hline Rhomboclase & $\mathrm{HFe}^{3+}\left(\mathrm{SO}_{4}\right)_{2} \cdot 4\left(\mathrm{H}_{2} \mathrm{O}\right)$ \\
\hline Pickeringite & $\mathrm{MgAl}_{2}\left(\mathrm{SO}_{4}\right)_{4} \cdot 22\left(\mathrm{H}_{2} \mathrm{O}\right)$ \\
\hline Paracoquimbite & $\mathrm{Fe}^{3+}{ }_{2}\left(\mathrm{SO}_{4}\right)_{3} \cdot 9\left(\mathrm{H}_{2} \mathrm{O}\right)$ \\
\hline \multicolumn{2}{|c|}{ Copiapite $\mathrm{Fe}^{2+} \mathrm{Fe}^{3+}{ }_{4}\left(\mathrm{SO}_{4}\right)_{6}(\mathrm{OH})_{2} \cdot 20\left(\mathrm{H}_{2} \mathrm{O}\right)$} \\
\hline Ferricopiapite & $\mathrm{Fe}^{3+}{ }_{0.6666}^{\mathrm{Fe} 3+}{ }_{4}\left(\mathrm{SO}_{4}\right)_{6}(\mathrm{OH})_{2} \cdot 20\left(\mathrm{H}_{2} \mathrm{O}\right)$ \\
\hline Szmolnokite & $\mathrm{Fe}\left(\mathrm{SO}_{4}\right) \cdot \mathrm{H}_{2} \mathrm{O}$ \\
\hline Rozenite & $\mathrm{Fe}^{2+}\left(\mathrm{SO}_{4}\right) \cdot 4\left(\mathrm{H}_{2} \mathrm{O}\right)$ \\
\hline Melanterite & $\mathrm{Fe}^{2+}\left(\mathrm{SO}_{4}\right) \cdot 7\left(\mathrm{H}_{2} \mathrm{O}\right)$ \\
\hline
\end{tabular}

Figure 5.7. The river at the first intense contamination input (Puente de los Cinco Ojos). A: Map of coatings over river sediments compiled from Hymap data on $4^{\text {th }}$ August 2008. B: Map of coatings over river sediments compiled from Hymap data on $13^{\text {th }}$ August 2009. Legend including all minerals of the reference spectral library on minerals associated with iron sulphide mine waste products (Crowley et al., 2003). 
Figura 5.7. El río en el punto del primer aporte intenso de contaminación (Puente de los Cinco Ojos). A: Mapa de costras depositadas sobre los sedimentos del río elaborado con datos Hymap del 4 de Agosto de 2008. B: Mapa de costras depositadas sobre los sedimentos del río elaborado con datos Hymap del 14 de Agosto de 2009. La leyenda incluye los minerales de la espectroteca de referencia de minerales de meteorización de piritas (Crowley et al., 2003).

Odiel by a tributary (Figure $5 \cdot 7 \mathrm{~A}$ ). Because of the main contribution of flow from the Gossan Dam, the geomorphology of the river downstream from the junction with the stream changes, developing wider meanders and larger sandbars. The growth of sulphate crusts and efflorescence covers a comparatively extensive surface from the source of contaminating water. In the summer, only the upper coarse grain sediments of the sandbars show oxidised coatings.

\subsubsection{Changes 2008-2009}

When comparing the Hymap imagery from the $4^{\text {th }}$ August 2008 and $13^{\text {th }}$ August 2009 (Figure 5.7A and Figure 5.7B), the sandbars are in the same position in both years, suggesting a similar water transport capacity during the previous wet season. The water level recedes in 2009 from 2008, exposing large areas covered with fine grained mud to the atmosphere in 2009, experiencing progressive dehydration.

As a consequence of the larger area of exposure of sediments and crusts, the map in 2009 is more detailed than in 2008. This detail is reduced once the geological units identified are mineralogically diagnosed using the Spectral Analyst (Riaza et al., 2012a), which forces merging on larger and fewer geological units (Figure $5 \cdot 7 \mathrm{C}$ and $5 \cdot 7 \mathrm{D})$.

On riverbars, only the boulders on the top are oxidised to goethite in 2008, wrapped by schwertmannite ribbons over finer grained fluvial deposits (Figure $5.7 \mathrm{~A}$ and $5.7 \mathrm{~B}$, red circle). Riverbars are comparatively more oxidised in 2009. Schwertmannite along fine grained sands is comparatively reduced in 2009.

The 2009 map on the riverbars shows finer detail on the oxidation state of the boulders and sands, revealing indications of areas formerly flooded in the year, traced by a progressively less oxidised mineral diagnosis approaching the water (Figure 5.7D).

Grain size also decreases towards the water. Both parameters evolve together and cannot be separated on this map. 
The 2009 map also draws thin fringes of hydrated sulphate crusts along straight line water edges, which are not obvious on the 2008 map (Figures 5.7A and Figure 5.7B, yellow circle). Large areas of hydrated sulphate are mapped at the junction of the contaminated tributary and the River Odiel (Figure $5.7 \mathrm{~B}$, cyan circle), where schwertmannite widely covers the bottom of the river path extending upstream along the main course of the River Odiel. These give evidence of past intense water flow along the tributary from the Gossan Dam, which upstream invades the main course of the River Odiel, and precipitates abundant schwertmannite.
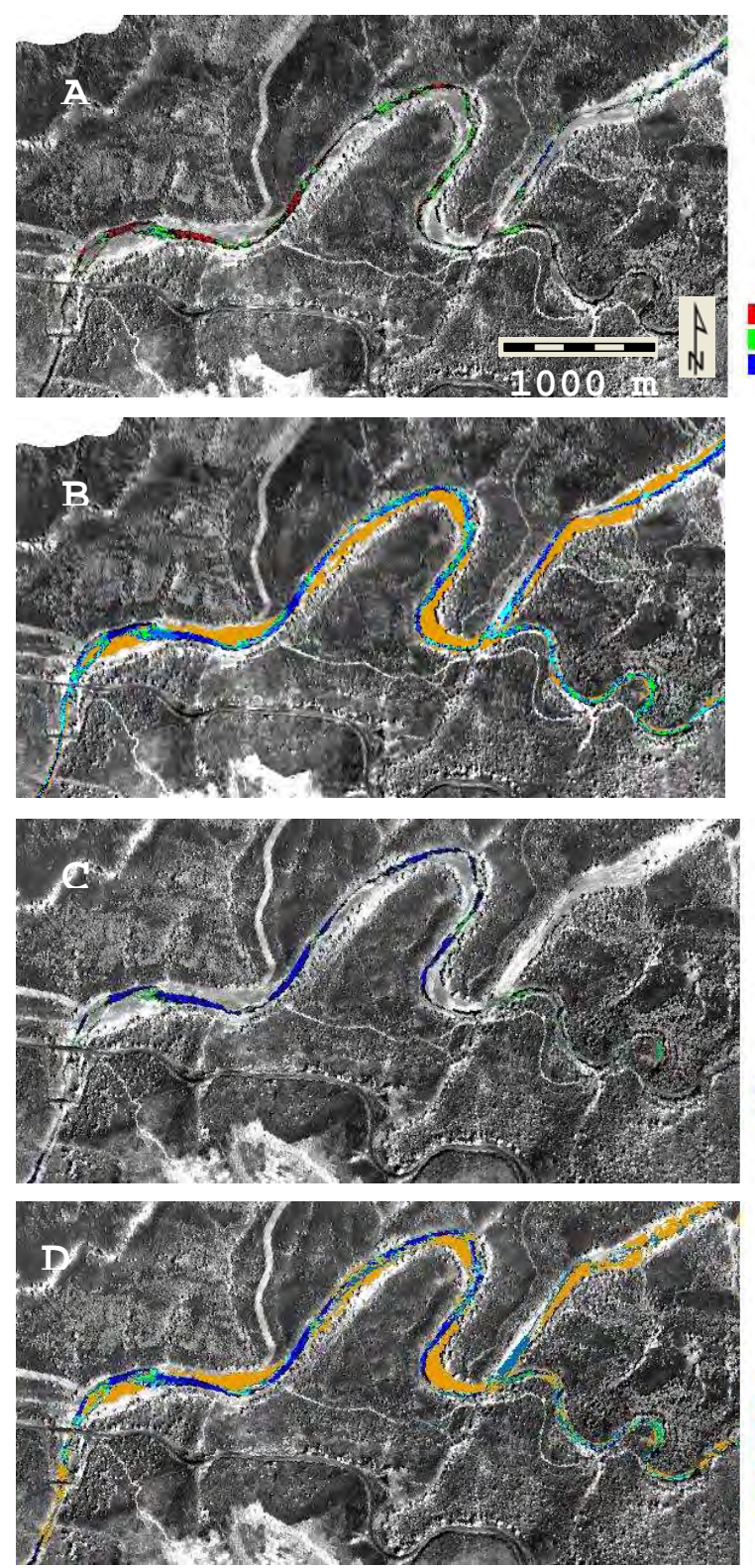

2008

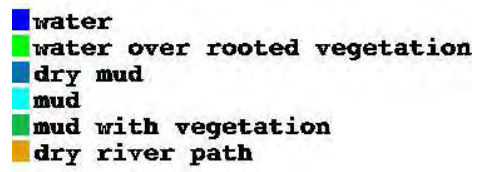

2009

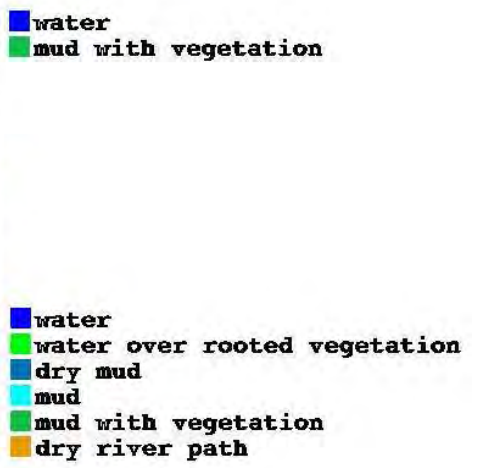

Figure 5.8. The first input of intensely contaminated water in the river (Puente de los Cinco Ojos). A: Map of deep water with different $\mathrm{pH}$ built from Hymap data on the $4^{\text {th }}$ August 2008. B: Map of water and mud from Hymap data on the $4^{\text {th }}$ August 2008. C: Map of deep water built from Hymap data on the $13^{\text {th }}$ August 2009. D: Map of water and mud built from Hymap data on the $13^{\text {th }}$ August 2009. 
Figure 5.8. El río en el punto del primer aporte intenso de contaminación (Puente de los Cinco Ojos). A: Mapa de agua profunda con distinto $\mathrm{pH}$ elaborado con datos Hymap del 4 de agosto de 2008. B: Mapa de agua y barro elaborado con datos Hymap del 4 de Agosto de 2008. C: Mapa de agua profunda elaborado con imágenes Hymap del 13 de Agosto de 2008. D: Datos de agua y barro elaborado con datos Hymap del 13 de Agosto de 2009.

\subsubsection{Mapping water $\mathrm{pH}$ with Hymap data}

Upstream from the Bridge of the Five Arches, the uncontaminated river Odiel receives the heavily contaminated water from the Gossan dam of the mine facilities of the Rio Tinto mine site, producing and abrupt decrease of $\mathrm{pH}$ from 6-7 to 3.

Once a map identifying the areas where the presence of vegetation and the bottom of the river influences the spectral response, it is possible to face the challenge of identifying the spectral features associated to the influence of the $\mathrm{pH}$ of the water (Figure 5.8A and Figure 5.8B).

Hymap 2008 images are able to produce maps of $\mathrm{pH}$ when only deep water is introduced in the sequence of mapping algorithms (Figure 5.8A). The spectra on water with more basic $\mathrm{pH} 6$ of uncontaminated water upstream from the confluence with the tributary with intensely contaminated water displays higher overall reflectance with a maximum at $0.63 \mu \mathrm{m}$ and descending reflectance towards longer wavelengths until 1 $\mu \mathrm{m}$, agreeing with the trends on the spectral response of deep basic water near the estuary (Figure 5.9A). Intermediate acidic water downstream with $\mathrm{pH} 3$ display spectra with lower overall reflectance, and the same $0.63 \mu \mathrm{m}$ peak, narrowing on a quick descent to $0.67 \mu \mathrm{m}$, where reflectance descends less steeply.

The more acidic water ( $\mathrm{pH}$ 3) shows spectra with low overall reflectance and clear influence of vegetation. This more acidic water restricts to partially dammed areas in the river with lower energy water flow and tendency to host vegetation (Figure 5.8B).

These abrupt changes on $\mathrm{pH}$ happen on water pooled behind small rock fragments on the river at distances within centimetres. 


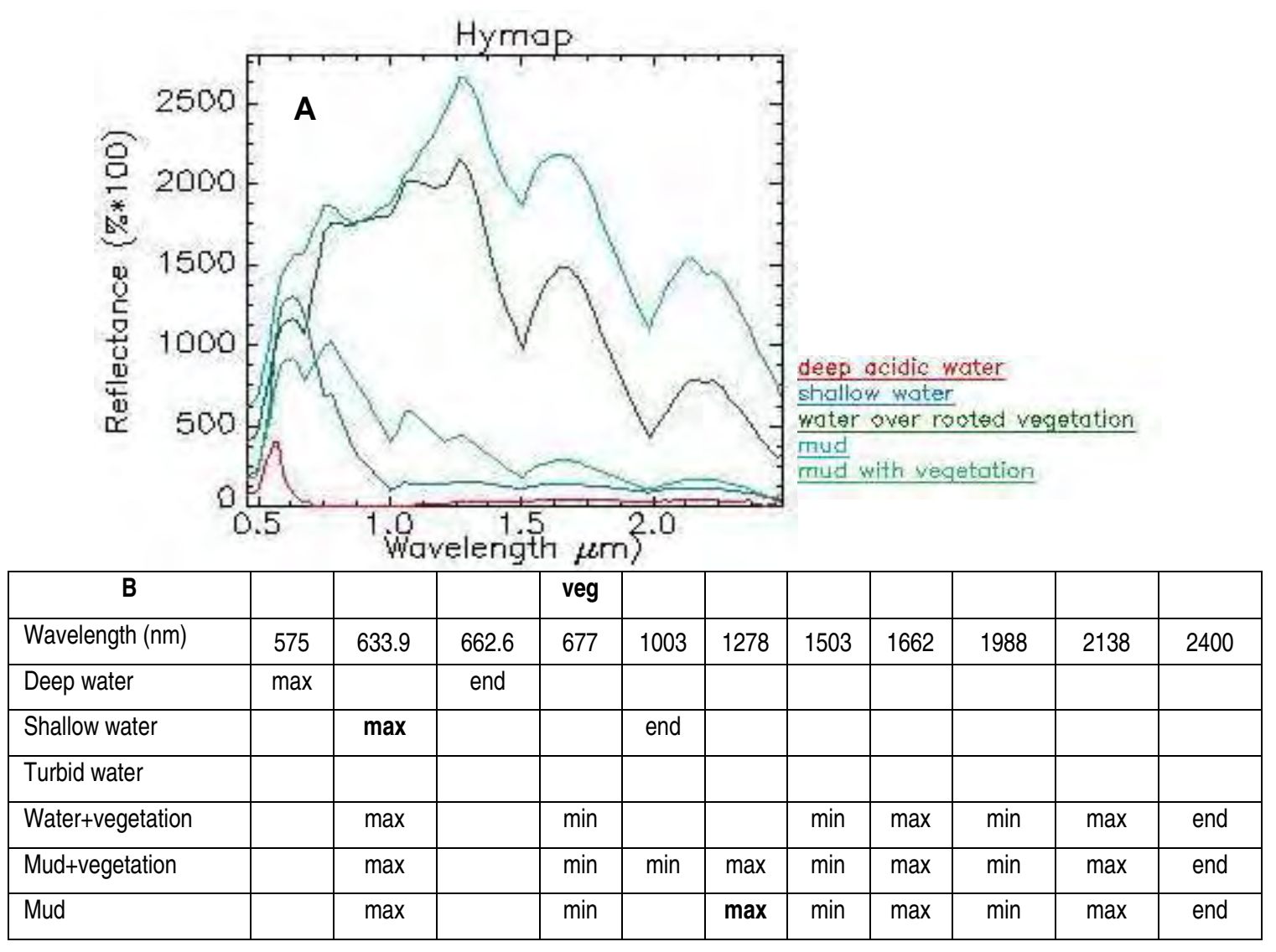

Figure 5.9. A. Hymap spectra of the endmembers used to build the map of water and mud (Figure 5.8B). B. Table summarizing relevant spectral features on the spectra above.

Figura 5.9. Espectros de imágenes Hymap de los miembros extremos usados para elaborar el mapa de agua y barro (Figura 5.8B). B: Tabla que resume los rasgos espectrales más importantes de los espectros anteriores.

\subsubsection{BRIDGE IN THE CALAÑAS-VALVERDE DEL CAMINO ROAD}

5.4.3.1. Geological and geomorphological setting.

This section of the river (Figure 5.10) is quite straight and it has a high hydrodynamic regime, which limits the development of riverbars. Consequently these fluvial sediments are not so well developed as in other sections of the river Odiel. Moderately well developed rivebars and narrow terraces sediment along the flow path. The narrow terraces appear in upper borders of the flow path along the straight sections of the river.

In this section there are no mine workings in the surroundings, but the river is still carrying contaminated waters from upstream. There are several natural and artificial 
walls crossing the river that influence the hydrodinamic regime of the river storing water. The riverbars are better developed in the north of the studied section than in the south. Nevertheless, the overall development of riverbars is moderated when compared with other parts of the river.
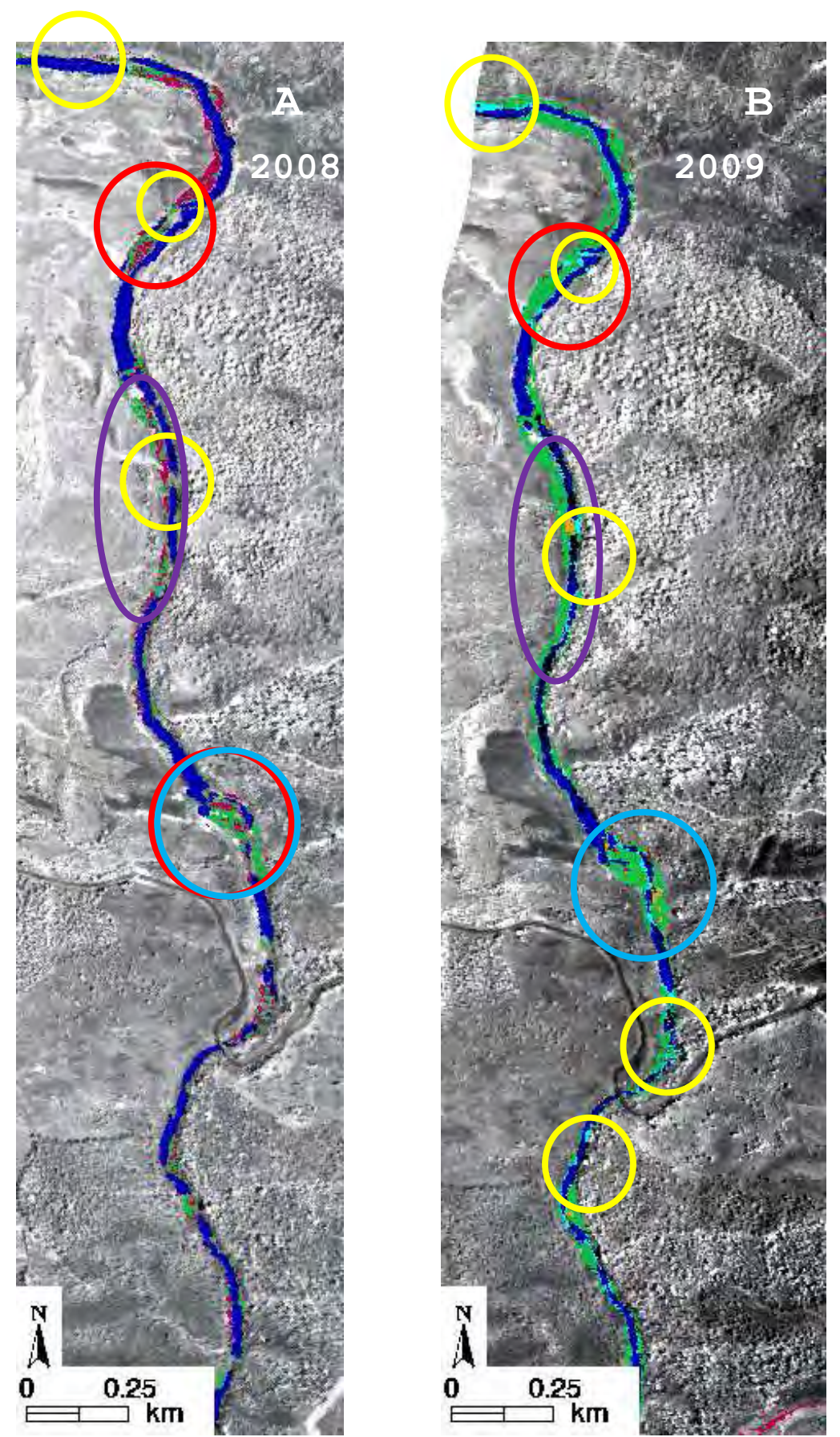

Figure 5.10. Bridge on the road Calañas-Valverde del Camino. Maps of coatings over river sediments diagnosed with the reference spectral library (Crowley et al., 2003). Legend as Figure 5.7. A: Map of coatings over river sediments compiled from Hymap data in 2008. B: Map of coatings over river sediments compiled from Hymap data in 2009. 
Figura 5.10. Puente sobre el río Odiel en la carretera Calañas-Valverde del Camino. Mapas de costras precipitadas sobre sedimentos fluviales diagnosticados mineralógicamente con la espectroteca de referencia (Crowley et al., 2003). Leyenda según la Figura 5.7. A: Mapa de costras sobre sedimentos fluviales elaborados con imágenes Hymap de 4 de Agosto de 20o8. B: Mapa de costras sobre sedimentos fluviales elaborados con imágenes Hymap de 13 de Agosto de 2009.

The geometry of riverbars from 2008 to 2009 is very similar. As on previous sections, the main differences are caused by changes on the water level and the degree of oxidation of the coatings over the sediments.

\subsubsection{Changes 2008-2009}

As observed at the Puente de los Cinco Ojos, the water level is higher in 2008 than in 2009 (Figures 5.10A and 5.10B). As a consequence, there are wider areas covered with hydrated sulphate in 2009 than in 2008, mainly schwertmannite, and copiapite on the wetter spots (Figure 10B, blue circle). The riverbars show oxidized spots in 2008 absent in 2009 (Figures 5.10A and 5.10B, red circles). Also, riverbars are more oxidized in 2008 than in 2009, showing goethite on the coatings in 2008, which is replaced by schwertmannite in 2009.

The descent in the water level from 2008 to 2009 exposes to the atmosphere areas that were under water in 2008. This favours the development of wider areas covered by hydrated sulphate in 2009. The mineralogical diagnosis confirms this trend. In 2008 the riverbars are covered mainly by goethite and surrounding stripes of schwertmannite, while in 2009 the same riverbars appear covered by schwertmannite and occasionally goethite on top of bars. In 2009, the coatings of hydrated sulphate (copiapite) surrounding riverbars are more abundant than in 2008, and some narrow parts of the frequently flooded riverpath are also covered by copiapite (Figure 5.10B, yellow circles).

In the neighbourhood of the bridge that crosses the road from Calañas to Zalamea there is an outcrop of hard rocks interstratified within the Vulcano Sedimentary Complex (Figure 5.10A, blue circle). It works as a natural dam that retains water and influences the geochemical evolution of the minerals precipitated downstream. Sediments are covered by oxidized minerals in 2008, while in 2009 there are wide both oxidized surfaces and areas with hydrated minerals covering the borders of channels (Figure 5.10A and 5.10B, blue circles). 
The narrow terraces along the upper borders of the river path in the zones with a straight channel are covered by coatings of oxidized minerals, such as goethite, in 2008 (Figure 5.10A, purple circle). In contrast, in 2009 the mineral of the coatings covering terraces are diagnosed as schwertmannite (Figure 5.10B, purple circle).

\subsubsection{THE MINESITE WORKS IN THE MIDDLE COURSE (Sotiel)}

\subsubsection{Geological and geomorphological setting}

The mine site of Sotiel is located at the mid course of the river, at the beginning of the meandering with larger development of riverbars. The mine works of Sotiel are evident along the river, with large dumps, tailings and ponds. The mine works used the river as a washing system, building numerous walls along the area where mine dumps occur. As a consequence, the river flow is artificially slowed and water is pooled.

The northern part of the studied section has a narrow river path, and fluvial sediments are not well developed, mainly in small marginal riverbars. From the confluence of the River Odiel with a stream flowing from the NE, the river path is wider and fluvial sediments are better developed. River bars deposit on meanders and behind knick points.

The summer of 2005 was extremely dry and warm (Figure 5.1), compared to a very warm 2008 and slightly warmer 2009, with regular humidity in both cases. The development of precipitates over the river should respond to high oxidation in 2005 and comparatively larger areas of hydrated mineralogical phases in 2008 and 2009.

\subsubsection{Changes 2005-2008-2009}

As expected, according to rainfall rates in spring and average rainfall and temperature on the seasons previous to the flight, the level of the water in 2005 is lower than in 2008 and 2009. In spite of the comparatively heavy rains in the spring of 2008, the water is level in 2008 and 2009 at this point. The numerous walls crossing the river slow down the water flow and reduce the differences caused by changes in climate. Only extremely poor rainfall and high temperatures in 2005 show an obvious decrease in water flow in this section. 
The summer of 2005 was very warm and dry, following an already warm and dry year in general. The water level is low, and the general pattern of the mineralogical coatings of the sediments on the river is intensely oxidised (Figure 5.11A).

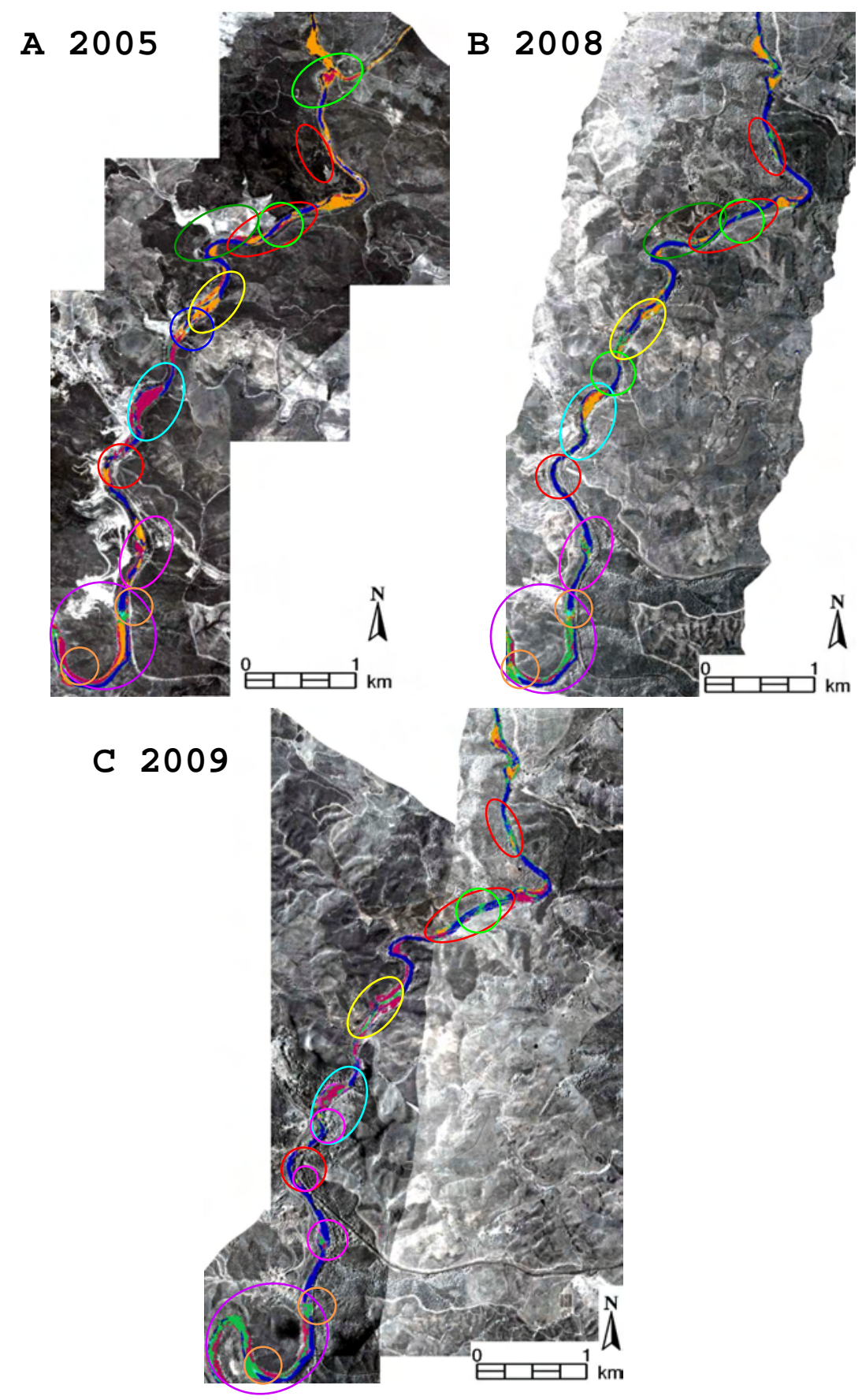

Figure 5.11. The mine site works in the middle course (Sotiel). Maps of coatings over river sediments diagnosed with the reference spectral library (Crowley et al., 2003). Legend as Figure 5.7. A: Map of coatings over river sediments compiled from Hymap data in 2005. B: Map of coatings over river sediments compiled from Hymap data in 2008. C: Map of coatings over river sediments compiled from Hymap data in 2009. 
Figura 5.11. Las escombreras de las minas en el curso medio a orillas del río Odiel (Sotiel). Mapas de costras precipitadas sobre sedimentos fluviales diagnosticados mineralógicamente con la espectroteca de referencia (Crowley et al., 2003). Leyenda según la Figura 5.7. A: Mapa de costras sobre sedimentos fluviales de 17 de Junio de 2005. B: Mapa de costras sobre sedimentos fluviales de 4 de Agosto de 2008. C: Mapa de costras sobre sedimentos fluviales de 13 de Agosto de 2009.

The main riverbars are located in the same positions from 2005 to 2009. This proves that there are no significant changes in the hydrodynamic regime of the river in this area. Larger areas are exposed to the atmosphere (Figure 5.11A, Figure 5.11B andFigure 5.11C, red circles) in 2005 compared to 2008 and 2009.

In 2005 (Figure 5.11A), the river sediments of the northern part of the studied area are mainly covered by oxidised minerals, mainly jarosite and goethite (Figure 5.11A, green circles). Jarosite covers most of riverbars, while goethite is located on top of riverbars. Eventually there is schwertmannite in the edge of the riverbars and small crusts of copiapite associated with mud surfaces located in the edges and borders of some riverbars (Figure 5.11A, blue circle).

The main dump of the Sotiel mine (Figure 5.11A, dark green circle) is a strong source of contamination that locally affects the sediments downstream, resulting in an increase in oxidised mineralogical phases, mainly goethite. Immediately downstream from the main dump, there are jarosite-covered riverbars with sparse goethite tops and wrapping copiapite-covered narrow mud fringes (Figure 5.11A, yellow circle). Further downstream there is a large river bar covered widely by goethite coatings, wrapped by thin ribbons of schwertmannite (Figure 5.11A, cyan circle).

Downstream from the main dump on the bank of the river, the riverbars are coated by jarosite externally surrounded by goethite (Figure 5.11A, magenta circle). Also, copiapite covers wider areas behind knick points on the river (Figure 5.11A, orange circles) than upstream. In the riverbars of the southern meander (Figure 5.11A, purple circle), the previous trend changes, and goethite is more abundant and covers most of the riverbars, restricting the extension of jarosite to the borders. Schwertmannite is also more abundant, concentrated on the muddy areas at the intersections of alternating riverbars, acting as smooth knick points and slowing the water flow.

The alternation of schwertmannite and goethite on the borders of riverbars provide evidence of the variations in the time span from high waters and the intensity of oxidation. A goethite ribbon means stronger oxidation; therefore a longer time since 
the area was flooded by water. If schwertmannite ribbons wrap the riverbars, the areas have been more recently abandoned by water. The presence of goethite external wrappings on the riverbars of the middle of the section suggest that the water level was lower for a longer time than upstream or downstream, likely due to the influence of the numerous watermills crossing the river which change the natural speed of the water flow.

\subsection{The year 2008}

The summer of 2008 followed a wet and relatively warm spring, causing floods. The level of water is the highest of the three years followed, and the general expected mineralogical coatings are the most hydrated from the three years under observation.

In the northern part of the section, the river bars are mainly covered by jarosite in 2008 (Figure 5.11B), as much as in 2005. However, ribbons of hydrated minerals, such as schwertmannite (Figure 5.11B, green circles) are displayed along the riverside. The goethite on top of jarosite-covered riverbars wrapped by schwertmannite in 2005 is absent in 2008.

In the middle part of the section, jarosite covers wide homogeneous parts of riverbars, while goethite is restricted to the borders of the largest riverbars. Interestingly, copiapite is absent (Figure 5.11B, yellow circle). Copiapite occurs in 2005 in areas which are flooded in 2008. The river bar mainly covered by goethite in 2005 is covered by jarosite in 2008, encased by ribbons of goethite and schwertmannite (Figure 5.11B, cyan circle). Schwertmannite coatings are more extensive in 2008 than in 2005 (Figure $5.11 \mathrm{~B}$, magenta circle) in the southern meander. On the areas with a wider development of hydrated mineralogical phases behind knick points, copiapite occurs in the plugs of the main bars downstream of the series of dams in the southern part in 2008 (Figure $5.11 \mathrm{~B}$, orange circle), and has a slightly wider development than in 2005.

\subsection{The year 2009}

2009 was a slightly warmer and drier summer than 2008 (Figure 5.1). The generalised reduction in the water level along the River Odiel compared to 2008 is visible in the appearance of mud surfaces covered by schwertmannite, that in 2008 were covered by water (Figure 5.11C, yellow circle). The rainfall events of the autumn and winter of 2008 (Figure 5.6) resulted in the wide coverage in the summer of 2009 of hydrated mineral coatings. In the northern part, the borders of the river path flooded in 2008 are 
mainly covered by schwertmannite in 2009, while the main riverbars are covered by jarosite and goethite (Figure $5.11 \mathrm{C}$, green circles).

Downstream from the main mine dump (Figure 5.11A, dark green circle) there is more intense oxidation, shown by the generalised goethite coverings of the riverbars, in contrast with the less oxidised jarosite coatings of 2005 and 2008 (Figure 5.11A, Figure 5.11B and Figure 5.11C, yellow and cyan circles). These goethite-covered riverbars are surrounded by schwertmannite stripes. Intensely hydrated mineralogical phases occur around the oxidised riverbars, as small patches of fibroferrite and pickeringite (Figure $5.11 \mathrm{C}$, magenta circles), on the wet surfaces that emerged since 2008 where hydrated sulphates precipitate.

The riverbars of the southern meander (Figure 5.11C, purple circle) are mainly covered by schwertmannite, with borders of copiapite (Figure $5.11 \mathrm{C}$, orange circles) and tops of goethite. There is also copiapite at the knick points between alternating lingoidal riverbars.

\subsection{Summary of changes 2005-2008-2009}

The summer of the very warm and dry 2005 offers the most oxidised association of precipitates from acid mine drainage contaminated water in the River Odiel, evolving mineralogically with the distance from the large dumps providing the source of strong contamination. In the northern part of the image, the riverbars are mainly covered by jarosite in 2005 with tops of goethite. Schwertmannite is almost absent in this section.

This pattern changes downstream, and goethite, jarosite and schwertmannite cover the riverbars, in addition to copiapite on small wet surfaces. In 2008 the degree of oxidation is lower in the summer because of a previous humid spring with intense rain events and higher water level, and the dominant mineralogical phases on the coatings are jarosite and schwertmannite. Goethite surfaces are scarce in the north, increasing their presence downstream.

In 2009, warmer than 2008 with lower water level, the minerals covering the river sediments are slightly more oxidised, with a wider presence of goethite on top of the riverbars. There are also hydrated minerals covering small muddy surfaces greater than in 2008, which would be then flooded. 


\subsubsection{THE TYPICAL KNICK-POINT PATTERN (WALL SOUTH OF THE MINE OF SOTIEL)}

\subsubsection{Geological and geomorphological setting}

Downstream from the minesite of Sotiel along the river Odiel, there is wall with wide development of coatings of hydrated sulphate, precipitating from oxygenated acid waters by turbulences over the wall. The wall is located at the entrance of a pronounced meander with wide riverbars displaying well grainselected zoning. This location is particularly sensitive to the geochemical evolution of the acid mine drainage products through time, due both to the extension and stability of riverbars and to the proximity to the heavy contamination source of the Sotiel-Almagrera mine site.

\subsubsection{Changes 2005-2008-2009}

\subsection{The year 2005}

In 2005 the northern riverbars are covered mainly by jarosite with tops of goethite, with schwertmannite coatings covering the areas recently abandoned by water (Figure 5.12A, green circle) and copiapite on the small wetter surfaces (Figure 5.12A, yellow circles). The changes in the water level of the river are better shown in the northern (Figure 5.12A, Figure 5.12B and Figure 5.12C, red circles). Wide areas emerged in the dry 2005, are flooded in the humid 2008 and 2009 years. Along the inner limits of the riverbars, narrow stripes of the oxidated mineralogical phase ferrihydrite occur (Figure 5.12A, blue circles) in 2005, the driest year, absent in 2008 and 2009.

The jarosite covering most of the top of the northern riverbars is progressively replaced downstream by goethite, which finally covers most of the riverbar, with narrow jarosite wrappings. The outer borders of the riverbar that are in contact with water remain covered by narrow schwertmannite fringes.

\subsection{The year 2008}

The intense rainfall in spring 2008 resulted on high water level in the summer, and a receding in the oxidation stage of the sulphate covering the riverbars. Some riverbars emerged in 2005 are flooded in 2008 (Figure 5.12A and Figure 5.12B, red circles). Many areas emerged in 2005 are now under water. The descent in the general stage of oxidation can be seen in the riverbars of the area, which in 2005 were mainly covered 
by jarosite with tops of goethite, and in 2008 are mainly covered by schwertmannite (Figure 5.12A and Figure 5.12B, green circle).
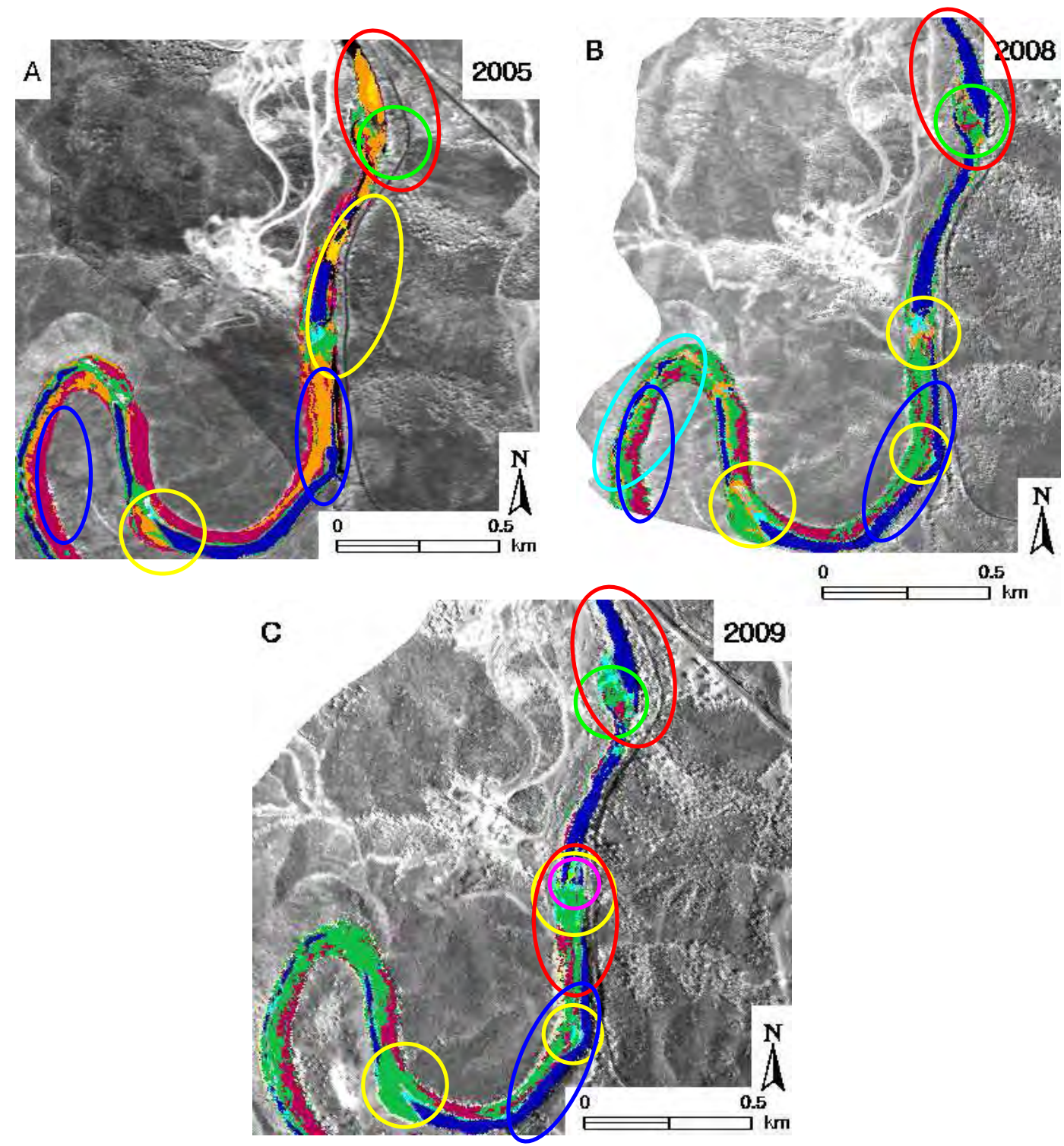

Figure 5.12. The typical knick-point pattern (Wall south of Sotiel). Maps of coatings over river sediments diagnosed with the reference spectral library (Crowley et al., 2003). Legend as Figure 5.7. A: Map of coatings over river sediments compiled from Hymap data in 2005. B: Map of coatings over river sediments compiled from Hymap data in 2008. C: Map of coatings over river sediments compiled from Hymap data in 2009.

Figura 5.12. El ejemplo típico de ruptura de pendiente (presa al sur de Sotiel). Mapas de costras precipitadas sobre sedimentos fluviales diagnosticados mineralógicamente con la espectroteca de referencia (Crowley et al., 2003). Leyenda según la Figura 5.7. A: Mapa de costras sobre sedimentos fluviales elaborado con imágenes Hymap de 17 de Junio de 2005. B: Mapa de costras sobre sedimentos fluviales elaborado con imágenes Hymap de 4 de Agosto de 20o8. C: Mapa de costras sobre sedimentos fluviales elaborado con imágenes Hymap de 13 de Agosto de 2009. 
In 2008 there is still some jarosite surrounding the riverbars, but the borders of ferrihydrite do not occur (Figure 5.12B, blue circle). As in 2005, most of the hydrated sulphate, as copiapite, display on the muddy and wet borders of the riverbars (Figure $5.12 \mathrm{~A}$ and 5.12B, yellow circles). The complete sequential zoning of mineralogical phases representing progressive oxidation, ranging from copiapite in the wetter parts of riverbars, and moving through jarosite, schwertmannite and goethite towards the banks of the river (Figure 5.12B, cyan circle) is displayed in the southernmost meander.

\subsection{The year 2009}

2009 was a very warm year with a normal humidity (Figure 5.1), and the water level recedes from 2008. As a result, some small areas flooded in 2008 are exposed again to the atmosphere (Figure 5.12C, red circles). The moderately more humid climate in 2009 than 2008 does not increase dramatically the oxidation of coatings as in 2005. Jarosite present in 2008 (Figure 5.12B, green and yellow circles) disappear in 2009 (Figure 5.12C, green and yellow circles) replaced by schwertmannite and copiapite.

In contrast, goethite and schwertmannite keep their extension in 2009 compared to 2008 (Figure 5.12B and 5.12C, blue circles). The riverbars appear mainly covered by schwertmannite in 2009 and small stripes of copiapite locate in the same emerged zones than in 2008 (Figure 5.12B and Figure 5.12C, yellow circles). Other highly hydrated minerals, as pickeringite, occur in the muddy and wet areas in 2009, absent in 2008 (Figure 5.12C, magenta circles).

\subsection{Summary of changes 2005-2008-2009}

In 2005, a very dry and very warm year, the river sediments are mainly covered in the summer by jarosite, which is progressively replaced by goethite downstream. Schwertmannite crusts are scarce in the north and gains extension southwards, covering wet zones along with copiapite. The water level of the river increases in the warm and regular humidity 2008, and some riverbars emerged in 2005 are flooded. Intense rainfall isolated events in spring have a strong influence on the high water level of the river and sediment pattern in the summer. Schwertmannite coatings cover wide uniform areas over the riverbars. In 2009, a very warm and regular humidity year, the general pattern of mineralogical phases is similar to 2008. It is remarkable an increased variety of hydrated minerals on the small wetter areas behind knick points, and occasional occurrence of more hydrated mineralogical phases than in 2008. 


\subsubsection{THE LINEAR ENCASED RIVER PATH (FUENTE DE LA CORCHA)}

\subsubsection{Geological and geomorphological setting}

This section of the river has $4.3 \mathrm{~km}$ length and a sinuosity factor of 1.08 (Figure 5.13). The fluvial sediments in this section are coarser than on the rest of the river. The riverpath is a straight line (Figure 5.13), favouring fast water flow and high energy level of the water, able to transport coarser sediments. Riverbars with coarse boulders (over
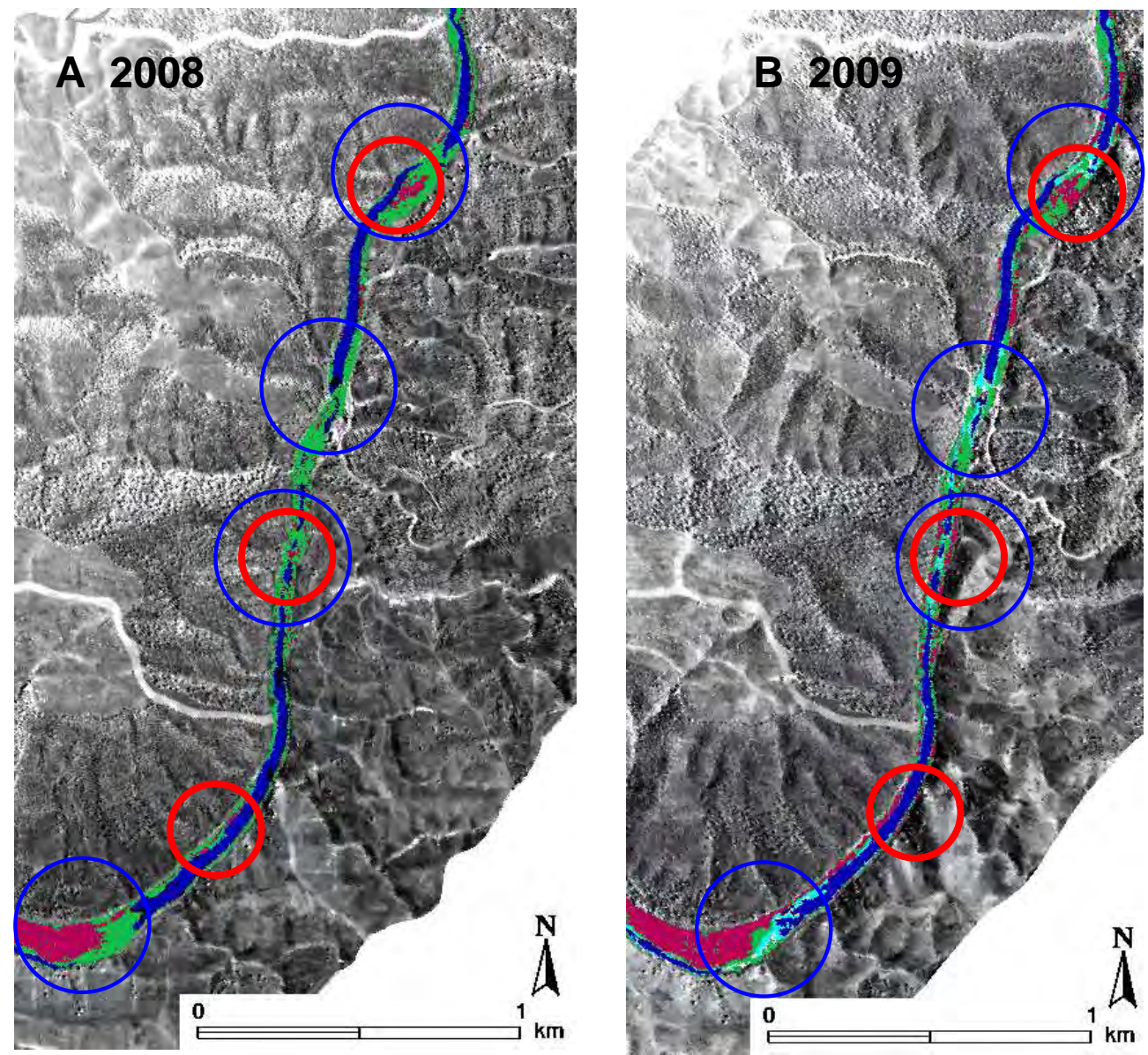

Figure 5.13. The linear encased flow path (Fuente de la Corcha). Maps of coatings over river sediments diagnosed with the reference spectral library (Crowley et al., 2003). Legend as Figure 5.7. A: Map of coatings over river sediments compiled from Hymap data on 4th August 2008. B: Map of coatings over river sediments compiled from Hymap data on $24^{\text {th }}$ August 2009.

Figura 5.13. El curso del río encajado con trazo linear (Fuente de la Corcha). Mapas de costras precipitadas sobre sedimentos fluviales diagnosticados mineralógicamente con la espectroteca de referencia (Crowley et al., 2003). Leyenda según la Figura 5.7. A: Mapa de costras sobre sedimentos fluviales elaborados con imágenes Hymap de 4 de Agosto de 2008. B: Mapa de costras sobre sedimentos fluviales elaborados con imágenes Hymap de 13 de Agosto de 2009. 
$50 \mathrm{~cm}$ diameter) restrict to meanders, where the water looses energy and deposits solid material. Fine grained sediments arrange on high narrow terraces along the borders of the flow path on the linear sections. The terraces of fine grained sand witness the early periods of high floods, when the water is losing energy and depositing the finer grained portion of the solid load transport.

\subsubsection{Changes $2008-2009$}

The water level and the location and size of the river bars are similar in 2008 and 2009, in contrast with previous sections.

Riverbars are covered by schwertmannite and goethite. Goethite grows over the top of the riverbars (Figure 5.13, red circles). In 2008, schwertmannite and goethite are the predominant mineralogies of the coatings of riverbars (Figure 5.13A and Figure 5.13B). In 2009 the overall state of oxidation of riverbars is similar to the previous year. Nevertheless, there are wet areas covered by copiapite surrounding the riverbars and narrow parts of the riverpath with slower water flow (Figures 5.13A and Figure 5.13B, blue circles). Also, there is a comparatively more oxidized diagnosis in 2009 than on 2008 on the terraces along the borders of the river path.

\subsubsection{THE ENTRANCE TO THE ESTUARY (GIBRALEON)}

\subsubsection{Geological and geomorphological setting}

This section of the river is $15 \mathrm{~km}$ in length and is relatively straight. It covers an area from the confluence of the River Odiel with the River Oraque to the entrance to the marshes of the estuary (Figure 5.14A). The already contaminated River Odiel receives contaminated waters from the River Oraque.

Three areas are distinguished by the dominant grain size of river sediments, corresponding to the decreasing transport capacity of the water flow (Riaza et al., 2012a). The riverbars in the northernmost river course are dominated by boulders (Figure 5.14), the middle part is sandy, and the lower course is dominated by mud and fine grained sediments.

The southern area of mud and channels is already an estuarine environment, and the marine water interferes with the precipitation of the iron sulphates from upstream. The chloride of the marine waters neutralises the river acid waters, stopping the 
precipitation of hydrated iron sulphate efflorescence, which are replaced by marine salts.
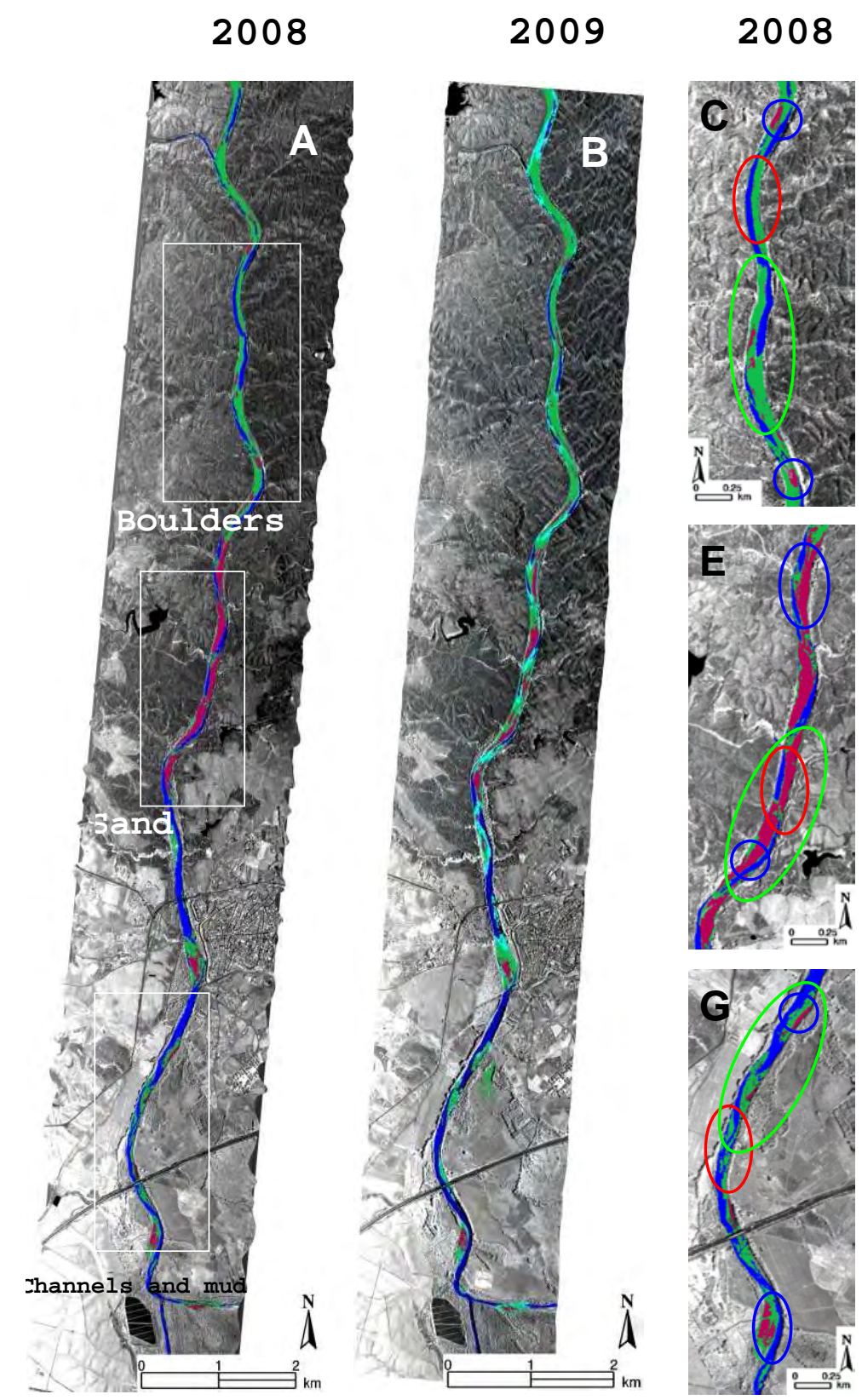

2009
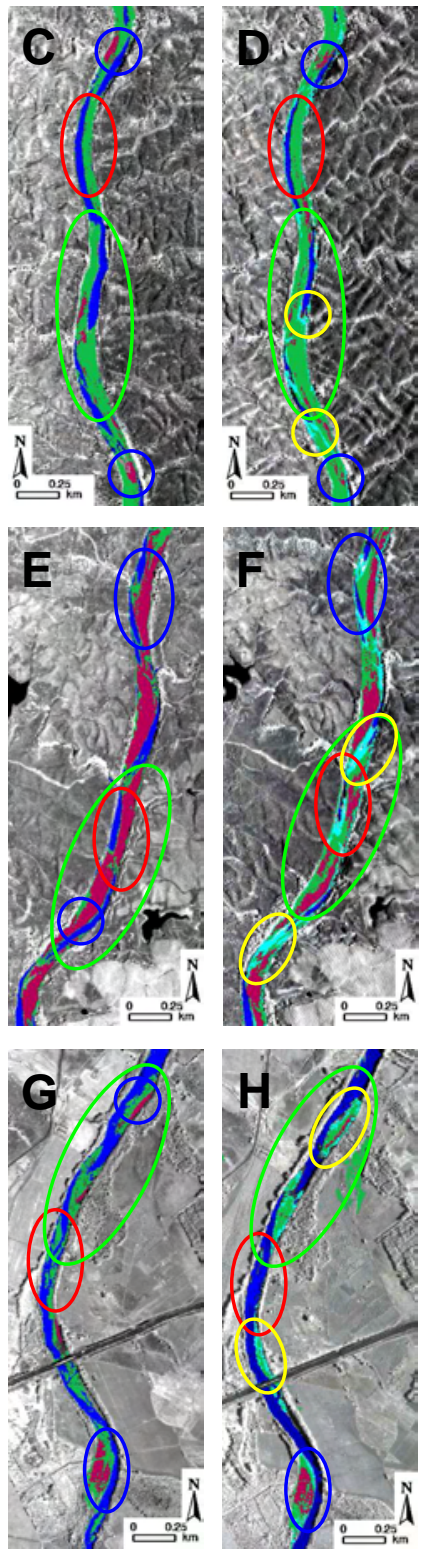

Figure 5.14. The entrance to the estuary. Maps of coatings over river sediments diagnosed with the reference spectral library (Crowley et al., 2003). Legend as Figure 5.7. A: Map of coatings over river sediments compiled from Hymap images in 2008, with sections according to grain size on sediments (Riaza et al., 2012). B: Map of coatings over river sediments compiled from Hymap images in 2009. C: Map of coatings over river sediments of the area of boulders in 2008. D: Map of coatings over river sediments of the area of boulders in 2009. E: Map of coatings over river sediments of the area of sands in 2008. F: Map of coatings over river sediments of the area of sands in 2009. G: Map of coatings over river sediments of the area of channels and mud in 2008. $\mathrm{H}$ : Map of coatings over river sediments of the area of channels and mud in 2009. 
Figura 5.14. La entrada en el estuario. Mapas de costras precipitadas sobre sedimentos fluviales diagnosticados mineralógicamente con la espectroteca de referencia (Crowley et al., 2003). Leyenda según la Figura 5.7. A: Mapa de costras sobre sedimentos fluviales elaborados con imágenes Hymap de 4 de Agosto de 2008, con expresión de subescenas cartografiadas en función del tamaño de grano predominante de los sedimentos (Riaza et al., 2012). B: Mapa de costras sobre sedimentos fluviales elaborados con imágenes Hymap el 13 de Agosto de 2009. C:

Mapa de costras sobre sedimentos fluviales en el área de predominio de cantos elaborados con imágenes Hymap de 4 de Agosto de 2008. D: Mapa de costras sobre sedimentos fluviales en el área de predominio de cantos elaborados con imágenes Hymap de 13 de Agosto de 2009. E: Mapa de costras sobre sedimentos fluviales en el área de predominio de arenas elaborados con imágenes Hymap de 4 de Agosto de 2008. F: Mapa de costras sobre sedimentos fluviales en el área de predominio de arenas elaborados con imágenes Hymap de 13 de Agosto de 2009. G: Mapa de costras sobre sedimentos fluviales en el área de predominio de limos y agua elaborados con

imágenes Hymap de 4 de Agosto de 2008. H: Mapa de costras sobre sedimentos fluviales en el área de predominio de limos y agua elaborados con imágenes Hymap de 13 de Agosto de 2009.

\subsubsection{Changes 2008-2009}

There is an significant drop in the water level from 2008 to 2009 that results in the emersion of wide areas that were flooded in 2008 (Figure 5.14C-Figure 5.14H, red circles). The location and geometry of riverbars is similar from one year to another, and the main changes are restricted to the surface where the water recedes in 2009.

In 2008, in the area of boulders (Figure 5.14C and Figure 5.14D), the river path has well developed and delimited riverbars, with a narrow and sinuous stream. Riverbars are mainly covered by schwertmannite and goethite. Schwertmannite covers most fluvial sediments as uniform coatings (Figure $5.14 \mathrm{C}$, green circle), while goethite is located in the patches topping the riverbars (Figure 5.14C, blue circle). In 2009, schwertmannite remains the main precipitate from sulphide acid mine drainage covering the riverbars (Figure 5.14D, green circle). Goethite recedes from the area covered in 2008 (Figure $5.14 \mathrm{D}$, blue circle). Ribbons with copiapite wrap the river bars (Figure 5.14D, yellow circle).

In the area of sands (Figures 5.14A and 5.14B) (Riaza et al., 2012a), sandbars are displayed as long and homogeneous bodies covered mainly by goethite (Figures $5.14 \mathrm{E}$ and $5.14 \mathrm{~F}$, green circles) both in 2008 as in 2009. Schwertmannite is more abundant in 2009 than in 2008, externally wrapping the riverbars. Instead, goethite reduces its extension in 2009 and remains covering the tops of the riverbars (Figures 5.14E and 
$5.14 \mathrm{~F}$, blue circles). Because of the lowering of the water level, large areas which were flooded in 2008 emerge as muddy surfaces in 2009, and are identified as copiapite (Figure 5.14F, yellow circles). The area of channels and mud (Riaza et al., 2012a) (Figures 5.14A and 5.14B) approaches the estuary, and tides influence the geochemistry of sulphate crusts and the geomorphology of the fluvial sediments (Riaza et al., 2012a). The transport capacity of the river is very low, limited only to fine grained material is suspension deposited as mud. In 2008, riverbars appear isolated on bends of the flow path, and the water channel and mud between bars expands between alternating lingoidal bars using the whole width of the river bed. Mud is abundant, and coarser sediments are restricted to small sandy bars with disrupted patches of boulders that remain on the top of the bars. Mud is uniformly covered by schwertmannite coatings, which is the dominant mineralogy (Figure 5.14G, green circle), while coarser sediments, such as sands and boulders, display oxidised coatings diagnosed as goethite (Figure $5.14 \mathrm{G}$, blue circles). In 2009 the channel is wider than in 2008, the surface used by water contradicts the general higher water level in 2008 than 2009. Tidal influence is responsible for this contradiction. The surface covered by mud is almost absent, and remains only in isolated patches surrounding boulder and sandy bars with coatings of copiapite (Figure 5.14F, yellow circle), which was nearly absent in 2008.

As stated above, the proximity of the sea water has an influence on the chemistry of the precipitate from sulphide acid mine drainages, neutralising the acid waters. Iron sulphate crusts are replaced by marine salts, potassium and magnesium chloride (carnalite), which has a similar spectral response. Therefore, spectral mapping in estuarine areas must be done carefully.

\subsection{SUMMARY OF 2005-2008-2009 CHANGES ON RIVER SEDIMENTS}

The precipitates from acid mine drainage by dissolution of pyrite weathering products covering the fluvial sediments along the River Odiel change over time under the influence of climate and environmental water availability.

The main trend in the mineralogy identified is a generalised oxidation of the precipitated sulphate after dry and warm periods with a low water level, as observed in the summer of 2005. The coarser sediments on top of the riverbars are covered by highly oxidised minerals, such as goethite, while finer sediments are mainly covered by less oxidised minerals, like jarosite. More hydrated minerals, such as schwertmannite, are located next to the water, where there is a regular supply of humidity. 
The most hydrated phases present, such as copiapite, are developed on wet and muddy surfaces that have been recently flooded. After wet periods, as in winter and spring 2008, with intense rainfalls, the area covered by oxidised mineralogical phases covering the river sediments recedes in favour of hydrated sulphate. Thus, in the summer of 2008 there is a lower degree of oxidation in the river sediments, with a wider presence of schwertmannite all along the River Odiel, while goethite and other oxidised minerals remain on top of the riverbars as smaller surfaces than in 2005. The summer of 2009 was preceded by a lowering of the water level. Many areas previously flooded become emerged, and are covered by comparatively more hydrated sulphate, such as schwertmannite and copiapite. Alternating ribbons identified with different mineral phases trace the recent history of flooding in the area.

The neighbourhood of sources of contamination can be traced locally by the mineralogy of the coatings on the river sediments. Their mineralogical changes interact with the water level and climate parameters on differing identifiable paths of mineralogical changes on coatings over river sediments shown by Hymap imagery.

\subsection{DISCUSSION}

Mapping the contamination over the river with hyperspectral airborne data is possible using overlapping flight lines, without major disturbance between spectral variations from adjacent flight lines.

There is a clear spectral response distinguishing areas with contaminated substances from areas free from contamination carried by runoff, both on Hymap imagery and field spectra.

There is a variable reliability on maps produced from Hymap imagery based on the size of areas to map. The maps are more detailed if the outcrop to map is larger. The mineralogical determination is more representative and qualified if the area to map is large enough to allow a detailed statistical pattern. When the areas to map are small, the risk of incorrect mapping is increased.

Progressive subscening isolating masks on areas of potential mineralogical spectral targets is necessary. Nevertheless, the size of many of the mapped geological units consistent with field observations is smaller than the spatial resolution of the imagery. Hymap data is proved to be a formidable mapping tool on contaminating substances on river sediments. 
The atmospheric correction of the imagery is crucial to produce representative maps on substances precipitated from acid mine drainage. Discriminating from more oxidised and intensely hydrated substances is ensured. But minor distinction between mineralogical phases which are closed in the sequence of dehydration on Hymap imagery can be jeopardised by the atmospheric correction.

Both grain size on river sediments and precipitated substances are related to the neighbourhood of water. Both spectral responses become mixed when mapping mineralogical phases precipitated from acid mine drainage over river sediments.

When using spectral libraries as references on a sequence of mapping algorithms, it is important to rely on the endmembers produced from the statistical process previous to the map resulting from the Spectral Angle Mapper. The spectra from regions of interest representing the geological units in the final map are smoothed and are less representative of the spectral features identifying the geological units mapped. This is more critical when the areas to map are small.

Lateral channel movement, erosion and accretion, monitoring by GIS based on spectral features should be implemented. Future data are needed on years with higher and lower water level and variable load transport (planform channel dynamics associated to contaminants).

\subsection{CONCLUSIONS}

The mineralogical changes on the precipitates over the sediments of the River Odiel with hyperspectral Hymap imagery are mapped over three non consecutive years. Such changes respond to climate parameters, water dynamics and distance to the sources of contamination in a complex pattern. Imaging spectroscopy has proved to be an efficient tool to study temporal changes in a rapidly changing geological environment.

Mapping contamination products from sulphide mine waste on a river flow path involves a careful mapping of the river sediments and minor topographical features changing the water dynamics. The minor topography provides the favorable locations to monitor contaminant mineral development.

Changes in the water level of the river under variable climate, and the pattern of river sediments, explain the geochemical evolution of the precipitates from acid mine drainage from dissolved pyrite weathering products. 
A sequence of mapping algorithms is established to produce a final map summarizing the main geological units relevant on the spectral response of contamination on a river course.

The influence on the spectral response of sedimentological parameters on the river sediments, such as grain size, and climate dependent water level or that related to tidal influences on lower reaches of the middle course are discussed on the maps. Both field spectra and Hymap derived spectra have contributed to the interpretation.

The final maps are an accurate geomorphological record of the river sediments and their overlaying coatings of contaminating substances. They faithfully report the geomorphological and geochemical history of the river from the source to the mouth.

The resulting maps, and the geomorphological and climate related relationships drawn, are a solid basis for the routine quantitative and qualitative monitoring of acid mine drainage contamination on the River Odiel using hyperspectral Hymap data. 


\section{CHAPTER 6}

\section{GENERAL CONCLUSIONS}

The work above uses hyperspectral imagery as a mapping tool aiming to monitor the iron sulphide mine waste contamination, both on abandoned mine sites and rivers. Detailed geological mapping of relatively small study areas is based on reference spectral libraries developed in the laboratory of a well known sequence of minerals product of weathering of pyrite. The maps resulting from airborne Hymap or spaceborne Hyperion reveal complex geological and geochemical processes including geomorphology, geochemistry, which can be monitored temporally.

This system is based in the interpretation of time series of hyperspectral data using imaging spectroscopy. This technique is suggested by experts on the environment of mine waste as adequate to monitor inaccessible environments as mine mill tailings, if flights are repeated in a suitable time series.

Raw data recorded by the hyperspectral sensor requires adequate pre-processing operations. The pre-processing chain to convert raw data to reflectance on both sensors is drafted. The resulting imagery with reflectance data can then be interpreted using reference spectral libraries.

The geological interpretation of hyperspectral remote sensing requires specific algorithms, able to manage high dimensional data. The image processing methods to extract geological information, and the sequence of algorithms used to produce maps, both on mine sites and river paths are described.

A routine for mineral mapping through Hymap hyperspectral data analysis is established. Noise and high dimensional data are reduced, through subscening of target areas to be mapped by sequential masking and extraction of representative endmembers. The spectral library of endmembers is mineralogically diagnosed using a reference mineralogical spectral library developed in the laboratory.

Reference spectral libraries are useful to assess the oxidation or hydration stage of a mineral mixture. In addition, they help establish statistical evaluations of scores 
produced by mineralogical diagnoses, which are established by the spectral library using various algorithms. Variations in these scores can be used to improve our understanding of contaminant patterns. Many wrong mineralogical diagnoses can be prevented by considering the geochemical evolution of substances in a known geological context.

Climate is a critical factor that strongly controls the mineralogical evolution of the pyrite weathering products covering river sediments and mine waste. The maps compiled using hyperspectral analysis of Hymap data illustrate the diverse weathering trend of mud tailings and mine waste piles. Mine waste piles on completely abandoned mine sites and riversides affected by acid mine drainage flowing water, may serve to record effects of climate change on a long-term basis. For that purpose, hyperspectral remote sensing data should be acquired at dates chosen at optimal times for observing humidity and temperature.

Mine sites under a recovery process experience mineralogical changes on their surfaces, which are mappable through hyperespectral image processing. The oxidised ashes and the hydrated mud tailings surfaces lose their spectral differences to acquire a uniform spectral response by removal of waste and movement of machinery.

The maps compiled from hyperspectral Hymap data on solid rock mine dumps show that the geomorphology controls the mineralogical trends of the coatings developed on the rock fragments. The dumps are arranged in terraces. The flat tops show spectral oxidised minerals, as hematite and goethite, while the spectra of the surrounding slopes are covered by comparatively more hydrated minerals, mainly schwertmannite. The plains at the foot of the dumps channelling water during rainfall events display coatings of hydrated sulphate as copiapite.

Hymap imagery can be used to effectively display the progressive evolution of mineral growth on geomorphologically identifiable surfaces along the mine dumps and the river path. These confirm changes in temperature, humidity and precipitation recorded by local weather. Most of the areas shown by the imagery as spectrally separable were identified using reference mineral spectral library data. The available ground truth observations and spectral measurements confirm the trends recorded in the multitemporal Hymap data. 
The mapping of contaminating substances on the river using hyperspectral data meets several challenges. Obtaining accurate coordinates of mining-derived contamination along a river channel must initially include the mapping of river sediments and the location of critical contamination points, both of which are strongly influenced by river micro-geomorphology and sedimentology. A major task is to isolate and define the location of water-filled main and side channels where water is located, to avoid misinterpreting landcover features related to contamination. Acidic water in particular can be confused with several hydrated iron sulphates that are typical of pyrite oxidation.

Once the general map in the river is drawn and the general sediment pattern is identified, further image processing on every subscene defined by changes in sediment reveals spectral deviations from the general pattern. Lithology, grain size and river geomorphology are the main parameters controlling river sediments that were mapped. Development of the larger areas of sulphate crusts was concentrated at knick points. These locations can be used as indicators of mineralogical evolution associated with seasonal and climate conditions.

The edge of the water, depositional areas for finer sediments, degree of moisture (wetness), mud, dry or wet vegetative cover, very shallow water with floating vegetation and the spectral influence of the river bottom are the most critical areas relative to the significant display of contamination products and border precipitates, whether from acidic fresh water or marine water. Most hydrated iron sulphate precipitates derived from acidic freshwater can be spectrally confused with potassium and magnesium chloride (carnallite) precipitated from saltwater. When halite (sodium chloride) efflorescence, which is spectrally flat, is present saltwater precipitates are harder to detect. Decreasing acidity may be better detected by the absence of the typical iron sulphate crusts and intense yellow pyrite mud.

Mapping the quality of water is confounded by vegetation, dry or wet, rooted or floating, on the adjacent sediments. The features of acidic water in the field revealed the spectral influence of green vegetation. In the present study it was found that the mixing of saltwater with acidic freshwater resulted in substantial spectral changes related to water chemistry. In particular, acidic water was neutralized by the alkaline, high ionic strength seawater. The influx of the saltwater caused the dropping of the 
overall reflectance and the occurrence of spectral traces of turbid water in the NIR range with longer wavelengths.

Imaging spectroscopy has demonstrated to be a suitable technique to map the $\mathrm{pH}$ of water, whether on mine water bodies or river contaminated water. The spectral response of acidic water has been successfully tested at the point where the Odiel River is supplied with the most intense contamination input, both in the Hymap imagery and the field spectra. The maps produced in this study successfully displayed the parameters of river dynamics related to the estimation of the intensity of contamination or acidity of the water, such as water depth, the presence of vegetation and water transparency. Minor geomorphology in the rivers is crucial to locate the pools of spectrally identifiable acid water behind knick points.

The maps produced from hyperspectral airborne or spaceborne sensors are the main summarizing tool to describe the state of contaminating substances in a highly disturbed region with iron sulphide ore deposits, both in mine sites and river paths. The work performed to date is part of a wider study whose aim is to develop a monitoring system that can provide predictions on water quality estimations, and can be operated by regulators in the future. 


\section{CHAPTER 7}

\section{RESUMEN EXTENSO}

\subsection{OBJETIVO}

Este trabajo está encaminado a desarrollar un sistema de seguimiento de la contaminación producida por los residuos en minas abandonadas de yacimientos de sulfuros de hierro por medio de datos de teledetección hiperespectral. La zona de estudio se encuentra en la Faja Pirítica Ibérica, donde aflora una potente secuencia de pizarras vulcanosedimentarias con abundantes yacimientos de sulfuros.

Se persiguen los siguientes objetivos:

1. Evaluar espectralmente la distribución de minerales en las instalaciones mineras, y en el cauce del río que recibe las sustancias contaminantes. También, establecer una secuencia de algoritmos a partir de imágenes hiperespectrales, que generen mapas en los que se refleje la distribución de las sustancias contaminantes.

La leyenda de los mapas es fiel al diagnóstico que se ha hecho en base a espectrotecas de referencia de la secuencia de los productos de la meteorización de la pirita presenta en las zonas contaminadas. Se han explorado las posibilidades de algoritmos no comerciales como herramientas que contribuyan al seguimiento espectral de la contaminación.

2. Definir una secuencia de algoritmos cartográficos que revelen las tendencias espectrales en las minas abandonadas, que representan ambientes con diferentes evoluciones mineralógicas. Definir esta evolución según una espectroteca de campo elemental y de espectrotecas extraídas de los datos Hymap, esto sirve de base para el seguimiento sistemático de las minas abandonadas.

3. Evaluar la capacidad cartográfica de las imágenes Hymap e Hyperion sobre residuos mineros y cuerpos de agua en minas abandonadas. La influencia de los métodos de corrección atmosférica en la cadena de procesado de imágenes hiperespctrales, la geomorfología de los residuos y la heterogeneidad mineralógica de las áreas 
cartografiadas son los principales parámetros que condicionan el diagnóstico mineralógico de las superficies cartografiadas basado en sus propiedades espectrales.

4. Seguir la evolución mineral en minas abandonadas, tanto por actividades de rehabilitación, o bien sólo bajo la influencia del clima. Los mapas muestran la capacidad de los datos hiperespectrales para detectar cambios tanto en zonas mineras sometidas a un programa de rehabilitación como abandonadas. Los mapas atestiguan fielmente las actividades industriales de limpieza de costras, relleno de balsas y suavizado de pendientes en las escombreras en una mina en rehabilitación. Los mapas también registran fielmente los cambios climáticos cuando no hay actividad industrial, mediante cambios mineralógicos condicionados por la humedad y temperatura ambientales.

5. Seguir la contaminación en el río. El flujo de agua recoge los contaminantes procedentes de los residuos mineros. El río Odiel, cuya cuenca de drenaje está densamente salpicada de minas, se ha cartografiado para buscar los parámetros críticos en el seguimiento de la contaminación. La cartografía de sedimentos fluviales ayuda a identificar las zonas geomorfológicamente favorables para concentrar contaminantes, que pueden cartografiarse con imágenes hiperespectrales. Los rasgos espectrales de los sedimentos fluviales y de las costras de sustancias contaminantes que precipitan sobre ellos interaccionan estrechamente. Así, se detalla el comportamiento espectral de tierra y agua en el ambiente fluvial.

Por lo tanto, se intenta describir las tendencias espectrales de la contaminación en los ambientes de minas y fluvial, y esbozar las líneas generales de un sistema de seguimiento con imágenes hiperespectrales.

\subsection{RESUMEN}

La espectroscopía de imágenes es un instrumento adecuado para el estudio de las escombreras en minas que generan drenaje ácido de minas (AMD, acid mine drainage) (Swayze et al., 2000). Constituye un método indirecto que proporciona información en superficies inaccesibles, como las balsas de lodos (Plumlee, 1999). Tomando datos espectrales, tanto desde el espacio como desde aviones o in situ sobre los residuos mineros, sobre los que se desarrollan costras con distintas asociaciones de minerales, se construyen espectrotecas que permiten hacer estimaciones sobre la composición 
mineralógica de estas costras, y permiten hacer estimaciones de la acidez potencial de las aguas que las disuelven (Crowley et al., 2003).

De este modo, la espectroscopía de imágenes, utilizando datos de sensores embarcados en aviones o satélites, es un método novedoso de seguimiento temporal de la contaminación producida por residuos mineros. Permite realizar estimaciones cartográficas que resumen estadios de evolución de sustancias minerales repetidamente. Reduce el coste económico en personal y equipamiento de las campañas convencionales de recogida de muestras, y análisis químicos y mineralógicos posteriores.

En este trabajo se evalúan parámetros geológicos asociados a la evolución de la contaminación en el entorno de las minas abandonadas, y su manifestación en el río Odiel, que se ponen de manifiesto en las cartografías elaboradas con imágenes hiperespectrales (Capítulos 3, 4 y 5) (Buzzi et al., 2009, 2010a, 2010b). La evolución de los contaminantes está estrechamente ligada al clima y a la geomorfología del entorno que se estudia (Riaza y Müller, 2010). En minas sometidas a rehabilitación, la espectroscopía de imágenes muestra cambios mineralógicos asociados a la recuperación de balsas y escombreras y desmantelamiento de edificios (Buzzi et al., 2010a, 2010b) (Capítulo 3).

Se desarrolla una secuencia de algoritmos de tratamiento de imágenes que guían la elaboración de cartografías con imágenes hiperespectrales (Capítulo 2), y se describen las variables observables en las cartografías digitales en términos de parámetros geoquímicos y vulnerabilidad del medio a la dispersión de contaminantes (Buzzi et al., 2011c; Riaza y Müller, 2010; Riaza et al., 2011a, 2011b, 2012a y 2012b).

De igual manera, se evalúan las limitaciones de los tratamientos previos a la interpretación de imágenes hiperespectrales en los diagnósticos mineralógicos de las unidades cartográficas de los mapas finales (Riaza et al., 2011a), así como de las heterogeneidades espaciales provocadas por los procesos geoquímicos que se desarrollan en los entornos de los residuos mineros y del río Odiel. Estos condicionantes influyen en la fiabilidad de las espectrotecas de referencia como elementos de diagnóstico mineralógico, tanto en espectros de campo como en imágenes hiperespectrales aeroportadas o de satélite. 


\subsection{INTRODUCCION}

Este trabajo se enmarca en la extracción de información geológica de imágenes hiperespectrales embarcadas en aviones (Hymap) o satélites (Hyperion), utilizando espectrotecas de referencia elaboradas en laboratorio (Crowley et al., 2003). Se aplica al seguimiento de la contaminación producida por residuos mineros de yacimientos de sulfuros masivos en la Faja Pirítica Ibérica. Así, se elaboran digitalmente cartografías que reflejan la distribución espacial y evolución temporal de productos de la meteorización piritas en residuos mineros (Capítulos 3 y 4) (Buzzi et al., 2010a, 2010b, 2011a, 2011b, 2011c, 2012; Riaza y Müller, 2010; Riaza et al., 2011a, 2011b, 2012b). También se cartografían los sulfatos que precipitan a partir de aguas ácidas sobre los sedimentos fluviales a lo largo del curso del río Odiel (Capítulo 5) (Buzzi et al., 2011a, 2011b, 2011c, 2012; Riaza y Carrère, 2010; Riaza et al., 2012a), y su interacción con la disposición de los sedimentos y la hidrodinámica del río, en función de sus propiedades espectrales.

La zona de estudio se encuentra en el suroeste de la Península Ibérica (Figura 1.1.) y se centra en dos minas abandonadas, Sotiel y Las Herrerías, y el curso del río Odiel. La mina de Sotiel, situada en las orillas del curso medio del río Odiel (Figura 1.2), es una mina en rehabilitación desde 2006. La mina de Las Herrerías (comarca de Andévalo), abandonada en los años ochenta, ha evolucionado desde entonces en superficie bajo la sola influencia de la atmósfera. Para seguir los cambios de las sustancias contaminantes en estos ambientes se estudian vuelos Hymap en los veranos de 2005, 2008 y 2009, e imágenes Hyperion en los veranos de 2006 y 2007.

La zona de estudio se sitúa geológicamente en la Faja Pirítica Ibérica, perteneciente a la Zona Surportuguesa del Macizo Hespérico (Figura 1.1). La mayor parte de los afloramientos pertenecen al Complejo Vulcano-Sedimentario (CVS), una serie sedimentaria de edad Carbonífero inferior, de rocas formadas con aportes detríticos volcánicos, que han sufrido metamorfismo regional de muy bajo grado. El CVS alberga yacimientos de sulfuros masivos formados sinsedimentariamente por procesos hidrotermales ligados al vulcanismo del Carbonífero inferior. Los sulfuros presentes en los yacimientos son principalmente pirita $\left(\mathrm{FeS}_{2}\right)$, además de galena $(\mathrm{PbS})$, esfalerita $((\mathrm{Zn}, \mathrm{Fe}) \mathrm{S})$, casiterita $\left(\mathrm{SnO}_{2}\right)$ y calcopirita $\left(\mathrm{CuFeS}_{2}\right)$ (Vera et al., 2004).

Los yacimientos de sulfuros complejos se han explotado en la Faja Pirítica Ibérica a lo largo de los últimos 5000 años (Leblanc et al., 2000). Los residuos generados por la 
explotación minera, acumulados en escombreras y aún ricos en pirita, se meteorizan por la acción de los agentes atmosféricos, generando ácido sulfúrico disuelto en el agua y precipitados de hidróxidos de hierro, según la siguiente reacción simplificada (Nordstrom y Alpers, 1999):

$\mathrm{FeS}_{2(\mathrm{aq})}+15 / 4 \mathrm{O}_{2(\mathrm{~g})}+7 / 2 \mathrm{H}_{2} \mathrm{O}_{(\mathrm{l})} \rightarrow \mathrm{Fe}(\mathrm{OH})_{3(\mathrm{~s})}+2 \mathrm{H}_{2} \mathrm{SO}_{4(\mathrm{aq})}$

Los procesos de meteorización de piritas también provocan la aparición de sulfatos de hierro hidratados, muy inestables, que precipitan y se disuelven fácilmente en el agua en rangos muy definidos de $\mathrm{pH}$, y que contribuyen al aumento de la acidez de las aguas de la red fluvial, y a la movilización de metales pesados. Parte de estas sustancias son arrastradas por la red fluvial, y precipitan posteriormente sobre los sedimentos del río en forma de costras y eflorescencias de sulfatos hidratados de hierro altamente solubles, tales como copiapita y schwertmanita. La evolución geoquímica de estos precipitados está condicionada por el clima, y refleja las condiciones de humedad y temperatura ambientales. El estudio de series temporales de estos datos con cartografías elaboradas a partir de imágenes hiperespectrales contribuye a predecir la calidad del agua de escorrentía con periodicidad establecida por los vuelos programados, y a asesorar las posibles medidas a tomar por los reguladores (Riaza y Müller, 2010).

El clima de la zona de estudio es semiárido, caracterizado por la presencia de una época muy lluviosa a principio del otoño y una época relativamente seca durante el resto del año. Se ha comprobado que el clima es un factor decisivo en la evolución geoquímica de los productos de la meteorización de la pirita (Riaza y Müller, 2010). Las lluvias intensas del otoño provocan inundaciones, que disuelven las costras precipitadas a lo largo del cauce. A medida que desciende de nuevo el caudal a lo largo del año siguiente, precipitan de nuevo sulfatos de hierro altamente hidratados, que van evolucionando hacia fases más oxidadas y deshidratadas a medida que disminuye el aporte de humedad y aumentan las temperaturas a lo largo del año. El máximo grado de oxidación se da en verano. Las intensas lluvias del siguiente otoño disuelven los minerales más solubles, mientras que los más oxidados y estables permanecen. El ciclo se repite acompañando al año hidrológico.

Las cartografías elaboradas en minas abandonadas con imágenes Hymap demuestran la estrecha relación que existe entre el clima y el grado de oxidación de los minerales precipitados sobre los sedimentos del río y presentes en las escombreras de las minas 
(Buzzi et al., 2010a, 2010b, 2011a, 2011b, 2011c, 2012; Riaza y Müller, 2010; Riaza y Carrère, 2010; Riaza et al., 2011a, 2011b, 2012a y 2012b). En los años con precipitación escasa y temperaturas elevadas, tanto en el los sedimentos del río Odiel como en el ámbito de las minas abandonadas, las costras de minerales producto de la meteorización de la pirita aparecen fuertemente oxidadas en entornos geomorfológicamente favorables, mientras que en los años de climatología más húmeda y fresca, las costras de sulfatos hidratados alcanzan mayor extensión espacial (Capítulos 3, 4 y 5). También, las variaciones relativas del caudal del río Odiel están ligadas al grado de oxidación de las sustancias precipitadas sobre los sedimentos del mismo (Capitulo 5).

Desde 2005, en que este estudio recibe financiación del Plan Nacional de Investigación, se han desarrollado cartografías de sustancias asociadas a la oxidación de piritas en minas abandonadas y cauces fluviales cercanos (Buzzi et al., 2010a, 2010b, 2011a, 2011b, 2011c, 2012; Riaza et al., 2006, 2007, 2011a, 2011b, 2012a, 2012b; Riaza y Müller, 2010; Riaza y Carrère, 2010).

\subsection{ESPECTROSCOPÍA DE IMÁGENES APLICADA AL SEGUIMIENTO DE LA CONTAMINACION PRODUCIDA POR RESIDUOS MINEROS}

La espectroscopía de imágenes se utiliza en este estudio para la extracción de información geológica relacionada con la contaminación producida por los residuos mineros de yacimientos de sulfuros complejos. Se basa en el comportamiento espectral de las superficies que ocupan las minas abandonadas, o las sustancias contaminantes que generan y se diseminan en el entorno. Para ello se vale del tratamiento digital de imágenes (Capítulo 2).

El proceso de oxidación de sulfuro de hierro sigue una secuencia mineralógica bien conocida (Buurman, 1975). Se ha desarrollado una espectroteca de referencia en laboratorio sobre todas las sustancias minerales implicadas en el proceso (Crowley et al., 2003). La espectroscopía de imágenes aeroportadas o de satélite permite estudiar entornos inaccesibles en los residuos mineros. Ofrece un diagnóstico mineralógico rápido y menos costoso que los métodos tradicionales de recolección de muestras, y consiguiente análisis mineralógico y químico. Y, por último, permite expresar cartográficamente las áreas cubiertas por distintos minerales. De esta manera, las superficies cartografiadas se relacionan con parámetros asociados a procesos complejos, condicionados por la geomorfología, que enriquecen la interpretación 
ambiental de los datos obtenidos. La espectroscopía de imágenes como instrumento cartográfico es una herramienta insustituible en los estudios ambientales de contaminación por residuos mineros.

Se han realizado mapas con series históricas de imágenes Hymap en la zona de estudio (Riaza et al., 2007; Riaza y Müller, 2010; Buzzi et al., 2010a, 2010b, 2012), que sugieren que la distribución de costras de minerales de meteorización de pirita sobre los residuos mineros y los sedimentos fluviales, depende de las fluctuaciones en humedad y evaporación. Estos mapas pueden utilizarse como un registro de variabilidad climática, con periodicidad dependiente de los datos disponibles (Capítulos 4 y 5). Para ilustrar estas observaciones, se realizaron estudios espectrales de campo y laboratorio, que siguieron cambios espectrales sobre residuos mineros durante la estación seca. Los cambios experimentados por los espectros constataron cambios mineralógicos sutiles detectables con valoraciones estadísticas utilizando varios algoritmos de análisis espectral (Riaza et al., 2011b).

Según estas experiencias, se sugieren cambios revelados por el diagnóstico mineralógico de productos de meteorización de piritas, por medio de espectrotecas desarrolladas en un contexto geológico preciso (Clark et al., 2007; Crowley et al., 2003), tanto sobre en escombreras como en balsas de lodos y sedimentos fluviales (Buzzi et al., 2009, 2010a, 2010b, 2011a, 2011b, 2011c, 2012; Riaza et al., 2006, 2011a, 2012a, 2012b). También se evaluó la influencia de la geomorfología en la respuesta espectral de las superficies sobre las que se desarrollan costras de minerales que se cartografían en las imágenes hiperespectrales (Riaza et al., 2010). Los mapas que se elaboran a partir de estas imágenes son el instrumento de interpretación y resumen de observaciones, tanto espectrales como geológicas (Capítulos 3 y 4).

La cartografía de los productos de meteorización de piritas que aparecen sobre los sedimentos fluviales ha exigido elaborar una cartografía previa de estos sedimentos y de la geomorfología (Riaza et al., 2012a; Buzzi et al., 2012), en dos años sucesivos. La microgeomorfología del curso del río controla los entornos favorables para el seguimiento de las sustancias contaminantes (Capítulo 5). Los espectros de las superficies cartografiadas con imágenes Hymap en los sedimentos del río, se han diagnosticado mineralógicamente utilizando la espectroteca de referencia de los minerales producto de oxidación de piritas (Crowley et al., 2003). El diagnóstico mineralógico emplea algoritmos estandarizados y automatizados (Capítulo 2), por lo 
que durante todo el proceso de cartografía se requiere de una evaluación cuidadosa del contexto geológico, con el fin de proporcionar una información ambiental representativa de los parámetros geomorfológicos, mineralógicos y geoquímicos que se asocian a la contaminación en las cartografías elaboradas.

\subsection{DATOS}

\subsubsection{IMÁGENES}

El sensor aeroportado Hymap y el sensor embarcado en satélite Hyperion captan las imágenes analizadas en este trabajo (Capítulo 2). Hymap es un sensor hiperespectral que toma los datos desde un avión. Ofrece imágenes de alta resolución espacial y espectral, gracias a las cuales se puede identificar con detalle la distribución y composición de los minerales que aparecen en la zona estudiada. Las imágenes Hymap tienen una resolución espacial de $4 \mathrm{~m}$ para una altura de vuelo de $2000 \mathrm{~m}$. Cada imagen está compuesta por 126 bandas espectrales distribuidas entre los $450 \mathrm{~nm}$ y los $2480 \mathrm{~nm}$ con una resolución espectral de 13-17 nm.

Hyperion es un sensor hiperespectral que toma los datos desde el satélite EO-1, situado en una órbita polar a $705 \mathrm{~km}$ de altura. Su periodo orbital es de 98.7 minutos y su resolución temporal es de 17 días. Tiene 220 bandas distribuidas entre los $400 \mathrm{~nm}$ y los $2400 \mathrm{~nm}$ cada $10 \mathrm{~nm}$. Si bien su resolución espacial de $30 \mathrm{~m}$, es menor que la de Hymap, su mayor campo de visión permite realizar una cartografía de áreas más extensas.

\subsubsection{ESPECTROMETRÍA DE CAMPO}

Se ha realizado un minucioso trabajo de campo, tomando medidas espectrales en los puntos más representativos mediante un espectrómetro de campo ASD FieldSpec 3 (350-2500 nm, resolución espectral de $1 \mathrm{~nm}$ ). En conjunto, casi mil espectros geológicamente documentados se han medido entre escombreras y sedimentos fluviales, tomados en campo o en laboratorio (Capítulo 2).

\subsubsection{ESPECTROTECA DE REFERENCIA}

La interpretación mineralógica de los mapas elaborados con imágenes hiperespectrales se realiza con una espectroteca de referencia elaborada en laboratorio de los minerales producto de meteorización de piritas (Crowley et al., 2003), basada en la secuencia de evolución mineralógica (Buurman, 1975). La espectroteca de referencia contiene datos 
de reflectancia en los mismos intervalos de longitudes de onda que los sensores Hymap y Hyperion (350 nm-2500 nm).

\subsubsection{GEOQUIMICA Y OTROS}

En muestras representativas, se efectuaron análisis mineralógicos, químicos y de difracción de rayos X. En muestras de agua se hicieron análisis físico-químicos (Capítulo 2).

También se usaron datos climáticos proporcionados por la Agencia Estatal de Meteorología para la interpretación de las cartografías de unidades geológicas y costras minerales en función de las condiciones ambientales previas.

\subsection{CARTOGRAFÍA CON TRATAMIENTO DIGITAL DE IMÁGENES}

Cada imagen hiperespectral está formada por decenas de capas de datos bidimensionales, que requieren algoritmos de tratamiento digital capaces de explorar datos con una alta dimensionalidad. En este trabajo se describe la cadena de tratamientos aplicados a los datos brutos antes de la fase de interpretación (RSI, 2000), así como la secuencia de algoritmos aplicados para la extracción de información geológica y la producción de mapas (Capítulo 2).

Los datos procedentes de sensores hiperespectrales requieren una serie de tratamientos previos que transforman la información recogida por el sensor en datos de radiancia (Capítulos 2.3 y 2.4). Posteriormente se aplican una serie de algoritmos destinados a corregir los efectos que tienen la atmósfera y la topografía sobre la radiancia del terreno. Finalmente los datos de radiancia se transforman en datos de reflectancia, lo que permite la interpretación de los espectros mediante espectrotecas de referencia, elaboradas ya sea en laboratorio o en el campo.

Para extraer información geológica según la respuesta espectral, se ha diseñado una rutina de procesado de imágenes Hymap basada en el aislamiento de las zonas objeto de estudio mediante máscaras y la aplicación sucesiva de algoritmos estándar, destinados a reducir la dimensionalidad de los datos (Capítulo 2.7 y 2.8) con criterios geológicos (Figura 2.1, Figura 2.2). De esta manera, se identifican los miembros extremos (endmembers), que se usan como entrada de los algoritmos cartográficos que producen mapas de unidades geológicas espectralmente homogéneas. Tras un diagnóstico mineralógico con la espectroteca de referencia (Crowley et al., 2003), se 
crea un mapa de superficies cubiertas por costras de minerales producto de oxidación de piritas (Figura 2.3, Figura 2.4, Figura 2.5).

\subsection{CARTOGRAFIA DE PRODUCTOS DE OXIDACION DE PIRITAS EN UNA MINA EN PROCESO DE REHABILITACION (SOTIEL, HUELVA) CON IMÁGENES HIPERESPECTRALES AEROPORTADAS HYMAP}

En las minas de Sotiel se han explotado sulfuros complejos desde tiempos históricos hasta 1991. Las instalaciones más recientes constan de una planta de tratamiento de menas, una balsa de almacenamiento de cenizas y otra de lodos, así como unas escombreras situadas junto al cauce del río Odiel. En 2006 comenzaron las tareas de restauración, consistentes en el vaciado y sellado de la balsa de cenizas (finalizado en 2006), y la limpieza de los alrededores de la planta de tratamiento. El drenaje y vaciado de la balsa de lodos comenzó en 2008, continuó en 2009, y aún estaba en proceso en el verano de 2011.

Se ha realizado el seguimiento de la evolución espectral del área de las antiguas explotaciones mineras mediante el análisis de imágenes del sensor Hymap de tres vuelos: 2005, 2008 y 2009, utilizando una espectroteca de referencia para los productos de la meteorización de la pirita (Crowley et al., 2003) (Capitulo 3). Comparando las cartografías obtenidas (Figura 3.3, Figura 3.5, Figura 3.9, Figura 3.11), se ha establecido una relación entre los minerales de las costras, las condiciones climáticas dominantes a lo largo del periodo precedente al vuelo, y la geomorfología del entorno ambiental (Buzzi et al., 2009, 2010a, 2010b).

\subsubsection{BALSA DE CENIZAS}

Según las cartografías elaboradas con Hymap, en 2005 las costras de minerales asociados a la meteorización de sulfuros de hierro que cubren el norte de la balsa de cenizas presentan composiciones fuertemente oxidadas. Las líneas de drenaje de agua de cualquier dimensión, como surcos y canales, se distinguen en las imágenes Hymap por la presencia de costras de sulfatos más hidratados (Figura 3.2). En 2008 y 2009 la balsa de cenizas ya estaba rehabilitada. En Agosto de 2008 aparecía cubierta por hierba seca, y la respuesta espectral que presenta es la típica de la vegetación senescente. En cambio, en 2009 habían segado la vegetación seca para prevenir incendios, y las imágenes Hymap ofrecen la respuesta espectral del suelo que se desarrolla sobre las rocas del Complejo Vulcano-Sedimentario circundante (Figura 3.4). 


\subsubsection{ESCOMBRERAS}

Las escombreras, que acumulan trozos de roca, situadas en las proximidades del río Odiel, configuran un paisaje de terrazas, cuyas características geomorfológicas enmarcan la distribución y evolución de las costras de sustancias minerales producto de la meteorización de sulfuro de hierro que las cubren (Figura 3.5). Las escombreras a orillas del río han permanecido estables hasta 2009, último vuelo Hymap estudiado. Según las cartografías elaboradas con imágenes Hymap, las cimas planas y estables de las terrazas, tienden a presentar asociaciones minerales oxidadas, mientras que en los taludes la mineralogía de las costras de sulfatos de hierro es más hidratada debido a los procesos de escorrentía y la inestabilidad de materiales. En las depresiones al pie de las escombreras aterrazadas, por las que se drena el agua en épocas de lluvias, se depositan materiales de grano fino que presentan preferencia por cubrirse de costras de sulfatos hidratados.

Según las cartografías elaboradas con imágenes Hymap, en 2005 las superficies planas en lo alto de las terrazas presentan un alto grado de oxidación (Figura 3.5A, círculos amarillos), mientras que los taludes están cubiertos por sulfatos de hierro comparativamente más hidratados (schwertmanita). Las zonas deprimidas aparecen cubiertas por sulfatos de hierro muy hidratados (copiapita).

En 2008, las superficies altas de las terrazas aún están cubiertas por hematites (Figura 3.5B, círculos amarillos), pero los taludes se han oxidado a goethita (Figura $3.5 \mathrm{~B}$, círculos azules). La schwertmanita aparece en parches en los taludes de las escombreras externas (Figura 3.5B, círculos magenta), alternando con franjas estrechas de copiapita. Las superficies cubiertas por copiapita mantienen su posición, pero reduciendo ligeramente su extensión (Figura 3.5A y Figura 3.5B, círculos rojos).

La distribución de minerales observada en 2009 muestra un incremento en la oxidación de las superficies planas y los taludes de las escombreras respecto a 2008. También, se observa un incremento en la extensión de la hidratación en las áreas topográficamente más bajas y en las pendientes suaves del arroyo occidental. Sin embargo, el invierno y la primavera de 2008 son secos en comparación con las precipitaciones y temperaturas normales del invierno y la primavera de 2009. Los cambios en las costras minerales sobre las depresiones al pie de las escombreras y los efímeros arroyos estivales, reflejan fielmente las condiciones de precipitación y temperatura de las estaciones del año anteriores. Algunas áreas menores en los taludes 
septentrionales de la escombrera mayor muestran la misma tendencia, pero las extensas superficies planas superiores de las escombreras, cubiertas de hematites, no reflejan los mismos cambios climáticos en 2008 y 2009.

\subsubsection{BALSA DE LODOS}

Según las cartografías elaboradas con imágenes Hymap, en 2005 la balsa de lodos aparece cubierta principalmente por minerales hidratados (Figura 3.9). La distribución de minerales en la superficie de la masa de lodos evidencia las zonas de aporte, como el abanico cubierto de costras de pickeringita al pie del canal de drenaje desde la balsa de cenizas. Las zonas que están más oxidadas, cubiertas con costras de goethita y jarosita, jalonan el borde de la charca detrás de la pared de la pared de la presa. La microgeomorfología de la superficie de esta masa densa de lodos, que se mueve internamente, muestra una superficie en la que se dibujan drenajes de agua y crestas suaves. La superficie externa está cubierta mayoritariamente por szomolnokita, según las imágenes Hymap, mientras que la rozenita, un sulfato de hierro más hidratado que la szomolnokita, cubre el fondo de los microcanales.

La balsa de lodos se deshidrata progresivamente desde el verano de 2005 a 2009, el último vuelo Hymap disponible, y no recibe residuos desde el año 2006 en que se rehabilitó la balsa septentrional de cenizas. En 2008 el grado de oxidación es mayor que en 2005, y la extensión de los minerales hidratados se reduce.

La balsa de lodos empezó a rehabilitarse en 2009. Los lodos se retiraron, se drenó el agua, y en verano la superficie del fondo estaba en reposo para consolidarse, antes de permitir la entrada de maquinaria. Las costras de sulfatos hidratados como halotriquita se reducen a una pequeña extensión alrededor del charco de agua junto a la pared de la presa, mientras que el resto de la balsa está cubierta por minerales comparativamente más oxidados (Figura 3.9C).

\subsubsection{PLANTA DE TRATAMIENTO DE MENAS}

En 2005 los alrededores de la planta de tratamiento de menas aparecen cubiertos principalmente por minerales hidratados (Figura 3.11A), como paracoquimbita y pickeringita. Hay puntos con mayor grado de oxidación en zonas externas, con jarosita y goethita, alejadas de la influencia de los aportes de residuos altamente hidratados generados en los talleres de la planta. 
En 2008 se habían limpiado los alrededores de la planta de tratamiento de costras, y los taludes de las escombreras se habían suavizado. La superficie de esta zona muestra un grado de oxidación mucho mayor que en 2005 (Figura 3.11B), con goethita y ferrihidrita.

En 2009 se estaban realizando tareas de desmantelamiento de la planta de tratamiento de menas, con movimiento de maquinaria intenso. Los sulfatos de hierro moderadamente hidratados predominan en sus alrededores, de manera homogénea con el resto la explotación, balsa de lodos incluida (Figura 3.11C).

\subsection{CARTOGRAFIA DE RESIDUOS MINEROS Y CUERPOS DE AGUA EN UNA MINA DE SULFUROS DE HIERRO CON IMÁGENES AEROPORTADAS HYMAP Y IMÁGENES HYPERION DE SATÉLITE (MINA DE LAS HERRERÍAS, HUELVA)}

La mina de Las Herrerías dejó de operar a finales de los años ochenta, y los residuos almacenados en ella han evolucionado desde entonces bajo la sola influencia de los agentes atmosféricos (capítulo 4).

Los mapas elaborados con imágenes Hymap y Hyperion en la mina de Las Herrerías (Huelva) muestran las mismas tendencias en las unidades que agrupan mezclas de minerales (Riaza et al., 2012b), controladas por la geomorfología de las escombreras de fragmentos de roca (Figura 4.1 y Figura 4.4). Las imágenes Hymap, con mayor resolución espacial y mejor relación señal/ruido, guiaron la elaboración digital de cartografías con imágenes Hyperion. A pesar de ello, las imágenes Hyperion son capaces de discriminar, no sólo las unidades más extensas de mezclas de minerales en las escombreras cartografiadas con imágenes Hymap, sino también áreas pequeñas cubiertas con costras de sulfatos hidratados en antiguas balsas desecadas. Las imágenes Hyperion del año 2007 sugieren una zona amplia con sulfatos hidratados que no aparece en las cartografías de 2005 ni de 2006 (Figura 4.5).

Las zonas en las que aparecen sulfatos hidratados son críticas como indicadores que cambios mineralógicos relacionados con la variabilidad climática. Los espectros de campo en áreas que en su día se utilizaron como balsas de lixiviado, hoy desecadas, muestran formas que corresponden típicamente a sulfatos hidratados. El espectrómetro de campo mide costras finísimas, que recubren arenas o limos en estas balsas desecadas, con espesores a veces inferiores al milímetro. Los minerales de estas costras precipitan sobre las arenas, se disuelven cuando llueve, y reprecipitan cuando 
se evapora el agua sobre la superficie. No se conoce la rapidez con la que se dan estos fenómenos de disolución y reprecipitación, ni el rango de cambios térmicos y de humedad necesarios para que se produzcan cambios mineralógicos significativos.

La respuesta espectral de los cuerpos de agua es muy variable, tanto en las balsas de la mina abandonada como en los embalses que proveen agua potable y almacenan agua residual de la población vecina (Figura 4.9 y Figura 4.10). Los espectros en las imágenes Hymap y Hyperion son sensibles a los cambios en la geoquímica del agua, y los mapas realizados se relacionan directamente con parámetros de calidad de agua, tales como el pH. Sin embargo, hay discrepancias en las respuestas espectrales típicas del aumento de acidez en el agua observadas en cursos fluviales (Riaza et al., 2012a), representadas por los espectros de las balsas en las dos cortas, llamadas localmente "balsa de piritas" ( $\mathrm{pH}$ 3) y de "balsa de cobre" (pH 6). Los espectros procedentes de las imágenes Hymap y los espectros medidos en campo coinciden en la respuesta espectral en ambas balsas. La profundidad del agua, la influencia del viento, o la misma geoquímica del agua que se asocia a otras propiedades físicas, como la fluorescencia, pueden explicar estas discrepancias en la respuesta espectral.

\subsection{CARTOGRAFIA DE UN RÍO CONTAMINADO CON DATOS AEROPORTADOS HYMAP (RIO ODIEL, HUELVA)}

El río Odiel nace en la Sierra de Aracena y fluye de norte a sur hacia el océano Atlántico en un canal de baja sinuosidad que tiende a cortar perpendicularmente la estratigrafía. El caudal del río está controlado principalmente por el régimen de precipitaciones, con la excepción de la entrada al estuario, bajo la influencia de las mareas.

El transporte de sedimentos se realiza principalmente por arrastre de fondo. A lo largo de su curso se desarrollan barras fluviales centrales y laterales, controladas por la energía de transporte en cada tramo, mayor en la cabecera y menor en los tramos más bajos. El desarrollo de cuerpos sedimentarios fluviales también está condicionado por la energía de transporte.

El río Odiel recibe aguas contaminadas procedentes de las numerosas explotaciones mineras que hay a lo largo de su curso (Figura 1.2), con altas concentraciones de sulfatos y metales pesados procedentes de los procesos de drenaje ácido (Apartados 5.1.1 y 5.1.2). Cuando el nivel del río disminuye durante el estiaje, los sulfatos disueltos en el agua precipitan sobre los sedimentos en forma de costras y eflorescencias, y van 
oxidándose progresivamente. El grado de oxidación de estos minerales está controlado por las condiciones climáticas que se dan durante su evolución, por la proximidad de las fuentes de contaminación y por la geomorfología del cuerpo sedimentario sobre el que se encuentran.

La espectroscopía de imágenes, aplicada a los datos tomados por el sensor Hymap en los años 2005, 2008 y 2009 ha servido para evaluar la distribución y evolución de las sustancias contaminantes procedentes de los productos de la meteorización de la pirita a lo largo del cauce del río (Buzzi et al., 2011a, 2011b, 2011c, 2012). También se tomaron mediciones de espectrometría in situ y muestras de agua y de sedimentos para su análisis químico.

En las imágenes Hymap, la respuesta espectral de los sedimentos está directamente relacionada con el tamaño de grano de los mismos; así, los sedimentos más gruesos (cantos, gravas) tienen mayor reflectancia en todo el rango de longitudes de onda, mientras que los más finos (arenas, limos) tienen una reflectancia alta en el visible y más baja en el infrarrojo (Figura 5.2).

El diagnóstico mineralógico de los productos de la meteorización de la pirita que cubren los sedimentos del río Odiel se ha realizado tomando como referencia una espectroteca elaborada en laboratorio específicamente para el estudio de zonas afectadas por la contaminación producida por la minería de sulfuros masivos (Crowley et al., 2003).

Otras características de los sedimentos, tales como la oxidación de granos de cuarzo, la presencia de micas o la presencia de materia orgánica en los sedimentos finos, puede identificarse a través de rasgos característicos que muestran en sus espectros (Capítulo $5 \cdot 3)$.

\subsubsection{LA CABECERA DEL RIO (CAMPOFRÍO)}

Según las imágenes Hymap, en la cabecera del río, enclavada en la Sierra de Aracena, los sedimentos fluviales tienen escaso desarrollo y las aguas del río suelen aparecer cubiertas por la vegetación que crece en las orillas. En los sedimentos no se ha detectado la firma espectral de ningún mineral procedente de la meteorización de la pirita ni en las imágenes Hymap ni en los espectros medidos en campo, lo que es coherente con el hecho de que no exista ninguna explotación minera que vierta contaminación aguas arriba. 
Las principales diferencias entre los años 2008 y 2009 se dan en la distribución de los sedimentos fluviales (Figura 5.5). En 2008, las intensas precipitaciones de la primavera aumentaron el caudal y la capacidad de transporte del río. Las cartografías elaboradas con imágenes Hymap muestran que las arenas depositadas sobre la llanura de inundación adquieren mayor desarrollo en el verano de 2008 que en 2009.

\subsubsection{EL PRIMER APORTE DE CONTAMINACION INTENSA (PUENTE DE LOS CINCO OJOS)}

El primer aporte importante de contaminación que recibe el río Odiel procede de las explotaciones mineras de Río Tinto. Las balsas de gossan vierten aguas contaminadas cargadas en hierro y metales pesados por medio de un afluente al río Odiel. A partir de la confluencia, hay un mayor desarrollo de las barras fluviales, y el pH de las aguas se acidifica, pasando de 6 a 3-4.

\subsubsection{Cartografía de sedimentos y costras}

Al comparar las imágenes Hymap de 2008 y 2009 (Figura 5.7), se observa que las barras fluviales aparecen en las mismas posiciones en ambos años, sugiriendo que la capacidad de transporte del río fue similar entre los periodos húmedos respectivos. El nivel del agua disminuyó en 2009 respecto a 2008, exponiendo a la atmósfera grandes áreas cubiertas por sedimentos finos que sufrieron una deshidratación progresiva.

Debido a la presencia de mayores áreas cartografiables en 2009, el mapa de este año es más detallado que el de 2008. La variedad de unidades identificadas se reduce al aplicar el módulo de ENVI de Análisis Espectral (Spectral Analyst: RSI, 2000), que obliga a fusionar las primeras unidades identificadas en otras más amplias (Riaza et al., 2011b).

En las barras fluviales identificadas en 2008, tan sólo los cantos de las partes altas aparecen cubiertos por minerales oxidados (goethita), mientras que el resto de la barra y los bordes están cubiertos por schwertmanita (Figura 5.7A, círculos rojos). En 2009 las barras están comparativamente más oxidadas. Los bordes de schwertmanita alrededor de las franjas de arenas finas se reducen en 2009.

El mapa de las barras de 2009 muestra más detalles acerca del estado de oxidación de los cantos y las arenas. Las áreas inundadas en 2008 que se exponen a la atmósfera en 2009, se identifican por una secuencia de minerales progresivamente menos oxidados 
hacia el agua (Figura 5.7B, círculo rojo). El tamaño de grano de los sedimentos fluviales también disminuye hacia el agua. Ambos parámetros evolucionan juntos y no pueden individualizarse en el mapa.

En el mapa de 2009 también se observan franjas de costras de sulfatos hidratados a lo largo de bordes rectilíneos del agua (Figura 5.7B, círculo amarillo). En 2009, en la confluencia del río Odiel con el tributario altamente contaminado, aparecen extensas áreas cubiertas por costras de sulfatos hidratados (Figura $5 \cdot 7 \mathrm{~B}$, círculo añil), donde la schwertmanita cubre ampliamente el fondo del cauce, extendiéndose aguas arriba. Esto demuestra que anteriormente fluyó un importante caudal de aguas fuertemente contaminadas procedentes de la balsa de gossan, que invadieron parte del cauce del río Odiel aguas arriba de la confluencia, permitiendo la precipitación abundante de schwertmanita.

\subsubsection{Cartografía del agua del río en relación con la acidez (pH)}

Aguas arriba del Puente de los Cinco Ojos, el río Odiel, relativamente limpio, recibe aguas intensamente contaminadas procedentes de la balsa de gossan de las minas de Río Tinto, haciendo que el pH del agua descienda bruscamente desde 7-6 hasta 3 .

Una vez identificadas las zonas del río en las que influyen espectralmente en el agua la vegetación y el fondo del río, se puede afrontar la identificación de los rasgos espectrales relacionados con el pH del agua (Figura 5.8).

Las imágenes Hymap de 2008 generan mapas de pH en el agua sólo si se usan en la secuencia de tratamiento digital las zonas identificadas previamente como agua profunda (Figura 5.8A). Los espectros de agua menos contaminada ( $\mathrm{pH}$ 6) en imágenes Hymap (Figura 5.9), que aparece aguas arriba de la confluencia del río Odiel con el tributario que drena aguas muy contaminadas, muestran una reflectancia generalmente alta, con un máximo en los $0.63 \mu \mathrm{m}$, que desciende progresivamente hacia longitudes de onda más largas, hasta $1 \mu \mathrm{m}$. Esta tendencia espectral coincide con la observada en las aguas con pH básico a la entrada del estuario (Figura 5.9). Las aguas con acidez intermedia ( $\mathrm{pH}$ 4) muestran un espectro con reflectancia global menor, y el mismo máximo en $0.63 \mu \mathrm{m}$, que desciende suavemente hacia longitudes de onda más largas.

Las aguas más ácidas ( $\mathrm{pH}$ 3) presentan un espectro con una reflectancia global baja y una clara influencia de la vegetación. Estas aguas ácidas se restringen a zonas del río 
donde el agua está parcialmente estancada (Figura 5.8B). Se dan cambios abruptos de pH a distancias muy cortas, de decenas de centímetros.

\subsubsection{EL CURSO MEDIO SUPERIOR (PUENTE EN LA CARRETERA DE CALAÑAS- VALVERDE DEL CAMINO)}

En la sección del cruce de la carretera de Valverde del Camino a Calañas el río sigue un trazo rectilíneo (Figura 5.10). En 2009 aparecen expuestas a la atmósfera amplias zonas inundadas en 2008, por el descenso del caudal de 2008 a 2009, que se cubren de sulfatos hidratados. En 2008 las barras fluviales están cubiertas principalmente por goethita, rodeadas por bandas de schwertmanita (Figura 5.10A), mientras que en 2009 las mismas barras fluviales aparecen cubiertas por schwertmanita, y ocasionalmente por goethita en las partes más altas. En 2009 la presencia de copiapita rodeando las barras es mayor que en 2008. Asimismo, la copiapita cubre algunas pequeñas superficies del cauce que normalmente están cubiertas por agua (Figura 5.10B, círculos amarillos).

\subsubsection{LAS MINAS EN LA ORILLA DEL RIO (SOTIEL)}

En el tramo del río que pasa por la mina de Sotiel hay vuelos Hymap correspondientes a tres años: 2005, 2008 y 2009. El verano de 2005 es muy caluroso y seco (Figura 5.1), comparado con un verano cálido en 2008 y ligeramente más cálido en 2009. La humedad fue normal tanto en 2008 como en 2009. El desarrollo de costras de minerales precipitados a partir de aguas ácidas sobre los sedimentos del río responde a una oxidación intensa en 2005, con aumento de las áreas cubiertas por sulfatos de hierro comparativamente más hidratados en 2008 y 2009.

Las asociaciones de minerales precipitados sobre los sedimentos en el muy caluroso verano de 2005, presentan el mayor grado de oxidación de la serie de datos estudiados. Se aprecia una evolución mineralógica controlada por la distancia a la escombrera mayor a orillas del río Odiel, la fuente de contaminación más intensa. En la zona septentrional en las proximidades de la escombrera mayor, las barras fluviales están rodeadas por jarosita, con goethita en las partes altas (Figura 5.11A, círculos verdes y rojos). La schwertmanita está casi ausente en esta zona septentrional.

La distribución de minerales en las costras cambia aguas abajo, donde las barras aparecen cubiertas por jarosita, goethita y schwertmanita (Figura 5.11A, círculos 
magenta y añil) en 2005. También aparecen copiapita en las zonas más hidratadas (Figura 5.11A, círculos naranjas).

En el verano de 2008, cálido y muy húmedo (Figura 5.1), además de las intensas lluvias de la primavera anterior (Figura 5.6) y al consiguiente aumento del nivel de agua del río, la oxidación de las costras de precipitados sobre los sedimentos es menor que en 2005. Los minerales dominantes que cubren las barras fluviales son jarosita $\mathrm{y}$ schwertmanita (Figura 5.11B). La goethita es escasa en la zona norte y más abundante aguas abajo (Figura 5.11B, círculos magentas).

El verano de 2009 es muy cálido y muy seco (Figura 5.1), y el nivel del agua del río es más bajo que en 2008. Las costras minerales que cubren los sedimentos están ligeramente más oxidadas, con mayor presencia de goethita en las partes altas de las barras fluviales (Figura 5.11C, círculo amarillo). También, en 2009 hay mayor presencia de minerales hidratados en pequeñas superficies fangosas, que en 2008 estaban inundadas por el agua (Figura 5.11C, círculos magenta).

\subsubsection{EL EJEMPLO DE LA TÍPICA RUPTURA DE PENDIENTE (PRESA AL SUR DE SOTIEL)}

Aguas abajo de la mina de Sotiel, hay una presa que atraviesa el río y actúa como ruptura de pendiente. Aguas abajo, hay una extensión amplia cubierta por costras de sulfatos hidratados en verano, fácilmente cartografiable con imágenes Hymap, cuando desciende el nivel del agua del río y el clima es suficientemente caluroso. Este punto del río proporciona el típico ejemplo en que el agua se agita al rebasar la pared, aumenta el oxígeno disuelto en agua, y por tanto la capacidad de oxidación. La presa se sitúa a la entrada de un meandro apretado, que aloja barras bien desarrolladas con sedimentos bien diferenciados según su tamaño de grano.

El año 2005 fue muy seco y muy caluroso (Figura 5.1). Los sedimentos del río aparecen cubiertos principalmente por jarosita, que se sustituye progresivamente por goethita aguas abajo (Figura 5.12A, círculos rojo y azul). Las costras de schwertmanita son escasas en el norte y más abundantes hacia el sur, cubriendo zonas húmedas acompañadas de copiapita (Figura 5.12A, círculo amarillo). El nivel del agua del río sube en 2008, un verano cálido y muy húmedo. Durante 2008, algunas de las barras emergidas en 2005 se inundan (Figura 5.12B, círculo rojo). Los episodios aislados y anómalos de lluvias abundantes en la primavera de 2008 aumentan el caudal del río y 
influyen en la distribución de sedimentos en el verano de 2008 (Figura 5.6) y las costras superpuestas de precipitados. La schwertmanita cubre homogéneamente amplias superficies de las barras fluviales (Figura 5.12B, círculo azul). En 2009, un verano muy cálido y con humedad normal (Figura 5.1.), la distribución de las costras de sulfatos de hierro precipitados sobre los sedimentos es similar a 2008. Destaca el aumento en la variedad de minerales hidratados en pequeñas áreas húmedas situadas aguas abajo de puntos de ruptura de pendiente en el río. También, la presencia ocasional de minerales comparativamente más hidratados que en 2008 (Figura 5.12C, círculos amarillos, verdes y magenta).

\subsubsection{EL CURSO MEDIO ENCAJADO CON TRAYECTORIA LINEAL (FUENTE DE LA CORCHA)}

En esta sección el río tiene un trazo rectilíneo y tiene gran capacidad de transporte, como demuestra el gran tamaño de los cantos en los sedimentos fluviales. El nivel de agua del río, así como la posición y el tamaño de las barras, son similares en 2008 y 2009, a diferencia de los tramos del río anteriores.

Las barras fluviales están cubiertas por goethita y schwertmanita, con la goethita cubriendo las partes altas de las barras (Figuras 5.13A y 5.13B). En 2008, la goethita y la schwertmanita son los minerales predominantes que cubren las barras (Figura 5.13A). En 2009, el grado medio de oxidación de las barras es similar al año anterior. Sin embargo, en 2009 aparecen áreas cubiertas por copiapita rodeando las barras y en partes estrechas del cauce en las que el flujo de agua es más lento (Figura 5.13B, círculos azules). También, en las terrazas que hay a lo largo de los márgenes de la llanura aluvial, se observa un mayor grado de oxidación en 2009 que en 2008.

\subsubsection{LA ENTRADA AL ESTUARIO (GIBRALEÓN)}

Esta sección del río tiene $15 \mathrm{~km}$ de longitud y es relativamente recta. Abarca un área comprendida entre la confluencia de los ríos Odiel y Oranque y la entrada en las marismas del estuario (Figura 5.14A). El río Odiel, contaminado, recibe las aguas también contaminadas del río Oranque.

Cuando el río se acerca al estuario, las imágenes Hymap revelan en los sedimentos del río el descenso progresivo del tamaño de grano dominante en las barras fluviales, al perder capacidad de transporte (Figura 5.14). Aguas arriba predominan las barras con cantos, seguidas aguas abajo de barras con gravas y arenas. A la entrada al estuario, 
bajo la influencia de las mareas, el canal se ensancha, y los sedimentos tienen tamaño de grano fino, barros y limos. Aquí, el agua marina con $\mathrm{pH}$ básico y cloruros disueltos, neutraliza la acidez del agua del río. La precipitación de sulfatos de hierro se sustituye por cloruros.

Hay un descenso significativo del caudal de 2008 a 2009 que da lugar a la exposición a la atmósfera de áreas que estaban inundadas en 2008 (Figura 5.14A). La posición y geometría de las barras es similar en los dos años, y los principales cambios se restringen a las superficies expuestas por el descenso del nivel del agua en 2009.

En 2008, en el área de cantos (Figura 5.14C y Figura 5.14D), aparecen en el cauce barras bien desarrolladas y delimitadas, con un canal estrecho y sinuoso. Las barras están cubiertas principalmente por costras de schwertmanita y goethita. La schwertmanita cubre uniformemente la mayor parte de las barras (Figura 5.14C, círculo verde), mientras que la goethita aparece como parches en las partes altas de las barras (Figura 5.14C, círculos azules). En 2009 la schwertmanita sigue siendo el mineral de meteorización de pirita predominante que cubre los sedimentos fluviales (Figura 5.14D, círculo verde). Las áreas cubiertas por goethita disminuyen su extensión (Figura 5.14D, círculos azules). Aparecen bandas de copiapita rodeando las barras fluviales (Figura $5.14 \mathrm{D}$, círculos amarillos).

En el área de las arenas (Figuras 5.14A y Figura 5.14B) (Riaza et al., 2012a), las barras fluviales se desarrollan como cuerpos sedimentarios alargados y espectralmente homogéneos, cubiertos principalmente por goethita, tanto en 2008 como en 2009 (Figuras 5.14E y Figura 5.14F). La schwertmanita es más abundante en 2009 que en 2008, rodeando las barras. En cambio, la goethita disminuye su extensión en 2009, permaneciendo en las partes altas de las barras (Figuras 5.14E y 5.14F, círculos azules). El descenso del nivel del agua del río hace que aparezcan amplias áreas emergidas en 2009 que estaban inundadas en 2008, cubiertas por lodos diagnosticados como copiapita (Figura 5.14F, círculos amarillos).

El área de canales y lodos (Figuras 5.14A y Figura 5.14B) (Riaza et al., 2012a) se sitúa cerca del estuario, y las mareas influyen en la geoquímica de las costras de sulfatos y en la geomorfología de los sedimentos fluviales (Riaza et al., 2012a). La capacidad de transporte del río disminuye, y se limita sólo a materiales finos en suspensión, que sedimentan como lodos. En 2008, las barras fluviales se disponen aisladamente en los meandros del cauce. Los canales de agua y las amplias superficies de lodos, que ocupan 
casi la anchura completa del cauce, discurren entre barras alternantes lingoidales de extensión reducida. Los lodos son abundantes, y los sedimentos de grano más grueso quedan restringidos a las pequeñas barras de arena, con parches discontinuos de cantos en su parte alta. Los lodos están cubiertos uniformemente por costras de schwertmanita, la mineralogía dominante (Figura 5.14G, círculo verde). Los sedimentos de grano más grueso muestran costras con diagnósticos más oxidados, como la goethita (Figura 5.14G, círculos azules). En 2009 el área cubierta por lodos prácticamente desaparece, reducida a parches aislados rodeando las barras de arenas, y cubierta por costras de copiapita, prácticamente ausente en 2008 (Figura 5.14F, círculo amarillo). En 2009 el canal es más ancho cerca del estuario que en 2008, lo que contradice la tendencia aguas arriba, con superficie ocupada por el agua más extensa en 2008 que en 2009. La influencia de las mareas explica esta contradicción.

La mezcla del agua ácida del río con agua marina influye en la geoquímica de los precipitados a partir de aguas que drenan sulfuros mineros (Riaza et al., 2012a), neutralizando la acidez de las aguas. Las costras de sulfatos de hierro se reemplazan por sales marinas, como cloruros de potasio y magnesio, cuya respuesta espectral es similar. Por todo ello, la cartografía espectral de sedimentos fluviales y costras en estuarios ha de ser muy cuidadosa.

\subsection{CONCLUSIONES}

En el trabajo descrito se usa la espectroscopía de imágenes como herramienta cartográfica enfocada al seguimiento de la contaminación generada por los residuos mineros de sulfuros de hierro, tanto en minas abandonadas como en la red fluvial. La cartografía geológica de detalle en áreas relativamente pequeñas se basa en una espectroteca de referencia desarrollada en laboratorio, que recoge la secuencia de minerales que se desarrollan durante el proceso de meteorización de pirita. Los mapas elaborados con imágenes del sensor aeroportado Hymap o del sensor Hyperion embarcado en satélite, revelan procesos geológicos y geoquímicos complejos, como la geomorfología y la geoquímica, que se pueden seguir a lo largo del tiempo.

Este sistema se basa en la interpretación de series temporales de datos hiperespectrales mediante espectroscopía de imágenes. Esta técnica ha sido propuesta por expertos de ambientes con residuos mineros como adecuada para el seguimiento de espacios inaccesibles, como las balsas de residuos, si los vuelos tienen la frecuencia temporal conveniente. 
Los datos en bruto proporcionados por los sensores hiperespectrales requieren operaciones adecuadas de tratamiento antes de acometer la interpretación geológica. En este trabajo, se esboza la cadena de de tratamiento previo para transformar los datos en bruto en reflectancia. Las imágenes resultantes con datos de reflectancia pueden interpretarse usando espectrotecas de referencia.

La interpretación geológica de los datos hiperespectrales de teledetección requiere algoritmos específicos, capaces de tratar datos de alta dimensionalidad. En este trabajo se describen los métodos de tratamiento de imágenes para extraer información geológica, así como la secuencia de algoritmos empleada para producir mapas, tanto en las minas como en el cauce del río.

Se establece una rutina para la cartografía mineral mediante el análisis de datos hiperespectrales Hymap. Se reduce el ruido y la dimensionalidad de los datos mediante la creación de subescenas de las áreas diana mediante la aplicación sucesiva de máscaras y extracción de miembros espectralmente puros que sean representativos. La espectroteca de estos miembros extremos se diagnostica mediante una espectroteca de referencia desarrollada en laboratorio.

Las espectrotecas de referencia sirven para confirmar el grado de oxidación o hidratación de las mezclas minerales. Además, ayudan a establecer evaluaciones estadísticas de estimaciones cuantitativas de diagnósticos minerales, que se establecen mediante la espectroteca de referencia con varios algoritmos. Las variaciones en estas estimaciones cuantitativas enriquecen el conocimiento de la disposición espacial de la contaminación. Se pueden evitar muchos diagnósticos mineralógicos erróneos teniendo en cuenta la evolución geoquímica de las sustancias minerales en el contexto geológico en el que se desarrollan.

El clima es un factor decisivo en el control de la evolución mineralógica de los productos de la meteorización de la pirita que cubren los sedimentos del río y los residuos mineros. Los mapas elaborados con tratamiento de imágenes hiperespectrales Hymap muestran las diversas tendencias en la meteorización de las balsas de lodos y de las escombreras mineras. Las escombreras de las minas completamente abandonadas y las orillas del río afectadas por el drenaje ácido de mina, pueden registrar los efectos de cambios climáticos a largo plazo. Para este propósito, los datos de teledetección hiperespectral deberían tomarse en momentos ideales para observar cambios de humedad y temperatura. 
Las zonas mineras que se encuentran en proceso de rehabilitación experimentan cambios en su superficie, cartografiables mediante espectroscopía de imágenes. Las superficies de las balsas de cenizas oxidadas, y de las balsas de lodos hidratados pierden su diversidad espectral y adquieren una respuesta espectral uniforme por la retirada de residuos y el movimiento de maquinaria.

Los mapas realizados a partir de imágenes hiperespectrales Hymap en las escombreras mineras muestran que la geomorfología controla la tendencia mineralógica de las costras desarrolladas sobre los fragmentos de las rocas. Las escombreras desarrollan un relieve en terrazas superpuestas. Las superficies planas muestran la respuesta espectral de minerales oxidados, como goethita, mientras que el espectro de las pendientes circundantes muestra minerales comparativamente más hidratados, principalmente schwertmannita. Las planicies que hay a pie de las escombreras canalizan corrientes de agua durante episodios lluviosos, y aparecen cubiertas por sulfatos hidratados, como copiapita.

Las imágenes Hymap pueden usarse para mostrar eficazmente la evolución progresiva de los minerales que aparecen sobre superficies geomorfológicamente identificables en las escombreras y a lo largo del cauce del río. Esto confirma cambios en la temperatura, humedad y precipitación registrados por las estaciones meteorológicas locales. La mayoría de las áreas cartografiadas en las imágenes como espectralmente distinguibles se identificaron con una espectroteca de referencia. Las observaciones y espectros de campo confirman las tendencias registradas en los datos multitemporales Hymap.

La cartografía de sustancias contaminantes en el río mediante imágenes hiperespectrales presenta varios desafíos. La descripción de la contaminación por residuos mineros a lo largo del río comienza por la cartografía de sedimentos fluviales y la localización de puntos críticos para la observación de la contaminación, ambos fuertemente controlados por la microgeomorfología del río y por la sedimentología. Una de las tareas más arduas es aislar y definir el área del canal de agua principal y los secundarios, para evitar la interpretación errónea de otras características de las superficies relacionadas con la contaminación. Así, las aguas ácidas se pueden confundir espectralmente con varios sulfatos hidratados de hierro típicos de la oxidación de piritas.

Una vez cartografiado el mapa general del río con un mapa general de sedimentos, el siguiente tratamiento de imágenes en subescenas definidas por cambios en los 
sedimentos, revelan desviaciones en los espectros del mapa general. La litología, el tamaño de grano y la geomorfología del río son los principales factores que controlan los sedimentos fluviales cartografiados. Las mayores áreas de costras de sulfatos se desarrollan a partir de los puntos de ruptura de la pendiente. Estos puntos se usan como indicadores para el estudio de la evolución mineralógica relacionada con cambios estacionales y climáticos.

El borde del agua, las áreas de depósito de sedimentos más finos, el grado de humedad, el lodo, la cobertera vegetal verde o seca, las aguas muy poco profundas con vegetación flotante y la influencia espectral del fondo del río son las zonas más críticas para la cartografía de los productos de la contaminación, tanto de las aguas ácidas fluviales como de las aguas marinas. Los sulfatos de hierro hidratados que precipitan a partir de aguas ácidas pueden confundirse espectralmente con el cloruro de potasio y magnesio (carnalita), que precipitan de agua salada. Cuando aparecen eflorescencias de halita (cloruro de sodio), que es espectralmente plana, los precipitados del agua salada son difíciles de detectar. La disminución de la acidez se puede detectar mejor por la ausencia de las típicas costras de sulfatos de hierro y de lodos piríticos de color amarillo intenso.

La cartografía de la calidad del agua se dificulta por la presencia de vegetación, seca o verde, enraizada o flotante, en los sedimentos adyacentes. Los rasgos espectrales del agua ácida en espectros de campo revela la influencia espectral de la vegetación verde. En este estudio se ha encontrado que la mezcla del agua marina con el agua dulce provoca notables cambios espectrales relacionados con la química del agua. Concretamente, el agua ácida se neutraliza por el agua marina alcalina, con alto contenido en iones. La influencia del agua salada provoca la disminución de la reflectancia global y la aparición de trazas espectrales de agua turbia en el intervalo de longitudes de onda del infrarrojo cercano con longitudes de onda más largas.

La espectroscopía de imágenes ha demostrado ser una técnica adecuada para cartografiar el pH del agua, tanto en balsas de agua mineras como en ríos contaminados. La respuesta espectral del agua ácida se ha comprobado con éxito en el punto en el que el río Odiel recibe los aportes de aguas ácidas contaminadas, tanto en las imágenes Hymap como en los espectros de campo. Los mapas generados en este estudio muestran satisfactoriamente los parámetros de la dinámica del río relacionados con la estimación de la intensidad de la contaminación o acidez del agua, tales como la 
profundidad del agua, la presencia de vegetación y la transparencia del agua. La microgeomorfología del río es crítica para localizar los remansos de agua ácida espectralmente identificables detrás de los puntos de ruptura de pendiente.

Los mapas elaborados con imágenes hiperespectrales, tanto en aeroportados o de satélite, son las principales herramientas para describir el estado de sustancias contaminantes en regiones fuertemente alteradas por la minería de sulfuros de hierro, tanto en las zonas mineras como en los cauces fluviales. El trabajo desarrollado hasta ahora es parte de un estudio más amplio cuyo objetivo es desarrollar un sistema de seguimiento que proporcione predicciones en las estimaciones potenciales de calidad de agua, y que las entidades administrativas puedan incorporar a sus procedimientos operativos de seguimiento ambiental más adelante. 


\section{REFERENCES}

AEMET (Agencia Estatal de Meteorología, Spain), Resumen Anual Climatológico de los años 2004, 2005, 2006, 2007, 2008 y 2009. www.aemet.es

ALMODOVAR, R., SAEZ, R., PONS, J.M., MAESTRE, A., TOSCANO, M. and PASCUAL, E., 1997, Geology and genesis of the Aznalcóllar massive sulphide deposits, Iberian Pyrite Belt, Spain. Mineralium Deposita 33, 1-2: 111-136.

ALPERS, C.N., NORDSTROM, D.K. and SPITZLEY, J., 2003, Extreme acid mine drainage from a pyritic massive sulfide deposit: the Iron Mountain endmember. In: JAMBOR, J.L., BLOWES, D.W. and RITCHIE, A.I.M. (Eds.), Environmental Aspects of Mine-Wastes. Mineralogical Association of Canada: 407-430.

ANDERSON, J.E. and ROBBINS, E.I., 1998, Spectral reflectance and detection of ironoxide precipitates associated with acidic mine drainage, Photogrammetric Engineering and Remote Sensing 64, 1201-1208.

ASD, 2006, FieldSpecR 3 User Manual, ASD Document 600540 Rev. F, Analytical Spectral Devices, Inc. www.asdi.com

BERGER, A.R. and IAMS, W.J., 1996, Geoindicators: Assessing rapid environmental changes in earth systems. A.A. Balkema.

BIGHAM, J.M., SCHWERTMANN, U., TRAINA, S.J., WINLAND, R.L. and WOLF, M., 1996, Geochimica et Cosmochimica Acta, 60-12, 2111-2121.

BOARDMAN, J.W. and KRUSE, F.A., 1994, Automated spectral analysis: a geological example using AVIRIS data, north Grapevine Mountains, Nevada: in Proceedings, ERIM Tenth Thematic Conference on Geologic Remote Sensing, Environmental Research Institute of Michigan, Ann Arbor, MI, I: 407-418.

BOARDMAN, J.W., KRUSE, F.A., and GREEN, R.O., 1995, Mapping target signatures via partial unmixing of AVIRIS data: in Summaries, Fifth JPL Airborne Earth Science Workshop, JPL Publication 95-1, v. 1, 23-26. 
BOARDMAN, J.W., 1993, Automated spectral unmixing of AVIRIS data using convex geometry concepts: in Summaries, Fourth JPL Airborne Geoscience Workshop, JPL Publication 93-26, v. 1, 11 - 14.

BRANDO, V.E. and DEKKER, A.G., 2003, Satellite hyperspectral remote sensing for estimating estuarine and coastal water quality, IEEE Transactions on Geoscience and Remote Sensing 41-6, 1378-1387.

BUURMAN, P., 1975, In vitro weathering products of pyrite. Geologie Mïnvouw, 54, 101-105.

BUZZI, J., GARCIA-MELENDEZ, E. and RIAZA, A., 2009, Cartografía con espectroscopía de imágenes de productos de oxidación de piritas en la mina de Sotiel (Huelva, España) con el sensor Hymap, Segundas Jornadas de Investigadores en formación en Ciencias de la Tierra, Madrid, 10-13 Noviembre 2009, 83.

BUZZI, J., RIAZA, A. and GARCÍA-MELÉNDEZ, E., 2010a, Seguimiento de minas en rehabilitación mediante imágenes hiperespectrales Hymap (Sotiel-Almagrera): datos 2005-2009, III Jornadas de Investigadores en Formación en Ciencias de la Tierra, 1819 Noviembre 2010, Madrid.

BUZZI, J., RIAZA, A., GARCÍA-MELÉNDEZ, E., WEIDE, S. and BACHMANN, M., 2010b, Cartografía con espectroscopía de imágenes de productos de oxidación piritas en residuos de la mina de Sotiel (Huelva, España) con el sensor Hymap, I Congreso Estatal de Sostenibilidad, Rivas Vaciamadrid, 11-13 Marzo 2010, in press.

BUZZI, J., RIAZA, A., GARCÍA-MELÉNDEZ, CARRÈRE, V. and BACHMANN, M., 2011a, Aplicación de modelos Gaussianos modificados a datos hiperespectrales de una zona contaminada por drenaje ácido. Caso del río Odiel (Huelva, España). 2011, XIV Congreso de la Asociación Española de Teledetección, Mieres, 21-23 Septiembre 2011, 285-288.

BUZZI, J., RIAZA, A., GARCÍA-MELÉNDEZ, CARRÈRE, V. and BACHMANN, M., 2011b, Aplicación de modelos Gaussianos modificados a datos hiperespectrales de una zona contaminada por drenaje ácido. Caso del río Odiel (Huelva, España). IV Jornadas de Investigadores en Formación en Ciencias de la Tierra, 1-2 Diciembre, Madrid, p 51.

BUZZI, J., CARRÈRE, V., RIAZA, A., GARCÍA-MELÉNDEZ, E. and BACHMANN, M., 2011c, Modified gaussian modelization applied to hyperspectrtal data in an AMD- 
contaminated area. Case of Odiel river (Huelva, SW Spain), $7^{\text {th }}$ EARSeL Workshop on Imaging Spectroscopy, Edinburgh, Scotland, $11^{\text {th }}-13^{\text {th }}$ April 2011, in press.

BUZZI, J., RIAZA, A., GARCÍA-MELÉNDEZ, E. and HOLZWARTH, S., 2012, Change detection in sediments of a river affected by acid mine drainage using airborne hyperspectral Hymap data (River odiel, SW Spain), $4^{\text {th }}$ EARSeL Workshop on Remote Sensing and Geology, $24^{\text {th }}-25^{\text {th }}$ May 2012, Mykonos island (Greece), in press.

CÁNOVAS, C.R., OLÍAS, M., NIETO, J.M., SARMIENTO, A. and CERON, J.C., 2007, Hydrogeochemical characteristics of the Tinto and Odiel Rivers (SW Spain).Factors controlling metal contents, Science of the Total Environment 373, 363-382.

CLARK, R.N., VANCE, S., LIVO, K.E. and GREEN, R.O., 1998, Mineral mapping with imaging spectroscopy: the ray mine, AZ. In: GREEN, R.O. (Ed.) Summaries of the $7^{\text {th }}$ annual JPL airborne earth science workshop, $12^{\text {th }}-14^{\text {th }}$ Jan 2004. JPL Publication, 9721, pp 67-76.

CLARK, R.N., GALLAGHER, A.J., and SWAYZE, G.A., 1990, Material absorption band depth mapping of imaging spectrometer data using the complete band shape leastsquares algorithm simultaneously fit to multiple spectral features from multiple materials: in Proceedings of the Third Airborne Visible/Infrared Imaging Spectrometer (AVIRIS) Workshop, JPL Publication 90-54, pp. 176 - 186.

CLARK, R.N., SWAYZE, G.E., WISE, R., LIVO, E., HOEFEN, T., KOKALY, R. and SUTLEY, S.J., 2007, “USGS digital spectral library”, Digital Data Series 231, 2007.

COCKS, T., JENSSEN, R., STEWART, A., WILSON, I. and SHIELDS, T., 1998, The Hymap $^{\mathrm{TM}}$ Airborne Hyperspectral Sensor: The system, calibration and performance. Proceedings $1^{\text {st }}$ EARSEL Workshop on Imaging Spectroscopy, Zürich, October 1998.

COLLINSON, J.D., 1978, reedited 1986, Alluvial sediments, in Reading, H.G., ed., In Sedimentary Environment and Facies, pp. 63-282, Blackwell Scientific Publications, Oxford, $615 \mathrm{p}$.

CROWLEY, J.K., WILLIAMS, D.E., HAMMARSTROM, J.M., PIATAK, N., CHOU, I-M. and MARS, J.C., 2003, Spectral reflectance properties (0.4-2.5 $\mu \mathrm{m})$ of secondary Feoxide, Fe-hydroxide, and Fe-sulphate-hydrate minerals associated with sulphidebearing mine wastes. Geochemistry: Exploration, Environment, Analysis, 3- 3, 219228(10). 
DEKKER, H.J. and HOOGENBOOM, A.G., 1996, Predictive modelling of AVIRIS performance over inland waters, Sixth Annual JPL Airborne Earth Science Workshop, JPL Publication 96-4 1, 83-92.

FARRAND W.H. and HARSANYI, J.C., 1995, Mineralogic Variations in Fluvial Sediments Contaminated by Mine Tailings as Determined From AVIRIS Data, Coeur d'Aldene River, Idaho. Paper presented at AVIRIS Workshop: 47-50.

FELDE, G.W., ANDERSON, G.P., COOLEY, T.W., MATTHEW, M.W., ADLERGOLDEN, S.M., BERK, A. and LEE, J., 2003 Analysis of Hyperion data with the FLAASH atmospheric correction algorithm. Paper presented at Geoscience and Remote Sensing Symposium 2003, San Francisco, IGARSS '03 20-1: 90-92.

FONT TULLOT, I., 1983, Climatología de España y Portugal (Climatology of Spain and Portugal). Instituto Nacional de Meteorología Publications.

GARCÍA-HARO, F.J., SOMMER, S. and KEMPER, T., 2005, A new tool for variable multiple endmember spectral mixture analysis (VMESMA), International Journal of Remote Sensing, 26-10, 2135-3162.

GOETZ, A.F.H., VANE, G., SOLOMON, J.E. and ROCK, B.N., 1985, Imaging spectrometry for earth remote sensing: Science, v. 228, pp. 1147 - 1153.

GOETZ, A.F.H., FERRI, M., KINDEL, B. and ZHENG, QU., 2002, Atmospheric correction of Hyperion data and techniques for dynamic scene correction. Paper presented at Geoscience and Remote Sensing Symposium 2002, Toronto, IGARSS '02. IEEE International, IGARSS 2002 3: 1408-1410. DOI: 10.1109/IGARSS.2002.1026132.

HAMMARSTROM, J.M., SEAL II, R.R., MEIER, A.L. and KORNFELD, J.M., 2005, Secondary sulphate minerals associated with acid mine drainage in the eastern US: recycling of metals and acidity in surficial environments. Chemical Geology, 6o(11), pp. 1193-1202.

HUBBARD, B.E. and CROWLEY, J.K., 2005, Mineral mapping on the Chilean-Bolivian Altiplano using co-orbital ALI, ASTER and Hyperion imagery, Data dimensionality issues and solutions. Remote Sensing of Environment 99:173-186.

HUNT, G.R. and SALISBURY, J.W., 1976. Visible and near infrared spectra of minerals and rocks: XI. Sedimentary rocks. Modern Geology, 5 pp. 211-217. 
KEMPER, T. and SOMMER, S., 2003, Mapping and monitoring of residual heavy metal contamination and acidification risk after the Aznalcóllar mining accident (Andalucía, Spain) using field and airborne hyperspectral data, Proceedings $3^{\text {rd }}$ EARSeL Workshop on Imaging Spectroscopy, Herrsching, Germany, 13-16 $6^{\text {th }}$ May 2003, 333-343.

KRUSE, F.A., LEBKOFF, A.B., BOARDMAN, J.B., HEIDEBRECHT, K.B., SHAPIRO, A.T., BARLOON, P.J. and GOETZ, A.F.H., 1993, The Spectral Imaging Processing System (SIPS) - Interactive Visualization and Analysis of Imaging Spectrometer Data. Remote Sensing of Environment, 44:145-163.

JUPP, D.L.B., 2001, Discussion around Hyperion Data, CSIRO Office of Space Science Applications, Earth Observation Centre: 1-9.

JUPP, D.L.B., DATT, B., LOVELL, J., CAMPBELL, S. and KING, E., 2002, Discussions around Hyperion Data: Background Notes for the Hyperion Data Users Workshop. CSIRO Earth Observation Centre 2002.

KRUSE, F.A., BOARDMAN, J.W. and LIVO, K.E., 2004, Using Hyperspectral Data for Urban Baseline Studies, 13th JPL Airborne Geoscience Workshop, JPL Publication o53 , $\mathrm{ftp}: / /$ popo.jpl.nasa.gov/pub/docs/workshops/o4_docs/KruseJPL2004_Boulder_Urban.pdf (checked July 2007).

KARASKA, M.A., HUGUENIN, R.L., BEACHAM, J.L., WANG, M.H., JENSEN, J.R. and KAUFMANN, R.S., 2004, AVIRIS Measurements of Chlorophyll, Suspended Minerals, Dissolved Organic Carbon, and Turbidity in the Neuse River, North Carolina, Photogrammetric Engineering \& Remote Sensing, 70-1, 125-133.

LEBLANC, M., MORALES, J.A., BORREGO, J. and ELBAZ-POULICHET, A., 2000, 4500 years old mining pollution in Southwestern Spain: Long-Term concerns for modern mining. Economic Geology 95: 655-672.

LÉVESQUE, J., SZEREDI, T., STAENZ, K., SINGHROY, V. and BOLTON, D., 1997, Spectral Unmixing for Monitoring Mine Tailings Site Rehabilitation, Copper Cliff Mine, Sudbury, Ontario. Paper presented at the Twelfth International Conference and Workshops on Applied Geologic Remote Sensing, Denver, Colorado, $17^{\text {th }}-19^{\text {th }}$ November 1997. 
MARS, J.C. and CROWLEY, J.K., 2003, Mapping mine wastes and analyzing areas affected by selenium-rich water runoff in southeast Idaho using AVIRIS imagery and digital elevation data. Remote Sensing of Environment 84-3:422-436.

MONTERO, I. and BRIMHALL, G., 2002, Multiplatform VIS/SWIR Hyperspectral Approach to the Study of Acid Mine Drainage from Abandoned Mines. Annual Meeting Geological Society of America, Denver, 2002.

MUNSELL COLOR CO., 1950 (revised 1990), Munsell Soil Color Charts (Baltimore, MD: Munsell Color, Macbecth Division of Kollmorgen Corporation).

NIETO, J.M., SARMIENTO, A., OLÍAS, M., CÁNOVAS, C.R., RIBA, I., KALMAN, J. and DELVALLS, A., 2007, Acid mine drainage pollution in the Tinto and Odiel rivers (Iberian Pyrite Belt, SW Spain) and bioavailability of the transported metals to the Huelva Estuary, Environment International, 33, 445-455.

NORDSTROM, D.K. and ALPERS, C.N., 1999, Geochemistry of acid mine waters. In: PLUMLEE, G.S. and LOGSDOM, M.J. (Eds.), The Environmental Geochemistry of Mineral Deposits. Part A: Processes, Techniques, and Health Issues. Reviews in Economic Geology, 6A: 133-160.

OLIAS, M., NIETO, J.M., SARMIENTO, A.M., CERÓN, J.C. and CANOVAS, C.R., 2004, Seasonal water quality variations in a river affected by acid mine drainage: the Odiel River (South West Spain). Science of the Total Environment 333, 1-3:267-281.

OLÍAS, M., CÁNOVAS, C.R., NIETO, J.M. and SARMIENTO, A., 2006, Evaluation of the dissolved contaminant load transported by the Tinto and Odiel rivers (SouthWest Spain), Applied Geochemistry 21, 1733-1749.

ONG, C. and CUDAHY, T., 2002, Deriving Quantitative Monitoring Data Related to Acid Drainage Using Multi-temporal Hyperspectral Data. Paper presented at the AVIRIS Workshop 2002.

ONG, C., CUDAHY, T.J. and SWAYZE, G., 2003, Predicting Acid Drainage Related Physicochemical Measurements Using Hyperspectral Data. $3^{\text {rd }}$ EARSeL Workshop on Imaging Spectroscopy, Herrsching, $13^{\text {th }}-16^{\text {th }}$ May 2003.

PANIAGUA, L., BACHMANN, M., FISCHER, C., KOOISTRA, L. and MÜLLER, A., 2009, Monitoring mining rehabilitation development according to methods derived 
from imaging spectroscopy, case study in the Sotiel-Migollas mine complex, southern Spain. Proceedings $6^{\text {th }}$ EARSeL Imaging Spectroscopy Workshop 2009 , March $16^{\text {th }}$ $19^{\text {th }}$ 2009, Tel Aviv (Israel), p. 3069.

PLUMLEE, G.S., 1999, The environmental geology of mineral deposits. Part A: Processes, Techniques, and Health Issues. Reviews in Economic Geology, 6A, 71-116.

RIAZA, A., C. ONG and A. MÜLLER, 2006, Dehydration And Oxidation Of Pyrite Mud And Potential Acid Mine Drainage Using Hyperspectral Dais 7915 Data (Aznalcóllar, Spain), ISPRS Mid-Term Symposium 2006 "Remote Sensing: From Pixels To Processes", Enschede, The Netherlands, $8^{\text {th }}-11^{\text {th }}$ May 2006, The International Archives of the Photogrammetry, Remote Sensing and Spatial Information Sciences, Vol. 34, Part XXX, ISSN: 1682-1750.

RIAZA, A., ONG, C. and MÜLLER, A., 2007, Pyrite mine wastes hyperspectral monitoring as a tool to detect Climate Change, Proceedings $10^{\text {th }}$ Intl. Symposium on Physical Measurements and Signatures in Remote Sensing, ISPMSRSo7, WG VII/1, March $12^{\text {th }}-14^{\text {th }}, 2007$, Davos, Switzerland, 228-233.

RIAZA, A. and MÜLLER, A., 2010, Hyperspectral Remote Sensing monitoring of Pyrite Mine Wastes: A record of climate variability (Pyrite Belt, Spain), Environmental Earth Sciences, 61-3, 575-594. DOI: 10.1007/s12665-009-0368-y.

RIAZA, A. and CARRERE, V., 2010, Monitoring of superficial contamination produced by massive sulphide mine waste along the Odiel River (Andalousia, Spain) using hyperspectral data, IGARSS 2009, $13^{\text {th }}-17^{\text {th }}$ July 2009, Cape Town (South Africa), Geoscience and Remote Sensing Symposium, 2009, IEEE International, IGARSS 2009, 3, III-1701-III-1704, ISBN: 978-1-4244-3394-0. $\quad$ DOI: 10.1109/IGARSS.2009.5417966.

RIAZA, A., J. BUZZI, E. GARCÍA-MELÉNDEZ, V. CARRÈRE and A. MÜLLER, 2011a, Monitoring the extent of contamination from acid mine drainage in the Iberian Pyrite Belt (SW Spain) using hyperspectral imagery, Remote Sensing, 2011, 3, 2166-2186; doi:10.3390/rs3102166.

RIAZA, A., GARCIA-MELENDEZ, E. and MUELLER, A., 2011b, Spectral identification of pyrite mud weathering products: a field and laboratory evaluation, International Journal of Remote Sensing, 32: 1, 185-208. DOI: 10.1080/01431160903439957. 
RIAZA, A., J. BUZZI, E. GARCÍA-MELÉNDEZ, V. CARRÈRE, A. SARMIENTO, A. and MÜLLER, 2012a, River acid mine drainage sink by coastal tides: sediment and water mapping through hyperspectral Hymap data, International Journal of Remote Sensing, 33:19, pp. 6163-6185, DOI:0.1080/01431161.2012.675454.

RIAZA，A., BUZZI，J., GARCÍA-MELÉNDEZ, E., VÁZQUEZ, I., BELLIDO, E., CARRÈRE, V. and MÜLLER, A. 2012b, Pyrite mine waste and water mapping using Hymap and Hyperion hyperspectral data, Environmental Earth Sciences, 66-7, 19571971. DOI 10.1007/s12665-011-1422-0.

RICHTER, R. and SCHLÄPFER, D., 2002, Geo-atmospheric processing of airborne imaging spectrometry data. Part 2: atmospheric/topographic correction. International Journal of Remote Sensing 23, 2631-2649.

RODRIGUEZ VIDAL, J., CÁCERES PURO, L. and RODRIGUEZ RAMIREZ, A., 1991, La red fluvial cuaternaria en el piedemonte de Sierra Morena occidental, Cuadernos Información Geográfica, 17:1-2, 37-45.

RSI, 2000, ENVI User's Guide. Research Systems Inc. Publications.

SALOMONS, W., 1995, Environmental impact of metals derived from mining activities: processes, predictions, preventions. Journal of Geochemical Exploration, 52:1-2, 5-23.

SANCHEZ ESPAÑA, J., LOPEZ PAMO, E., SANTOFIMIA, E., ADUVIRE, O., REYES, J. and BARETTINO, D., 2005, Acid mine drainage in the Iberian Pyrite Belt (Odiel river watershed, Huelva, SW Spain): Geochemistry, mineralogy and environmental implications, Applied Geochemistry, 20, 1320-1356.

SARES, A., HAUFF, P.H.L., PETERS, D.C., COULTER, D.W., BIRD, D.A., HENDERSON III, F.B. and PROSH, E.C., 2003, Characterizing Sources of Acid Rock Drainage and Resulting Water Quality Impacts Using Hyperspectral Remote Sensing Examples from the Upper Arkansas River Basin, Colorado. Paper presented at the Geospatial Conference, December $7^{\text {th }}-9^{\text {th }}$ 2004, Atlanta (GA, USA).

SARMIENTO, A., OLÍAS, M., NIETO, J.M., CÁNOVAS, C.R. and GALVÁN, L., 2006, La degradación de la cuenca del río Odiel (Huelva, España) por drenaje ácido de mina (Huelva, España). V Congreso Ibero, Gestao e Planeamiento da Agua. Faro, Portugal. 
SARMIENTO, A.M., NIETO, J.M., OLÍAS, M. and CÁNOVAS, C.R., 2009, Hydrochemical characteristics and seasonal influence on the pollution by acid mine drainage in the Odiel river Basin (SW Spain), Applied Geochemistry 24, 697-714.

SCHLÄPFER, D. and RICHTER, R. 2002, Geo-atmospheric processing of airborne imaging spectrometry data. Part 1: parametric orthorectification. International Journal of Remote Sensing 23, 2609-2630.

SEAL II, R.R. and HAMMARSTROM, J.M., 2003, Geoenvironmental models of mineral deposits: examples from massive sulphide and gold deposits. In: JAMBOR, J.L., BLOWES, D.W. and RITCHIE, A.I.M., 2003, Environmental Aspects of MineWastes. Mineralogical Association of Canada: 11-51.

SHIH, T-Y., 2004, On the atmospheric correction for a Hyperion scene. Paper presented at $25^{\text {th }}$ Asian Conference \& $1^{\text {th }}$ Asian Space Conference on Remote Sensing, November 22 $\quad 2004,26^{\text {th }}, \quad$ Thailand: $1-4$. http://www.gisdevelopment.net/aars/acrs/2004/b hyper/acrs2004 b2010.asp

SINGER, P.C. and STUMM, W., 1970, Acidic mine drainage: the rate-determining step, Science, 167, 1121-1123.

SUNSHINE, J.M. and PIETERS, C.M., 1993, Estimating modal abundances from the spectra of natural and laboratory pyroxene mixtures using the Modified Gaussian Model. Journal of Geophysical Research, 98 (E5), 9075-9078.

SWAYZE, G.A., CLARK, R.N., PEARSON, R.M. and LIVO, K.E., 1996, Mapping Acid Generating Minerals at the California Gulch Superfund Site in Leadville, Colorado, using Imaging Spectroscopy. In: GREEN, R.O. (Ed.), JPL Publication 96-4

SWAYZE, G.A., CLARK, R.N., SMITH, K.S,, HAGEMAN, P.L., SUTLEY, S.J., PEARSON, R.M., RUST, G.S., BRIGGS, P.H., MEIER, A.L., SINGLETON, M.J. and ROTH, S., 1998, Using imaging spectroscopy to cost-effectively locate acid-generating minerals at mine sites: an example from the California Gulch Superfund Site. Paper presented at the Airborne Visible/Infrared Imaging Spectrometer (AVIRIS): 1998 JPL Airborne Geoscience Workshop, Leadville, Colorado, 1998

SWAYZE, G.A., SMITH, K.S., CLARK, R.N., SUTLEY, S.J., PEARSON, R.M., VANCE, J.S., HAGEMAN, PH.L., BRIGGS, P.H., MEIER, A.L., SINGLETON, M.J. and ROTH, 
S., 2000, Using imaging spectroscopy to map acidic mine waste. Environmental Science and Technology, 34, 47-54.

UNITED STATES GEOLOGICAL SURVEY (USGS), 2004, EO-1 User Guide, url://http://eo1.usgs.gov/dataproducts/faq.asp\#hyperion.

VAN DER MEER, F.D. and DE JONG, S.M. (Eds.), 2001, Imaging Spectrometry. Basic Principles and Prospective Applications. Kluwer Academic Publishers.

VELASCO, F., ALVARO, A., SUAREZ, A., HERRERO, J. and YUSTA, I., 2005, Mapping Fe-bearing sulphate minerals with short wave infrared (SWIR) spectral analysis at San Miguel mine environment, Iberian Pyrite Belt (SW Spain). Journal of Geochemical Exploration 87, 45-72.

VERA, J.A. (Ed.), 2004, Geología de España (Geology of Spain), SGE-IGME, Madrid.

VERPOORTER, C.V., CARRÈRE, V. and COMBE, J.-P., 2009, Sediment characterization in the intertidal zone of Bourgneuf Bay (France) using the Automated Modified Gaussian Model (AMGM). EGU General Assembly. Vienna, Austria.

ZABCIC, N., ONG, C., MÜLLER, A. and RIVARD, B., 2005, Mapping pH from airborne hyperspectral data at the Sotiel-Migollas mine; Calanas, Spain. Proceedings $4^{\text {th }}$ EARSeL Workshop on Imaging Spectroscopy 2005, 27 th $^{\text {th }} 9^{\text {th }}$ April 2005, Warsaw (Poland), 467-472.

ZABCIC, N., 2008, Derivation of $\mathrm{pH}$-values based on mineral abundances over pyrite mining areas with airborne by hyperspectral data (Hymap) of Sotiel Migollas mine complex. M.Sc. Thesis, University of Alberta 20o8, Canada, 154 pp. 
